\title{
Plant-pollinator networks in fragmented calcareous grasslands
}

\author{
Dissertation \\ to obtain the $\mathrm{Ph}$. D. degree \\ Ph. D. Program for Agricultural Sciences in Göttingen (PAG) \\ at the Faculty of Agricultural Sciences, \\ Georg-August-University Göttingen, Germany
}

presented by

Felipe Miguel Librán Embid

born in Montevideo, Uruguay

Göttingen, March 2021 
D7

$1^{\text {st }}$ supervisor: Prof. Dr. Teja Tscharntke $2^{\text {nd }}$ supervisor: Prof. Dr. Ingo Grass

Date of thesis submission: 8. June 2020

Date of oral examination: 22. July 2020 
"There is still a window of time. Nature can win if we give her a chance."

Dr. Jane Goodall 


\section{Contents}

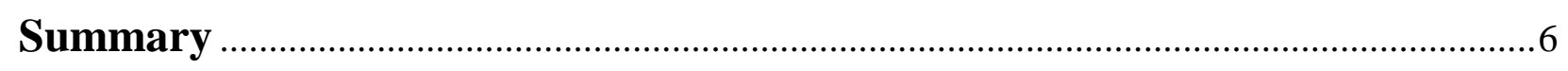

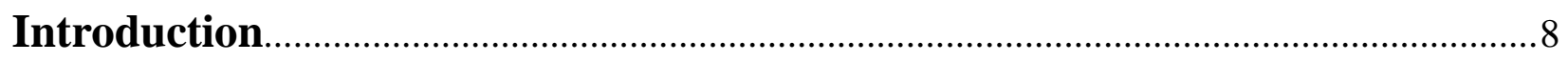

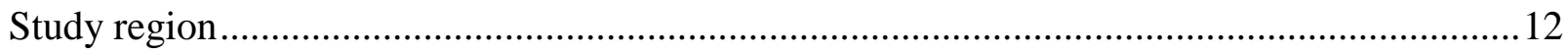

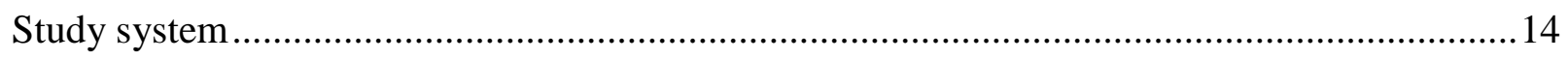

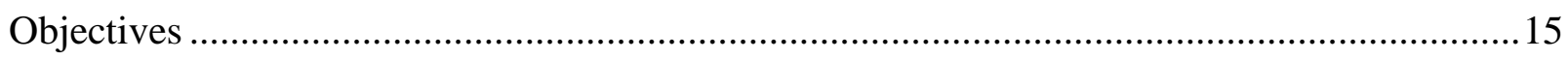

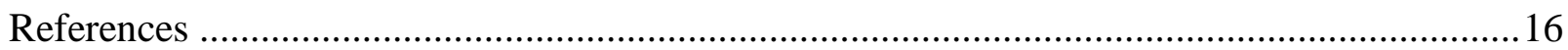

\section{Chapter 1 Unmanned aerial vehicles for biodiversity-friendly agricultural}

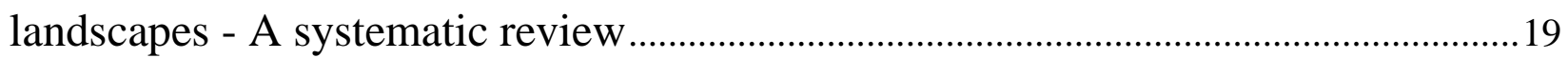

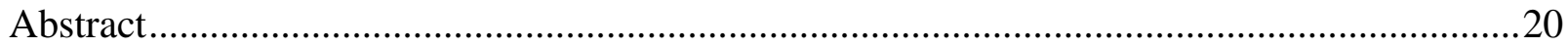

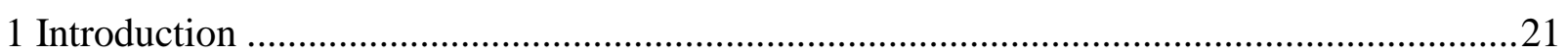

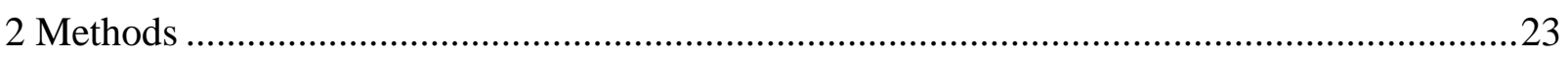

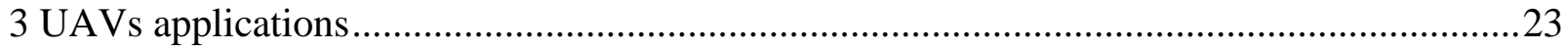

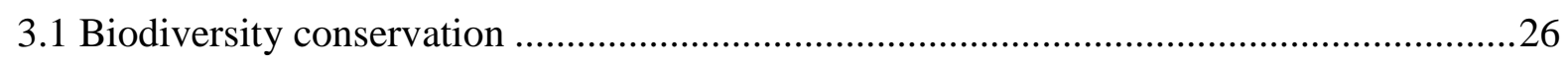

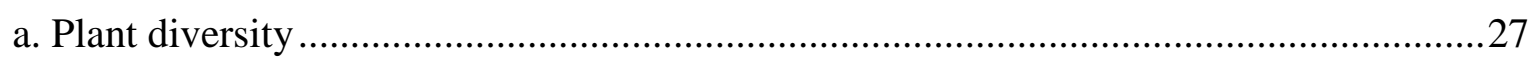

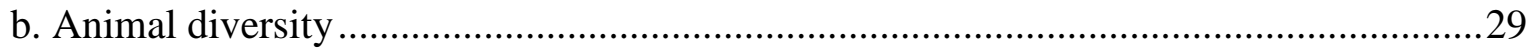

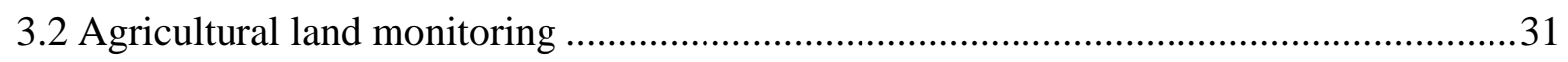

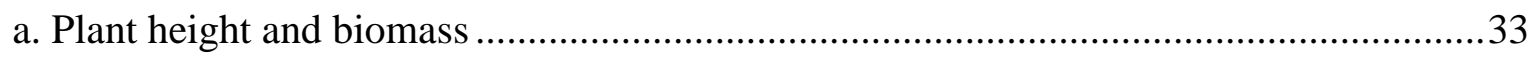

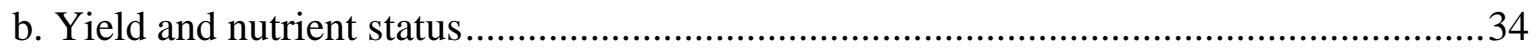

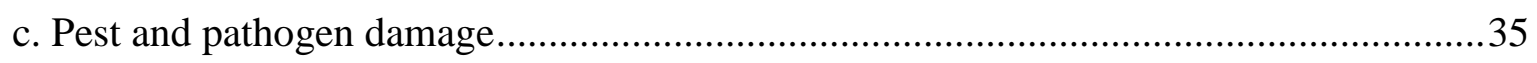

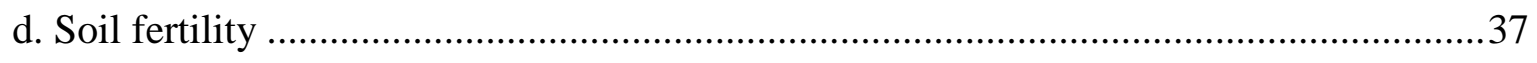

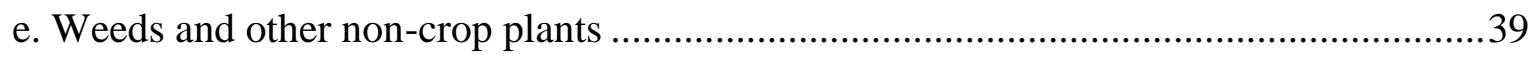

4 Perspectives on future research .................................................................................. 40

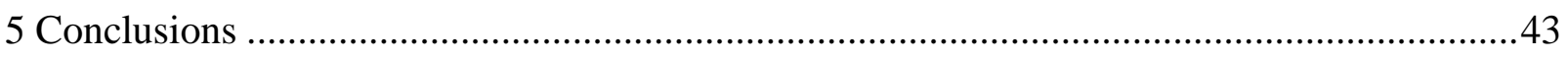

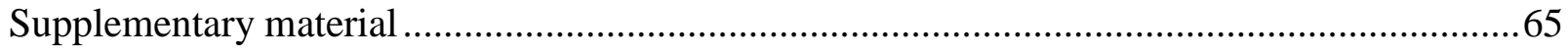


Chapter 2 A plant-pollinator metanetwork along a habitat fragmentation gradient

Abstract

Chapter 3 Pollination networks in fragmented landscapes are less specialised for

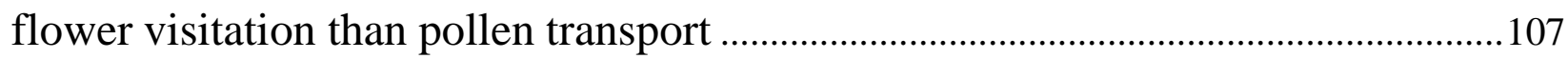

Abstract

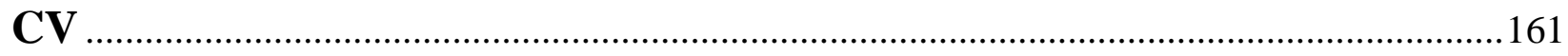

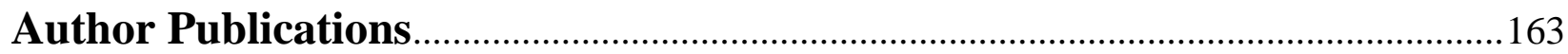

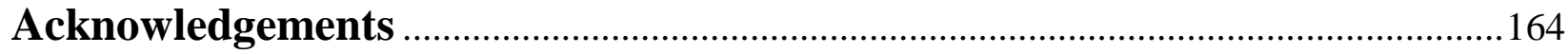




\section{Summary}

Understanding the dynamics of species interactions under the threats of habitat loss and fragmentation can be key to develop measures preventing further degradation of natural and agricultural systems. Agroecological knowledge and state of the art technologies can help to conciliate the often-discrepant objectives of biodiversity conservation and agricultural production. Specifically, information on the characteristics of plant-pollinator networks in agroecosystems can unveil the most efficient strategies to preserve ecosystem functionality and pollination services provision.

In chapter 1, I focused on the contributions of new technology to the objective of turning agricultural landscapes increasingly compatible with biodiversity. I reviewed the applications of unmanned aerial vehicles (UAVs) in ecology and precision agriculture. I 1) identified existing applications, 2) discussed limitations and advantages of the current technology, 3) highlighted knowledge gaps and 4) proposed new applications.

In chapter 2, I studied the characteristics of a plant-pollinator metanetwork of calcareous grasslands embedded in an agricultural matrix. I characterized and discussed the structural properties of the network that determine its stability and resilience to perturbations. Furthermore, I identified the traits of the most central nodes in the network. I found that the metanetwork was significantly more modular and less connected than expected by chance. This reflects the existence of many fragment-unique interactions and is an indication of poor metanetwork stability. I also demonstrated that habitat size and the diversity of land cover types in the surroundings of a grassland fragment are significant predictors of site centrality. Thus, these features can help to identify the most important fragments for metanetwork cohesiveness. Additionally, I found that the centrality of interactions depends on the pollinator size, species identity and also on the plant's habitat specialization.

In chapter 3, I compared plant-pollinator networks constructed with flower visitation data to networks constructed with pollen transport data. The level of specialization of pollen transport networks was higher than that of visitation networks, as half of the interactions in the visitation networks did not occur in the pollen transport networks. This highlights the fact that visitation does not necessarily imply pollen transport, and I discussed its implications for the conservation of pollination. Considering that high specialization is known to be associated with low stability in 
mutualistic networks, this result has important implications for conservation. According to these findings, traditional studies on plant-pollinator networks, based on visitation data, would overestimate the stability of pollination networks. Additionally, I identified that almost a third of the total number of interactions found are difficult to spot given their low frequency, occurring only in the pollen transport networks. Finally, I found positive effects of landscape diversity on the total number and proportion of single-fragment interactions for pollen transport, but not for visitation networks.

In conclusion, the protection of large and small calcareous grasslands as well as the enhancement of landscape heterogeneity was found to be essential for the maintenance of the plant-pollinator metanetwork. Furthermore, the importance of interactions among habitat specialist plants and large-bodied generalist pollinators appeared to be fundamental to connect the plant-pollinator metanetwork. Nonetheless, small solitary bees and the habitat specialist butterfly Polyommatus coridon also played a central role for the plant-pollinator networks in calcareous grasslands. By identifying the most central plants, pollinators and interactions at the metacommunity level, the information reported in this work can inform tailored management measures to protect them. Among others, I suggest considering plant species' roles in the metanetwork when applying conservation measures, such as flower strips, and landscape coordination among farmers to increase crop diversification. Moreover, I showed the great potential of UAVs to contribute to such conservation measures and to biodiversity management in agricultural landscapes. UAVs can assist in diverse tasks such as quantifying encroachment of calcareous grasslands and plant diversity monitoring. Additionally, they can contribute to farmer's cropland management and agri-environmental schemes surveillance by governmental agencies. 


\section{Introduction}

The 2020-2030 decade is critical to the fight against climate change and environmental degradation, as many no-return ecosystem limits are predicted to be reached (Dakos et al., 2019; Ge et al., 2019a). Avoiding environmental collapse is fundamental to protect all types of life on Earth including humankind (Breyer et al., 2017) and can only be achieved by operating within the planetary biophysical boundaries (Rockström et al., 2009). The solutions to this challenges are certainly multidimensional and interdisciplinary, encompassing complex questions in the fields of philosophy, economy and ecology, among many others (Reid and Mooney, 2016).

This thesis aims to contribute to the solution of one of the main challenges on the ecological side of the problem: reconciling agricultural production and biological conservation (Egli et al., 2018). How do ecological networks respond to the pressures of habitat fragmentation in agricultural landscapes? Can we design agricultural landscapes that cannot just conserve biodiversity but also benefit from it?

The development of novel approaches and technologies is fundamental, as we cannot expect to solve new problems using old methods. Developments from one discipline can sometimes be applied to answer questions in a different scientific area. Unmanned aerial vehicles, for example, were initially developed for war and surveillance purposes (Newcome, 2004). However, in the last 15 years they have had an exponential adoption in conservation science and precision agriculture (Fig. 1, Librán-Embid et al., 2020). Network theory, on the other hand, was initially developed in the context of social sciences in the 1930s (Borgatti et al., 2009), but was quickly adopted by ecologists years later to study food webs and it has greatly developed afterwards (Bascompte, 2007). 


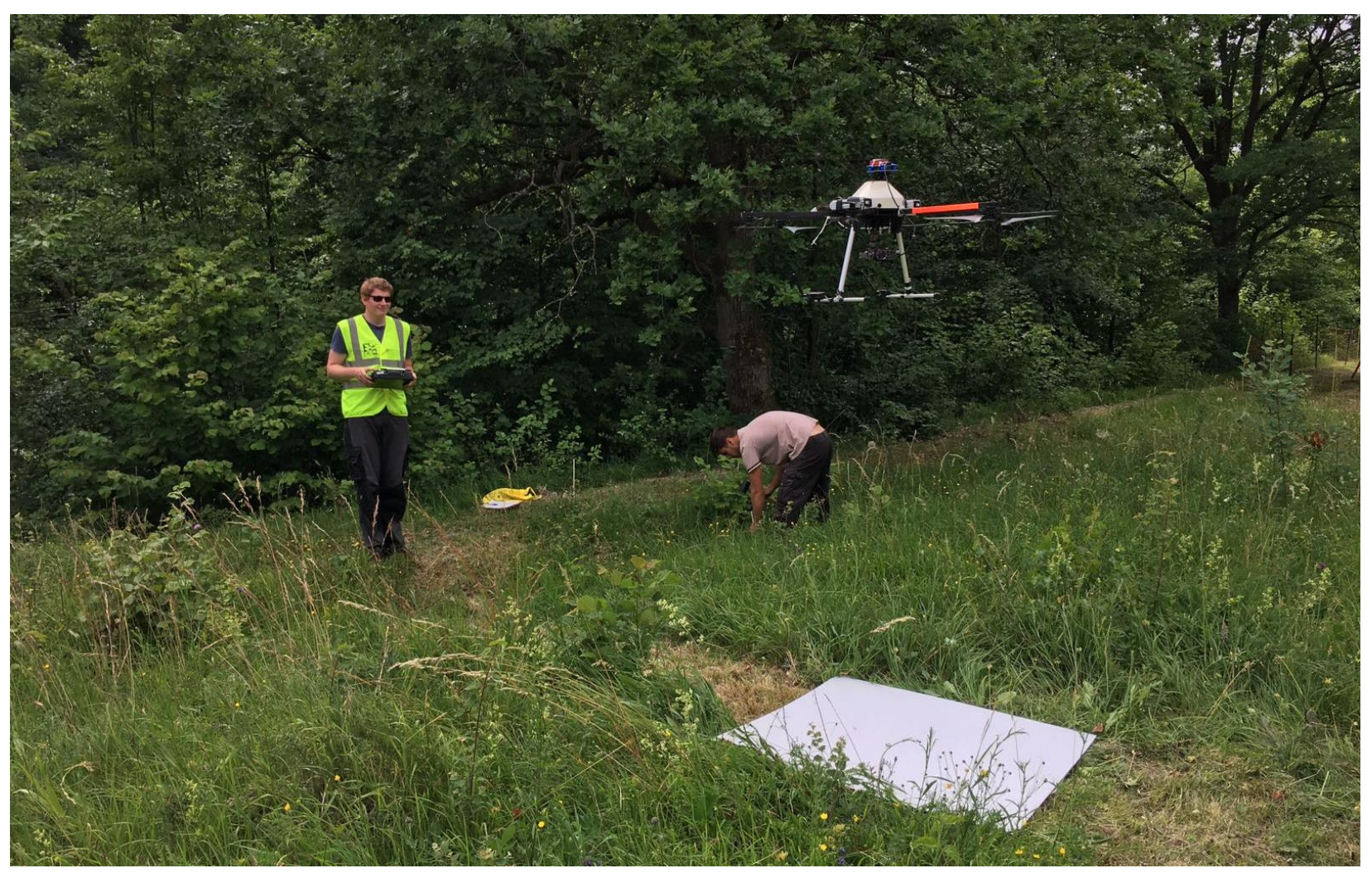

Figure 1. Unamnned aerial vehicle (octocopter) used for the assessment of the flower diversity of calcareous grasslands. () Maxim Bogdanowitsch.

The recent fast advance in technology and especially computer science has allowed to handle large amounts of ecological data (Allan et al., 2018). Furthermore, ecologists have benefited from the concomitant development of statistical methods, such as mixed models. These were developed theoretically around three decades ago (Wolfinger and O'connell, 1993), but were only implemented in open source software more recently (Bates et al., 2006; Juricek, 2003). As a consequence of both phenomena, the complexity of the hypotheses that can currently be tested in ecology through statistical modelling could not be even imagined 15 years ago.

It is fairly clear today that the battle of conservation science to protect biodiversity exclusively in huge nature reserves will be lost in the middle term because of human pressure and illegal activities (Allan et al., 2017; Pringle, 2017). These conservation efforts need to continue as far as possible to protect many vulnerable and rare species that cannot survive in disturbed areas and are reservoirs of genetic and functional diversity (Allison et al., 1998; Bruner et al., 2001). Agricultural expansion and intensification have contributed to ecosystems degradation, but 
agriculture is an unavoidable companion of humanity and it is the main source of food and other goods (Duncan and Duncan, 1996; Laurance et al., 2014).

Agriculture and biodiversity do not need to be mutually exclusive (Chappell and LaValle, 2011). In fact, an increasing number of studies are focusing on, not just reducing the impacts of agricultural activities on natural and semi-natural habitats, but rather designing multifunctional biodiversity-friendly agricultural landscapes (Grass et al., 2019; Tscharntke et al., 2005). In these, landscape composition and configuration are taken into account in order to support biodiversity and agricultural activities by increasing the provision of ecosystem services such as pollination and biological control of agricultural pests (Grass et al., 2019; Tscharntke et al., 2005). If we can design these landscapes, pressure on natural reserves will decrease and food production will increase, helping humankind and all other types of life on Earth.

Such an ambitious objective can only be reached by embracing the complexity of the interactions among species and their environment. The effects of habitat fragmentation on ecological networks, for example, cannot be understood by analyzing single species or single interactions, simply because of the existence of emergent properties associated to increasing levels of complexity (Ponge, 2005). Because of the existence of emergent properties, biological systems tend to be more complex than physic systems. The performance of a car, for example, can be predicted by understanding the properties of its single components (i.e. its wheels, windows, etc) but the behavior of ecological networks cannot be predicted by understanding how single species act in isolation from the others.

In this context, the concept of ecological metaneworks (Fig. 2) gains special importance as it permits to link interactions between species with the habitat fragments where they occur (Emer et al., 2018; Hagen et al., 2012). This strategy is especially useful in agricultural landscapes, which are usually composed by complex mosaics of crops and fragments of natural or semi-natural habitats (Bennett et al., 2006). By using metanetworks, species interactions and habitat fragments can be studied as an integral dynamic unit and biodiversity conservation in multifunctional agricultural landscapes can be better achieved. 


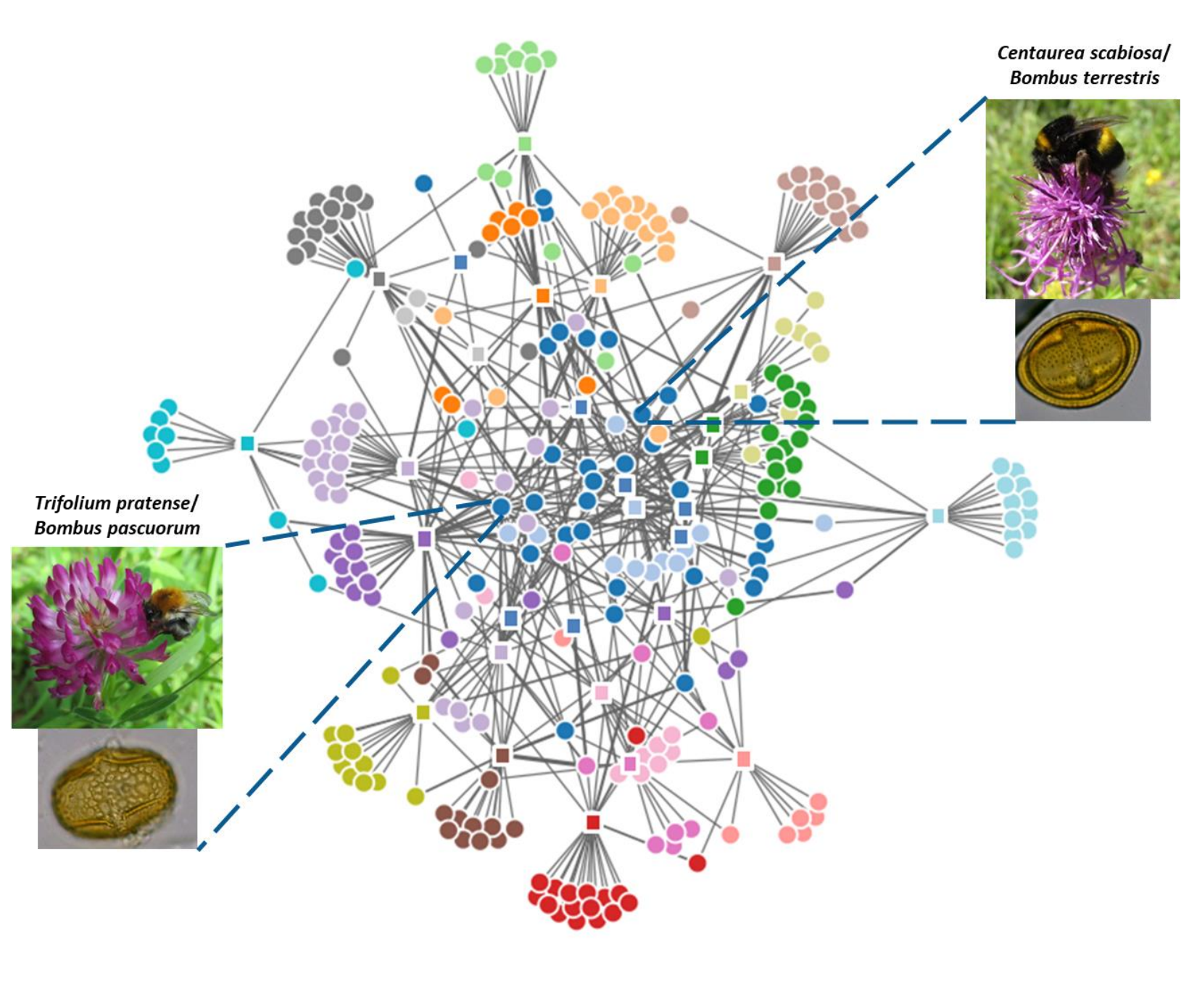

Figure 2. Pollen transport metanetwork structure among calcareous grassland fragments and unique pairwise plant-flower visitor interactions ( $n=29$ and $n=263$, respectively). Circles indicate pairwise plant- flower visitor interactions and squares represent sites. Interactions occurring in at least two sites form links between sites. Thickness of links (gray lines) is proportional to interaction abundance. Colors represent metanetwork modules based on the Walktrap community-finding algorithm (igraph package). This algorithm indicates the presence of sub-graphs that constitute a distinctive community. Nodes with greater centrality occur in the central positions of the graph based on the gravitational force on degree (Bannister et al., 2013). 


\section{Study region}

My study region comprises 285 sharply delimited semi-natural calcareous grasslands around the city of Göttingen (Germany) that differ in size, spatial connectivity, management and successional stage (Krauss et al., 2003b). These grasslands are embedded in an agricultural matrix mainly composed of arable land (42\%) and managed European beech (Fagus sylvatica) forests (37\%) (Krauss et al., 2003a). I conducted my study on 29 calcareous grassland fragments during the spring and summer of 2017 and 2018 (April-September). These fragments were selected in a previous study (Krauss et al. 2003a) along independent (i.e. non-correlated) gradients of habitat area and spatial connectivity. 


\section{$\mathrm{a}$}
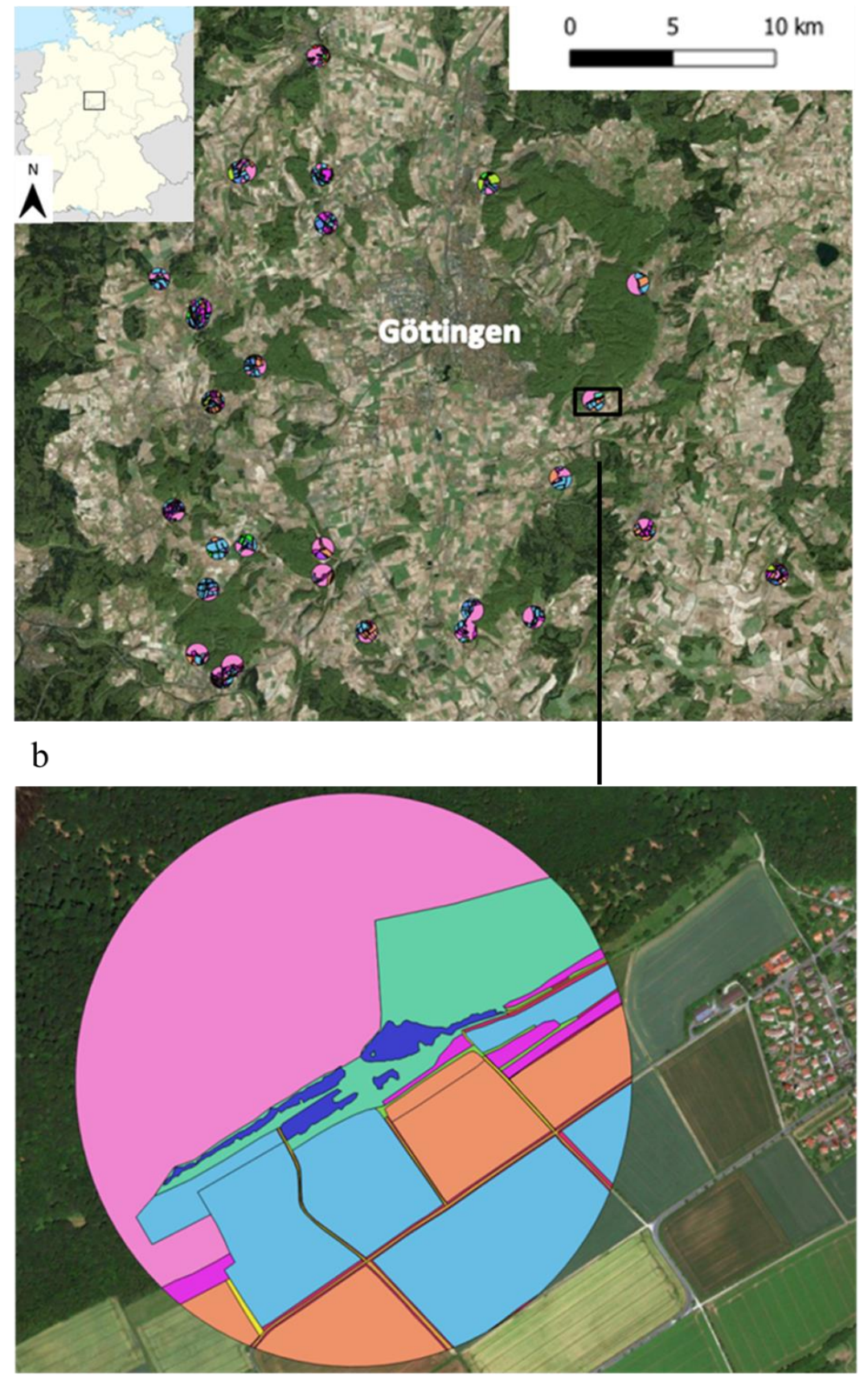

\begin{tabular}{|c|c|c|c|}
\hline Oilseed rape & Open forest & Water bodies & Pasture \\
\hline Grainfield & Closed forest & Streets & Calcareous grassland \\
\hline Maize & Field margin & Grassroad & Orchard \\
\hline Other crops & Hedgerow & Bare soil & Settelments \\
\hline
\end{tabular}

Figure 3. Study region in the surroundings of the city of Göttingen, Germany. a) The 29 studied calcareous grassland fragments with $500 \mathrm{~m}$ buffer of mapped cover types. b) Magnification of one fragment showing the land cover mapping in more detail. 


\section{Study system}

I studied the interactions established by bees (Hymenoptera: Apiformes), butterflies (Lepidoptera: Papilionoidea) and burnet moths (Lepidoptera: Zygaenidae) with flowering herbaceous plants in calcareous grasslands (Fig. 4). These taxa are the most active and abundant diurnal flower visitors in calcareous grasslands and are considered fundamental for the reproductive success of native plants (Steffan-Dewenter and Tscharntke, 2002).

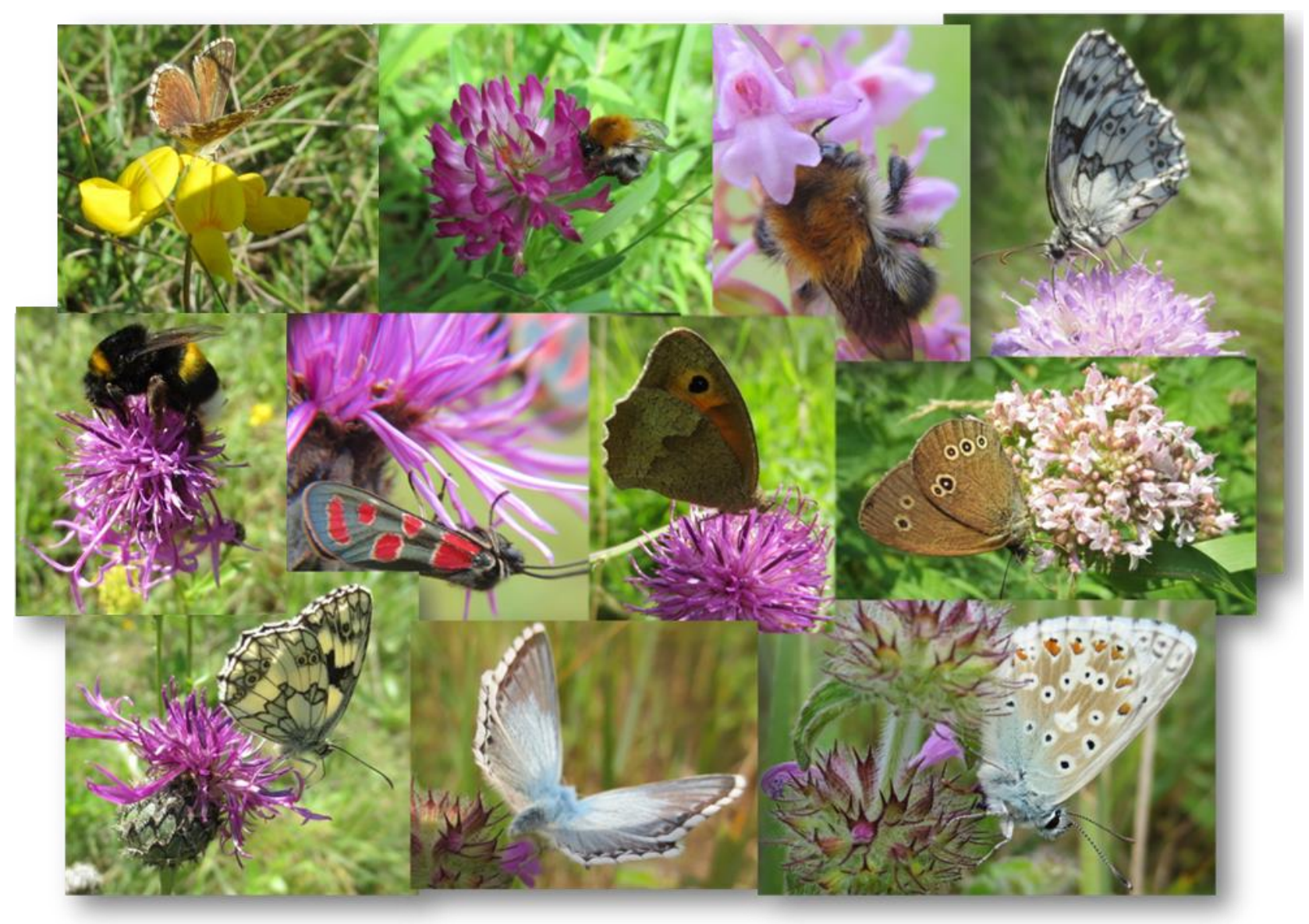

Figure 4. Examples of some common interactions in the studied calcareous grasslands. From top left to bottom right: Polyommatus coridon in Lotus corniculatus, Bombus pascuorum in Trifolium pratense, Bombus pascuorum in Gymnadenia conopsea, Melanargia galathea in Knautia arvensis, Bombus terrestris in Centaurea scabiosa, Zygaena carniolica in Centaurea scabiosa, Maniola jurtina in Centaurea scabiosa, Aphantopus hyperantus in Valeriana officinalis, Melanargia galathea in Centaurea scabiosa, Polyommatus coridon in Clinopodium vulgare (last two pictures) (C) Guillermo Gallardo Quilacán and Cristina Ganuza. 


\section{Objectives}

In this thesis my objectives are twofold:

1) My first objective was to thoroughly review unmanned aerial vehicles (UAVs) applications in terrestrial ecology and agriculture, to identify research gaps and to highlight potential new UAV applications in ecology coming from developments in agricultural research and viceversa. These objectives were conceived under the overarching objective of contributing to the development of biodiversity-friendly agricultural landscapes, which we consider a major worldwide objective in the years to come. Objective one was met in chapter one of this thesis and was recently published in Science of the Total Environment under the title 'Unmanned aerial vehicles for biodiversityfriendly agricultural landscapes - A systematic review' (doi: 10.1016/j.scitotenv.2020.139204)

2) My second objective was to study the charachteristics of plant-pollinator interaction networks across a habitat fragmentation gradient. The importance of pollination systems, their structure and resilience under land use and climate change is a fundamental challenge given the importance of pollination for agricultural production and for the integrity of all natural and seminatural habitats and the ecosystem services they provide. We used a novel approach to network theory, the concept of metanetwork, which allowed us to identify the most central plants, pollinators, interactions and habitat fragments to the system. This innovative approach can significantly help to adjust conservation efforts and strategies to the most important components of ecological networks and therefore to increase efficiency and accelerate results of conservation science. I met objective number two in chapters 2 and 3 of this thesis. 


\section{References}

Allan BM, Nimmo DG, Ierodiaconou D, VanDerWal J, Koh LP, Ritchie EG. Futurecasting ecological research: the rise of technoecology. Ecosphere 2018;9(5).

Allan JR, Venter O, Maxwell S, Bertzky B, Jones K, Shi Y et al. Recent increases in human pressure and forest loss threaten many Natural World Heritage Sites. Biological Conservation 2017;206:47-55.

Allison GW, Lubchenco J, Carr MH. Marine reserves are necessary but not sufficient for marine conservation. Ecological applications a publication of the Ecological Society of America 1998;8(sp1):S79-S92.

Bascompte J. Networks in ecology. Basic and Applied Ecology 2007;8(6):485-90.

Bates D, Sarkar D, Bates MD, Matrix L. The lme4 package. URL http://cran. r-project. org/740src/contrib/Descriptions/lme4. html 2006.

Bennett AF, Radford JQ, Haslem A. Properties of land mosaics: Implications for nature conservation in agricultural environments. Biological Conservation 2006;133(2):250-64.

Borgatti SP, Mehra A, Brass DJ, Labianca G. Network analysis in the social sciences. Science (New York, N.Y.) 2009;323(5916):892-5.

Breyer C, Heinonen S, Ruotsalainen J. New consciousness: A societal and energetic vision for rebalancing humankind within the limits of planet Earth. Technological Forecasting and Social Change 2017;114:7-15.

Bruner AG, Gullison RE, Rice RE, da Fonseca GA. Effectiveness of parks in protecting tropical biodiversity. SCIENCE 2001;291(5501):125-8.

Chappell MJ, LaValle LA. Food security and biodiversity: can we have both? An agroecological analysis. Agric Hum Values 2011;28(1):3-26.

Dakos V, Matthews B, Hendry AP, Levine J, Loeuille N, Norberg J et al. Ecosystem tipping points in an evolving world. Nature Ecology \& Evolution 2019;3(3):355-62.

Duncan CAM, Duncan CA. The Centrality of Agriculture: Between Humankind and the Rest of Nature: McGill-Queen's Press-MQUP; 1996.

Egli L, Meyer C, Scherber C, Kreft H, Tscharntke T. Winners and losers of national and global efforts to reconcile agricultural intensification and biodiversity conservation. Global change biology 2018;24(5):2212-28. 
Emer C, Galetti M, Pizo MA, Guimarães PR, Moraes S, Piratelli A et al. Seed-dispersal interactions in fragmented landscapes - a metanetwork approach. Ecology letters 2018;21(4):484-93.

Ge M, Lebling K, Levin K, Friedrich J. Tracking progress of the 2020 climate turning point. World Resources Institute,(technical report) 2019.

Grass et al. Land-sharing/-sparing connectivity landscapes for biodiversity services and conservation 2019.

Hagen M, Kissling WD, Rasmussen C, Am Aguiar M de, Brown LE, Carstensen DW et al. Biodiversity, species interactions and ecological networks in a fragmented world. In: Advances in ecological research: Elsevier; 2012. p. 89-210.

Krauss, J., Steffan-Dewenter, I. and Tscharntke, T. 2003a. Local species immigration, extinction, and turnover of butterflies in relation to habitat area and habitat isolation. Community ecol., 137: 591-602.

Krauss, J., Steffan-Dewenter, I. and Tscharntke, T. 2003b. How does landscape context contribute to effects of habitat fragmentation on diversity and population density of butterflies? J. Biogeogr., 30: 889-900.

Laurance WF, Sayer J, Cassman KG. Agricultural expansion and its impacts on tropical nature. Trends in ecology \& evolution 2014;29(2):107-16.

Librán-Embid F, Klaus F, Tscharntke T, Grass I. Unmanned aerial vehicles for biodiversityfriendly agricultural landscapes - A systematic review. Science of the Total Environment 2020;732:139204.

Newcome LR. Unmanned Aviation: A Brief History of Unmanned Aerial Vehicles. Reston, VA: American Institute of Aeronautics and Astronautics; 2004.

Ponge J-F. Emergent properties from organisms to ecosystems: towards a realistic approach. Biological Reviews 2005;80(3):403-11.

Pringle RM. Upgrading protected areas to conserve wild biodiversity. Nature 2017;546(7656):91-9.

Reid WV, Mooney HA. The Millennium Ecosystem Assessment: testing the limits of interdisciplinary and multi-scale science. Current Opinion in Environmental Sustainability 2016;19:40-6.

Rockström J, Steffen W, Noone K, Persson A, Chapin FS, Lambin EF et al. A safe operating space for humanity. Nature 2009;461(7263):472-5.

Steffan-Dewenter I, Tscharntke T. Insect communities and biotic interactions on fragmented 
calcareous grasslands - a mini review. Biological Conservation 2002;104(3):275-84.

Tscharntke T, Klein AM, Kruess A, Steffan-Dewenter I, Thies C. Landscape perspectives on agricultural intensification and biodiversity - ecosystem service management. Ecology letters 2005;8(8):857-74.

Wolfinger R, O'connell M. Generalized linear mixed models a pseudo-likelihood approach. Journal of statistical Computation and Simulation 1993;48(3-4):233-43. 


\section{Chapter 1}

\section{Unmanned aerial vehicles for biodiversity-friendly agricultural landscapes - A systematic review}

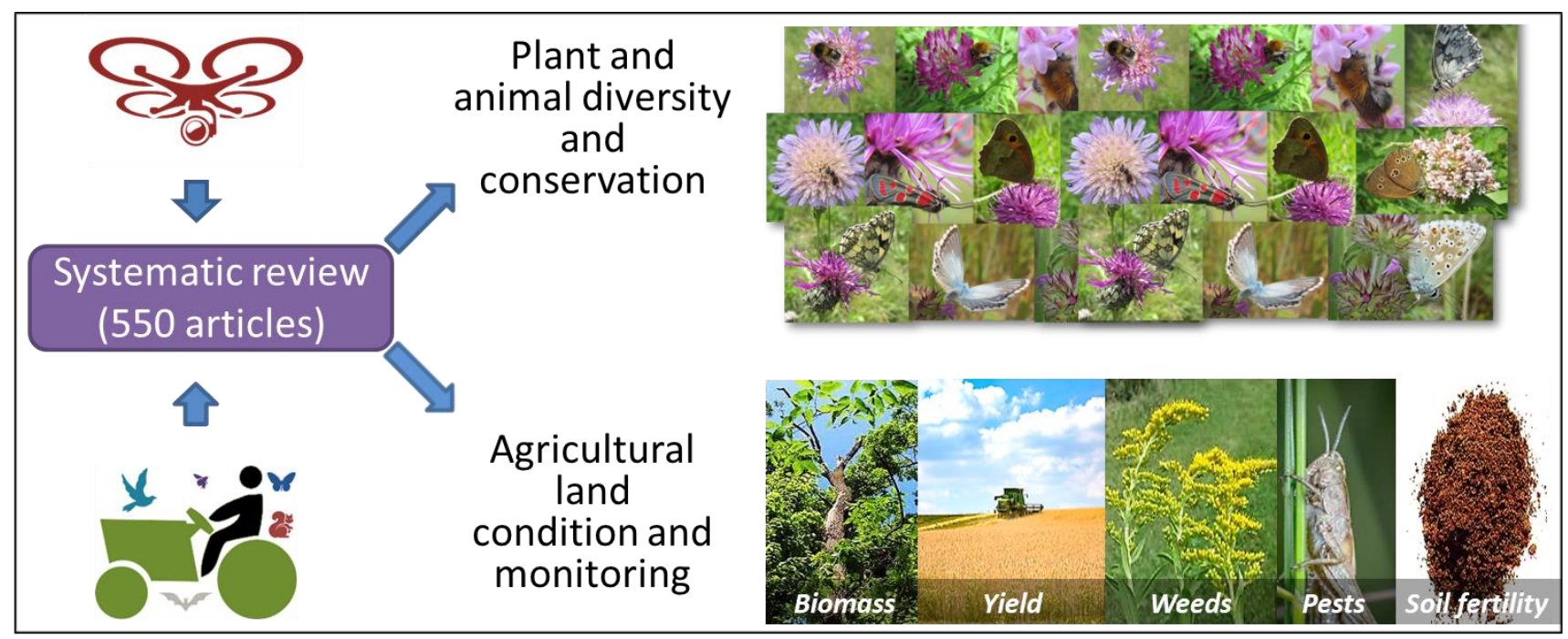

Felipe Librán-Embid, Felix Klaus, Teja Tscharntke, Ingo Grass

Published in Science of the Total Environment 2020: 732, 139204

doi: 10.1016/j.scitotenv.2020.139204 


\begin{abstract}
The development of biodiversity-friendly agricultural landscapes is of major importance to meet the sustainable development challenges of our time. The emergence of unmanned aerial vehicles (UAVs), i.e. drones, has opened a new set of research and management opportunities to achieve this goal. On the one hand, this review summarizes UAV applications in agricultural landscapes, focusing on biodiversity conservation and agricultural land monitoring, based on a systematic review of the literature that resulted in 550 studies. Additionally, the review proposes how to integrate UAV research in these fields and point to new potential applications that may contribute to biodiversity-friendly agricultural landscapes. UAV's imagery can be used to identify and monitor plants, floral resources and animals, facilitating the detection of quality habitats with high prediction power. Through vegetation indices derived from their sensors, UAVs can estimate biomass, monitor crop plant health and stress, detect pest or pathogen infestations, monitor soil fertility and target patches of high weed or invasive plant pressure, allowing precise management practices and reduced agrochemical input. Thereby, UAVs are helping to design biodiversity-friendly agricultural landscapes and to mitigate yield-biodiversity trade-offs. In conclusion, UAV applications have become a major means of biodiversity conservation and biodiversity-friendly management in agriculture, while latest developments, such as the miniaturization and decreasing costs of hyperspectral sensors, promise many new applications for the future.
\end{abstract}

Key Words: Unmanned aerial systems (UAS), UAV, Drones, Smart farming, Yield-biodiversity trade-offs, Vegetation monitoring, Precision agriculture. 


\section{Introduction}

Agricultural land covers $34 \%$ of the world land area and approximately half of the habitable land on Earth (WWF, 2016). To meet growing food demands, agricultural production systems are increasingly including novel techniques that rely on remote sensing and intelligent machines. Unmanned aerial vehicles (UAV), agribots and their sensors allow small-scale treatment of crop plants and farm animals with high accuracy (Walter et al., 2017; Zhang and Kovacs, 2012). Together with GPS guidance, this technology can increase yield (Saavoss et al., 2016; Zhao et al., 2013), reduce agrochemical inputs (Bongiovanni and Lowenberg-Deboer, 2004), fuel and time spent on crop management (Bora et al., 2012). Its application promises more sustainable agriculture to meet present and future demands for food and other agricultural products without compromising sustainability (Bongiovanni and Lowenberg-Deboer, 2004; Tilman et al., 2002).

In addition to food provision, agricultural landscapes are also key for biodiversity conservation, given that natural habitats are increasingly scarce (Rockström et al., 2009; Steffen et al., 2015). In fact, agricultural landscapes in tropical and temperate regions are often composed by a complex mosaic of different land covers, including cropland (usually dominant) and fragments of natural and semi-natural habitats. These different land cover types interact with each other (e.g. by species spillover) and management strategies should, therefore, consider them as dynamic interacting units (Grass et al., 2019). In agroecosystems, biodiversity at the local (i.e. field) scale is driven by colonization from the surroundings and, therefore, relies on source (natural and seminatural) habitats in the proximities of cropland (Tscharntke et al., 2005). Protection of species that provide ecosystem services, such as pollination and biological pest control (Tscharntke et al., 2007), is crucial for sustained high yield, particularly given the high dependency of crops on animal pollination (Garibaldi et al., 2013; Klein et al., 2007; Kremen et al., 2007; Ollerton et al., 2011) and the magnitude of crop losses to pests (Deutsch et al., 2018; Oerke, 2006; Savary et al., 2019). Cropland management has also an important influence on the ability of species to use and cross agricultural land, and consequently, on their population dynamics and survival in agricultural landscapes (Batáry et al., 2015; Boesing et al., 2018; Magioli et al., 2016; Tomé et al., 2015). However, biodiversity and ecosystem services conservation have usually been seen as an obstacle to high yield achievement in the short term (Paul et al., 2020). Cutting-edge technology brings new possibilities to overcome this challenge and may contribute to high yield and biological conservation alike. 
Unmanned aerial vehicles (UAVs) have experienced an exponential growth in the last 10 years, in terms of number of scientific publications (Fig. S1) and also regarding diversification of types and applications (Pajares, 2015). Fast technological advances and decreasing costs have made UAVs central for precision agriculture and smart farming, but also for a wide spectrum of research fields. This is partly due to their flexibility to transport many different kinds of sensors, their cost-effectiveness and their suitability to work at different scales (up to 1500ha) and in remote areas (Gago et al., 2015; Rango et al., 2006; Watts et al., 2010). In fact, UAV-based imagery outperforms other imaging acquisition technologies, such as satellites and manned aerial systems, in terms of increased temporal and spatial resolution, higher flexibility and reduced costs, especially when used for small ( $<5 \mathrm{ha}$ ) to medium (5-50ha) spatial scale objectives (Cruzan et al., 2016; Matese et al., 2015; Pádua et al., 2017; Wich and Koh, 2018). Therefore, UAVs are starting to be implemented by NGOs, state organizations, researchers and practitioners around the world.

Although UAVs capabilities are well known in ecology, precision agriculture and conservation science, this review focuses on the, so far little developed, contributions of UAVs to biodiversityfriendly agricultural landscapes. Classical definitions of the agroecosystem are usually restricted to the field scale (Wezel et al., 2009). However, considering the already mentioned importance of surrounding habitats for biodiversity and associated ecosystem services, and the capability of UAVs to work beyond the limits of the strict agricultural land, we consider that the concept should be broadened. We understand by biodiversity-friendly agricultural landscapes those that integrate local (e.g. cropland diversification, flower strips, hedgerows, set asides and reduced agrochemical input) and landscape (e.g. natural habitat protection, heterogeneous landscape structure) measures to benefit biodiversity (Landis et al., 2000; Tscharntke et al., 2012). The interdependence between land use types in the agricultural landscape determines that sustainable development goals (e.g. zero hunger) will only be achieved by concealing food production and biodiversity conservation under the same joint effort (Kremen and Merenlender, 2018; RosaSchleich et al., 2019). Therefore, the objectives of this systematic review are 1) to summarize current applications of UAVs in ecology, precision agriculture and conservation science and 2) to identify potential applications towards the development of biodiversity-friendly agriculture at local and landscape scales. 


\section{Methods}

A bibliographic search was conducted in Scopus and Web of Science on October 1st, 2019. Our search terms comprised the words unmanned, RPAS (Remotely Piloted Aircraft Systems) and either conservation, ecology, biodiversity, richness or agriculture. The word unmanned was used to capture studies on unmanned aerial vehicles (UAVs), unmanned aerial systems (UASs), unmanned aircraft systems (UASs) and unmanned aircraft vehicles (UAVs). We did not use the term drone, which usually occurs in addition to the most frequent term unmanned, to avoid retrieving articles regarding the ecology of male honeybees. As we were only interested in terrestrial landscapes, studies including the words maritime, ocean and sea were excluded. The exact search words used and other details can be found in the supporting information. To be included in the review, studies were required to: 1) Refer to or use unmanned aerial vehicles and no other type of ground or aquatic systems. 2) Focus on UAVs applications and not on technical properties (e.g. no studies focusing on endurance, manoeuvrability, etc.).

1946 articles were obtained as a result of the Scopus (1143) and Web of Science (803) searches. After excluding duplicates and unsuitable studies 529 articles were kept. We further added 21 additional publications that were found to be suitable for our review but did not appear on the original search totalizing 550 articles.

\section{UAVs applications}

Land cover mapping and classification has experienced a breakthrough with the advent of UAVs. UAVs can get very high spatial $(<1 \mathrm{~cm} / \mathrm{px})$ and temporal resolution images at relatively low cost when compared to manned airborne or satellite systems (Dufour et al., 2013; Lim et al., 2018; Ruwaimana et al., 2018; Whitehead and Hugenholtz, 2014). Classification has gone from differentiation among conspicuous land cover classes such as bare ground on rangelands (Breckenridge et al., 2012) to high resolution 3D maps of forests (Baena et al., 2017; Dandois and Ellis, 2013), and finally, to detailed land-use classifications of habitat types and land-cover classes (Ahmed et al., 2017; Strong et al., 2017). Plant and soil monitoring have also significantly improved since UAV imaging appeared. Particularly, monitoring of natural and semi-natural habitats in the context of restoration efforts (Malenovský et al., 2017; Reif and Theel, 2017; Zahawi et al., 2015) and recovery monitoring after fire events (Silva et al., 2014). 
In the context of precision agriculture, cropland monitoring is rapidly evolving from traditional local assessments based on visual analysis to cutting-edge non-destructive methods based on optical remote sensing. Diagnostic information can be derived from the images and indices taken from on-board sensors; including biomass, disease, water stress and lodging; and is later used for crop management, yield forecasting, and environmental protection (Zhang and Kovacs, 2012). Constant and high resolution monitoring can precisely inform where and when applications are needed throughout the growing period of a crop, a former unfeasible task at farm scale given logistic and economic constrains. Farmers are therefore increasingly demanding flexible and high resolution systems (<20cm/px; Bareth et al., 2015) to monitor crops on fine scale. Manned aerial imagery lacks flexibility and cannot provide data of enough temporal resolution for this task at affordable costs for most farmers. On the side of satellites, even the best current commercial ones are not able to provide data of enough spatial resolution $(31 \mathrm{~cm} / \mathrm{px}$, WorldView4) for precise crop monitoring at the farm scale. Centimetre and sub-centimetre imagery resolution, as the one provided by UAVs, contributes to a more accurate assessment of structural and biochemical plant traits (Jay et al., 2019). Thus, UAVs are helping to maximize efficiency in the applications of fertilizers, herbicides and insecticides (Gebbers and Adamchuk, 2010), and concomitantly, to minimize their impacts on the environment. Therefore, UAVs represent one of the most suitable available systems for crop monitoring objectives at farm scale.

In the following, topics of interest focusing on current and possible future applications of UAVs for the development of biodiversity-friendly agricultural landscapes are discussed (Table 1). Within each section, areas of interest related to UAV research are identified and related implications, relevance and knowledge gaps are discussed in further detail under the section "Perspectives on future research". 
Table 1. Overview table of UAV applications, giving a description of the application and a few major references.

\begin{tabular}{|c|c|c|}
\hline UAV application & Description & Major references \\
\hline 3.1 Biodiversity conservation & $\begin{array}{l}\text { Identification and monitoring of } \\
\text { single plant species and plant } \\
\text { species richness estimation. }\end{array}$ & $\begin{array}{l}\text { (Getzin et al., 2012; Ahmed et al., } \\
\text { 2017; Malenovský et al., 2017; } \\
\text { Capolupo et al., 2015; Knoth et al., } \\
\text { 2013; Cruzan et al., 2016; Silva et } \\
\text { al., 2014; Michez et al., 2016) }\end{array}$ \\
\hline b. Animal diversity & $\begin{array}{l}\text { Identification and monitoring of } \\
\text { animal populations and } \\
\text { communities as well as habitat } \\
\text { quality, based on vegetation } \\
\text { properties. }\end{array}$ & $\begin{array}{l}\text { (Mulero-Pázmány et al., 2014; } \\
\text { Chrétien et al., 2016; Hodgson et al., } \\
\text { 2016; Weissensteiner et al., 2015; } \\
\text { Goebel et al., } 2015 \text { Habel et al., } \\
\text { 2016; Forbey et al., 2017) }\end{array}$ \\
\hline $\begin{array}{l}\text { 3.2 Agricultural land } \\
\text { monitoring } \\
\text { a. Plant height and biomass } \\
\text { b. Yield and nutrient status } \\
\text { c. Pest and pathogen damage }\end{array}$ & $\begin{array}{l}\text { Plant traits estimation for yield } \\
\text { and carbon stock calculation. } \\
\text { Early and precise physiological } \\
\text { stress detection caused by pests, } \\
\text { pathogens, nutrients or water } \\
\text { deficit. }\end{array}$ & $\begin{array}{l}\text { (Bareth et al., 2016; Geipel et al., } \\
\text { 2014; Kachamba et al., 2017; Rey- } \\
\text { Caramés et al., 2015; Zhou et al., } \\
\text { 2017; Sanches et al., 2018; Gong et } \\
\text { al., 2018; Zarco-Tejada et al., 2013; } \\
\text { Shields and Testa, 1999; Smith et } \\
\text { al., 2015; Faithpraise et al., 2015; } \\
\text { Yue et al., 2012; Cardil et al., 2017; } \\
\text { Moriya et al., 2017) }\end{array}$ \\
\hline d. Soil fertility & $\begin{array}{l}\text { Estimation of soil organic } \\
\text { carbon content, soil residue } \\
\text { cover, soil moisture and soil } \\
\text { erosion. }\end{array}$ & $\begin{array}{l}\text { (Aldana Jague et al., 2016; Kavoosi } \\
\text { et al., 2018; d'Oleire-Oltmanns et al., } \\
\text { 2012; Bazzoffi, 2015; Acevo-Herrera } \\
\text { et al., 2010; Sugiura et al., 2007) }\end{array}$ \\
\hline $\begin{array}{l}\text { e. Weeds and other non-crop } \\
\text { plants }\end{array}$ & $\begin{array}{l}\text { Weed detection, characteristics } \\
\text { and management. }\end{array}$ & $\begin{array}{l}\text { (Shields et al., 2006; Rasmussen et } \\
\text { al., 2013; Pelosi et al., 2015; Peña et } \\
\text { al., 2013; Peña et al., 2015; Pantazi } \\
\text { et al., 2017; Pérez-Ortiz et al., 2015) }\end{array}$ \\
\hline
\end{tabular}




\subsection{Biodiversity conservation}

Species identification and monitoring in agricultural landscapes, from natural and semi-natural habitats to cropland, is fundamental for biodiversity conservation (Fig 1). UAVs derived information on plant and animal occurrence, movement and health status is providing important information for appropriate management. Besides the intrinsic value of biodiversity, animals and plants are also important for production in agricultural landscapes given the number of ecosystem services they provide (Balvanera et al., 2006; García-Feced et al., 2015).
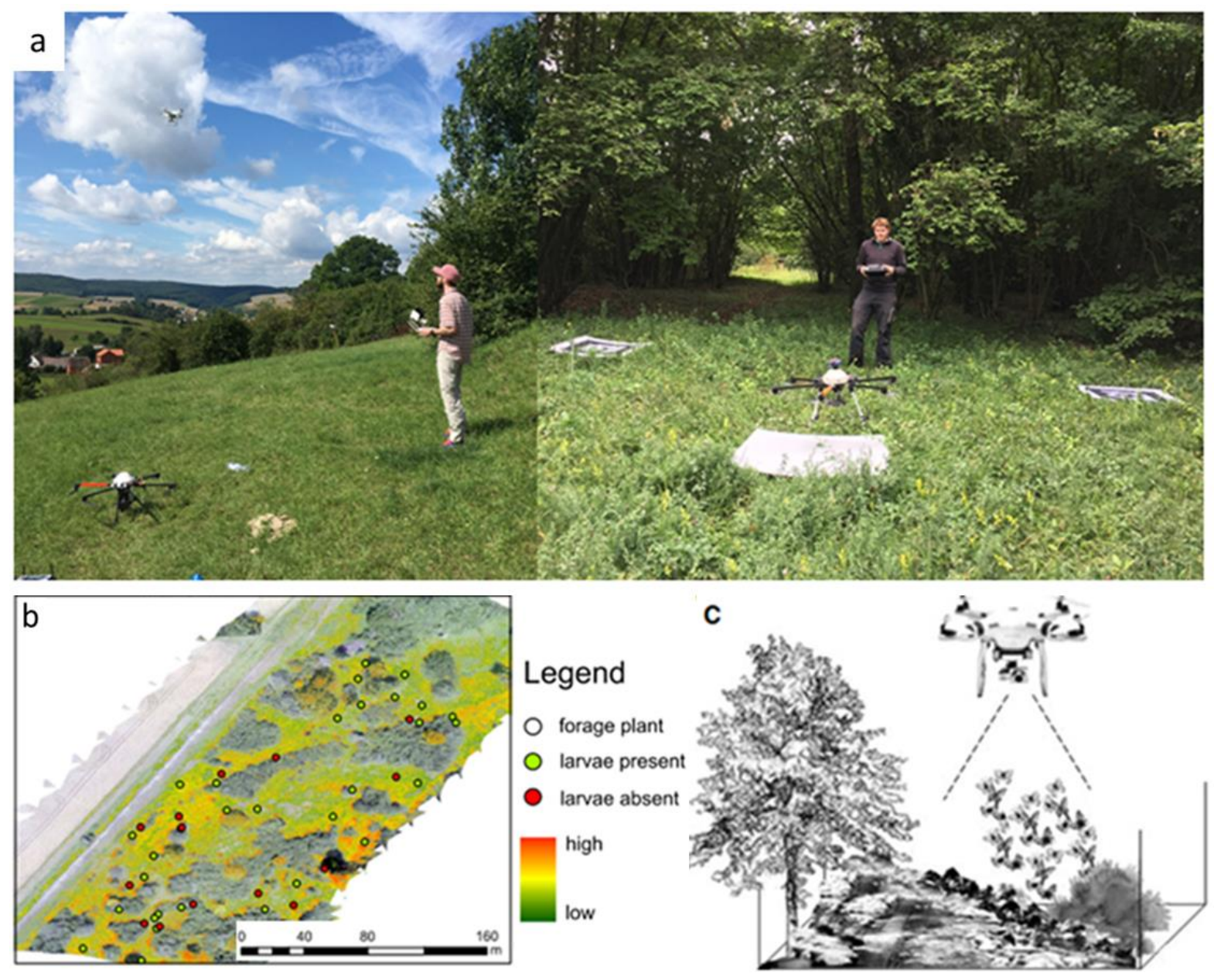

Fig. 1 a) Plant diversity assessment and floral resources mapping in grasslands of central Germany. Notice two different multirotor UAVs (one quadracopter and one hexacopter) performing image acquisition tasks in habitats of high plant diversity. b) UAV high-resolution imagery, based on a habitat suitability model of two lycaenid butterflies in Germany (modified from Habel et al., 2016, used with permission). Open circles represent presence of the butterfly's forage plants. Green circles depict presence of butterfly larvae and red circles absence of it. Warmer colors indicate areas of high habitat suitability. c) Butterfly tracking in South Korea (modified from Ivosevic et al., 2017, used with permission). 


\section{a. Plant diversity}

The expansion of monocultures and herbicide overuse has caused a dramatic decline in plant diversity in agricultural landscapes with negative consequences for ecosystem multi-functionality and production sustainability (Egan et al., 2014; Hooper et al., 2012). To alleviate this situation and increase landscape heterogeneity, measures including crop diversification, adjacent natural vegetation protection and agri-environmental schemes, have been promoted by state agencies in many countries (Batáry et al., 2015; Fahrig, 2017). Efficient plant diversity assessments in agricultural landscapes are fundamental for the success of these measures.

RGB (red-green-blue) cameras mounted on UAVs have enabled identification of not only conspicuous species in savannas (Cruzan et al., 2016), pastures (Silva et al., 2014) and riparian forest (Michez et al., 2016), but also biodiversity in deciduous forests (Getzin et al., 2012). Although comparatively cheap and simple, RGB cameras have been shown to achieve similar performances as LiDAR systems (Zahawi et al., 2015). Multispectral sensors (i.e. those able to capture 4-10 spectral bands) move a step forward, as they allow for more detailed vegetation classification and monitoring. In particular, those able to capture near-infrared spectra have been used in temperate systems to distinguish among land-cover classes and individual species with accuracies of $~ 90 \%$ (Ahmed et al., 2017; Knoth et al., 2013; Lu and He, 2017; Mora et al., 2015). They have also been successfully used to identify and monitor invasive plants (Samiappan et al., 2016b; Samiappan et al., 2016a) as in the case of Harrisia pomanensis in South Africa (Mafanya et al., 2017).

The general methodology implies the construction of orthomosaics from RGB or multispectral imagery (e.g. with AgiSoft software) followed by a segmentation process through object-based image analysis (OBIA). Later, spectral vegetation indices are derived from the imagery and tested for their capacity to identify the specific species or cover types (e.g. with random forests' algorithms). Finally, accuracy tests are performed (Michez et al., 2016). Knoth et al. (2013), for example, used this procedure to analyse a bog complex in Germany using color infrared images with a modified digital camera. Thanks to the small spatial resolution achieved in the study (1.5 $3 \mathrm{~cm} / \mathrm{px}$ ) they were able to discriminate a moss (Sphagnum spp), a herbaceous plant (Eriophorum vaginatum) and a deciduous tree (Betula pubescens) with high accuracy (Table S1). In a different study system, Ahmed et al. (2017), were able to precisely distinguish individual deciduous tree 
species, shrub communities and agricultural crops, by deriving orthomosaics and normalized difference vegetation index (NDVI) maps from true-color and multispectral imagery.

Although RGB and multispectral sensors may be sufficient for many objectives, hyperspectral sensors are usually regarded with the best potential for mapping purposes given the possibility to capture more than 200 bands in a broad spectral range $(\sim 350-2500 \mathrm{~nm})$ and high spectral resolution $(\sim 10 \mathrm{~nm})$ when mounted on manned or unmanned aerial vehicles (Colomina and Molina, 2014). The spectral diversity/variability hypothesis proposes that the number of plant species increases with the diversity of spectra observed (Heumann et al., 2015; Palmer et al., 2002; but see Schmidtlein and Fassnacht, 2017) and has been tested with hyperspectral sensors mounted on satellites or manned aerial systems (Mapfumo et al., 2016; Möckel et al., 2016; Wachendorf et al., 2018). This data has been used for biodiversity assessment in a wide range of ecosystems, including tropical forests (Cochrane, 2000), costal zones (Lange et al., 2004), wetlands (Gross and Heumann, 2014; Heumann et al., 2015) and grasslands (Lopatin et al., 2017; Möckel et al., 2016). However, in complex habitats, such as grasslands, accurate biodiversity assessment demands higher spatial resolution than manned aerial or satellite systems can reach (Capolupo et al., 2015; Lopatin et al., 2017), highlighting the relevance of UAVs as the only current remote solution available for biodiversity assessments in these habitats (Fig. 1a).

Until very recently, hyperspectral sensors were only available for manned aircraft and satellite systems (Mulla, 2013) given UAVs' payload limitations (Adão et al., 2017). Additionally, high costs associated to commercial hyperspectral sensors (ranging from USD 25,000 to USD 100,000; Association for Computing Machinery, 2017; CBRNE Tech Index, 2019) prohibited their wider public use. However, the increase in UAVs' payload capacity (up to $15 \mathrm{~kg}$ multirotor and up to 50kg fixed wing UAVs, Chen et al. 2016), in addition to the emergence of light and non-commercial low-cost hyperspectral sensors (USD700 USD2,000; Adão et al., 2017; Colomina and Molina, 2014; Nevala and Baden, 2018; Sigernes et al., 2018) in the last few years, are making it possible for a larger public to have access to UAV-on-board hyperspectral sensors. Cao et al. (2018), for example, used a 470g commercial hyperspectral camera (USD 50,000), with a spectral resolution of 4nm, to identify mangrove species in China. Sigernes et al. (2018), on the other hand, constructed a light (200g) low-cost (USD 700) hyperspectral sensor and successfully produced orthomosaics from NDVI image sequences taken from a UAV octocopter. 
In practice, the fact that commercial hyperspectral sensors adapted for UAVs are still approximately ten times more expensive than multispectral ones highlights the importance of carefully considering the most cost-efficient sensor for each specific objective. Multispectral or RGB imagery may offer cheaper and easier solutions than hyperspectral imagery in ecosystems where all types of sensors record similar accuracy levels for species classification, such as forests (Michez et al., 2016). Nonetheless, limitations need to be overcome in terms of automated image classification methods (e.g. by including elevation data, Cruzan et al., 2016). Furthermore, given the high spatial resolution needed for vegetation identification at the species level and the current resolution of most current commercial RGB and multispectral sensors, UAVs need usually to be flown at very low altitudes $(<20 \mathrm{~m})$. This makes it impractical to cover big areas given the amount of time needed for the flights and image mosaicking (Bertacchi et al., 2019). These problems might soon be overcome by the development of new sensors with increased resolution power.

\section{b. Animal diversity}

Data on the availability of vegetation used for food is fundamental to understand animals' occurrence (Forbey et al., 2017). The capacity of sensors mounted on UAV to deliver high resolution images, combined with high UAV spatio-temporal flexibility for mapping and characterizing microhabitats, provides new opportunities for animal species habitat preference detection (Habel et al., 2016). UAVs' sensors have been used to measure structural properties (e.g. height metrics and phytochemical features) in forest, grass and shrub ecosystems (Anderson and Gaston, 2013; Forbey et al., 2017) and consequently the identification of areas with high protection value is expected to become more precise and efficient (Habel et al., 2016).

Conservation strategies (e.g. agri-environmental schemes), especially those directed towards specific species, may improve by employing UAVs. For example, the monarch butterfly (Danaus plexippus) relies almost exclusively on milkweed (Asclepias syriaca) as a larval food-plant. A recent decline in milkweed populations, due to increased use of glyphosate in maize and soya plantations in the USA, is threatening the butterfly survival (Pleasants and Oberhauser, 2013). Mapping and protecting milkweed populations is hence critical to protect this flagship species ( $\mathrm{Lu}$ and He, 2017). In this context, the combination of UAVs' surveys precision, range, speed 
and cost-efficiency could help to overcome former strategies' limitations and therefore to avoid the species' extinction.

Wildlife detection and management have also benefited from UAVs (Fig. 1c). Wildlife detection within field and in the field surroundings is an important component for the concept of biodiversity-friendly agricultural landscapes for two main reasons. On the one hand, an increased detection rate would reduce the number of animals unintentionally killed in agricultural landscapes during fieldworks (e.g. harvest period). Thermal cameras mounted on UAVs can be used to detect endothermic animals, therefore avoiding animal mortality and also increasing farmers harvest efficiency, as has been shown for deer fawn (Cukor et al., 2019), lapwing (Israel and Reinhard, 2017 - 2017) and Montagu's Harrier (Mulero-Pázmány and Negro, 2011). On the other hand, detection of certain animal species in the agricultural landscape might contribute to a better planning of agricultural and conservation strategies and eventually lead to win-win scenarios. Given its high conservation value and its role in rodent biological control in cereal fields, the Montagu's Harrier protection constitutes one of these mutually benefiting scenarios between conservation science and agricultural production.

Wasps' nests identification would be likewise important in agricultural landscapes given their importance as pest predators of many crops and their eventual danger to humans when undetected (Medeiros et al., 2019; Prezoto et al., 2019; Southon et al., 2019). Given the higher temperature of social wasps' nests compared to the surrounding environment (i.e. 5-10 ${ }^{\circ} \mathrm{C}$, Klingner et al., 2005), thermal cameras could also be applied to identify them, although, to our knowledge, this possibility has not yet been explored. Furthermore, vertebrate pollinators, such as hummingbirds and bats, would also be fundamental to detect given their crucial role in plant reproductive success (Rader et al., 2016). Their absence reduces fruit and/or seed production by $63 \%$ on average (Ratto et al., 2018). Bats are known for their importance as biological control agents, seed dispersers and pollinators of several wild plants and crops (Kunz et al., 2011), such as the Agave spp. (Trejo-Salazar et al., 2016). Birds are also fundamental pest predators (Boesing et al., 2017), the endemic lemon-bellied-white-eye Zosterops chloris, for example, was found to be the main bird predator in cacao agroforestry landscapes in Indonesia (Maas et al., 2015) and is therefore a key element for efficient biological pest control. Quantitative and spatially explicit information on the presence of these important animal groups (e.g. gathered with thermal 
cameras on UAVs) would be a tipping point for the design of biodiversity-friendly agricultural landscapes and for smart farming.

Density data collection over large areas has significantly improved and spread thanks to the advent of UAVs, given the avoidance of traditional aerial survey biases, greater spatio-temporal resolutions, and to the reduced impact of noise on wildlife (Chrétien et al., 2016). Multispectral imagery, in particular, has been recognized as more efficient than traditional human visual detection for animal discrimination, especially in the case of bird and mammal surveys (Chrétien et al., 2016). UAV-derived counts of colony-nesting birds, for example, are an order of magnitude more precise than traditional ground counts (Hodgson et al. 2016). For small but fixed objects, such as birds' nests, UAVs can obtain very detailed data from images, such as nestlings' age and number of eggs (Weissensteiner et al., 2015). Moreover, the possibility of using multispectral imagery and, in particular, the combination of visual and infrared spectrum sensors, allows tracking animals more efficiently and even at night (Chrétien et al., 2016; Ward et al., 2016). This may be particularly relevant to track small, low contrasting and nocturnal animals (e.g. rodents) that may otherwise be difficult to follow (Gonzalez et al., 2016). Images can be used for abundance estimates (with both manual and automated methods) and also to track changes in animal size, body shape and nutritive condition (Goebel et al., 2015).

\subsection{Agricultural land monitoring}

Agricultural land monitoring refers to the set of activities related to crop health and grow from soil fertility to yield calculation (Fig. 2). Early and precise plant physiological stress detection caused by pests, pathogens, nutrients or water deficit is of major importance (Lichtenthaler, 1998; Maimaitiyiming et al., 2017), not just for crop development and yield, but also for conservation objectives in agricultural land (e.g. biodiversity protection). Detecting a crop pest outbreak early enough, for example, may allow low-cost and environmentally friendly treatment, e.g. with biological pest control agents (Barrera, 2008; Gerling et al., 2001). 


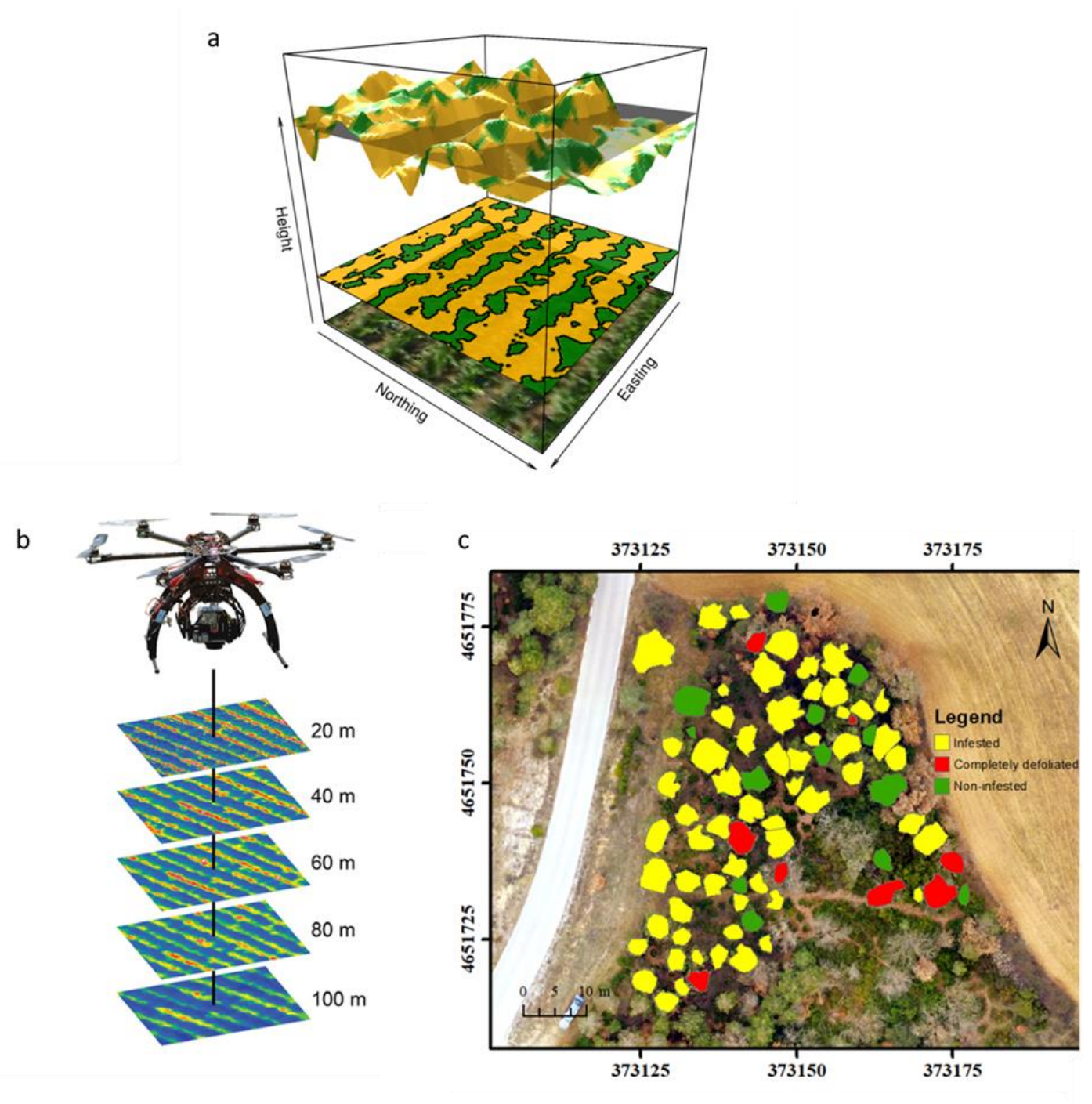

Fig. 2 UAV applications for vegetation monitoring in crops and forests. a) Plant height computation of a corn field (modified from Geipel et al., 2014). The lower part of the figure shows an RGB orthoimage and a classification layer based on the Excess Green Index (ExG) where green represents crop and yellow soil. The upper part shows the corresponding crop surface model height information as a 3D representation, colored by the ExG-classification. b) Surface temperatures at different heights from potato fields (modified from Faye et al. (2016), used with permission). Red stands for higher temperatures and blue for lower ones. c) Pine processionary moth defoliation assessment in Catalonia (modified from Cardil et al. (2017), used with permission). Yellow depicts infested trees, red completely defoliated trees and green non-infested trees. 


\section{a. Plant height and biomass}

In precision farming, management strategies often rely on estimations of biomass, crop growth, light use efficiency and carbon stocks to predict total yields and spatial yield variations, and to determine harvest dates (Bendig et al., 2014; Chen et al., 2012; Li et al., 2016). Plant growth is a good indicator of plant response to heat, drought or nutrient stress and therefore of crop performance. Bareth et al. (2016) used RGB imagery from a UAV and computer vision techniques to construct multi-temporal crop surface models of barley at three growth stages and found that plant height estimations derived from this method were as accurate as the more commonly used terrestrial laser scanning (Table S1). Furthermore, UAV multispectral imagery can also produce crop height estimates as accurate as those coming from LiDAR systems (Sofonia et al., 2019), at much lower costs.

Above-ground biomass is another important measure for agricultural and natural systems that can be applied to monitor ecosystem health, impacts of climate change and human activity (Liang et al., 2016). Above-ground biomass allows to estimate carbon sequestration, which is important for the global carbon cycle and for carbon emissions estimation and can be used for carbon conservation programs (Chen et al., 2012). In the past, the above-ground biomass of plants in an area was extrapolated by measuring the height (and width of trees in forests) of a sample of plants on the ground or by destructively sampling plants to directly measure their biomass (Gao et al., 2013). Today parameters such as canopy height, ground cover, and vegetation indices (e.g. NDVI) can be estimated using UAVs imagery and later used to model above-ground biomass (Bendig et al., 2014; Grüner et al., 2019). At small to medium scales, UAVs can produce consistent biomass estimates at significant smaller costs than manned aircraft (Kachamba et al., 2017).

Common procedures for plant height and biomass estimation involve the generation of 3D point clouds from RGB or multispectral imagery (e.g. with structure from motion techniques), followed by the construction of digital surface models (DSMs) and digital elevation models (DEMs) with software as Agisoft or Pix4D (Table S1). In grasslands, above-ground biomass estimations help to predict production (e.g. livestock forage), carbon storage, and wind erosion potential (Gao et al., 2013; Liang et al., 2016). Möckel et al. (2016), for example, used airborne hyperspectral data for fine-scale biodiversity predictions through pigment content and biomass analyses, based on the negative correlation between plant species diversity and above-ground biomass. Given the 
recent miniaturization and price reduction of UAVs, these habitats could be now studied at a much lower price. In fact, the use of UAVs enables us to non-destructively sample areas and to make small-scale estimations of above-ground biomass, which can be used for site-specific agricultural decision making in croplands and grasslands (Geipel et al., 2014; Liang et al., 2016).

Accurate tree height and biomass estimation is also possible through UAVs imagery based on color-infrared (Zarco-Tejada et al., 2014), multispectral (Shin et al., 2018) and hyperspectral sensors (Adão et al., 2017). This is especially important for orchards (e.g. olive and fruit trees), silvopastoral systems (Surový et al., 2018) and forestry (Tang and Shao et al., 2015). Forestry management, for example, might particularly benefit from these advances considering that tree height and biomass information are fundamental to determine productivity and harvesting time. Pine (Guerra-Hernández et al., 2017), eucalyptus (Wallace et al., 2016) and oak (Surový at al., 2018) plantations have already profited from UAV monitoring.

Although most studies report good accuracies for plant height and biomass estimation (Table S1), it is important to note that structure from motion approaches retrieve in general lower accuracies in heterogeneous crops, compared to homogeneous ones, such as monocultures. Increased spatial resolution and plant density information might contribute to higher accuracy in those scenarios (Grüner et al., 2019).

\section{b. Yield and nutrient status}

Yield prediction is naturally of principal interest for farmers, given its direct effect on income. However, it is also fundamental to adaptive crop management and balancing input applications (e.g. fertilizers). Avoidance of unnecessary inputs, as nitrogen and phosphorous, has positive effects on ecosystem functioning and biodiversity (Mozumder and Berrens, 2007). Therefore, yield and nutrient status predictions are central to the design of biodiversity-friendly agricultural landscapes. The Leaf Area Index (LAI), defined as the area of single sided leaves per area of soil, can link multispectral remote sensing to crop growth, yield and other biological measurements (López-Lozano and Casterad, 2013; Wu et al., 2007). Multispectral information can be used to calculate spectral indices related to LAI such as the NDVI (normalized ratio between the red and near infrared bands, Lelong et al., 2008). These spectral indices provide information about important vegetation properties, such as the chlorophyll concentration, water stress and plant productivity (Gago et al., 2015; Nemeskéri et al., 2019). LAI can be calculated at multiple 
phenological stages using RGB, TIR (thermal infra-red) and hyperspectral sensors and has been used in potato plantations (Roosjen et al., 2018), wheat (Yao et al., 2017), sorghum (Potgieter et al., 2017) and vineyards (Kalisperakis et al., 2015).

Imagery datasets from UAVs have allowed yield prediction in crops such as corn (Geipel et al., 2014), vineyards (Rey-Caramés et al., 2015), rice (Zhou et al., 2017), sugarcane (Sanches et al., 2018) and oilseed rape (Gong et al., 2018). The combination of spectral vegetation indices maps (e.g. Excess Green Index) with 3D surface models is a particularly important method for yield estimation (Geipel et al., 2014). However yield estimation accuracy based on imagery has not yet reached that of traditional methods in some crops (Geipel et al., 2014; Yin et al., 2011).

Nutrient status assessment through spectral indices has been studied in many crops (Liu et al., 2018; Schirrmann et al., 2016) and particularly well in vineyards. In the latter, leaf carotenoid content estimation, vigour and development have been estimated using high resolution hyperspectral (Zarco-Tejada et al., 2013) and multispectral imagery (Rey-Caramés et al., 2015), acquired from UAVs. It has been demonstrated that, given its higher spatial resolution, UAV imagery outperforms satellite decametric imagery in vineyard vigour assessment (Khaliq et al., 2019). Moreover, LAI estimation with hyperspectral data or 3D canopy models was found to be more accurate than estimations based on RGB 2D data (Kalisperakis et al., 2015).

Current methods for yield and nutrient status estimation show already satisfactory results (Table $\mathrm{S} 1)$. Research is now focused on increasing efficiency in terms of costs/time reduction and increased accuracy. Cost reduction is mostly associated to technology development and will continue in the years to come as UAVs and sensors tend to get more economic. Reduced time involves finding the optimal spatial resolution for each objective, where important vegetation details can be captured without increasing data noise. Avoiding unnecessary high resolution also reduces image processing and aerial campaigns time, as UAVs might be flown at higher altitudes, covering more area per flight.

\section{c. Pest and pathogen damage}

Some pests and pathogens have potential to gain uncontrolled outbreak character causing dramatic losses to agriculture (Singh and Satyanarayana, 2009). Attempts to reduce these losses cost farmers a considerable amount of time, money and effort (Deutsch et al., 2018; Oliveira et al., 2014). Chemical pest control, the most used pest control method, is also an important driver 
of biodiversity loss, negatively affecting surrounding areas and beneficial insects such as pollinators (Gill et al., 2012; Jong et al., 2008; Woodcock et al., 2017). Furthermore, pesticides costs might take a substantial part of farmers' budget, making the production chain more expensive and compromising the sustainability of small and medium farmers' livelihoods (Bourguet and Guillemaud, 2016). Therefore, early and precise detection of incipient pests and pathogens means a breakthrough for agriculture and conservation, as these could be treated fast and locally, well before reaching economic thresholds. Consequently, this early detection could favour farmers' budget, biological conservation and ecosystem health and functioning.

Although in its infancy, crop pest and pathogen damage can be monitored with UAV-based imagery given the specificity of the structural and chemical changes occurring in attacked plants (Maes and Steppe, 2019; Mahlein, 2016). One of the main advantages of UAV imagery is the possibility to detect pest and pathogen attack before visual signs emerge. Thermal and fluorescence imaging can provide such early identification of attacked plants based on the modification of plant cuticular and stomatal conductance (Oerke et al., 2006) and chlorophyll fluorescence (Mahlein, 2016), respectively. However, both methods lack the capacity to distinguish among diseases.

UAV-based multispectral sensors can assist in early and specific pest and pathogen detection through spectral vegetation indices (Garcia-Ruiz et al., 2013). Although, UAV-based multispectral imagery was found to reach higher accuracy than aircraft imagery for this purpose; moderate overall accuracy levels and a high proportion of false negatives demand further improvements on these technics (Garcia-Ruiz et al., 2013). One possible improvement might be to combine multispectral and thermal imagery, which has retrieved encouraging results in legal opium poppy plantations (Calderón et al., 2014). The simpler RGB sensors might not be as appropriate for early detection objectives but, nonetheless, they can provide accurate maps of location and severity of affected plants (Cardil et al., 2017; Sugiura et al., 2016; Tetila et al., 2017). Considering the lower costs of RGB sensors compared to multispectral ones, it is important to adapt methods to research objectives in order to achieve cost-effective solutions (del-Campo-Sanchez et al., 2019).

Despite the above, hyperspectral imaging has the biggest potential for species specific, precise and early pest and pathogen detection (Mahlein et al., 2018), in particular when combined with 
thermal data (López-López et al., 2016). Vanegas et al. (2018), for example, developed a methodology to detect grape phylloxera (Daktulosphaira vitifoliae) attack in vineyards by combining digital surface models obtained from RGB imagery with spectral vegetation indices coming from multispectral and hyperspectral data (Table S1). Vanegas et al. (2018) used a methodology that produced promising results and could be adapted to other systems provided that information on the optical properties of healthy and attacked plants is available. Spectral signatures between healthy and unhealthy plants are usually not different across all spectral regions; therefore, it is important that the used sensors capture radiation at the correct wavelengths for the given study system (Moriya et al., 2017; Vanegas et al., 2018). Given the high amount of data generated with hyperspectral sensors (Mahlein, 2016), it is recommendable to carefully select just the informative spectral regions and the correct spatial resolution needed in order to optimize data analysis.

Non-imagery UAVs have also been applied in different studies to reduce pest and pathogen damage to crops. Smith et al. (2015), for example, studied the long distance dispersal potential of an insect pest (Thrips tabaci) transmitting a pathogenic virus in onion crops. They used UAVs equipped with sticky card traps to determine seasonal dynamics of insect occurrence in the planetary boundary layer and virus infection rates to better understand pest dynamics of T. tabaci. Likewise, UAVs have been used to deploy wasp and fly parasites of the African armyworm (Spodoptera exempta) in cereal crops, improving the quality of the crop and replacing pesticides (Faithpraise et al., 2015).

\section{d. Soil fertility}

RGB and multispectral imagery have also been used to estimate soil residue cover (Kavoosi et al., 2018), soil erosion (Bazzoffi, 2015; d'Oleire-Oltmanns et al., 2012), soil moisture (AcevoHerrera et al., 2010; Sugiura et al., 2007) and soil organic carbon content in bare cultivated soils (Aldana-Jague et al., 2016b). Soil residue cover, for example, is fundamental to sustainable agriculture as appropriate residue cover improves soil and water quality and reduces soil erosion (Kavoosi et al., 2018). Kavoosi et al. (2018) used a combination of multispectral satellite imagery (Landsat $8 \mathrm{OLI}$ ) and RGB imagery from a UAV and found that multispectral imagery predicts soil residue cover with higher precision than RGB imagery. 
Soil erosion is a serious problem in Europe (Bazzoffi, 2015) and especially in semi-arid regions (d'Oleire-Oltmanns et al., 2012), as it causes soil loss and degradation and is considered an indicator of desertification (López-Bermúdez, 1990). Soil erosion is accelerated by inappropriate human activities and is a useful indicator to monitor land degradation (Wang et al., 2016). Wang et al. (2016) and d'Oleire-Oltmanns et al. (2012) used commercial digital cameras (i.e. RGB imagery) mounted on UAVs to produce DEMs and sub-decimetre orthomosaic images through which they were able to precisely map, quantify and monitor gully erosion (Table S1). High resolution multispectral imagery has also proved useful in the prevention and management of soil erosion through the interactions between sediment connectivity and vegetation (Estrany et al., 2019).

Soil moisture estimates are essential for precision agriculture, coastal monitoring, fire risk estimation and flood prevention (Kumar et al., 2018; Wang et al., 2018). They have been calculated with high accuracy in agricultural fields using L-band radiometers (Acevo-Herrera et al., 2010), thermal cameras (Sugiura et al., 2007; Wang et al., 2018), multispectral sensors (Wang et al., 2018) and UAV hyperspectral imagery (Ge et al., 2019b). Finally, estimates of soil organic carbon are extremely important as this property is related to water holding capacity and nutrient availability of soils. It is also linked to climate regulation, as atmospheric $\mathrm{CO}_{2}$ concentrations depend on terrestrial carbon, whose largest reservoirs are soils (Aldana Jague et al., 2016a). Although the most informative spectral bands related to soil organic carbon estimation occur in both, the visible near-infrared (350-1000nm) and the shortwave near-infrared (1000-2500nm) regions (Laamrani et al., 2019); Crucil et al. (2019) found that model predictions of soil organic carbon based only on the visible near-infrared spectral range perform as well as those based on both regions. Furthermore, they found that models based on multispectral narrow bands performed better than those of hyperspectral sensors. Crucil et al. (2019) key findings mean that expensive and heavy hyperspectral sensors (e.g. spectro-radiometers) are not needed for soil organic carbon estimation. Instead, lighter UAV adaptable hyperspectral sensors (i.e. typically those covering a spectral range of 400-1100 nm), and particularly multispectral sensors, might perform even better. The study of Aldana-Jague et al. (2016b), for example, used UAV multi-spectral imagery for soil organic carbon estimation in barley fields and obtained highly accurate models (average $\mathrm{R}^{2}=0.95$ ), staying in line with recent findings (Table $\mathrm{S} 1$ ). 


\section{e. Weeds and other non-crop plants}

Given potential competition with crops, non-crop plants (e.g. arable weeds) are usually seen as enemies to yield and are therefore intensively fought with herbicides in conventional agriculture (Oerke, 2006). Widespread herbicide use has caused dramatic declines in arable plant species (Storkey et al., 2012), despite their importance as major basis for biodiversity and food webs, with bottom-up effects to insects and birds (Gerowitt et al., 2017). In Germany, 71\% of all arable plant species per crop field have disappeared since 1950 (Meyer et al., 2013) and currently 35\% of species are facing extinction (Albrecht et al., 2016). However, weeds are very diverse and some species may even exhibit net positive effects to agricultural systems thanks to a high biodiversity value and low levels of competition with crops (Marshall et al., 2003; Storkey, 2006). Beneficial weeds can decrease the damage caused by pests (Frank and Barone, 1999) and inhibit the proliferation of detrimental weeds and invasive plants, avoiding further costs for the farmers (Christina et al., 2015; Li et al., 2015; Vandermeer and Perfecto, 2017; Zhao et al., 2008).

The ability to distinguish and map beneficial and detrimental weeds within farms (see Storkey, 2006), can lead to a general reduction of herbicide application (Rasmussen et al., 2013) as farmers may opt to maintain beneficial weeds while removing detrimental ones. Selective herbicides constitute one method to achieve this. Alternatively, weed clusters could be treated at the sub-field level (Pelosi et al., 2015), exploiting the fact that weeds show often patchy distributions, naturally leaving a considerable proportion of land free of them (Rew and Cousens, 2001; Torres-Sánchez et al., 2013). Using a quadcopter equipped with a lightweight multispectral sensor, Peña et al. (2013) found that $23 \%$ of the area in a maize field was free of weeds, and the area with low weed coverage ( $<5 \%$ weeds) was $47 \%$. These findings highlight the potential of UAV-based weed mapping to reduce the amount and time spent on herbicide spraying (Table S1).

Satellites and airplanes are unsuitable for this task because of their low spatial and temporal resolutions (Lopez-Granados, 2011). Conversely, UAV-based imagery can capture the spectral differences between weeds, crop plants and bare soil enabling successful identification of weed plants (Peña et al., 2013), with accuracy levels of > 90\% (Pantazi et al., 2017; Peña et al., 2015). The success of these UAV operations in detecting weed plants has been shown to depend on the cameras used, resolution of images, as well as on time (i.e. days after sowing, Peña et al., 2015) . 
Accuracy can also be improved when crop row detection/classification is included in the identification process (Pérez-Ortiz et al., 2015).
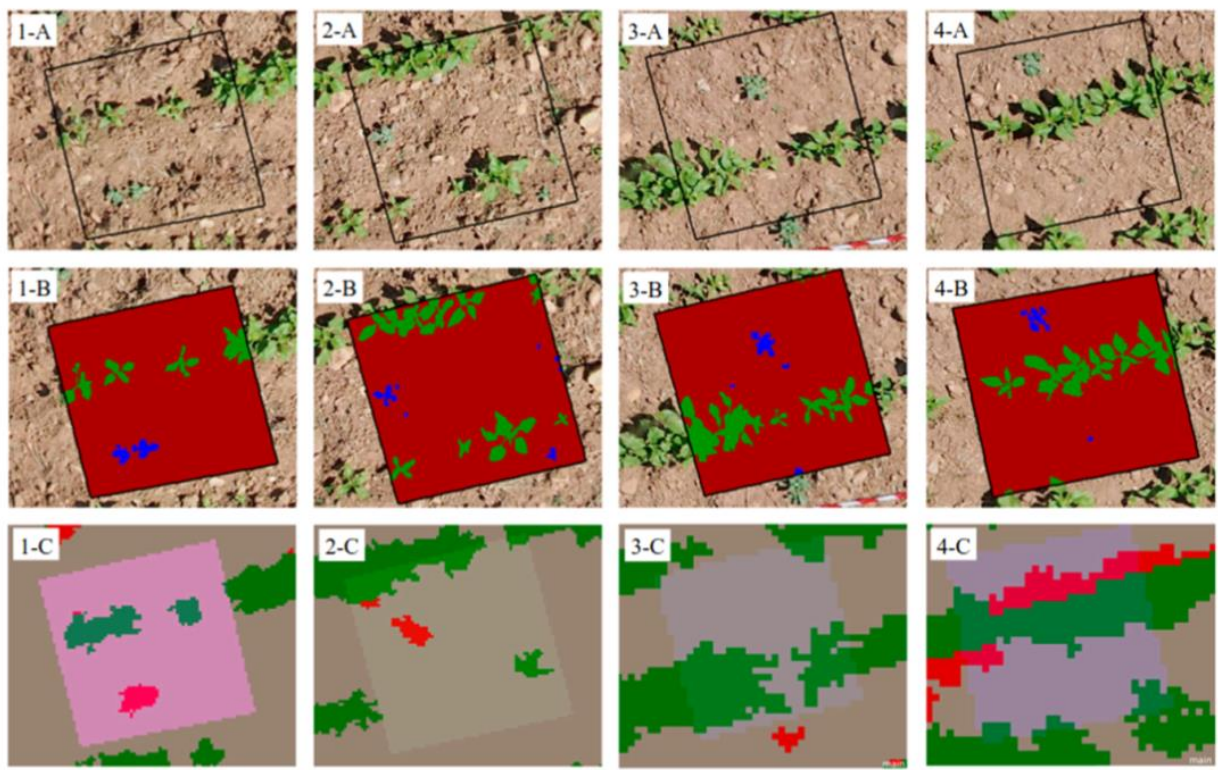

Fig. 3 Weed seedling detection in sunflower field from Spain (modified from Peña et al. (2015), used with permission). The first row includes on-ground photographs; the second shows manual classification of crop (green) and weeds (blue); and the third shows weed (red) and crop (green) detection with four different automatic classification methods (columns).

Precise weed detection has been shown to reduce herbicide applications ranging from $12.5 \%$ to 99\% depending on the proportion of the field infested, herbicide and application threshold used (Andújar et al., 2013; Hamouz et al., 2013). Castaldi et al. (2017), for example, used multispectral UAV imagery from a modified digital camera and demonstrated that UAVs can save up to $39 \%$ in herbicide applications in maize fields (Table S1). Furthermore, UAVs can be used to monitor weeds by taking air samples from wind-dispersed weed seeds (Shields et al., 2006). Finally, UAVs can assist in identifying detrimental weed seed predators (see section $1 \mathrm{~b}$ on animal diversity) such as certain insects, birds and small mammals (Bajwa et al., 2015), allowing for specific management practices for these species and therefore enhancing the provision of biological control services.

\section{Perspectives on future research}

Biodiversity-friendly management in agriculture has been limited by a lack of information on species location and condition, in particular if species cover large areas. Large-scale UAV 
applications will need collaboration between local and regional stakeholders to jointly take landscape scale measures. With current technology, UAV high spatial resolution imagery could be used to detect and map floral resources with high precision. Mapping and monitoring of flower resources from flower strips and set asides across landscapes is of major importance as these are fundamental for pollination and biological control services delivery (Sutter et al., 2018; Tschumi et al., 2015; Walton and Isaacs, 2011; Westphal et al., 2015). However, systematic monitoring of flower resources at the landscape scale in successive years has been practically unfeasible, given associated time and costs constrains.

UAVs' imagery, and in particular the emergent hyperspectral imaging from UAVs, opens a new set of possibilities for accurate mapping and monitoring of flower resources across entire landscapes by applying the spectral diversity/variability hypothesis. Additionally, multispectral sensors (especially those able to capture near-infra red radiation) could be used to provide a precise assessment of the activity and distribution of keystone animals (e.g. vertebrate pollinators, pests' predators and protected species), although arthropod activity is still mainly based on indirect evidence such as flower resources or plant damage (Xavier et al., 2018). UAV's imagery has therefore a promising potential to increase the efficacy of agri-environmental schemes across European agriculture (Batáry et al., 2011).

Despite the considerable advance in wildlife tracking in Ecology and Conservation Science this knowledge has not yet been extensively applied to identify species of agricultural or conservation value in agricultural landscapes. In particular, to our knowledge, pests' predators and crops' pollinators have not been so far systematically monitored in agricultural systems. Given the above we exhort scientists, state agencies and agricultural practitioners to put this new technology and knowledge at the service of biodiversity and ecosystem services conservation in agricultural landscapes.

In the tropics, where agricultural landscapes are usually complex mosaics of different crops and remnants of secondary tropical forest (Ribeiro et al., 2009), UAV's RGB and multispectral imagery could be further exploited to assess the conservation value and quality of forest fragments through biodiversity assessments from the over- and understorey (Getzin et al., 2012; Hernandez-Santin et al., 2019). This information can improve landscape management and contribute to policy making based on scientific evidence (Metzger, 2010). Moreover, the 
advances on UAV research will increase the number of native habitat fragments within agricultural landscapes that can be protected and allow further exploration of their interactions with cropland.

Premature and precise identification of crop damage due to pests and pathogens opens the possibility for a new set of tailored responses. Heavy, expensive and systemic pesticide application may become a method of the past as much cheaper, easier and biodiversity-friendly strategies can be applied, provided that pest damage is targeted early enough, before economic damage thresholds are reached. These strategies gain further importance considering the consistent move to insecticide and herbicide banning in developed countries (Storck et al., 2017). Additionally, systematic chemical control provokes emergence of resistant pest and weed (Schütte et al., 2017) populations, such as the Colorado potato beetle (Leptinotarsa decemlineata), which has developed resistance to $\geq 50$ different insecticides (Alyokhin et al., 2007; Mota-Sanchez et al., 2006). Therefore, reduced insecticide use means costs avoidance, preservation of yield enhancing pollinators (e.g. bees), and less contamination of soil and water (Arias-Estévez et al., 2008; Bretagnolle and Gaba, 2015; Geiger et al., 2010; Gerhardson, 2002; Potts et al., 2010; Wilson and Tisdell, 2001).

The detection of local and incipient pest focuses, such as those of the coffee-leaf-miner (Leucoptera coffeella) in coffee plantations, would become possible by identifying the particular necrotic areas caused in the leaves and may be mitigated by deployment or facilitation of natural enemies such as wasps, birds and bats (Librán-Embid et al., 2017). Identification of pest and pathogen presence in the agricultural landscape may also help to better understand how different land-use types and linear elements like flower strips and hedgerows affect their distribution. Control agents may then better contribute to a more biodiversity-friendly approach of pest and pathogen control in agricultural, natural and semi-natural land. Collaboration and coordination among local and regional stakeholders might become increasingly important under this scenario as many of these processes are affected by management at the local and landscape level (Redlich et al., 2018).

In general, conservation science has not yet fully integrated recent advances in plant monitoring coming out of precision agriculture, which could help to better monitor fragile ecosystems under climate change and biotic pressures. On the other hand, precision agriculture should incorporate 
the latest developments in species detection coming from conservation science, especially to distinguish among detrimental and beneficial arable weeds (see section 2e. weeds and other noncrop plants). This would benefit farmers' economy in terms of reduced time and herbicide costs, increased ecosystem services and would also contribute to the protection of biodiversity given the high proportion of arable weeds threatened with extinction (Albrecht et al., 2016; Meyer et al., 2013).

Yield is frequently negatively associated to biodiversity although management options to increase yield with less impact on biodiversity have been proposed (Clough et al., 2011; Cunningham et al., 2013). This apparent trade-off is, however, mainly caused by high agrochemical input associated to non-biodiversity-friendly agricultural intensification. We posit that UAVs can establish a new scenario in which the antipode between yield and biodiversity conservation may not be the rule. UAVs' based imagery is changing the way inputs are applied as it is allowing to identify where, when and how much input is needed with high precision. This produces two major benefits: first, yields increase as plants receive the exact treatment they need at the right time, avoiding nutrient, water and herbivory stress, and leading to reduced input costs for farmers. Second, reduced amounts of pesticides directly benefit naturally occurring insects (Geiger et al., 2010), which is not only fundamental for conservation science, but also increases the availability of beneficial agents such as pollinators and pest predators, thereby also reducing the necessity for inputs (Chaplin-Kramer et al., 2011; Cohen et al., 1994; Holland et al., 2012). In sum, these developments may constitute a synergistic win-win scenario.

\section{Conclusions}

Future agricultural landscapes must meet two major objectives: 1) increase food, fiber and fuel production and 2) do so in a biodiversity-friendly way. Here we show that UAVs are helping to reconcile these oft-considered discrepant objectives, by enhancing the efficiency of fertilizer, pesticide and herbicide applications, while simultaneously increasing yield and reducing impacts on biodiversity. UAV-based information on species' habitat use and movement through the landscape supports more efficient large-scale management of beneficial animals and increased success in biological conservation. Therefore, UAVs are expected to become common tools for the management of agricultural landscapes, in particular when combined with promising developing technology, such as light-weight hyperspectral sensors. UAV-based imagery will not substitute the use of manned aircraft or satellite imagery for regional and global assessments but 
will greatly contribute to local management at small to medium scales (up to 50 ha). The main current limitations for a more widespread adoption of UAVs are the high price of multispectral and especially hyperspectral sensors; the lack of established image processing methods in some applications; and the lower estimation accuracy for yield estimations in certain crops, compared to traditional methods. Nevertheless, these current limitations may be offset in the near future by rapid advances in sensor technology and decreasing prices, thereby increasing the suitability of UAVs for applications in agriculture and conservation science.

\section{Acknowledgments}

This research was supported by the German Research Association (DFG) Research Training Group 1644 "Scaling Problems in Statistics", grant no. 152112243. We thank two anonymous reviewers and the editor for the valuable comments that improved the manuscript. Our gratitude goes also to Emmeline Topp, Kevin Li and Carolina Ocampo Ariza for proofreading the manuscript.

\section{References}

Acevo-Herrera R, Aguasca A, Bosch-Lluis X, Camps A, Martínez-Fernández J, Sánchez-Martín $\mathrm{N}$ et al. Design and First Results of an UAV-Borne L-Band Radiometer for Multiple Monitoring Purposes. Remote Sensing 2010;2(7):1662-79.

Adão T, Hruška J, Pádua L, Bessa J, Peres E, Morais R et al. Hyperspectral Imaging: A Review on UAV-Based Sensors, Data Processing and Applications for Agriculture and Forestry. Remote Sensing 2017;9(11):1110.

Ahmed OS, Shemrock A, Chabot D, Dillon C, Williams G, Wasson R et al. Hierarchical land cover and vegetation classification using multispectral data acquired from an unmanned aerial vehicle. International Journal of Remote Sensing 2017;38(8-10):2037-52.

Albrecht H, Cambecèdes J, Lang M, Wagner M. Management options for the conservation of rare arable plants in Europe. Botany Letters 2016;163(4):389-415.

Aldana Jague E, Sommer M, Saby NPA, Cornelis J-T, van Wesemael B, van Oost K. High resolution characterization of the soil organic carbon depth profile in a soil landscape affected by erosion. Soil and Tillage Research 2016a;156:185-93.

Aldana-Jague E, Heckrath G, Macdonald A, van Wesemael B, van Oost K. UAS-based soil carbon mapping using VIS-NIR (480-1000nm) multi-spectral imaging: Potential and limitations. GEODERMA 2016b;275:55-66. 
Alyokhin A, Dively G, Patterson M, Castaldo C, Rogers D, Mahoney M et al. Resistance and cross-resistance to imidacloprid and thiamethoxam in the Colorado potato beetle Leptinotarsa decemlineata. Pest Management Science: formerly Pesticide Science 2007;63(1):32-41.

Anderson K, Gaston KJ. Lightweight unmanned aerial vehicles will revolutionize spatial ecology. Frontiers in Ecology and the Environment 2013;11(3):138-46.

Andújar D, Ribeiro A, Fernández-Quintanilla C, Dorado J. Herbicide savings and economic benefits of several strategies to control Sorghum halepense in maize crops. Crop Protection 2013;50:17-23.

Arias-Estévez M, López-Periago E, Martínez-Carballo E, Simal-Gándara J, Mejuto J-C, GarcíaRío L. The mobility and degradation of pesticides in soils and the pollution of groundwater resources. Agriculture, Ecosystems \& Environment 2008;123(4):247-60.

Association for Computing Machinery. Compact Hyperspectral Imaging at Low Cost, 2017. https://www.rdmag.com/news/2017/12/compact-hyperspectral-imaging-low-cost (accessed March 10, 2019).

Baena S, Moat J, Whaley O, Boyd DS. Identifying species from the air: UAVs and the very high resolution challenge for plant conservation. PloS one 2017;12(11):e0188714.

Bajwa AA, Mahajan G, Chauhan BS. Nonconventional Weed Management Strategies for Modern Agriculture. Weed sci. 2015;63(04):723-47.

Balvanera P, Pfisterer AB, Buchmann N, He J-S, Nakashizuka T, Raffaelli D et al. Quantifying the evidence for biodiversity effects on ecosystem functioning and services. Ecology letters 2006;9(10):1146-56.

Bareth G, Aasen H, Bendig J, Gnyp ML, Bolten A, Jung A et al. Low-weight and UAV-based Hyperspectral Full-frame Cameras for Monitoring Crops: Spectral Comparison with Portable Spectroradiometer Measurements. Photogrammetrie - Fernerkundung Geoinformation 2015(1):69-79.

Bareth G, Bendig J, Tilly N, Hoffmeister D, Aasen H, Bolten A. A Comparison of UAV-and TLS-derived Plant Height for Crop Monitoring: Using Polygon Grids for the Analysis of Crop Surface Models (CSMs). Photogrammetrie - Fernerkundung - Geoinformation 2016;2016(2):85-94.

Barrera JF. Coffee pests and their management. Encyclopedia of entomology 2008:961-98.

Batáry P, Báldi A, Kleijn D, Tscharntke T. Landscape-moderated biodiversity effects of agrienvironmental management: A meta-analysis. Proceedings. Biological sciences 2011;278(1713):1894-902. 
Batáry P, Dicks LV, Kleijn D, Sutherland WJ. The role of agri-environment schemes in conservation and environmental management. Conservation biology the journal of the Society for Conservation Biology 2015;29(4):1006-16.

Bazzoffi P. Measurement of rill erosion through a new UAV-GIS methodology. Ital J Agronomy 2015;10(1s).

Bendig J, Bolten A, Bennertz S, Broscheit J, Eichfuss S, Bareth G. Estimating Biomass of Barley Using Crop Surface Models (CSMs) Derived from UAV-Based RGB Imaging. Remote Sensing 2014;6(11):10395-412.

Bertacchi A, Giannini V, Di Franco C, Silvestri N. Using unmanned aerial vehicles for vegetation mapping and identification of botanical species in wetlands. LANDSCAPE AND ECOLOGICAL ENGINEERING 2019;15(2):231-40.

Boesing AL, Nichols E, Metzger JP. Effects of landscape structure on avian-mediated insect pest control services: A review. Landscape Ecol 2017;32(5):931-44.

Boesing AL, Nichols E, Metzger JP. Biodiversity extinction thresholds are modulated by matrix type. ECOGRAPHY 2018;41(9):1520-33.

Bongiovanni R, Lowenberg-Deboer J. Precision Agriculture and Sustainability. Precision Agriculture 2004;5(4):359-87.

Bora GC, Nowatzki JF, Roberts DC. Energy savings by adopting precision agriculture in rural USA. Energ Sustain Soc 2012;2(1):22.

Bourguet D, Guillemaud T. The Hidden and External Costs of Pesticide Use. In: Lichtfouse E, editor. Sustainable agriculture reviews. Cham: SPRINGER; 2016. p. 35-120.

Breckenridge RP, Dakins M, Bunting S, Harbour JL, Lee RD. Using Unmanned Helicopters to Assess Vegetation Cover in Sagebrush Steppe Ecosystems. RANGELAND ECOLOGY \& MANAGEMENT 2012;65(4):362-70.

Bretagnolle V, Gaba S. Weeds for bees?: A review. Agron. Sustain. Dev. 2015;35(3):891-909.

Calderón R, Montes-Borrego M, Landa BB, Navas-Cortés JA, Zarco-Tejada PJ. Detection of downy mildew of opium poppy using high-resolution multi-spectral and thermal imagery acquired with an unmanned aerial vehicle. Precision Agric 2014;15(6):639-61.

Cao J, Liu K, Zhu Y, Li J, He Z. Identifying Mangrove Species Using Field Close-Range Snapshot Hyperspectral Imaging and Machine-Learning Techniques. Remote Sensing 2018;10(12):2047. 
Capolupo A, Kooistra L, Berendonk C, Boccia L, Suomalainen J. Estimating Plant Traits of Grasslands from UAV-Acquired Hyperspectral Images: A Comparison of Statistical Approaches. IJGI 2015;4(4):2792-820.

Cardil A, Vepakomma U, Brotons L. Assessing Pine Processionary Moth Defoliation Using Unmanned Aerial Systems. FORESTS 2017;8(10):402.

Castaldi F, Pelosi F, Pascucci S, Casa R. Assessing the potential of images from unmanned aerial vehicles (UAV) to support herbicide patch spraying in maize. Precision Agric 2017;18(1):76-94.

$\begin{array}{llllll}\text { CBRNE } & \text { Tech } & \text { Index. } & \text { Hyperspectral Imaging }\end{array}$ http://www.cbrnetechindex.com/Chemical-Detection/Technology-CD/MolecularSpectroscopy-CD-T/Hyperspectral-Imaging-CD-MS (accessed March 10, 2019).

Chaplin-Kramer R, O'Rourke ME, Blitzer EJ, Kremen C. A meta-analysis of crop pest and natural enemy response to landscape complexity. Ecology letters 2011;14(9):922-32.

Chen Q, Vaglio Laurin G, Battles JJ, Saah D. Integration of airborne lidar and vegetation types derived from aerial photography for mapping aboveground live biomass. Remote Sensing of Environment 2012;121:108-17.

Chen S, F Laefer D, Mangina E. State of technology review of civilian UAVs. Recent Patents on Engineering 2016;10(3):160-74.

Chrétien L-P, Théau J, Ménard P. Visible and thermal infrared remote sensing for the detection of white-tailed deer using an unmanned aerial system. Wildl. Soc. Bull. 2016;40(1):18191.

Christina M, Rouifed S, Puijalon S, Vallier F, Meiffren G, Bellvert F et al. Allelopathic effect of a native species on a major plant invader in Europe. Die Naturwissenschaften 2015;102(34): 12.

Clough Y, Barkmann J, Juhrbandt J, Kessler M, Wanger TC, Anshary A et al. Combining high biodiversity with high yields in tropical agroforests. PROCEEDINGS OF THE NATIONAL ACADEMY OF SCIENCES OF THE UNITED STATES OF AMERICA 2011;108(20):8311-6.

Cochrane MA. Using vegetation reflectance variability for species level classification of hyperspectral data. International Journal of Remote Sensing 2000;21(10):2075-87.

Cohen JE, Schoenly K, Heong KL, Justo H, Arida G, Barrion AT et al. A food web approach to evaluating the effect of insecticide spraying on insect pest population dynamics in a Philippine irrigated rice ecosystem. J Appl Ecol 1994:747-63. 
Colomina I, Molina P. Unmanned aerial systems for photogrammetry and remote sensing: A review. ISPRS Journal of Photogrammetry and Remote Sensing 2014;92:79-97.

Crucil G, Castaldi F, Aldana-Jague E, van Wesemael B, Macdonald A, van Oost K. Assessing the Performance of UAS-Compatible Multispectral and Hyperspectral Sensors for Soil Organic Carbon Prediction. SUSTAINABILITY 2019;11(7).

Cruzan MB, Weinstein BG, Grasty MR, Kohrn BF, Hendrickson EC, Arredondo TM et al. Small unmanned aerial vehicles (micro-UAVs, drones) in plant ecology. Applications in plant sciences 2016;4(9).

Cukor J, Bartoška J, Rohla J, Sova J, Machálek A. Use of aerial thermography to reduce mortality of roe deer fawns before harvest. PeerJ 2019;7:e6923.

Cunningham SA, Attwood SJ, Bawa KS, Benton TG, Broadhurst LM, Didham RK et al. To close the yield-gap while saving biodiversity will require multiple locally relevant strategies. Agriculture, Ecosystems \& Environment 2013;173:20-7.

Dandois JP, Ellis EC. High spatial resolution three-dimensional mapping of vegetation spectral dynamics using computer vision. Remote Sensing of Environment 2013;136:259-76.

del-Campo-Sanchez A, Ballesteros R, Hernandez-Lopez D, Fernando Ortega J, Moreno MA, Agroforestry Cartography Precision. Quantifying the effect of Jacobiasca lybica pest on vineyards with UAVs by combining geometric and computer vision techniques. PloS one 2019;14(4).

Deutsch CA, Tewksbury JJ, Tigchelaar M, Battisti DS, Merrill SC, Huey RB et al. Increase in crop losses to insect pests in a warming climate. Science (New York, N.Y.) 2018;361(6405):916-9.

d'Oleire-Oltmanns S, Marzolff I, Peter K, Ries J. Unmanned Aerial Vehicle (UAV) for Monitoring Soil Erosion in Morocco. Remote Sensing 2012;4(11):3390-416.

Dufour S, Bernez I, Betbeder J, Corgne S, Hubert-Moy L, Nabucet J et al. Monitoring restored riparian vegetation: How can recent developments in remote sensing sciences help? KNOWLEDGE AND MANAGEMENT OF AQUATIC ECOSYSTEMS 2013(410).

Egan JF, Bohnenblust E, Goslee S, Mortensen D, Tooker J. Herbicide drift can affect plant and arthropod communities. AGRICULTURE ECOSYSTEMS \& ENVIRONMENT 2014;185:77-87.

Estrany, J., Ruiz, M., Calsamiglia, A., Carriquí, M., García-Comendador, J., Nadal, M., Gago, J., 2019. Sediment connectivity linked to vegetation using UAVs: High-resolution im- agery for ecosystem management. Sci. Total Environ. 671, 1192-1205. 
Fahrig L. Ecological Responses to Habitat Fragmentation Per Se. Annu. Rev. Ecol. Evol. Syst. 2017;48(1):1-23.

Faithpraise F, Idung J, Chatwin C, Young R, Birch P. Modelling the control of African Armyworm (Spodoptera exempta) infestations in cereal crops by deploying naturally beneficial insects. Biosystems Engineering 2015;129:268-76.

Faye, E., Rebaudo, F., Yánez-Cajo, D., Cauvy-Fraunié, S., Dangles, O., 2016. A toolbox for studying thermal heterogeneity across spatial scales: from unmanned aerial vehicle imagery to landscape metrics. Methods Ecol. Evol. 7 (4), 437-446.

Forbey JS, Patricelli GL, Delparte DM, Krakauer AH, Olsoy PJ, Fremgen MR et al. Emerging technology to measure habitat quality and behavior of grouse: Examples from studies of greater sage-grouse. Wildlife Biology 2017:wlb.00238.

Frank T, Barone M. Short-term field study on weeds reducing slug feeding on oilseed rape. ZEITSCHRIFT FUR PFLANZENKRANKHEITEN UND PFLANZENSCHUTZJOURNAL OF PLANT DISEASES AND PROTECTION 1999;106(5):534-8.

Gago J, Douthe C, Coopman RE, Gallego PP, Ribas-Carbo M, Flexas J et al. UAVs challenge to assess water stress for sustainable agriculture. Agricultural Water Management 2015;153:9-19.

Gao T, Yang X, Jin Y, Ma H, Li J, Yu H et al. Spatio-temporal variation in vegetation biomass and its relationships with climate factors in the Xilingol grasslands, Northern China. PloS one $2013 ; 8(12):$ e83824.

García-Feced C, Weissteiner CJ, Baraldi A, Paracchini ML, Maes J, Zulian G et al. Semi-natural vegetation in agricultural land: European map and links to ecosystem service supply. Agron. Sustain. Dev. 2015;35(1):273-83.

Garcia-Ruiz F, Sankaran S, Maja JM, Lee WS, Rasmussen J, Ehsani R. Comparison of two aerial imaging platforms for identification of Huanglongbing-infected citrus trees. COMPUTERS AND ELECTRONICS IN AGRICULTURE 2013;91:106-15.

Garibaldi LA, Steffan-Dewenter I, Winfree R, Aizen MA, Bommarco R, Cunningham SA et al. Wild pollinators enhance fruit set of crops regardless of honey bee abundance. Science (New York, N.Y.) 2013;339(6127):1608-11.

Ge X, Wang J, Ding J, Cao X, Zhang Z, Liu J et al. Combining UAV-based hyperspectral imagery and machine learning algorithms for soil moisture content monitoring. PeerJ $2019 ; 7$. 
Gebbers R, Adamchuk VI. Precision Agriculture and Food Security. SCIENCE 2010;327(5967):828-31.

Geiger F, Bengtsson J, Berendse F, Weisser WW, Emmerson M, Morales MB et al. Persistent negative effects of pesticides on biodiversity and biological control potential on European farmland. Basic and Applied Ecology 2010;11(2):97-105.

Geipel J, Link J, Claupein W. Combined Spectral and Spatial Modeling of Corn Yield Based on Aerial Images and Crop Surface Models Acquired with an Unmanned Aircraft System. Remote Sensing 2014;6(11):10335-55.

Gerhardson B. Biological substitutes for pesticides. Trends in Biotechnology 2002;20(8):338-43.

Gerling D, Alomar Ò, Arnò J. Biological control of Bemisia tabaci using predators and parasitoids. Crop Protection 2001;20(9):779-99.

Gerowitt B, Bàrberi P, Darmency H, Petit S, Storkey J, Westerman P. Weeds and Biodiversity: Expanding Horizons. In: ; 2017. p. 115-147.

Getzin S, Wiegand K, Schöning I. Assessing biodiversity in forests using very high-resolution images and unmanned aerial vehicles. METHODS IN ECOLOGY AND EVOLUTION 2012;3(2):397-404.

Gill RJ, Ramos-Rodriguez O, Raine NE. Combined pesticide exposure severely affects individual-and colony-level traits in bees. Nature 2012;491(7422):105.

Goebel ME, Perryman WL, Hinke JT, Krause DJ, Hann NA, Gardner S et al. A small unmanned aerial system for estimating abundance and size of Antarctic predators. Polar Biol 2015;38(5):619-30.

Gong Y, Duan B, Fang S, Zhu R, Wu X, Ma Y et al. Remote estimation of rapeseed yield with unmanned aerial vehicle (UAV) imaging and spectral mixture analysis. Plant methods 2018;14:70.

Gonzalez LF, Montes GA, Puig E, Johnson S, Mengersen K, Gaston KJ. Unmanned Aerial Vehicles (UAVs) and Artificial Intelligence Revolutionizing Wildlife Monitoring and Conservation. Sensors (Basel, Switzerland) 2016;16(1).

Grass et al. Land-sharing/-sparing connectivity landscapes for biodiversity services and conservation 2019.

Gross JW, Heumann BW. Can flowers provide better spectral discrimination between herbaceous wetland species than leaves? Remote Sensing Letters 2014;5(10):892-901.

Grüner E, Astor T, Wachendorf M. Biomass Prediction of Heterogeneous Temperate Grasslands Using an SfM Approach Based on UAV Imaging. Agronomy 2019;9(2):54. 
Guerra-Hernández, J., González-Ferreiro, E., Monleón, V.J., Faias, S.P., Tomé, M., Díaz-Varela, R.A., 2017. Use of multi-temporal UAV-derived imagery for estimating individual tree growth in Pinus pinea stands. Forests 8 (8), 300.

Habel JC, Teucher M, Ulrich W, Bauer M, Rödder D. Drones for butterfly conservation: Larval habitat assessment with an unmanned aerial vehicle. Landscape Ecol 2016;31(10):238595.

Hamouz P, Hamouzova K, Holec J, Tyser L. Impact of site-specific weed management on herbicide savings and winter wheat yield. PLANT SOIL AND ENVIRONMENT 2013;59(3):101-7.

Hernandez-Santin L, Rudge M, Bartolo R, Erskine P. Identifying Species and Monitoring Understorey from UAS-Derived Data: A Literature Review and Future Directions. Drones 2019;3(1):9.

Heumann BW, Hackett RA, Monfils AK. Testing the spectral diversity hypothesis using spectroscopy data in a simulated wetland community. Ecological Informatics 2015;25:29_ 34.

Hodgson, J.C., Baylis, S.M., Mott, R., Herrod, A., Clarke, R.H., 2016. Precision wildlife monitoring using unmanned aerial vehicles. Sci. Rep. 6 (1), 1-7.

Holland JM, Oaten H, Moreby S, Birkett T, Simper J, Southway S et al. Agri-environment scheme enhancing ecosystem services: A demonstration of improved biological control in cereal crops. Agriculture, Ecosystems \& Environment 2012;155:147-52.

Hooper DU, Adair EC, Cardinale BJ, Byrnes JEK, Hungate BA, Matulich KL et al. A global synthesis reveals biodiversity loss as a major driver of ecosystem change. Nature 2012;486(7401):105.

Israel M, Reinhard A. Detecting nests of lapwing birds with the aid of a small unmanned aerial vehicle with thermal camera. In: 2017 International Conference on Unmanned Aircraft Systems (ICUAS); 6/13/2017 - 6/16/2017: Miami, FL, USA. [S.1.]: IEEE; 2017 - 2017.

Ivosevic B, Yong-Gu H, Ohseok K. Monitoring butterflies with an unmanned aerial vehicle: current possibilities and future potentials. Journal of Ecology and Environment 2017;41(1):12.

Jay S, Baret F, Dutartre D, Malatesta G, Héno S, Comar A et al. Exploiting the centimeter resolution of UAV multispectral imagery to improve remote-sensing estimates of canopy structure and biochemistry in sugar beet crops. Remote Sensing of Environment $2019 ; 231$. https://www.scopus.com/inward/record.uri?eid=2-s2.0- 
85053698499\&doi=10.1016\%2fj.rse.2018.09.011\&partnerID=40\&md5=f8b8b6e5b9b68b $4 \mathrm{e} 93 \mathrm{e} 4701 \mathrm{eba3c6120.}$

Jong FMW de, Snoo GR de, van de Zande, Jan C. Estimated nationwide effects of pesticide spray drift on terrestrial habitats in the Netherlands. Journal of environmental management 2008;86(4):721-30.

Kachamba D, Ørka H, Næsset E, Eid T, Gobakken T. Influence of Plot Size on Efficiency of Biomass Estimates in Inventories of Dry Tropical Forests Assisted by Photogrammetric Data from an Unmanned Aircraft System. Remote Sensing 2017;9(6):610.

Kalisperakis I, Stentoumis C, Grammatikopoulos L, Karantzalos K. LEAF AREA INDEX ESTIMATION IN VINEYARDS FROM UAV HYPERSPECTRAL DATA, 2D IMAGE MOSAICS AND 3D CANOPY SURFACE MODELS. Int. Arch. Photogramm. Remote Sens. Spatial Inf. Sci. 2015;XL-1/W4:299-303.

Kavoosi Z, Raoufat MH, Dehghani M, Abdolabbas J, Kazemeini SA, Nazemossadat MJ. Feasibility of satellite and drone images for monitoring soil residue cover. Journal of the Saudi Society of Agricultural Sciences 2018.

Khaliq A, Comba L, Biglia A, Aimonino DR, Chiaberge M, Gay P. Comparison of Satellite and UAV-Based Multispectral Imagery for Vineyard Variability Assessment. Remote Sensing 2019;11(4).

Klein A-M, Vaissière BE, Cane JH, Steffan-Dewenter I, Cunningham SA, Kremen C et al. Importance of pollinators in changing landscapes for world crops. PROCEEDINGS OF THE ROYAL SOCIETY B-BIOLOGICAL SCIENCES 2007;274(1608):303-13.

Klingner R, Richter K, Schmolz E, Keller B. The role of moisture in the nest thermoregulation of social wasps. The Science of Nature 2005;92(9):427-30.

Knoth C, Klein B, Prinz T, Kleinebecker T. Unmanned aerial vehicles as innovative remote sensing platforms for high-resolution infrared imagery to support restoration monitoring in cut-over bogs. Applied Vegetation Science 2013;16(3):509-17.

Kremen C, Merenlender AM. Landscapes that work for biodiversity and people. Science (New York, N.Y.) 2018;362(6412).

Kremen C, Williams NM, Aizen MA, Gemmill-Herren B, LeBuhn G, Minckley R et al. Pollination and other ecosystem services produced by mobile organisms: A conceptual framework for the effects of land-use change. Ecology letters 2007;10(4):299-314.

Kumar SV, Dirmeyer PA, Peters-Lidard CD, Bindlish R, Bolten J. Information theoretic evaluation of satellite soil moisture retrievals. Remote Sensing of Environment 2018;204:392-400. 
Kunz TH, Braun de Torrez E, Bauer D, Lobova T, Fleming TH. Ecosystem services provided by bats. Annals of the New York Academy of Sciences 2011;1223(1):1-38.

Laamrani A, Berg AA, Voroney P, Feilhauer H, Blackburn L, March M et al. Ensemble identification of spectral bands related to soil organic carbon levels over an agricultural field in southern Ontario, Canada. Remote Sensing 2019;11(11).

Landis DA, Wratten SD, Gurr GM. Habitat management to conserve natural enemies of arthropod pests in agriculture. ANNUAL REVIEW OF ENTOMOLOGY 2000;45:175201.

Lange R de, van Til M, Dury S. The use of hyperspectral data in coastal zone vegetation monitoring. EARSeL eProceedings 2004;3(2):143-53.

Lelong CCD, Burger P, Jubelin G, Roux B, Labbé S, Baret F. Assessment of Unmanned Aerial Vehicles Imagery for Quantitative Monitoring of Wheat Crop in Small Plots. Sensors (Basel, Switzerland) 2008;8(5):3557-85.

Li W, Luo J, Tian X, Soon Chow W, Sun Z, Zhang T et al. A new strategy for controlling invasive weeds: Selecting valuable native plants to defeat them. Scientific reports 2015;5:11004.

Li W, Niu Z, Chen H, Li D, Wu M, Zhao W. Remote estimation of canopy height and aboveground biomass of maize using high-resolution stereo images from a low-cost unmanned aerial vehicle system. Ecological Indicators 2016;67:637-48.

Liang T, Yang S, Feng Q, Liu B, Zhang R, Huang X et al. Multi-factor modeling of aboveground biomass in alpine grassland: A case study in the Three-River Headwaters Region, China. Remote Sensing of Environment 2016;186:164-72.

Librán-Embid F, Coster G de, Metzger JP. Effects of bird and bat exclusion on coffee pest control at multiple spatial scales. Landscape Ecol 2017;32(9):1907-20.

Lichtenthaler HK. The stress concept in plants: An introduction. Annals of the New York Academy of Sciences 1998;851:187-98.

Lim P-C, Kim T, Na S-I, Lee K-D, Ahn H-Y, Hong J. Analysis of UAV image Quality using Edge Analysis. International Archives of the Photogrammetry, Remote Sensing \& Spatial Information Sciences 2018;42(4).

Liu S, Li L, Gao W, Zhang Y, Liu Y, Wang S et al. Diagnosis of nitrogen status in winter oilseed rape (Brassica napus L.) using in-situ hyperspectral data and unmanned aerial vehicle (UAV) multispectral images. COMPUTERS AND ELECTRONICS IN AGRICULTURE 2018;151:185-95. 
Lopatin J, Fassnacht FE, Kattenborn T, Schmidtlein S. Mapping plant species in mixed grassland communities using close range imaging spectroscopy. Remote Sensing of Environment 2017;201:12-23.

López-Bermúdez F. Soil erosion by water on the desertification of a semi-arid Mediterranean fluvial basin: the Segura basin, Spain 1990.

Lopez-Granados F. Weed detection for site-specific weed management: Mapping and real-time approaches. Weed Res 2011;51(1):1-11.

López-López M, Calderón R, González-Dugo V, Zarco-Tejada P, Fereres E. Early Detection and Quantification of Almond Red Leaf Blotch Using High-Resolution Hyperspectral and Thermal Imagery. Remote Sensing 2016;8(4):276.

López-Lozano R, Casterad MA. Comparison of different protocols for indirect measurement of leaf area index with ceptometers in vertically trained vineyards. Australian Journal of Grape and Wine Research 2013;19(1):116-22.

Lu B, He Y. Species classification using Unmanned Aerial Vehicle (UAV)-acquired high spatial resolution imagery in a heterogeneous grassland. ISPRS Journal of Photogrammetry and Remote Sensing 2017;128:73-85.

Maas B, Tscharntke T, Saleh S, Dwi Putra D, Clough Y. Avian species identity drives predation success in tropical cacao agroforestry. J Appl Ecol 2015;52(3):735-43.

Maes WH, Steppe K. Perspectives for Remote Sensing with Unmanned Aerial Vehicles in Precision Agriculture. TRENDS IN PLANT SCIENCE 2019;24(2):152-64.

Mafanya M, Tsele P, Botai J, Manyama P, Swart B, Monate T. Evaluating pixel and object based image classification techniques for mapping plant invasions from UAV derived aerial imagery: Harrisia pomanensis as a case study. ISPRS Journal of Photogrammetry and Remote Sensing 2017;129:1-11.

Magioli M, Ferraz KMPM de, Setz EZF, Percequillo AR, Rondon MVdSS, Kuhnen VV et al. Connectivity maintain mammal assemblages functional diversity within agricultural and fragmented landscapes. Eur J Wildl Res 2016;62(4):431-46.

Mahlein A-K. Plant Disease Detection by Imaging Sensors - Parallels and Specific Demands for Precision Agriculture and Plant Phenotyping. PLANT DISEASE 2016;100(2):241-51.

Mahlein A-K, Kuska MT, Behmann J, Polder G, Walter A. Hyperspectral Sensors and Imaging Technologies in Phytopathology: State of the Art. Annual review of phytopathology 2018;56:535-58. 
Maimaitiyiming M, Ghulam A, Bozzolo A, Wilkins JL, Kwasniewski MT. Early Detection of Plant Physiological Responses to Different Levels of Water Stress Using Reflectance Spectroscopy. Remote Sensing 2017;9(7).

Malenovský Z, Lucieer A, King DH, Turnbull JD, Robinson SA, Lecomte N. Unmanned aircraft system advances health mapping of fragile polar vegetation. Methods Ecol Evol 2017;8(12):1842-57.

Mapfumo RB, Murwira A, Masocha M, Andriani R. The relationship between satellite-derived indices and species diversity across African savanna ecosystems. International Journal of Applied Earth Observation and Geoinformation 2016;52:306-17.

Marshall EJP, Brown VK, Boatman ND, Lutman PJW, Squire GR, Ward LK. The role of weeds in supporting biological diversity within crop fields*. Weed Res 2003;43(2):77-89.

Matese A, Toscano P, Di Gennaro SF, Genesio L, Vaccari FP, Primicerio J et al. Intercomparison of UAV, Aircraft and Satellite Remote Sensing Platforms for Precision Viticulture. Remote Sensing 2015;7(3):2971-90.

Medeiros HR, Grandinete YC, Manning P, Harper KA, Cutler GC, Tyedmers P et al. Forest cover enhances natural enemy diversity and biological control services in Brazilian sun coffee plantations. Agron. Sustain. Dev. 2019;39(6):21.

Metzger JP, Bustamante MMC, Ferreira J, Fernandes GW, Librán-Embid F, Pillar VD et al. Why Brazil needs its Legal Reserves. Perspec. in Ecol. and Cons. 2019; 17(3):91-103.

Meyer S, Wesche K, Krause B, Leuschner C, Rejmanek M. Dramatic losses of specialist arable plants in Central Germany since the 1950s/60s - a cross-regional analysis. Diversity Distrib. 2013;19(9):1175-87.

Michez A, Piégay H, Lisein J, Claessens H, Lejeune P. Classification of riparian forest species and health condition using multi-temporal and hyperspatial imagery from unmanned aerial system. Environmental monitoring and assessment 2016;188(3):146.

Möckel T, Dalmayne J, Schmid B, Prentice H, Hall K. Airborne Hyperspectral Data Predict FineScale Plant Species Diversity in Grazed Dry Grasslands. Remote Sensing 2016;8(2):133.

Mora C, Vieira G, Pina P, Lousada M, Christiansen HH. Land Cover Classification Using HighResolution Aerial Photography in Adventdalen, Svalbard. GEOGRAFISKA ANNALER SERIES A-PHYSICAL GEOGRAPHY 2015;97(3):473-88.

Moriya EAS, Imai NN, Tommaselli AMG, Miyoshi GT. Mapping Mosaic Virus in Sugarcane Based on Hyperspectral Images. IEEE J. Sel. Top. Appl. Earth Observations Remote Sensing 2017;10(2):740-8. 
Mota-Sanchez D, Hollingworth RM, Grafius EJ, Moyer DD. Resistance and cross-resistance to neonicotinoid insecticides and spinosad in the Colorado potato beetle, Leptinotarsa decemlineata (Say)(Coleoptera: Chrysomelidae). Pest Management Science: formerly Pesticide Science 2006;62(1):30-7.

Mozumder P, Berrens RP. Inorganic fertilizer use and biodiversity risk: An empirical investigation. Ecological Economics 2007;62(3-4):538-43.

Mulero-Pázmány M, Negro JJ, editors. Small UAS for Montagus Harriers (Circus pygargus) nests monitoring; Seville, Spain: University of Engineering; 2011.

Mulla DJ. Twenty five years of remote sensing in precision agriculture: Key advances and remaining knowledge gaps. Biosystems Engineering 2013;114(4):358-71.

Nemeskéri E, Molnár K, Rácz C, Dobos A, Helyes L. Effect of Water Supply on Spectral Traits and Their Relationship with the Productivity of Sweet Corns. Agronomy 2019;9(2):63.

Nevala NE, Baden T. A low-cost hyperspectral scanner for natural imaging above and under water; 2018.

Oerke E-C. Crop losses to pests. J. Agric. Sci. 2006;144(1):31-43.

Oerke E-C, Steiner U, Dehne H-W, Lindenthal M. Thermal imaging of cucumber leaves affected by downy mildew and environmental conditions. JOURNAL OF EXPERIMENTAL BOTANY 2006;57(9):2121-32.

Oliveira CM, Auad AM, Mendes SM, Frizzas MR. Crop losses and the economic impact of insect pests on Brazilian agriculture. Crop Protection 2014;56:50-4.

Ollerton J, Winfree R, Tarrant S. How many flowering plants are pollinated by animals? OIKOS 2011;120(3):321-6.

Pádua L, Vanko J, Hruška J, Adão T, Sousa JJ, Peres E et al. UAS, sensors, and data processing in agroforestry: A review towards practical applications. International Journal of Remote Sensing 2017;38(8-10):2349-91.

Pajares G. Overview and Current Status of Remote Sensing Applications Based on Unmanned Aerial Vehicles (UAVs). Photogram Engng Rem Sens 2015;81(4):281-330.

Palmer MW, Earls PG, Hoagland BW, White PS, Wohlgemuth T. Quantitative tools for perfecting species lists. Environmetrics 2002;13(2):121-37.

Pantazi XE, Tamouridou AA, Alexandridis TK, Lagopodi AL, Kashefi J, Moshou D. Evaluation of hierarchical self-organising maps for weed mapping using UAS multispectral imagery. COMPUTERS AND ELECTRONICS IN AGRICULTURE 2017;139:224-30. 
Paul C, Hanley N, Meyer ST, Fürst C, Weisser WW, Knoke T. On the functional relationship between biodiversity and economic value. Science Advances 2020;6(5):eaax7712.

Pelosi F, Castaldi F, Casa R. Operational unmanned aerial vehicle assisted post-emergence herbicide patch spraying in maize: A field study. In: Precision agriculture'15: Wageningen Academic Publishers; 2015. p. 31-38.

Peña JM, Torres-Sánchez J, Castro AI de, Kelly M, López-Granados F. Weed mapping in earlyseason maize fields using object-based analysis of unmanned aerial vehicle (UAV) images. PloS one 2013;8(10):e77151.

Peña JM, Torres-Sánchez J, Serrano-Pérez A, Castro AI de, López-Granados F. Quantifying efficacy and limits of unmanned aerial vehicle (UAV) technology for weed seedling detection as affected by sensor resolution. Sensors (Basel, Switzerland) 2015;15(3):560926.

Pérez-Ortiz M, Peña JM, Gutiérrez PA, Torres-Sánchez J, Hervás-Martínez C, LÓPEZGRANADOS F. A semi-supervised system for weed mapping in sunflower crops using unmanned aerial vehicles and a crop row detection method. APPLIED SOFT COMPUTING 2015;37:533-44.

Pleasants JM, Oberhauser KS. Milkweed loss in agricultural fields because of herbicide use: Effect on the monarch butterfly population. INSECT CONSERVATION AND DIVERSITY 2013;6(2):135-44.

Potgieter AB, George-Jaeggli B, Chapman SC, Laws K, Suárez Cadavid LA, Wixted J et al. Multi-Spectral Imaging from an Unmanned Aerial Vehicle Enables the Assessment of Seasonal Leaf Area Dynamics of Sorghum Breeding Lines. Frontiers in plant science 2017;8:1532.

Potts SG, Biesmeijer JC, Kremen C, Neumann P, Schweiger O, Kunin WE. Global pollinator declines: Trends, impacts and drivers. Trends in ecology \& evolution 2010;25(6):345-53.

Prezoto F, Maciel TT, Detoni M, Mayorquin AZ, Barbosa BC. Pest Control Potential of Social Wasps in Small Farms and Urban Gardens. Insects 2019;10(7):192.

Rader R, Bartomeus I, Garibaldi LA, Garratt MPD, Howlett BG, Winfree R et al. Non-bee insects are important contributors to global crop pollination. PROCEEDINGS OF THE NATIONAL ACADEMY OF SCIENCES OF THE UNITED STATES OF AMERICA 2016;113(1):146-51.

Rango A, Laliberte A, Steele C, Herrick JE, Bestelmeyer B, Schmugge T et al. Using Unmanned Aerial Vehicles for Rangelands: Current Applications and Future Potentials. Environmental Practice 2006;8(3):159-68. 
Rasmussen J, Nielsen J, Garcia-Ruiz F, Christensen S, Streibig JC, Lotz B. Potential uses of small unmanned aircraft systems (UAS) in weed research. Weed Res 2013;53(4):242-8.

Ratto F, Simmons BI, Spake R, Zamora-Gutierrez V, MacDonald MA, Merriman JC et al. Global importance of vertebrate pollinators for plant reproductive success: a meta-analysis. Front Ecol Environ 2018;16(2):82-90.

Redlich S, Martin EA, Steffan-Dewenter I. Landscape-level crop diversity benefits biological pest control. J Appl Ecol 2018;55(5):2419-28.

Reif MK, Theel HJ. Remote sensing for restoration ecology: Application for restoring degraded, damaged, transformed, or destroyed ecosystems. INTEGRATED ENVIRONMENTAL ASSESSMENT AND MANAGEMENT 2017;13(4):614-30.

Rew LJ, Cousens RD. Spatial distribution of weeds in arable crops: Are current sampling and analytical methods appropriate? Weed Res 2001;41(1):1-18.

Rey-Caramés C, Diago M, Martín M, Lobo A, Tardaguila J. Using RPAS Multi-Spectral Imagery to Characterise Vigour, Leaf Development, Yield Components and Berry Composition Variability within a Vineyard. Remote Sensing 2015;7(11):14458-81.

Ribeiro MC, Metzger JP, Martensen AC, Ponzoni FJ, Hirota MM. The Brazilian Atlantic Forest: How much is left, and how is the remaining forest distributed? Implications for conservation. Biological Conservation 2009;142(6):1141-53.

Rockström J, Steffen W, Noone K, Persson A, Chapin FS, Lambin EF et al. A safe operating space for humanity. Nature 2009;461(7263):472-5.

Roosjen PPJ, Brede B, Suomalainen JM, Bartholomeus HM, Kooistra L, Clevers JGPW. Improved estimation of leaf area index and leaf chlorophyll content of a potato crop using multi-angle spectral data - potential of unmanned aerial vehicle imagery. International Journal of Applied Earth Observation and Geoinformation 2018;66:14-26.

Rosa-Schleich J, Loos J, Mußhoff O, Tscharntke T. Ecological-economic trade-offs of Diversified Farming Systems-A review. Ecological Economics 2019;160:251-63.

Ruwaimana M, Satyanarayana B, Otero V, M Muslim A, Syafiq A M, Ibrahim S et al. The advantages of using drones over space-borne imagery in the mapping of mangrove forests. PloS one 2018;13(7):e0200288.

Saavoss M, Majsztrik J, Belayneh B, Lea-Cox J, Lichtenberg E. Yield, quality and profitability of sensor-controlled irrigation: A case study of snapdragon (Antirrhinum majus L.) production. Irrigation Science 2016;34(5):409-20. 
Samiappan S, Turnage G, Hathcock L, Casagrande L, Stinson P, Moorhead R. Using unmanned aerial vehicles for high-resolution remote sensing to map invasive Phragmites australis in coastal wetlands. International Journal of Remote Sensing 2016a;38(8-10):2199-217.

Samiappan S, Turnage G, Hathcock LA, Moorhead R. Mapping of invasive phragmites (common reed) in Gulf of Mexico coastal wetlands using multispectral imagery and small unmanned aerial systems. International Journal of Remote Sensing 2016b;38(8-10):286182.

Sanches GM, Duft DG, Kölln OT, Luciano ACdS, Castro SGQ de, Okuno FM et al. The potential for RGB images obtained using unmanned aerial vehicle to assess and predict yield in sugarcane fields. International Journal of Remote Sensing 2018;39(15-16):540214.

Savary S, Willocquet L, Pethybridge SJ, Esker P, McRoberts N, Nelson A. The global burden of pathogens and pests on major food crops. Nature Ecology \& Evolution 2019;3(3):430-9.

Schirrmann M, Giebel A, Gleiniger F, Pflanz M, Lentschke J, Dammer K-H. Monitoring agronomic parameters of winter wheat crops with low-cost UAV imagery. Remote Sensing 2016;8(9).

Schmidtlein S, Fassnacht FE. The spectral variability hypothesis does not hold across landscapes. Remote Sensing of Environment 2017;192:114-25.

Schütte G, Eckerstorfer M, Rastelli V, Reichenbecher W, Restrepo-Vassalli S, Ruohonen-Lehto $\mathrm{M}$ et al. Herbicide resistance and biodiversity: agronomic and environmental aspects of genetically modified herbicide-resistant plants. Environmental Sciences Europe 2017;29(1):5.

Shields EJ, Dauer JT, VanGessel MJ, Neumann G. Horseweed (Conyza canadensis) seed collected in the planetary boundary layer. Weed Science 2006;54(6):1063-7.

Shin, P., Sankey, T., Moore, M.M., Thode, A.E., 2018. Evaluating unmanned aerial vehicle images for estimating forest canopy fuels in a ponderosa pine stand. Remote Sens.10 (8), 1266.

Sigernes F, Syrjäsuo M, Storvold R, Fortuna J, Grøtte ME, Johansen TA. Do it yourself hyperspectral imager for handheld to airborne operations. OPTICS EXPRESS 2018;26(5):6021-35.

Silva B, Lehnert L, Roos K, Fries A, Rollenbeck R, Beck E et al. Mapping Two Competing Grassland Species from a Low-Altitude Helium Balloon. IEEE J. Sel. Top. Appl. Earth Observations Remote Sensing 2014;7(7):3038-49. 
Singh TVK, Satyanarayana J. Insect outbreaks and their management. In: Integrated pest management: innovation-development process: SPRINGER; 2009. p. 331-350.

Smith EA, Fuchs M, Shields EJ, Nault BA. Long-Distance Dispersal Potential for Onion Thrips (Thysanoptera: Thripidae) and Iris yellow spot virus (Bunyaviridae: Tospovirus) in an Onion Ecosystem. Environmental entomology 2015;44(4):921-30.

Sofonia J, Shendryk Y, Phinn S, Roelfsema C, Kendoul F, Skocaj D. Monitoring sugarcane growth response to varying nitrogen application rates: A comparison of UAV SLAM LiDAR and photogrammetry. International Journal of Applied Earth Observation and Geoinformation 2019;82.

Southon RJ, Fernandes OA, Nascimento FS, Sumner S. Social wasps are effective biocontrol agents of key lepidopteran crop pests. Proceedings. Biological sciences 2019;286(1914):20191676.

Steffen W, Richardson K, Rockstrom J, Cornell SE, Fetzer I, Bennett EM et al. Planetary boundaries: Guiding human development on a changing planet. SCIENCE $2015 ; 347(6223)$.

Storck V, Karpouzas DG, Martin-Laurent F. Towards a better pesticide policy for the European Union. SCIENCE OF THE TOTAL ENVIRONMENT 2017;575:1027-33.

Storkey J. A functional group approach to the management of UK arable weeds to support biological diversity. Weed Res 2006;46(6):513-22.

Storkey J, Meyer S, Still KS, Leuschner C. The impact of agricultural intensification and landuse change on the European arable flora. Proceedings. Biological sciences 2012;279(1732):1421-9.

Strong CJ, Burnside NG, Llewellyn D. The potential of small-Unmanned Aircraft Systems for the rapid detection of threatened unimproved grassland communities using an Enhanced Normalized Difference Vegetation Index. PloS one 2017;12(10):e0186193.

Sugiura R, Noguchi N, Ishii K. Correction of Low-altitude Thermal Images applied to estimating Soil Water Status. Biosystems Engineering 2007;96(3):301-13.

Sugiura R, Tsuda S, Tamiya S, Itoh A, Nishiwaki K, Murakami N et al. Field phenotyping system for the assessment of potato late blight resistance using RGB imagery from an unmanned aerial vehicle. Biosystems Engineering 2016;148:1-10.

Surový, P., Almeida Ribeiro, N., Panagiotidis, D., 2018. Estimation of positions and heights from UAV-sensed imagery in tree plantations in agrosilvopastoral systems. Int. J. Remote Sens. 39 (14), 4786-4800. 
Sutter L, Albrecht M, Jeanneret P, Diekötter T. Landscape greening and local creation of wildflower strips and hedgerows promote multiple ecosystem services. J Appl Ecol 2018;55(2):612-20.

Tang, L., Shao, G., 2015. Drone remote sensing for forestry research and practices. J. For. Res. 26 (4), 791-797.

Tetila EC, Machado BB, de Souza Belete, Nicolas Alessandro, Guimaraes DA, Pistori H. Identification of Soybean Foliar Diseases Using Unmanned Aerial Vehicle Images. IEEE GEOSCIENCE AND REMOTE SENSING LETTERS 2017;14(12):2190-4.

Tilman D, Cassman KG, Matson PA, Naylor R, Polasky S. Agricultural sustainability and intensive production practices. Nature 2002;418(6898):671-7.

Tomé HVV, Barbosa WF, Corrêa AS, Gontijo LM, Martins GF, Guedes RNC. Reduced-risk insecticides in Neotropical stingless bee species: impact on survival and activity. Ann Appl Biol 2015;167(2):186-96.

Torres-Sánchez J, López-Granados F, Castro AI de, Peña-Barragán JM. Configuration and specifications of an Unmanned Aerial Vehicle (UAV) for early site specific weed management. PloS one 2013;8(3):e58210.

Trejo-Salazar R-E, Eguiarte LE, Suro-Piñera D, Medellin RA. Save Our Bats, Save Our Tequila: Industry and Science Join Forces to Help Bats and Agaves. Natural Areas Journal 2016;36(4):523-30.

Tscharntke T, Bommarco R, Clough Y, Crist TO, Kleijn D, Rand TA et al. Conservation biological control and enemy diversity on a landscape scale. Biological Control 2007;43(3):294-309.

Tscharntke T, Klein AM, Kruess A, Steffan-Dewenter I, Thies C. Landscape perspectives on agricultural intensification and biodiversity â $\square$ “ ecosystem service management. Ecology letters 2005;8(8):857-74.

Tscharntke T, Tylianakis JM, Rand TA, Didham RK, Fahrig L, Batáry P et al. Landscape moderation of biodiversity patterns and processes - eight hypotheses. Biological reviews of the Cambridge Philosophical Society 2012;87(3):661-85.

Tschumi M, Albrecht M, Entling MH, Jacot K. High effectiveness of tailored flower strips in reducing pests and crop plant damage. Proceedings. Biological sciences 2015;282(1814).

Vandermeer J, Perfecto I. Ecological complexity and agroecosystems: Seven themes from theory. Agroecology and Sustainable Food Systems 2017;41(7):697-722. 
Vanegas F, Bratanov D, Powell K, Weiss J, Gonzalez F. A Novel Methodology for Improving Plant Pest Surveillance in Vineyards and Crops Using UAV-Based Hyperspectral and Spatial Data. Sensors (Basel, Switzerland) 2018;18(1).

Wachendorf M, Fricke T, Möckel T. Remote sensing as a tool to assess botanical composition, structure, quantity and quality of temperate grasslands. GRASS AND FORAGE SCIENCE 2018;73(1):1-14.

Wallace, L., Lucieer, A., Malenovský, Z., Turner, D., Vopenka, P., 2016. Assessment of forest structure using two UAV techniques: A comparison of airborne laser scanning and structure from motion (SfM) point clouds. Forests 7 (3), 62.

Walter A, Finger R, Huber R, Buchmann N. Opinion: Smart farming is key to developing sustainable agriculture. PROCEEDINGS OF THE NATIONAL ACADEMY OF SCIENCES OF THE UNITED STATES OF AMERICA 2017;114(24):6148-50.

Walton NJ, Isaacs R. Influence of native flowering plant strips on natural enemies and herbivores in adjacent blueberry fields. Environmental entomology 2011;40(3):697-705.

Wang R, Zhang S, Pu L, Yang J, Yang C, Chen J et al. Gully Erosion Mapping and Monitoring at Multiple Scales Based on Multi-Source Remote Sensing Data of the Sancha River Catchment, Northeast China. IJGI 2016;5(11):200.

Wang W, Wang X, Wang L, Lu Y, Li Y, Sun X. Soil moisture estimation for spring wheat in a semiarid area based on low-altitude remote-sensing data collected by small-sized unmanned aerial vehicles. JOURNAL OF APPLIED REMOTE SENSING 2018;12(2).

Ward S, Hensler J, Alsalam B, Gonzalez LF. Autonomous UAVs wildlife detection using thermal imaging, predictive navigation and computer vision 2016.

Watts AC, Perry JH, Smith SE, Burgess MA, Wilkinson BE, Szantoi Z et al. Small Unmanned Aircraft Systems for Low-Altitude Aerial Surveys. Journal of Wildlife Management 2010;74(7):1614-9.

Weissensteiner MH, Poelstra JW, Wolf JBW. Low-budget ready-to-fly unmanned aerial vehicles: An effective tool for evaluating the nesting status of canopy-breeding bird species. J Avian Biol 2015;46(4):425-30.

Westphal C, Vidal S, Horgan FG, Gurr GM, Escalada M, van Chien H et al. Promoting multiple ecosystem services with flower strips and participatory approaches in rice production landscapes. Basic and Applied Ecology 2015;16(8):681-9.

Wezel A, Bellon S, Doré T, Francis C, Vallod D, David C. Agroecology as a science, a movement and a practice. A review. Agron. Sustain. Dev. 2009;29(4):503-15. 
Whitehead K, Hugenholtz CH. Remote sensing of the environment with small unmanned aircraft systems (UASs), part 1: A review of progress and challenges. Journal of Unmanned Vehicle Systems 2014;2(3):69-85.

Wich SA, Koh LP. Conservation drones: Mapping and monitoring biodiversity. 1st ed. Oxford, New York, NY: Oxford University Press; 2018.

Wilson C, Tisdell C. Why farmers continue to use pesticides despite environmental, health and sustainability costs. Ecological Economics 2001;39(3):449-62.

Woodcock BA, Bullock JM, Shore RF, Heard MS, Pereira MG, Redhead J et al. Country-specific effects of neonicotinoid pesticides on honey bees and wild bees. SCIENCE 2017;356(6345):1393-5.

Wu J, Wang D, Bauer ME. Assessing broadband vegetation indices and QuickBird data in estimating leaf area index of corn and potato canopies. Field Crops Research 2007;102(1):33-42.

WWF. Living Planet Report: Risk and resilience in a new era. WWF International, Gland, Switzerland; 2016.

Xavier S, Coffin A, Olson D, Schmidt J. Remotely Estimating Beneficial Arthropod Populations: Implications of a Low-Cost Small Unmanned Aerial System. Remote Sensing 2018;10(9):1485.

Yao X, Wang N, Liu Y, Cheng T, Tian Y, Chen Q et al. Estimation of Wheat LAI at Middle to High Levels Using Unmanned Aerial Vehicle Narrowband Multispectral Imagery. Remote Sensing 2017;9(12):1304.

Yin X, Jaja N, McClure MA, Hayes RM. Comparison of models in assessing relationship of corn yield with plant height measured during early-to mid-season. Journal of Agricultural Science 2011;3(3):14.

Zahawi RA, Dandois JP, Holl KD, Nadwodny D, Reid JL, Ellis EC. Using lightweight unmanned aerial vehicles to monitor tropical forest recovery. Biological Conservation 2015;186:287-95.

Zarco-Tejada, P.J., Guillén-Climent, M.L., Hernández-Clemente, R., Catalina, A., González, M.R., Martín, P., 2013. Estimating leaf carotenoid content in vineyards using high resolution hyperspectral imagery acquired from an unmanned aerial vehicle (UAV). Agric. For. Meteorol. 171-172, 281-294.

Zarco-Tejada, P.J., Diaz-Varela, R., Angileri, V., Loudjani, P., 2014. Tree height quantification using very high resolution imagery acquired from an unmanned aerial vehicle (UAV) and automatic 3D photo-reconstruction methods. Eur. J. Agron. 55, 89-99. 
Zhang C, Kovacs JM. The application of small unmanned aerial systems for precision agriculture: A review. Precision Agric 2012;13(6):693-712.

Zhao G, Miao Y, Wang H, Su M, Fan M, Zhang F et al. A preliminary precision rice management system for increasing both grain yield and nitrogen use efficiency. Field Crops Research 2013;154:23-30.

Zhao H, Peng S, Wu J, Xiao H, Chen B. Allelopathic potential of native plants on invasive plant Mikania micrantha HBK in South China. ALLELOPATHY JOURNAL 2008;22(1):18995.

Zhou X, Zheng HB, Xu XQ, He JY, Ge XK, Yao X et al. Predicting grain yield in rice using multi-temporal vegetation indices from UAV-based multispectral and digital imagery. ISPRS Journal of Photogrammetry and Remote Sensing 2017;130:246-55. 


\section{Supplementary material}

From 1995 to 2018 UAVs publications showed a growth rate of 30.64\% resulting in a doubling of output in less than 2.3 years, therefore nearly tripling the mean publication growth rate in science (Larsen and Ins, 2010; Bornmann and Mutz, 2015).

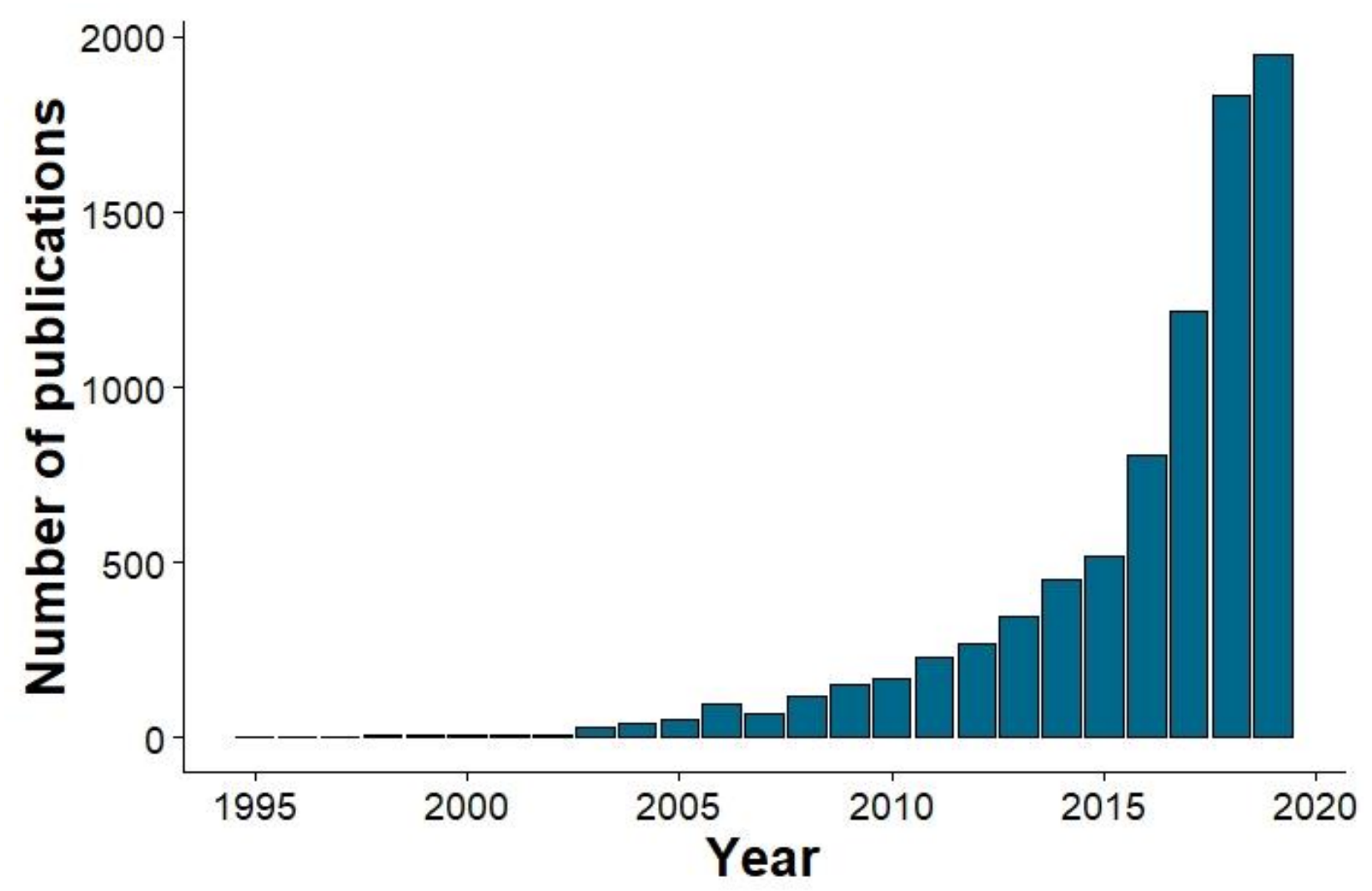

Figure S1. Total number of publications per year in Web of Science core collection under the topic "unmanned aerial" from 1995 to 2019 as of October $10^{\text {th }} 2019$.

\section{References}

Bornmann, L., Mutz, R., 2015. Growth rates of modern science. A bibliometric analysis based on the number of publications and cited references. J Assn Inf Sci Tec 66, 2215-2222.

Larsen, P.O., Ins, M. von, 2010. The rate of growth in scientific publication and the decline in coverage provided by Science Citation Index. Scientometrics 84, 575-603. 
Table S1. Technical details of all studies using UAVs cited throughout the review sections.

\begin{tabular}{|c|c|c|c|c|c|c|c|c|c|c|c|c|}
\hline $\begin{array}{c}\text { UAV } \\
\text { application }\end{array}$ & Authors & $\begin{array}{c}\text { Study } \\
\text { objective }\end{array}$ & Sensor & Platform & $\begin{array}{c}\text { Flight } \\
\text { height } \\
\text { (m) }\end{array}$ & $\begin{array}{l}\text { Indices } \\
\text { used }\end{array}$ & $\begin{array}{l}\text { Processing } \\
\text { software }\end{array}$ & Built products & $\begin{array}{l}\text { Resolution }(\mathrm{cm}) \text { : } \\
\text { GSD or cell size }\end{array}$ & Accuracy & $\begin{array}{l}\text { Other data } \\
\text { sources used }\end{array}$ & Comments \\
\hline \multirow[t]{4}{*}{$\begin{array}{l}3.1 \\
\text { Biodiversity } \\
\text { conservation }\end{array}$} & $\begin{array}{l}\text { Ahmed et } \\
\text { al., } 2017\end{array}$ & $\begin{array}{l}\text { Vegetation } \\
\text { classification }\end{array}$ & $\begin{array}{c}\text { Sony DSC-WX220 } \\
\text { (RGB) and Parrot } \\
\text { Sequoia } \\
\text { (multispectral) }\end{array}$ & $\begin{array}{l}\text { SenseFly eBee } \\
\text { (fixed-wing) }\end{array}$ & 120 & NDVI & ENVI & $\begin{array}{l}\text { RGB: Orthomosaics, } \\
\text { point clouds and } \\
\text { DSM } \\
\text { Multispectral: } \\
\text { Colour-balanced } \\
\text { orthomosaics, non- } \\
\text { balanced 'raw' } \\
\text { reflectance and } \\
\text { NDVI maps }\end{array}$ & $\begin{array}{c}\text { RGB: } 2.6-3.5 \\
\text { Multispectral: } 5.7\end{array}$ & $\begin{array}{l}\text { Overall accuracy } \\
78-95 \% \\
\text { depending on } \\
\text { sensor, resolution } \\
\text { and classification } \\
\text { detail. }\end{array}$ & $\begin{array}{l}\text { Reflectance } \\
\text { data calibrated } \\
\text { with spectral } \\
\text { reflectance } \\
\text { measurements } \\
\text { obtained with } \\
\text { an ASD Field } \\
\text { Spectrometer }\end{array}$ & - \\
\hline & $\begin{array}{l}\text { Cruzan et } \\
\text { al., } 2016\end{array}$ & $\begin{array}{l}\text { Plant species } \\
\text { and vegetation } \\
\text { types } \\
\text { distributions } \\
\end{array}$ & RGB & $\begin{array}{c}\text { DJI Phantom } 2 \\
\text { Vision+ } \\
\text { (quadcopter) }\end{array}$ & 40 & None & Agisoft PhotoScan & $\begin{array}{c}\text { Orthomosaic and } \\
\text { DSM }\end{array}$ & $\sim 2$ & Not reported & No & $\begin{array}{l}\text { R scripts used for } \\
\text { automated } \\
\text { habitat } \\
\text { delineation }\end{array}$ \\
\hline & $\begin{array}{l}\text { Getzin et } \\
\text { al., } 2012\end{array}$ & $\begin{array}{c}\text { Forest } \\
\text { biodiversity } \\
\text { assessment }\end{array}$ & RGB & Fixed-wing & $\sim 250$ & $\mathrm{GSCl}$ & ArcGIS & Shapefiles & 7 & $\begin{array}{c}\mathrm{R} 2=0.47-0.74, \mathrm{P} \\
\text { values }<0.001\end{array}$ & No & $\begin{array}{c}\text { Gap polygons } \\
\text { from orthophotos } \\
\text { manually } \\
\text { segmented to } \\
\text { create shapefiles. }\end{array}$ \\
\hline & $\begin{array}{l}\text { Habel et al., } \\
2016\end{array}$ & $\begin{array}{c}\text { Butterflies } \\
\text { micro-habitat } \\
\text { mapping and } \\
\text { characterization }\end{array}$ & $\begin{array}{c}\text { GoPro HERO } 4 \\
\text { Black (RGB) }\end{array}$ & $\begin{array}{l}\text { DJI Phantom } 2 \\
\text { (quadcopter) }\end{array}$ & 40 & None & $\begin{array}{l}\text { AgiSoft Photoscan } \\
\text { Professional }\end{array}$ & $\begin{array}{c}\text { Georeferenced } \\
\text { orthomosaic and } \\
\text { HSM }\end{array}$ & 2 & $\begin{array}{c}\text { HSM feeding } \\
\text { plants: } \\
\begin{aligned} A U C= & 0.72, \text { COR } \\
& =0.39 \\
\text { HSM for larvae: } & \\
\text { AUC }= & 0.72, \text { COR }= \\
& 0.22\end{aligned}\end{array}$ & $\begin{array}{l}\text { Verification in } \\
\text { the field }\end{array}$ & $\begin{array}{l}\text { Input variables } \\
\text { for HSMs were } \\
\text { aerial pictures } \\
\text { decomposed into } \\
\text { RGB channels }\end{array}$ \\
\hline \multirow[t]{4}{*}{$\begin{array}{l}\text { a. Plant } \\
\text { diversity }\end{array}$} & $\begin{array}{l}\text { Knoth et } \\
\text { al., } 2013\end{array}$ & $\begin{array}{l}\text { Restoration } \\
\text { monitoring }\end{array}$ & $\begin{array}{c}\text { Modified Canon } \\
\text { Ixus } 400 \text { (captures } \\
\text { NIR) and modified } \\
\text { Panasonic } \\
\text { Lumix LX-3 } \\
\text { (captures VIS and } \\
\text { NIR) } \\
\end{array}$ & $\begin{array}{l}\text { Mikrokopter } \\
\text { and } \\
\text { Microdrone } \\
\text { MD4-1000 } \\
\text { (quadcopters) }\end{array}$ & $15-100$ & $\begin{array}{l}\mathrm{NIR} / \mathrm{blue} \\
\text { ratio to } \\
\text { generate } \\
\text { NIR- } \\
\text { albedo } \\
\text { variation }\end{array}$ & $\begin{array}{l}\text { ERDAS Imagine } \\
\text { including the Leica } \\
\text { Photogrammetry } \\
\text { Suite and } \\
\text { eCognition } \\
\text { Developer }\end{array}$ & CIR orthomosaic & 3 and $<1.5$ & $\begin{array}{c}\text { Overall accuracy } \\
84-95 \%\end{array}$ & No & - \\
\hline & $\begin{array}{l}\text { Lu \& He, } \\
2017\end{array}$ & $\begin{array}{l}\text { Grassland } \\
\text { species } \\
\text { classification }\end{array}$ & $\begin{array}{c}\text { Modified Canon } \\
\text { PowerShot ELPH } \\
\text { 11OHS (captures } \\
\text { VIS and NIR) }\end{array}$ & $\begin{array}{l}\text { Tarot T15 } \\
\text { (octocopter) }\end{array}$ & 70 & $\begin{array}{c}\text { Blue NDVI } \\
\text { and Green } \\
\text { NDVI }\end{array}$ & $\begin{array}{l}\text { Agisoft Photoscan, } \\
\text { ArcGIS and ENVI }\end{array}$ & Orthomosaics & 5 & $R^{2}=0.6-0.95$ & $\begin{array}{c}\text { Canopy } \\
\text { reflectance data } \\
\text { collected using } \\
\text { a } \\
\text { spectroradiome } \\
\text { ter. }\end{array}$ & - \\
\hline & $\begin{array}{l}\text { Michez et } \\
\text { al., } 2016\end{array}$ & $\begin{array}{l}\text { Riparian forest } \\
\text { species } \\
\text { classification } \\
\text { and health } \\
\text { condition }\end{array}$ & $\begin{array}{l}\text { Ricoh GR3 camera } \\
\text { (RGB) }\end{array}$ & $\begin{array}{l}\text { Gatewing X100 } \\
\text { (fixed-wing) }\end{array}$ & $114-404$ & Multiple & $\begin{array}{l}\text { Agisoft Photoscan } \\
\text { Professional }\end{array}$ & Orthomosaic & $10-25$ & $\begin{array}{c}\text { Species } \\
\text { clasification: } 48.5- \\
84.1 \% \text { depending } \\
\text { on site and scale } \\
\text { of analysis. } \\
\text { Health condition: } \\
81 \pm 10.8-90.6 \pm 0.7\end{array}$ & $\begin{array}{l}\text { LiDAR digital } \\
\text { terrain model } \\
\text { (DTM) }\end{array}$ & - \\
\hline & $\begin{array}{l}\text { Silva et al., } \\
2014\end{array}$ & $\begin{array}{c}\text { Grassland } \\
\text { species mapping }\end{array}$ & $\begin{array}{c}\text { Canon Ixus-90 (RGB } \\
\text { ) and modified } \\
\text { RG715 (captures } \\
\text { NIR) }\end{array}$ & $\begin{array}{l}\text { Helium } \\
\text { balloon }\end{array}$ & 35 & $\begin{array}{c}\text { Foliage } \\
\text { projective } \\
\text { cover and } \\
\text { LAl }\end{array}$ & $\begin{array}{l}\text { Open source: } \\
\text { "Bundler", } \\
\text { "GRASS", "SAGA" } \\
\text { and "gbm" R- } \\
\text { package }\end{array}$ & DSM & 1 & $\begin{array}{l}\text { AUC 0.81-0.99. } \\
\text { AUC=0.88 in } \\
\text { average }\end{array}$ & $\begin{array}{l}\text { Field } \\
\text { Spectroscopy } \\
\text { with the field } \\
\text { spectrometer } \\
\text { (Handyspec-14) }\end{array}$ & $\begin{array}{l}\text { Also used } R \text { and } \\
\text { Python languages }\end{array}$ \\
\hline
\end{tabular}




\begin{tabular}{|c|c|c|c|c|c|c|c|c|c|c|c|c|}
\hline & $\begin{array}{l}\text { Zahawi et } \\
\text { al., } 2015\end{array}$ & $\begin{array}{l}\text { Monitor tropical } \\
\text { forest recovery }\end{array}$ & $\begin{array}{c}\text { Canon ELPH } 520 \\
\text { HS (RGB) }\end{array}$ & $\begin{array}{l}\text { HiSystems } \\
\text { Mikrokopter } \\
\text { (hexacopter) }\end{array}$ & $\begin{array}{l}\text { 30-40 m } \\
\text { above } \\
\text { canopy }\end{array}$ & None & $\begin{array}{l}\text { Agisoft Photoscan } \\
\text { and ArcGIS }\end{array}$ & $\begin{array}{l}\text { Point clouds, DTM } \\
\text { and CHM. }\end{array}$ & 30 & $R^{2}=0.53-0.85$ & $\begin{array}{l}\text { Compared to } \\
\text { LiDAR } \\
\text { measurements }\end{array}$ & $\begin{array}{l}\text { Also used } R \text { and } \\
\text { Python languages }\end{array}$ \\
\hline \multirow{8}{*}{$\begin{array}{l}\text { b. Animal } \\
\text { diversity }\end{array}$} & $\begin{array}{c}\text { Chrétien et } \\
\text { al., } 2016\end{array}$ & Wildlife surveys & $\begin{array}{l}\text { FLIR Tau640 sensor } \\
\text { (thermal) and } \\
\text { D7000 sensor } \\
\text { (RGB) }\end{array}$ & $\begin{array}{l}\text { ING Robotic } \\
\text { Responder } \\
\text { (helicopter) }\end{array}$ & 60 & None & Not specified & Orthomosaics & $\begin{array}{c}\text { RGB: } 0.8 \\
\text { Thermal: } 5.4\end{array}$ & $\begin{array}{l}100 \% \text { detection } \\
\text { rate open land } \\
\text { deer. } 52 \% \\
\text { detection rate } \\
\text { overall }\end{array}$ & No & - \\
\hline & $\begin{array}{c}\text { Cukor et al., } \\
2019\end{array}$ & $\begin{array}{c}\text { Reduce } \\
\text { mortality of roe } \\
\text { deer fawns }\end{array}$ & $\begin{array}{l}\text { LWIR Workswell } \\
\text { WIRIS 2nd } \\
\text { generation } \\
\text { (thermal) }\end{array}$ & $\begin{array}{l}\text { GD HX-1100F } \\
\text { ZODIAC } \\
\text { (hexacopter) }\end{array}$ & 40 & None & $\begin{array}{c}\text { DJI GO application } \\
\text { and } \\
\text { WorkswellCorePla } \\
\text { yer }\end{array}$ & Thermogram & $\sim 10$ & $\begin{array}{l}100 \% \text { search } \\
\text { success rate }\end{array}$ & No & - \\
\hline & $\begin{array}{c}\text { Gonzalez et } \\
\text { al., } 2016\end{array}$ & $\begin{array}{c}\text { Wildlife } \\
\text { monitoring }\end{array}$ & $\begin{array}{l}\text { FLIR Tau 2-640 } \\
\text { (thermal) and } \\
\text { Mobius (RGB) }\end{array}$ & $\begin{array}{l}\text { S800 EVO } \\
\text { (hexacopter) }\end{array}$ & $\begin{array}{c}20,30 \\
60 \text { and } \\
80\end{array}$ & None & Not specified & $\begin{array}{c}\text { Thermal and RGB } \\
\text { images }\end{array}$ & $\begin{array}{c}\text { RGB: } 17-\sim 70 \\
\text { Thermal: } \sim 5-\sim 20\end{array}$ & $\begin{array}{c}100 \% \text { accuracy at } \\
<60 \mathrm{~m} \text { height }\end{array}$ & No & $\begin{array}{c}\text { Used two } \\
\text { algorithms to } \\
\text { automatically } \\
\text { classify and count } \\
\text { wildlife (Python) }\end{array}$ \\
\hline & $\begin{array}{c}\text { Hodgson et } \\
\text { al., } 2016\end{array}$ & $\begin{array}{l}\text { Bird colony } \\
\text { estimation }\end{array}$ & $\begin{array}{c}\text { Canon EOS M } \\
\text { mirrorless camera } \\
(\mathrm{RGB})\end{array}$ & $\begin{array}{c}\text { X8 3D Robotics } \\
\text { (octocopter) } \\
\text { and FX79 } \\
\text { airframe } \\
\text { conservation } \\
\text { drone (fixed- } \\
\text { wing) } \\
\end{array}$ & $\begin{array}{c}75 \text { and } \\
120\end{array}$ & None & Adobe Photoshop & Composite & 1.5 & $\begin{array}{l}\text { UAV counts ten } \\
\text { times more } \\
\text { accurate than } \\
\text { ground counts }\end{array}$ & No & - \\
\hline & $\begin{array}{l}\text { Israel \& } \\
\text { Reinhard, } \\
2017\end{array}$ & $\begin{array}{l}\text { Reduce } \\
\text { mortality of } \\
\text { lapwings }\end{array}$ & $\begin{array}{c}\text { Tau } 640 \text { infrared } \\
\text { (thermal) and } \\
\text { GoPro } 3 \text { Black Plus } \\
\text { (RGB) }\end{array}$ & $\begin{array}{l}\text { Falcon } 8 \text { from } \\
\text { Ascending } \\
\text { Technologies } \\
\text { (octocopter) }\end{array}$ & 40 & None & Not specified & Thermogram & 3.18 & $93 \%$ & No & $\begin{array}{l}\text { MbOpt algorithm } \\
\text { to improve } \\
\text { detectability }\end{array}$ \\
\hline & $\begin{array}{c}\text { Mulero- } \\
\text { Pazmany \& } \\
\text { Negro- } \\
\text { Balmaseda, } \\
2011 \\
\end{array}$ & $\begin{array}{l}\text { Reduce } \\
\text { mortality of } \\
\text { Montagu's } \\
\text { Harriers }\end{array}$ & $\begin{array}{l}\text { Panasonic Lumix } \\
\text { LX3 (RGB) }\end{array}$ & Fixed-wing & 70 & None & Arc GIS & $\begin{array}{c}\text { Georeferenced } \\
\text { aerial photographs }\end{array}$ & $\sim 5$ & $\begin{array}{l}64 \% \text { search } \\
\text { success rate }\end{array}$ & No & - \\
\hline & $\begin{array}{l}\text { Ward et al., } \\
2016\end{array}$ & $\begin{array}{l}\text { Wildlife } \\
\text { detection and } \\
\text { monitoring }\end{array}$ & $\begin{array}{l}\text { FLIR Lepton } \\
\text { (thermal) }\end{array}$ & $\begin{array}{c}\text { 3DR IRIS } \\
\text { (quadcopter) }\end{array}$ & 10 & None & Not specified & Thermogram & Not specified & - & No & $\begin{array}{l}\text { Open-source } \\
\text { detection } \\
\text { algorithms } \\
\text { (written in } \\
\text { Python) }\end{array}$ \\
\hline & $\begin{array}{c}\text { Weissenstei } \\
\text { ner et al., } \\
2015\end{array}$ & $\begin{array}{l}\text { Nesting status } \\
\text { evaluation of } \\
\text { canopy- } \\
\text { breeding birds }\end{array}$ & RGB & $\begin{array}{c}\text { DJl Phantom 2 } \\
\text { Vision } \\
\text { (quadcopter) }\end{array}$ & $10-30$ & None & - & - & $<1$ & $\begin{array}{l}\text { Nestling number } \\
\text { accuracy } 75 \% \text {. } \\
\text { UAV nesting } \\
\text { status assessment } \\
7.4 \text { times faster } \\
\text { than climbing ( } \\
P<0.005 \text { ) }\end{array}$ & No & - \\
\hline
\end{tabular}




\begin{tabular}{|c|c|c|c|c|c|c|c|c|c|c|c|c|}
\hline $\begin{array}{l}3.2 \\
\text { Agricultural } \\
\text { land } \\
\text { monitoring }\end{array}$ & $\begin{array}{l}\text { Bareth et } \\
\text { al. } 2016\end{array}$ & $\begin{array}{c}\text { Barley } \\
\text { monitoring }\end{array}$ & $\begin{array}{l}\text { Panasonic Lumix } \\
\text { GX1(RGB) }\end{array}$ & $\begin{array}{l}\text { HiSystems } \\
\text { MikroKopter } \\
\text { MKOkto } \\
\text { (octocopter) }\end{array}$ & 50 & None & $\begin{array}{l}\text { Agisoft PhotoScan } \\
\text { Professional }\end{array}$ & $\begin{array}{l}\text { Georeferenced } \\
\text { CSM }\end{array}$ & 0.9 & $R^{2}=0.91$ & $\begin{array}{l}\text { Compared to } \\
\text { terrestrial laser } \\
\text { scanning }\end{array}$ & - \\
\hline \multirow{8}{*}{$\begin{array}{l}\text { a. Plant } \\
\text { height } \\
\text { and biomass }\end{array}$} & $\begin{array}{l}\text { Bendig et } \\
\text { al., } 2014\end{array}$ & $\begin{array}{l}\text { Plant height } \\
\text { estimation }\end{array}$ & $\begin{array}{l}\text { Panasonic Lumix } \\
\text { GX1(RGB) }\end{array}$ & $\begin{array}{l}\text { HiSystems } \\
\text { MikroKopter } \\
\text { MKOkto } \\
\text { (octocopter) }\end{array}$ & 50 & None & $\begin{array}{l}\text { Agisoft PhotoScan } \\
\text { Professional }\end{array}$ & $\begin{array}{l}\text { Georeferenced } \\
\text { CSM }\end{array}$ & 1 & $R^{2}=0.71-0.92$ & No & - \\
\hline & $\begin{array}{l}\text { Grüner et } \\
\text { al., } 2019\end{array}$ & $\begin{array}{l}\text { Grassland } \\
\text { biomass } \\
\text { prediction }\end{array}$ & DJI FC300S (RGB) & $\begin{array}{l}\text { DJI Phantom } 3 \\
\text { Advanced } \\
\text { (quadcopter) }\end{array}$ & 20 & None & $\begin{array}{l}\text { Agisoft PhotoScan } \\
\text { Professional }\end{array}$ & DSM & $0.7-0.8$ & $\mathrm{R}^{2}=0.58-0.81$ & No & $\begin{array}{l}\text { Compared to } \\
\text { destructive } \\
\text { biomass sampling } \\
\text { and ruler height } \\
\text { measurements }\end{array}$ \\
\hline & $\begin{array}{l}\text { Guerra- } \\
\text { Hernández } \\
\text { et al., } 2017\end{array}$ & $\begin{array}{l}\text { Tree growth } \\
\text { estimation }\end{array}$ & $\begin{array}{l}\text { Canon Powershot } \\
\text { S110 (RGB) }\end{array}$ & $\begin{array}{l}\text { SenseFly eBee } \\
\text { (fixed-wing) }\end{array}$ & 170 & None & Pix4D & $\begin{array}{c}\text { Orthomosaics and } \\
\text { DSMs }\end{array}$ & 6 & $\begin{array}{c}\mathrm{R}^{2}=0.96 \\
\text { Detection rate } \\
100 \%\end{array}$ & No & - \\
\hline & $\begin{array}{l}\text { Kachamba } \\
\text { et al., } 2017\end{array}$ & $\begin{array}{l}\text { Biomass } \\
\text { estimates in dry } \\
\text { tropical forests }\end{array}$ & $\begin{array}{c}\text { Canon IXUS127 HS } \\
\text { (RGB) }\end{array}$ & $\begin{array}{l}\text { SenseFly eBee } \\
\text { (fixed-wing) }\end{array}$ & 325 & None & $\begin{array}{l}\text { Agisoft Photoscan } \\
\text { Professional }\end{array}$ & $\begin{array}{l}\text { Normalized point } \\
\text { cloud to generate } \\
\text { canopy height } \\
\text { variables }\end{array}$ & $\sim 20$ & $R^{2}=0.31-0.64$ & No & - \\
\hline & $\begin{array}{l}\text { Li et al., } \\
2016\end{array}$ & $\begin{array}{l}\text { Maize canopy } \\
\text { height and } \\
\text { aboveground } \\
\text { biomass } \\
\text { estimation }\end{array}$ & SONYA6000 (RGB) & $\begin{array}{l}\text { Not specified } \\
\text { multiple-rotor } \\
\text { system }\end{array}$ & 150 & $\begin{array}{c}7 \\
\text { greenness } \\
\text { Vls }\end{array}$ & $\begin{array}{l}\text { Smart3DCapture } \\
\text { to generate point } \\
\text { clouds }\end{array}$ & $\begin{array}{c}\text { Orthorectified } \\
\text { image and DSM }\end{array}$ & 2 & $\begin{array}{c}\mathrm{R}^{2}=0.88 \text { (multiple } \\
\text { stepwise linear } \\
\text { regressino } \\
\text { model); } \mathrm{R}^{2}=0.78 \\
\text { (random forest } \\
\text { regression) }\end{array}$ & No & - \\
\hline & $\begin{array}{l}\text { Shin et al., } \\
2018\end{array}$ & $\begin{array}{l}\text { Forest canopy } \\
\text { fuels estimation }\end{array}$ & multispectral & $\begin{array}{l}\text { SenseFly eBee } \\
\text { (fixed-wing) }\end{array}$ & 120 & NDVI & $\begin{array}{l}\text { Pix4D, ENVI and } \\
\text { CloudCompare }\end{array}$ & Orthomosaics & 15 & $R^{2}=0.72$ & No & - \\
\hline & $\begin{array}{l}\text { Surový et } \\
\text { al., } 2018\end{array}$ & $\begin{array}{l}\text { Tree position } \\
\text { and height } \\
\text { estimation }\end{array}$ & $\begin{array}{l}\text { Samsung K-Zoom } \\
\text { (RGB) }\end{array}$ & $\begin{array}{c}\text { DJl F550 } \\
\text { (hexacopter) }\end{array}$ & 50 & None & $\begin{array}{l}\text { Agisoft Photoscan } \\
\text { and ArcGIS }\end{array}$ & $\begin{array}{c}\text { Orthomosaic and } \\
\text { DEM }\end{array}$ & $\begin{array}{c}\text { Orthomosaic: } 3.5 \\
\text { DEM: } 4.5\end{array}$ & $\begin{array}{c}\text { Detection rate } 43- \\
80 \%\end{array}$ & No & . \\
\hline & $\begin{array}{l}\text { Wallace et } \\
\text { al., } 2016\end{array}$ & $\begin{array}{l}\text { Forest structure } \\
\text { assessment }\end{array}$ & Canon 550D (RGB) & $\begin{array}{c}\text { Droidworx } \\
\text { Skyjib } \\
\text { (octocopter) }\end{array}$ & 30 & None & $\begin{array}{l}\text { Agisoft Photoscan } \\
\text { Professional }\end{array}$ & Point cloud & 10 & $R^{2}=0.68 .0 .84$ & $\begin{array}{l}\text { Laser scanner } \\
\text { data }\end{array}$ & - \\
\hline
\end{tabular}




\begin{tabular}{|c|c|c|c|c|c|c|c|c|c|c|c|c|}
\hline & $\begin{array}{l}\text { Zarco- } \\
\text { Tejada et } \\
\text { al., } 2014\end{array}$ & $\begin{array}{l}\text { Tree height } \\
\text { quantification }\end{array}$ & $\begin{array}{l}\text { Modified Panasonic } \\
\text { Lumix DMC-GF1 } \\
\text { (CIR detection) }\end{array}$ & $\begin{array}{c}m X \text {-SIGHT } \\
\text { (fixed-wing) }\end{array}$ & 200 & None & Pix4D & $\begin{array}{c}\text { Ortho-mosaics and } \\
\text { DSMs }\end{array}$ & 5 & $R^{2}=0.83$ & No & - \\
\hline \multirow{7}{*}{$\begin{array}{l}\text { b. Yield and } \\
\text { nutrient } \\
\text { status }\end{array}$} & $\begin{array}{l}\text { Capolupo } \\
\text { et al., } 2015\end{array}$ & $\begin{array}{l}\text { Grassland } \\
\text { structural and } \\
\text { chemical trait } \\
\text { analysis }\end{array}$ & $\begin{array}{l}\text { Wageningen UR } \\
\text { Mapping System } \\
\text { (hyperspectral) }\end{array}$ & $\begin{array}{l}\text { Aerialtronics } \\
\text { Altura AT8 v1A } \\
\text { (octocopter) }\end{array}$ & 70 & $\begin{array}{l}\text { Multiple } \\
\text { narrow } \\
\text { vegetation } \\
\text { indices }\end{array}$ & - & - & $\begin{array}{l}\text { Hyperspectral: } 20 \\
\text { RGB: } 2\end{array}$ & $\begin{array}{c}\mathrm{R}^{2}=0-0.86 \text { (see } \\
\text { tables } 6 \text { and } 7 \text { in } \\
\text { manuscript) }\end{array}$ & No & $\begin{array}{l}\text { Comparison of } \\
\text { statistical } \\
\text { approaches: } \\
\text { partial least } \\
\text { squares } \\
\text { regression vs } \\
\text { narrow Vis. } \\
\text { 400-950nm } \\
\end{array}$ \\
\hline & $\begin{array}{l}\text { Geipel et } \\
\text { al., } 2014\end{array}$ & $\begin{array}{l}\text { Spectral and } \\
\text { spatial modeling } \\
\text { of corn yield }\end{array}$ & $\begin{array}{l}\text { Canon Ixus } 110 \text { IS } \\
\text { (RGB) }\end{array}$ & $\begin{array}{l}\text { Modified } \\
\text { MikroKopter } \\
\text { Hexa XL }\end{array}$ & 50 & $\begin{array}{l}\text { ExG, } \\
\text { NGRDI and } \\
\text { PPRb }\end{array}$ & Agisoft PhotoScan & $\begin{array}{l}\text { Vegetation index- } \\
\text { orthoimages and } \\
\text { 3D crop surface } \\
\text { models }\end{array}$ & $2-10$ & $\mathrm{R}^{2}$ of up to 0.74 & $\begin{array}{l}\text { Combined with } \\
\text { vegetation } \\
\text { index maps }\end{array}$ & $\begin{array}{l}\text { Three early- to } \\
\text { mid-season } \\
\text { growth stages }\end{array}$ \\
\hline & $\begin{array}{l}\text { Gong et al., } \\
2018\end{array}$ & $\begin{array}{l}\text { Estimation of } \\
\text { rapeseed yield }\end{array}$ & $\begin{array}{l}\text { Modified Tetracam } \\
\text { Mini-MCA } \\
\text { (multispectral) }\end{array}$ & $\begin{array}{l}\text { SZ DJI S1000 } \\
\text { (hexacopter) }\end{array}$ & 50 & $\begin{array}{l}\text { Multiple } \\
\text { vegetation } \\
\text { indices }\end{array}$ & - & - & 2.5 & $R^{2}=0.33-0.81$ & $\begin{array}{c}\text { In situ } \\
\text { hyperspectral } \\
\text { measures of } \\
\text { samples spectra }\end{array}$ & $\begin{array}{l}\text { Six spectral bands } \\
490-900 \mathrm{~nm} .\end{array}$ \\
\hline & $\begin{array}{l}\text { Kalisperakis } \\
\text { et al., } 2015\end{array}$ & $\begin{array}{l}\text { Leaf area index } \\
\text { estimation in } \\
\text { vineyards }\end{array}$ & $\begin{array}{l}\text { Headwall Photonics } \\
\text { Micro-A-Series } \\
\text { (hyperspectral) and } \\
\text { GoPro Hero3 (RGB) }\end{array}$ & $\begin{array}{l}\text { OnyxStar } \\
\text { multicopter } \\
\text { (octocopter) }\end{array}$ & $\begin{array}{l}\text { Not } \\
\text { specifie } \\
d\end{array}$ & $\begin{array}{l}\text { LAI, NDVI } \\
\text { and GRVI }\end{array}$ & $\begin{array}{c}\text { SfM for 2D } \\
\text { orthomosaics and } \\
\text { not specified } \\
\text { algorithms for } 3 \mathrm{D} \\
\text { canopy surface } \\
\text { models } \\
\end{array}$ & $\begin{array}{l}\text { 2D orthomosaics } \\
\text { and 3D canopy } \\
\text { surface models }\end{array}$ & Not specified & $R^{2}>73 \%$ & No & $380 \mathrm{~nm}-1000 \mathrm{~nm}$ \\
\hline & $\begin{array}{l}\text { Khaliq et } \\
\text { al., } 2019\end{array}$ & $\begin{array}{c}\text { Vineyard } \\
\text { variability } \\
\text { assessment }\end{array}$ & $\begin{array}{l}\text { Parrot sequoia } \\
\text { (multispectral) }\end{array}$ & Octocopter & 35 & NDVI & Agisoft Photoscan & NDVI maps & 5 & - & $\begin{array}{l}\text { Compared to } \\
\text { satellite } \\
\text { multispectral } \\
\text { imagery }\end{array}$ & $\begin{array}{l}\text { UAV-NDVI maps } \\
\text { significantly } \\
\text { predicted three } \\
\text { vigor classes }\end{array}$ \\
\hline & $\begin{array}{l}\text { Lelong et } \\
\text { al. } 2008\end{array}$ & $\begin{array}{l}\text { Quantitative } \\
\text { monitoring of } \\
\text { wheat crop }\end{array}$ & $\begin{array}{c}\text { CANON EOS 350D } \\
\text { (RGB) and SONY } \\
\text { DSC-F828 (Red, } \\
\text { Green, Blue, and } \\
\text { Cyan). }\end{array}$ & $\begin{array}{l}\text { L'Avion Jaune } \\
\text { powered glider } \\
\text { (fixed-wing) } \\
\text { and ABS- } \\
\text { Aerolight } \\
\text { motorized } \\
\text { parachute } \\
\end{array}$ & $20-100$ & $\begin{array}{l}\text { NDVI, SAVI } \\
\text {, GNDVI } \\
\text { and GI }\end{array}$ & Not specified & $\begin{array}{l}\text { LAI and nitrogen } \\
\text { uptake maps }\end{array}$ & 10 & $R^{2}=0.82-0.92$ & No & - \\
\hline & $\begin{array}{l}\text { Liu et al. } \\
2018\end{array}$ & $\begin{array}{l}\text { Nitrogen status } \\
\text { diagnosis in } \\
\text { winter oilseed } \\
\text { rape }\end{array}$ & $\begin{array}{l}\text { Mini-MCA } 6 \\
\text { (multispectral) }\end{array}$ & $\begin{array}{l}\text { SZ DJI S1000 } \\
\text { (hexacopter) }\end{array}$ & 40 & $\begin{array}{c}\text { NDVI, } \\
\text { VARI, } \\
\text { MSAVI2, } \\
\text { Cired edge, } \\
\text { RVI1, RVI2 }\end{array}$ & $\begin{array}{c}\text { Agisoft Photoscan } \\
\text { Pro }\end{array}$ & Orthomosaics & 2.2 & $R^{2}=0.45-0.83$ & $\begin{array}{c}\text { Ground } \\
\text { sampling } \\
\text { campaigns. LAI } \\
\text { and oilseed } \\
\text { rape spectra } \\
\text { measured } \\
\text { (hyperspectral } \\
\text { data) }\end{array}$ & - \\
\hline
\end{tabular}




\begin{tabular}{|c|c|c|c|c|c|c|c|c|c|c|c|c|}
\hline & $\begin{array}{l}\text { Potgieter et } \\
\text { al., } 2017\end{array}$ & $\begin{array}{l}\text { Assessment of } \\
\text { sorghum leaf } \\
\text { area dynamics }\end{array}$ & $\begin{array}{c}\text { MicaSense } \\
\text { RedEdgeTM } \\
\text { (multispectral) }\end{array}$ & $\begin{array}{l}\text { 3D Robotics } \\
\text { X8+ multi- } \\
\text { rotor } \\
\text { (quadcopter) }\end{array}$ & 20 & $\begin{array}{l}\text { LAI, NDVI, } \\
\text { EVI and } \\
\text { NDRE }\end{array}$ & Pix4D & $\begin{array}{l}\text { Geo-referenced } \\
\text { multi-layer } \\
\text { orthomosaic }\end{array}$ & 0.5 & $R^{2}=0.19-0.85$ & No & - \\
\hline & $\begin{array}{l}\text { Rey- } \\
\text { Caramés et } \\
\text { al., } 2015\end{array}$ & $\begin{array}{c}\text { Vineyard } \\
\text { variability } \\
\text { characterization }\end{array}$ & $\begin{array}{l}\text { MCA-6 Tetracam } \\
\text { (multispectral) }\end{array}$ & $\begin{array}{l}\text { RPAS Md4- } \\
1000 \\
\text { (quadcopter) }\end{array}$ & 250 & $\begin{array}{l}\text { Multiple } \\
\text { indices }\end{array}$ & ENVI & Orthomosaic & 17 & $R^{2}=0.32-0.69$ & No & - \\
\hline & $\begin{array}{l}\text { Sanches et } \\
\text { al., } 2018\end{array}$ & $\begin{array}{l}\text { Sugarcane yield } \\
\text { prediction }\end{array}$ & $1 / 2.3^{\prime \prime} \mathrm{CMOS}$ (RGB) & $\begin{array}{l}\text { DJI Phantom } 3 \\
\text { (quadcopter) }\end{array}$ & 25 & $\begin{array}{l}\text { LAl and } \\
\text { GRVI }\end{array}$ & Drone Deploy & Orthomosaic & 5 & $\begin{aligned} R^{2} G R V I & =0.69 \\
R^{2} L A I & =0.34 \\
R^{2} G R V I+L A I & =0.79\end{aligned}$ & No & - \\
\hline & $\begin{array}{l}\text { Zarco- } \\
\text { Tejada et } \\
\text { al., } 2013\end{array}$ & $\begin{array}{l}\text { Leaf carotenoid } \\
\text { estimation in } \\
\text { vineyards }\end{array}$ & $\begin{array}{c}\text { MCA-6 Tetracam } \\
\text { (multispectral) and } \\
\text { Micro-Hyperspec } \\
\text { VNIR } \\
\text { (hyperspectral) }\end{array}$ & $\begin{array}{c}\text { mX-SIGHT } \\
\text { (fixed-wing) } \\
\text { and ELIMCO } \\
\text { Viewer (fixed- } \\
\text { wing) }\end{array}$ & $\begin{array}{c}150 \\
\text { (multisp } \\
\text { ectral) } \\
\text { and } 575 \\
\text { (hypersp } \\
\text { ectral) } \\
\end{array}$ & $\begin{array}{c}\text { LAI, } \\
\text { R515/R57 } \\
0 \text { and } \\
\text { TCARI/OS } \\
\text { AVI }\end{array}$ & PARGE & $\begin{array}{l}\text { Ortho-rectified } \\
\text { hyperspectral } \\
\text { scenes }\end{array}$ & $\begin{array}{c}15 \text { for multispectral } \\
\text { and } \\
40 \text { for } \\
\text { hyperspectral }\end{array}$ & $R^{2}=0.5-0.99$ & No & - \\
\hline & $\begin{array}{l}\text { Zhou et al., } \\
2017\end{array}$ & $\begin{array}{l}\text { Rice yield } \\
\text { prediction }\end{array}$ & $\begin{array}{l}\text { EOS 5D Mark III } \\
\text { (RGB) and Mini- } \\
\text { MCA6 } \\
\text { (multispectral) }\end{array}$ & $\begin{array}{l}\text { HiSystems MK } \\
\text { (octocopter) }\end{array}$ & $\begin{array}{c}100 \\
\text { (multisp } \\
\text { ectral) } \\
\text { and 50 } \\
\text { (RGB) }\end{array}$ & $\begin{array}{l}\text { Multiple } \\
\text { indices }\end{array}$ & $\begin{array}{l}\text { IDL script within } \\
\text { ENVI and Agisoft } \\
\text { PhotoScan } \\
\text { Professional }\end{array}$ & Orthomosaic & $\begin{array}{l}5.4 \text { for } \\
\text { multispectral and } \\
\sim 2 \text { for RGB }\end{array}$ & $R^{2}=0.33-0.79$ & $\begin{array}{c}\text { Target's } \\
\text { reflectance } \\
\text { measured with } \\
\text { a FieldSpec } 4 \\
\text { Spectroradiome } \\
\text { ter } \\
\end{array}$ & - \\
\hline \multirow[b]{4}{*}{ c. Pest and } & $\begin{array}{l}\text { Calderón et } \\
\text { al., } 2014\end{array}$ & $\begin{array}{l}\text { Downy mildew } \\
\text { detection in } \\
\text { opium poppy }\end{array}$ & $\begin{array}{c}\text { ADC Lite Tetracam } \\
\text { (multispectral) and } \\
\text { MIRICLE } 307 \\
\text { (thermal) }\end{array}$ & $\begin{array}{c}m X \text {-SIGHT } \\
\text { (fixed-wing) }\end{array}$ & $\begin{array}{c}200 \\
\text { (multisp } \\
\text { ectral) } \\
\text { and } 100 \\
\text { (thermal } \\
\text { ) }\end{array}$ & $\begin{array}{l}\text { NDVI and } \\
\text { R550/R67 } \\
0\end{array}$ & Not specified & $\begin{array}{l}\text { Multispectral and } \\
\text { thermal scenes }\end{array}$ & 20 & - & $\begin{array}{l}\text { Reflectance of } \\
\text { attacked leaves } \\
\text { measured with } \\
\text { Li-Cor } 1800-12 \\
\text { Integrating } \\
\text { Sphere } \\
\text { spectrometer } \\
\end{array}$ & - \\
\hline & $\begin{array}{l}\text { Cardil et al., } \\
\quad 2017\end{array}$ & $\begin{array}{c}\text { Pine- } \\
\text { processionary- } \\
\text { moth } \\
\text { defoliation } \\
\text { assessment }\end{array}$ & RGB & $\begin{array}{l}\text { DJI Phantom } 3 \\
\text { (quadcopter) }\end{array}$ & $80-100$ & None & $\begin{array}{l}\text { Agisoft PhotoScan } \\
\text { Professional }\end{array}$ & $\begin{array}{l}\text { Point clouds, 3D } \\
\text { reconstruction, } \\
\text { orthomosaic, } \\
\text { DSMs, DEM and } \\
\text { CHM }\end{array}$ & $1.5-2.5$ & $\begin{array}{c}\text { Overall accuracy } \\
79 \% . \\
\mathrm{R}^{2}=0.55 \text { of linear } \\
\text { regression model }\end{array}$ & No & $\begin{array}{l}\text { Videos at } 20 \mathrm{~m} \\
\quad \text { altitude } \\
\text { for validation }\end{array}$ \\
\hline & $\begin{array}{l}\text { Del-Campo- } \\
\text { Sanchez et } \\
\text { al., } 2019\end{array}$ & $\begin{array}{c}\text { Pest } \\
\text { quantification in } \\
\text { vineyards }\end{array}$ & $\begin{array}{c}\text { SONY } \alpha \text { |lLCE-5100L } \\
\text { (RGB) }\end{array}$ & $\begin{array}{c}\text { microdrone } \\
\text { md4-1000 } \\
\text { (quadcopter) }\end{array}$ & 80 & None & $\begin{array}{l}\text { Agisoft PhotoScan } \\
\text { and LAIC }\end{array}$ & $\begin{array}{l}\text { Point clouds, } \\
\text { orthomosaics and } \\
\text { affection maps }\end{array}$ & 1.5 & $\begin{array}{c}\text { Overall accuracy } \\
\text { radiometric } 79 \% . \\
\text { Overall accuracy } \\
\text { radiometric }+ \\
\text { geometric } 99.3 \% .\end{array}$ & $\begin{array}{l}5 \mathrm{~m} \text { resolution } \\
\text { DEM used }\end{array}$ & $\begin{array}{l}\text { The automated } \\
\text { identification of } \\
\text { affected } \\
\text { vegetation with } \\
\text { LAIC }\end{array}$ \\
\hline & $\begin{array}{l}\text { Garcia-Ruiz } \\
\text { et al., } 2013\end{array}$ & $\begin{array}{l}\text { Infected citrus } \\
\text { trees } \\
\text { identification }\end{array}$ & $\begin{array}{c}\text { miniMCA6 } \\
\text { Tetracam } \\
\text { (multispectral) }\end{array}$ & $\begin{array}{l}\text { HiSystems } \\
\text { GmbH } \\
\text { (hexacopter) }\end{array}$ & 100 & $\begin{array}{l}\text { Seven } \\
\text { vegetation } \\
\text { indices }\end{array}$ & $\begin{array}{l}\text { PixelWrench2, } \\
\text { ENVI, Matlab }\end{array}$ & $\begin{array}{l}\text { Georeferenced } \\
\text { false color images }\end{array}$ & 5.45 & $\begin{array}{c}\text { Overall accuracy } \\
67-85 \% .\end{array}$ & No & $\begin{array}{c}\text { Compared with } \\
50 \mathrm{~cm} / \text { pixel } \\
\text { airborne } \\
\text { hyperspectral } \\
\text { images }\end{array}$ \\
\hline
\end{tabular}




\begin{tabular}{|c|c|c|c|c|c|c|c|c|c|c|c|c|}
\hline \multirow[t]{4}{*}{$\begin{array}{l}\text { pathogen } \\
\text { damage }\end{array}$} & $\begin{array}{l}\text { Moriya et } \\
\text { al., } 2017\end{array}$ & $\begin{array}{l}\text { Sugarcane } \\
\text { mosaic virus } \\
\text { mapping }\end{array}$ & $\begin{array}{c}\text { DT-0014 } \\
\text { Fabry-Perot } \\
\text { Interferometer } \\
\text { (hyperspectral) and } \\
\text { Ultracam-XP (RGB) }\end{array}$ & $\begin{array}{c}\text { SX8 multirotor } \\
\text { UAS } \\
\text { (octocopter) }\end{array}$ & 160 & None & $\begin{array}{l}\text { Radiometric } \\
\text { processing done } \\
\text { with BRDF model. } \\
\text { Classification } \\
\text { Process with } \\
\text { spectral } \\
\text { information } \\
\text { divergence (SID) } \\
\text { in ENVI }\end{array}$ & $\begin{array}{l}\text { Orthomosaic and } \\
\text { digital surface } \\
\text { model }\end{array}$ & $\begin{array}{c}11 \text { for } \\
\text { hyperspectral } \\
\text { images. } \\
40 \text { for RGB camera. } \\
50 \text { for DSM and } \\
\text { orthomosaic }\end{array}$ & $\begin{array}{c}\text { Overall accuracy } \\
92.5 \% .\end{array}$ & $\begin{array}{l}\text { Spectral library } \\
\text { of sick and } \\
\text { healthy leaves } \\
\text { made with an } \\
\text { ASD handheld } \\
\text { FieldSpec } \\
\text { UV/NIR } \\
\text { spectroradiome } \\
\text { ter }\end{array}$ & $\begin{array}{l}\text { Up to } 25 \text { bands } \\
\text { from selectable } \\
\text { wavelengths. } \\
\text { spectral range } \\
500-900 \mathrm{n}\end{array}$ \\
\hline & $\begin{array}{l}\text { Sugiura et } \\
\text { al., } 2016\end{array}$ & $\begin{array}{l}\text { Assessment of } \\
\text { potato late } \\
\text { blight resistance }\end{array}$ & $\begin{array}{c}\text { Sony } \\
\text { NEX-5N (RGB) }\end{array}$ & $\begin{array}{l}\text { HiSystems } \\
\text { GmbH } \\
\text { Mikrokopter } \\
\text { (quadcopter) }\end{array}$ & 80 & None & Not specified & $\begin{array}{l}\text { Potato damage } \\
\text { maps }\end{array}$ & 2.4 & $R^{2}=0.73-0.77$ & No & - \\
\hline & $\begin{array}{l}\text { Tetila et al., } \\
2017\end{array}$ & $\begin{array}{l}\text { Identification of } \\
\text { Soybean Foliar } \\
\text { Diseases }\end{array}$ & Sony EXMOR (RGB) & $\begin{array}{l}\text { DJI Phantom } 3 \\
\text { (quadcopter) }\end{array}$ & $1-16$ & None & $\begin{array}{l}\text { Visual } \\
\text { classification of } \\
\text { superpixels }\end{array}$ & $\begin{array}{l}\text { Disease } \\
\text { classification maps }\end{array}$ & $0.043-0.691$ & $\begin{array}{c}\text { Overall accuracy } \\
98.34 \% .\end{array}$ & No & $\begin{array}{l}\text { Uses SLIC } \\
\text { superpixels } \\
\text { algorithm for } \\
\text { segmentation }\end{array}$ \\
\hline & $\begin{array}{l}\text { Vanegas et } \\
\text { al., } 2018\end{array}$ & $\begin{array}{l}\text { Plant pest } \\
\text { surveillance in } \\
\text { vineyards }\end{array}$ & $\begin{array}{c}\text { Canon 5DsR } \\
\text { camera (RGB), } \\
\text { MicaSense } \\
\text { RedEdge } \\
\text { (multispectral) and } \\
\text { Headwall Nano- } \\
\text { Hyperspec } \\
\text { (hyperspectral) } \\
\end{array}$ & $\begin{array}{l}\text { S800 EVO } \\
\text { (hexacopter) }\end{array}$ & $60-100$ & $\begin{array}{l}\text { Multiple } \\
\text { indices }\end{array}$ & $\begin{array}{l}\text { Agisoft Photoscan, } \\
\text { Headwall } \\
\text { SpectralViewer, } \\
\text { MATLAB, Scyllarus } \\
\text { and ArcMap }\end{array}$ & $\begin{array}{l}\text { 3D models, } \\
\text { orthomosaics, DSM } \\
\text { and DVM }\end{array}$ & $\begin{array}{l}3.26-6.74 \text { for } \\
\text { multispectral } \\
\text { imagery }\end{array}$ & $\begin{array}{c}\text { positive } \\
\text { correlation ( } r> \\
0.4 \text { ) with } 7 \\
\text { different indices }\end{array}$ & $\begin{array}{l}\text { Google Earth } \\
\text { imagery }\end{array}$ & - \\
\hline \multirow{4}{*}{ d. Soil fertility } & $\begin{array}{l}\text { Aldana- } \\
\text { Jague et al., } \\
\text { 2016b }\end{array}$ & $\begin{array}{l}\text { Soil carbon } \\
\text { mapping }\end{array}$ & $\begin{array}{l}\text { Mini-MCA6 } \\
\text { (multispectral) }\end{array}$ & $\begin{array}{c}\text { Mikrokopter- } \\
\text { XL } \\
\text { (octocopter) }\end{array}$ & 100 & None & $\begin{array}{c}\text { AutoPano Giga } \\
\text { and ArcGISTM. } \\
\text { Support Vector } \\
\text { Machine (SVM) } \\
\text { algorithm to } \\
\text { predict SOC from } \\
\text { the soil spectra in } \\
\text { R } \\
\end{array}$ & Orthomosaic & 12 & $\mathrm{R}^{2}>0.9$ & No & $\begin{array}{c}\text { Six spectral bands } \\
450-1050 \mathrm{~nm}\end{array}$ \\
\hline & $\begin{array}{l}\text { Bazzoffi, } \\
2015\end{array}$ & $\begin{array}{l}\text { Rill erosion } \\
\text { measurement }\end{array}$ & SONY NEX-5 (RGB) & $\begin{array}{l}\text { Falcon } 8 \\
\text { (octocopter) }\end{array}$ & 30 & None & $\begin{array}{c}\text { Agisoft } \\
\text { PhotoScan Pro } \\
\text { and ESri ArcGis }\end{array}$ & $\begin{array}{l}\text { Digital elevation } \\
\text { model }\end{array}$ & $1-6$ & $R 2=0.87$ & No & - \\
\hline & $\begin{array}{l}\text { d'Oleire- } \\
\text { Oltmanns } \\
\text { et al., } 2012\end{array}$ & $\begin{array}{l}\text { Soil erosion } \\
\text { monitoring }\end{array}$ & $\begin{array}{l}\text { Panasonic Lumix } \\
\text { GF1 (RGB) }\end{array}$ & $\begin{array}{l}\text { Sirius I (fixed- } \\
\quad \text { wing) }\end{array}$ & $70-400$ & None & $\begin{array}{l}\text { Leica } \\
\text { Photogrammetry } \\
\text { Suite and MAVinci }\end{array}$ & $\begin{array}{l}\text { Digital Terrain } \\
\text { Models (DTMs) and } \\
\text { orthomosaics }\end{array}$ & $\sim 1-10$ & Not specified & No & $\begin{array}{l}\text { Coordinates for } \\
\text { well-defined } \\
\text { points, were } \\
\text { taken from a } \\
\text { Quickbird } \\
\text { satellite scene } \\
\end{array}$ \\
\hline & $\begin{array}{l}\text { Estrany et } \\
\text { al., } 2019\end{array}$ & $\begin{array}{c}\text { Ecosystem } \\
\text { dynamics } \\
\text { assessment and } \\
\text { management }\end{array}$ & $\begin{array}{l}\text { Canon PowerShot } \\
\text { ELPH } 110 \mathrm{HS} \\
\text { (multispectral) }\end{array}$ & $\begin{array}{l}\text { Mikrocopter } \\
\text { (hexacopter) }\end{array}$ & 52 & BNDVI & $\begin{array}{l}\text { Agisoft Photoscan } \\
\text { Professional and } \\
\text { ArcGIS }\end{array}$ & $\begin{array}{c}\text { Orthomosaic and } \\
\text { DEMs }\end{array}$ & 1.4 & Not specified & No & $\begin{array}{l}\text { MATLAB for } \\
\text { image processing }\end{array}$ \\
\hline
\end{tabular}




\begin{tabular}{|c|c|c|c|c|c|c|c|c|c|c|c|c|}
\hline & $\begin{array}{l}\text { Ge et al., } \\
2019\end{array}$ & $\begin{array}{l}\text { Soil moisture } \\
\text { monitoring }\end{array}$ & $\begin{array}{c}\text { Headwall Nano- } \\
\text { Hyperspec } \\
\text { (hyperspectral) }\end{array}$ & $\begin{array}{l}\text { DJI Matrice } \\
600 \text { Pro } \\
\text { (hexacopter) }\end{array}$ & 100 & $\begin{array}{c}30 \\
\text { different } \\
\text { indices }\end{array}$ & $\begin{array}{l}\text { Image smoothing } \\
\text { and model } \\
\text { calibration, } \\
\text { evaluation and } \\
\text { comparison in } \\
\text { MATLAB }\end{array}$ & Orthomosaic & 4 & $\begin{array}{c}\mathrm{R} 2=0.15-0.66 \text { for } \\
\text { common spectral } \\
\text { indices. } \\
\mathrm{R}^{2}=0.91 \text { for } \\
\text { perpendicualr } \\
\text { index random } \\
\text { forest }\end{array}$ & No & $\begin{array}{c}\text { Spectrometer } \\
\text { range } 400-1000 \\
\mathrm{~nm} .\end{array}$ \\
\hline & $\begin{array}{l}\text { Kavoosi et } \\
\text { al., } 2018\end{array}$ & $\begin{array}{l}\text { Soil residue } \\
\text { cover } \\
\text { monitoring }\end{array}$ & Sony EXMOR (RGB) & $\begin{array}{l}\text { DJI Phantom } 3 \\
\text { professional } \\
\text { (quadcopter) }\end{array}$ & $5-10$ & $\begin{array}{c}14 \\
\text { different } \\
\text { visible } \\
\text { spectrum } \\
\text { indices }\end{array}$ & $\begin{array}{c}\text { RGB bands } \\
\text { separated with } \\
\text { MATLAB. Spectral } \\
\text { indices calculated } \\
\text { in Excell }\end{array}$ & None & $0.23-0.45$ & $\mathrm{R} 2=0.84$ & $\begin{array}{l}\text { Landsat } 8 \text { OLI } \\
\text { data (satellite) }\end{array}$ & - \\
\hline & $\begin{array}{l}\text { Sugiura et } \\
\text { al., } 2007\end{array}$ & $\begin{array}{l}\text { Soil water status } \\
\text { estimation }\end{array}$ & Thermal camera & $\begin{array}{l}\text { Unmanned } \\
\text { helicopter }\end{array}$ & 40 & None & $\begin{array}{l}\text { Used a correction } \\
\text { model to get real } \\
\text { temperature } \\
\text { values based on } \\
\text { emissivity and } \\
\text { transmissivity. }\end{array}$ & $\begin{array}{c}\text { Thermal infrared } \\
\text { maps }\end{array}$ & $\sim 12$ & $R 2=0.62-0.69$ & No & $\begin{array}{l}\text { Ground-truth } \\
\text { measurement }\end{array}$ \\
\hline & $\begin{array}{l}\text { Wang et al., } \\
2016\end{array}$ & $\begin{array}{l}\text { Gully erosion } \\
\text { mapping and } \\
\text { monitoring }\end{array}$ & Sony EXMOR (RGB) & $\begin{array}{l}\text { Phantom } 3 \\
\text { Professional } \\
\text { (quadcopter) }\end{array}$ & 120 & None & $\begin{array}{l}\text { Pix4Dmapper and } \\
\text { ArcGIS }\end{array}$ & $\begin{array}{c}\text { Orthomosaic and } \\
\text { DSM }\end{array}$ & 4.4 & $\begin{array}{c}\text { Overall accuracy } \\
90 \% .\end{array}$ & $\begin{array}{l}\text { Pleiades-1A } \\
\text { imagery (satellit } \\
\text { e) }\end{array}$ & - \\
\hline \multirow{5}{*}{$\begin{array}{l}\text { e. Weeds and } \\
\text { other non- } \\
\text { crop plants }\end{array}$} & $\begin{array}{l}\text { Castaldi et } \\
\text { al., } 2017\end{array}$ & $\begin{array}{l}\text { Maize herbicide } \\
\text { spraying } \\
\text { analysis }\end{array}$ & $\begin{array}{l}\text { Modified Canon } \\
\text { s110 (multispectral) } \\
\text { and AIRINOV } \\
\text { Agrosensor } \\
\text { (multispectral) }\end{array}$ & $\begin{array}{l}\text { eBee (fixed- } \\
\text { wing) and SF6 }\end{array}$ & $\begin{array}{c}150 \text { and } \\
35\end{array}$ & $\begin{array}{l}\text { LAI and } \\
\text { NDVI }\end{array}$ & $\begin{array}{l}\text { Support vector } \\
\text { machine } \\
\text { algorithm in ENVI } \\
\text { CAN-EYE to } \\
\text { calculate LAI }\end{array}$ & $\begin{array}{l}\text { Weed, prescription } \\
\text { and biomass maps. }\end{array}$ & $8-9$ and 5 & $\mathrm{R} 2 \geq 0.80$ & No & - \\
\hline & $\begin{array}{l}\text { Pantazi et } \\
\text { al., } 2017\end{array}$ & Weed mapping & $\begin{array}{l}\text { Canon S110 } \\
\text { (NIR sensor) }\end{array}$ & $\begin{array}{l}\text { eBee (fixed- } \\
\text { wing) }\end{array}$ & 115 & None & Pix4Dmapper Pro & $\begin{array}{l}\text { Orthomosaic, point } \\
\text { cloud and DSM. }\end{array}$ & 50 & $>98 \%$ & No & - \\
\hline & $\begin{array}{l}\text { Peña et al., } \\
2013\end{array}$ & $\begin{array}{l}\text { Maize weeds } \\
\text { mapping }\end{array}$ & $\begin{array}{l}\text { Tetracam mini- } \\
\text { MCA-6 camera } \\
\text { (multispectral) }\end{array}$ & $\begin{array}{c}\text { md4-1000 } \\
\text { (quadcopter) }\end{array}$ & 30 & NDVI & $\begin{array}{l}\text { PixelWrench2 and } \\
\text { eCognition } \\
\text { Developer }\end{array}$ & $\begin{array}{l}\text { OBIA output (geo- } \\
\text { referenced weed } \\
\text { map) }\end{array}$ & 2 & $R 2=0.89$ & No & - \\
\hline & $\begin{array}{l}\text { Peña et al., } \\
2015\end{array}$ & $\begin{array}{l}\text { Weed seedling } \\
\text { detection }\end{array}$ & $\begin{array}{l}\text { Olympus PEN E- } \\
\text { PM1 (RGB) and } \\
\text { Tetracam mini- } \\
\text { MCA-6 camera } \\
\text { (multispectral) }\end{array}$ & $\begin{array}{l}\text { md4-1000 } \\
\text { (quadcopter) }\end{array}$ & $40-100$ & NDVI & $\begin{array}{l}\text { eCognition } \\
\text { Developer and } \\
\text { Agisoft Photoscan } \\
\text { Professional }\end{array}$ & $\begin{array}{l}\text { Orthomosaic and } \\
\text { OBIA output (geo- } \\
\text { referenced weed } \\
\text { map) }\end{array}$ & $\begin{array}{c}\text { RGB: } 1.52-3.81 \\
\text { Multiscpectral: } \\
2.16-5.41\end{array}$ & $\begin{array}{c}\text { RGB: } 19-71 \% \\
\text { accuracy } \\
\text { Multispectral: } 43- \\
\text { 71\% accuracy }\end{array}$ & No & - \\
\hline & $\begin{array}{l}\text { Pérez-Ortiz } \\
\text { et al., } 2015\end{array}$ & $\begin{array}{c}\text { Sunflower } \\
\text { weeds mapping }\end{array}$ & $\begin{array}{l}\text { Olympus PEN E- } \\
\text { PM1 (RGB) and } \\
\text { Tetracam mini- } \\
\text { MCA-6 camera } \\
\text { (multispectral) }\end{array}$ & $\begin{array}{l}\text { md4-1000 } \\
\text { (quadcopter) }\end{array}$ & $30-100$ & $\begin{array}{l}\text { NDVI and } \\
\text { ExG }\end{array}$ & $\begin{array}{l}\text { Agisoft Photoscan } \\
\text { Professional }\end{array}$ & Orthomosaic & $\begin{array}{c}\text { RGB: } 1-4 \\
\text { Multiscpectral: } 2-5\end{array}$ & $75 \%$ & No & - \\
\hline
\end{tabular}


Definitions: Ground sampling distance (GSD), digital terrain model (DTM), digital surface model (DSM), digital vigour model (DVM), digital elevation model (DEM), habitat suitability model (HSM), crop surface model (CSM), canopy height model (CHM), area under the receiver operating characteristic curve (AUC), point-biserial correlation coefficient (COR), colour infrared (CIR), Near infra-red (NIR), vegetation indices (VIs), gap shape complexity index (GSCI), green-red vegetation index (GRVI), excess green index (ExG), normalized green-red difference index (NGRDI), plant pigment ratio (PPRb), normalized difference vegetation index (NDVI), blue normalized difference vegetation index (BNDVI), enhanced vegetation index (EVI) and normalized difference red edge index (NDRE), soil-adjusted vegetation index (SAVI), green normalized difference vegetation index (GNDVI), greenness index (GI), visible atmospherically resistance index (VARI), modified soil adjusted vegetation index 2 (MSAVI2), red edge chlorophyll index (CIred edge), ratio vegetation index 1 (RVI1), ratio vegetation index 2 (RVI2), structure from motion (SfM), ground control points (GCPs), microbolometer optimization (MbOpt), Leaf Area Index Calculation software (LAIC), Simple Linear Iterative Clustering (SLIC).

Software details: Agisoft Photoscan and Pix4D are used for mosaicking and orthorectification. ArcGIS and ENVI allow geometric and radiometric correction, respectively. Adobe Photoshop permits image merging. 


\section{Chapter 2}

\section{A plant-pollinator metanetwork along a habitat fragmentation gradient}

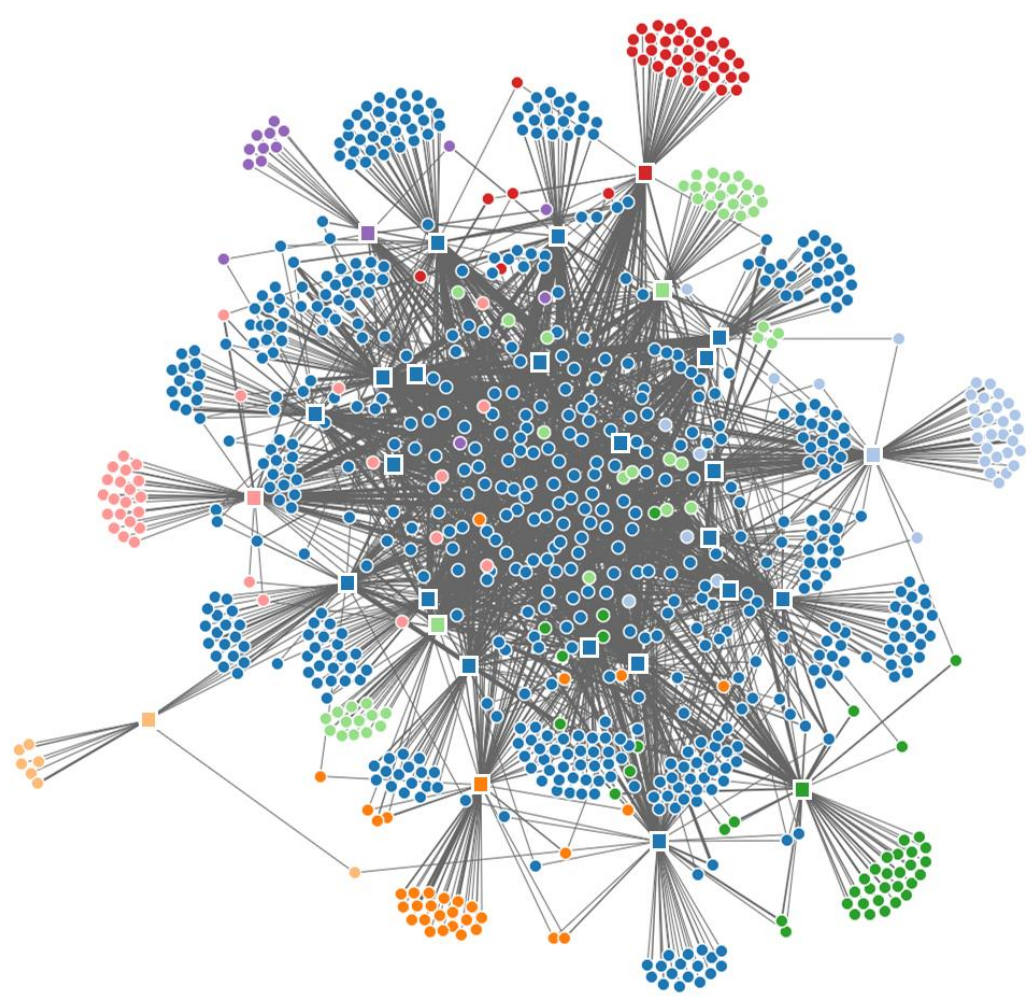

Felipe Librán-Embid, Ingo Grass, Carine Emer, Cristina Ganuza \& Teja Tscharntke 


\begin{abstract}
To understand how plant-pollinator interactions respond to habitat fragmentation we need novel approaches that can capture properties that emerge at broad scales, where species engage across multiple communities in metanetworks. Here we studied plant-pollinator interactions over two years on 29 calcareous grassland fragments selected along independent gradients of habitat size and surrounding landscape diversity. We associated the centrality of plant-pollinator interactions and grassland fragments with their traits. Interactions involving habitat specialist plants and large-bodied pollinators were the most central, implying that species with these traits form the metanetwork core, maintaining its integrity. Large fragments embedded in landscapes with high land cover diversity exhibited the highest centrality; however, small fragments harbored a high share of unique interactions not found on larger fragments. Our results emphasize the need to keep a conservation focus on both small and large habitat fragments as well as on landscape diversification.
\end{abstract}




\section{Introduction}

To understand the impacts of global change on species survival and community composition, we need to look beyond the species richness level and incorporate the fact that all species are connected by ecological interactions (Valiente-Banuet et al., 2015). Ecosystem functions and services, many of which are essential to human well-being, are underpinned by species interactions (Galetti et al., 2013; Traill et al., 2010). Plant-pollinator interactions, for example, are mutualistic associations fundamental to the reproductive success of $88 \%$ of all flowering plants and consequently to the functioning of natural and agricultural systems (Ollerton et al., 2011). Plant-pollinator interactions organize themselves in intricate networks based on the local plant and pollinator pools (Bascompte et al., 2003; Delmas et al., 2019; Memmott, 1999). Studying the properties of these networks gives information about their functionality and stability, which

ultimately determines species persistence (Burkle et al., 2013; Landi et al., 2018). Understanding changes in ecological networks following habitat fragmentation, from local community to broader metacommunity levels, would greatly advance basic knowledge needed for successful species conservation (Emer et al., 2018; Tylianakis et al., 2010; Tylianakis and Morris, 2017).

The effects of habitat fragmentation on plant-pollinator networks have been studied to some extent (Ferreira et al., 2013; Pellissier et al., 2018). Most studies have used bipartite approaches at local scales that have helped to understand network changes in terms of structure and stability (Grass et al., 2018; Spiesman and Inouye, 2013). However, local approaches cannot capture the properties of plant-pollinator interactions emerging at broader scales, where species engage across multiple communities in metacommunities (Hagen et al., 2012). To overcome this limitation, plant-pollinator interactions can be studied in a metanetwork framework in which local communities are connected by the interactions they share (Emer et al., 2018). From a conservation perspective, it is fundamental to identify and protect the most important nodes within a metanetwork (i.e. central interactions or habitats, Emer et al., 2018). Node importance can be quantified through the concept of node "centrality" (Jordán, 2009). Central nodes are those that maintain network cohesiveness and stability, and, when lost, have the strongest detrimental effects for the whole structure of the network (Estrada, 2007; Freeman, 1978; González et al., 2010). The loss of central nodes can lead to the breakdown of a spatial metanetwork resulting in isolated communities and the extirpation of ecological functions at the landscape level (Emer et al., 2018). 
Species traits determine their centrality in local networks (Morán-López et al., 2020). Likewise, trait combinations of interacting partners may determine the centrality of an interaction within a metanetwork perspective. Among the different species traits that can be related to centrality, body size and habitat specialization are of particular ecological importance (Grass et al., 2018). For instance, wing and body size are correlated with flying capacity in bees and butterflies (Gathmann and Tscharntke, 2002; Stevens et al., 2013; Westphal et al., 2006). In a scenario of habitat fragmentation and low-risk matrix (Fahrig, 2007), large species would be expected to be able to cross the matrix and use habitat patches that are out of reach for smaller species (Thomas et al., 1992). High habitat specialization entails that a given species is mostly restricted to a certain habitat (Segura et al., 2007). Therefore, at the landscape level, habitat specialists cannot establish viable populations in the matrix, being restricted to available habitat fragments. Habitat specialization and body size can thus be used to identify key interactions of metanetworks, as well as to identify changes in plant-pollinator interactions caused by habitat fragmentation at the landscape scale.

In addition, the metanetwork approach can be used to identify key traits of habitat fragments that are fundamental to maintain metacommunity cohesiveness. Fragment size and fragment spatial connectivity (i.e. measure of proximity to other sites) could predict fragment centrality, as these characteristics are related to the number of individuals that a certain fragment can support and to the frequency of immigration events, respectively (Hanski and Ovaskainen, 2000; SteffanDewenter and Tscharntke, 2002). Furthermore, the characteristics of the matrix in the surroundings of a fragment can also influence fragment centrality, given that the matrix composition affects available food resources and is known to affect the capacity of organisms to cross it (Boesing et al., 2018; Nowicki et al., 2014; van Halder et al., 2017).

Here we studied plant-pollinator interactions along a habitat fragmentation gradient in calcareous grasslands, which are threatened hotspots of plant and pollinator diversity in Europe (Habel et al., 2013). We identified central plant-pollinator interactions in a metanetwork context and related these to the traits of the species involved in those interactions. We also explored the characteristics of the most central habitat fragments that maintain metanetwork cohesiveness at the regional level. 
We hypothesized that: (i) the overall metanetwork structure will be poorly connected and highly modular because of the presence of many interactions performed by small-sized species, not able to cross the matrix and therefore restricted to single fragments; (ii) interactions involving habitat specialist species are more central than those involving habitat generalists, because habitat specialist are better adapted to exploit the resources of calcareous grasslands, as they depend exclusively on them across the fragmented landscape; (iii) interactions involving large-bodied pollinators are more central than those involving small-bodied ones, given that large-bodied species can exploit resources at greater distances and potentially cross the matrix, and that (iv) larger-sized and more connected fragments with higher diversity of cover types in the surrounding landscape show higher centrality.

\section{Methods}

Study system

Calcareous grasslands are the most species-rich habitats in central Europe and are therefore considered biodiversity hotspots (Habel et al., 2013; van Swaay, 2002). Once widely spread, they have been greatly reduced due to agricultural intensification and the abandonment of the historically common extensive grazing, essential to avoid bush encroachment (Cremene et al., 2005; WallisDeVries et al., 2002). Although highly fragmented, they still harbour many rare and specialized plant and invertebrate species (Steffan-Dewenter and Tscharntke, 2002) and are therefore protected by law in Germany and other European countries (Filz et al., 2013).

\section{Study area}

Our study region around the city of Göttingen (Germany) comprises 285 sharply delimited seminatural calcareous grasslands that differ in size, spatial connectivity, management and successional stage (Krauss et al., 2003b). These grasslands are embedded in an agricultural matrix mainly composed of arable land (42\%) and managed European beech (Fagus sylvatica) forests (37\%) (Krauss et al., 2003a). We conducted our study on 29 calcareous grassland fragments during the spring and summer of 2017 and 2018 (April-September). These fragments were selected in a previous study (Krauss et al., 2003a) along independent (i.e. non-correlated) gradients of habitat area and spatial connectivity.

\section{Landscape metrics}


We characterized the calcareous grasslands at the local (fragment area and fragment spatial connectivity) and landscape levels (percentage of cover types and Shannon diversity of cover types) using the "landscapemetrics" package (Hesselbarth et al., 2019). Fragment size ranged from $82 \mathrm{~m}^{2}$ to $52557 \mathrm{~m}^{2}$, excluding zones dominated by shrubs. The distance between study fragments with respect to the closest neighbouring grassland ranged from $55 \mathrm{~m}$ to $1894 \mathrm{~m}$ (Krauss et al., 2003a). Fragments' spatial connectivity was quantified with a connectivity index developed by (Hanski et al., 1994) and considered all calcareous grasslands in a radius of $2 \mathrm{~km}$ around the study grasslands (see SM for details). Larger values of this index indicate higher spatial connectivity (Table S1). We calculated percentages of land cover types at multiple radii from our focal fragments (i.e. fragment centroids) from $100 \mathrm{~m}$ until $500 \mathrm{~m}$ radius in $50 \mathrm{~m}$ intervals, based on reported spatial scales at which bees and butterflies perceive their environment (Gathmann and Tscharntke, 2002; Steffan-Dewenter and Tscharntke, 2002; Stevens et al., 2013; Westphal et al., 2006). The mapped land cover types were: oilseed rape, grainfield, maize, other crops, forest open, forest closed, field margin, hedgerow, pasture, calcareous grassland, orchard, settlements, water bodies, streets, grassroads and bare soil. We tested the effect of arable land (mainly composed of oil-seed-rape, wheat and maize plantations), seminatural habitat (including calcareous grasslands, orchards, hedgerows, field margins and flower strips) and the Shannon diversity of cover types, on site centrality (see section Statistical analyses). To choose the optimal scales at which these variables had the strongest effects on fragment centrality, we compared linear models at different spatial scales, and chose the scale with the highest predictive value, using the corrected Akaike information criterion for small samples (AICc). Shapefiles of land use were constructed using ArcGis 10.5.1 and all statistics were performed in R (R Development Core Team 2019).

\section{Field data collection}

Each calcareous grassland was visited three times per year in order to capture the succession of flower visitors (hereafter pollinators) and wildflower species throughout the season. We established seven observation plots in each site, totalizing 1218 observations of 10 min each. Surveys were carried out from 9:00 to 17:00 on days with a minimum temperature of $15^{\circ} \mathrm{C}$ and at least $50 \%$ clear sky, or with a minimum temperature of $18{ }^{\circ} \mathrm{C}$ in any sky condition (van Swaay et al., 2012). Sites were surveyed at different times of the day to avoid any potential confounding effect of daytime. 
Observation plots were circular $\left(3 \mathrm{~m}\right.$ radius, $\left.28.3 \mathrm{~m}^{2}\right)$ and were established in flower-rich areas. Within these, all interactions between pollinators (butterflies, Lepidoptera: Papilionoidea; burnet moths, Lepidoptera: Zygaenidae; and bees, Hymenoptera: Apiformes) and flowering plants that occurred in a ten-minute period were registered. A visit by a pollinator was considered to be an interaction as soon as the insect touched the plant reproductive organs. Pollinators not easily recognizable at a distance were captured with a sweep net and photographed or collected for later identification by taxonomists. The timer was paused while handling insects. We excluded interactions involving Apis mellifera as the presence of this species in the region is solely related to the existence of bee keepers in the surroundings. A. mellifera interactions accounted for 1181 from a total of 8114 interactions registered and were present in all sites (range 1-166 A. mellifera interactions per site).

\section{Plant-pollinator traits}

Plants and pollinators were classified according to their life-history traits. Habitat specialization followed Piqueray et al. (2011) for plants, Jauker et al. (2013) and Hopfenmüller et al. (2014) for bees, and van Swaay (2002) and Brückmann et al. (2010) for butterflies. Body length values for bees were taken from Westrich (2018) and wing length values for butterflies were taken from Sterry and Mackay (2004). All values were standardized to make them comparable by subtracting the mean and dividing by the standard deviation of each group. Butterflies were considered large whenever their wing length was equal or larger than $16 \mathrm{~mm}$ (median wing length of butterflies), otherwise they were classified as small. On the other hand, bees were considered large when having a body length of $10 \mathrm{~mm}$ or more (median body length of bees) and were otherwise considered small (Fig. S2).

\section{Metanetwork structure}

A metanetwork was built by pooling the 29 calcareous grasslands into an aij adjacency matrix, in which $i$ are the studied sites and $j$ the pairwise plant-pollinator interactions. First, we characterized the overall structure by calculating: (1) pollinator richness, plant richness and plantpollinator interaction richness; (2) connectance: here defined as the realized proportion of plantpollinator interactions per fragment regarding all possible interactions at the metanetwork level (Dunne et al., 2002); (3) modularity: here, the organization in sub-groups of fragments and 
interactions that are highly connected among themselves but less with other sub-groups; estimated using the DIRTLPAwb+ algorithm (Beckett, 2016).

Second, we estimated the centrality (Freeman, 1978; González et al., 2010) of the metanetwork nodes by calculating: (4) interaction degree, as the number of fragments in which a given interaction occurs; (5) interaction weighted degree, as the frequency of an interaction across all fragments; (6) fragment degree, as the number of unique pairwise interactions that a given fragment holds (i.e. interaction richness per site); (7) fragment weighted degree, as the frequency of interactions that a given fragment holds (i.e. interaction frequency per site).

All network metrics were calculated using the "bipartite" package in R (Dormann et al., 2008).

\section{Statistical analyses}

First, we assessed the significance of the metanetwork connectance and modularity against independent null models that constrain network size while randomizing the distribution of links among rows and columns, but holding the marginal totals constant (Dormann et al., 2009). That is, fragments maintain the same number of interactions in the null models, and interactions maintain the same number of fragments in which they occur. We obtained the mean and standard deviation of 100 iterations of each null model to test against the observed values of each corresponding metric (i.e. obtaining their z-scores). In a post hoc analysis we used linear and generalized linear models to explore local (fragment area and connectivity) and landscape (diversity of cover types) level effects on the number and proportion of single-fragment interactions per fragment.

Second, we tested whether species traits affected the centrality of plant-pollinator interactions (i.e. interaction degree and interaction weighted degree) using generalized linear mixed models. Specifically, we tested for the effects of the plant and pollinator habitat specialization, as well as pollinator size and guild (i.e. bumblebee, solitary bee or butterfly), on the centrality of the interactions they perform. Our full models included the mentioned explanatory variables, all their two-way interactions, the plants' and animals' active period regarding season (categorical with three levels: Spring, Summer or Spring and Summer) and number of months active. Furthermore, we included plant's and animal's identity as crossed random intercepts. 
Finally, we tested whether the previously described fragment and landscape traits affected the centrality of the calcareous grassland fragments. Specifically, we tested the effects of $(\log )$ fragment area, (log) connectivity index and the Shannon index of cover types (hereafter, landscape diversity). Percentage of semi-natural habitat was excluded from the analyses as it was correlated with fragment area (Pearson's corr $=0.66, \mathrm{P}<0.001)$ and with landscape diversity (Pearson's corr $=0.51, \mathrm{P}=0.004)$.

We used a truncated negative binomial distribution and the "glmmTMB" package in all centrality models (Magnusson et al., 2017). We selected the minimum adequate models using backwards model selection with likelihood ratio tests. All non-significant explanatory variables $(\mathrm{P}>0.05)$ were sequentially removed. Post-hoc tests were performed with the "lsmeans" package (Lenth, 2017). All network and statistical analyses were performed in R (R Development Core Team 2019).

\section{Results}

\section{Metanetwork structure}

The metanetwork had a total of 6936 plant-pollinator interaction events from a pool of 842 unique pairwise plant-pollinator combinations among 131 plant species and 118 pollinator species on 29 calcareous grassland fragments (Fig. 1). From those, 4722 (68.1\%) plant-pollinator interactions occurred among 46 butterfly species and 99 plant species, comprising a total of 474 unique pairwise plant-butterfly interactions (56.3\%). On the bees' side, we found 12 bumblebee species interacting 1891 (27.3\%) times with 89 plant species, totalizing 214 unique pairwise plant-bumblebee interactions (25.4\%). In addition, we found 320 (4.6\%) interactions among 60 solitary bee species and 50 plant species, involving 154 unique pairwise plant-bee interactions (18.3\%). On average, each fragment comprised $28.2 \pm 6.7$ (mean \pm s.d.) pollinator species, $22.3 \pm$ 5.2 plant species and $71.5 \pm 21.7$ unique pairwise interactions.

Overall, the metanetwork was significantly less connected $(\mathrm{C}=0.08, \mathrm{P}<0.001)$ and more modular $(\mathrm{M}=0.39, \mathrm{P}<0.001)$ than expected from null models (Fig. S1). The modular structure was organized around 17 modules, with an average of 1.7 fragments and 49.5 unique interactions per module. 
a)

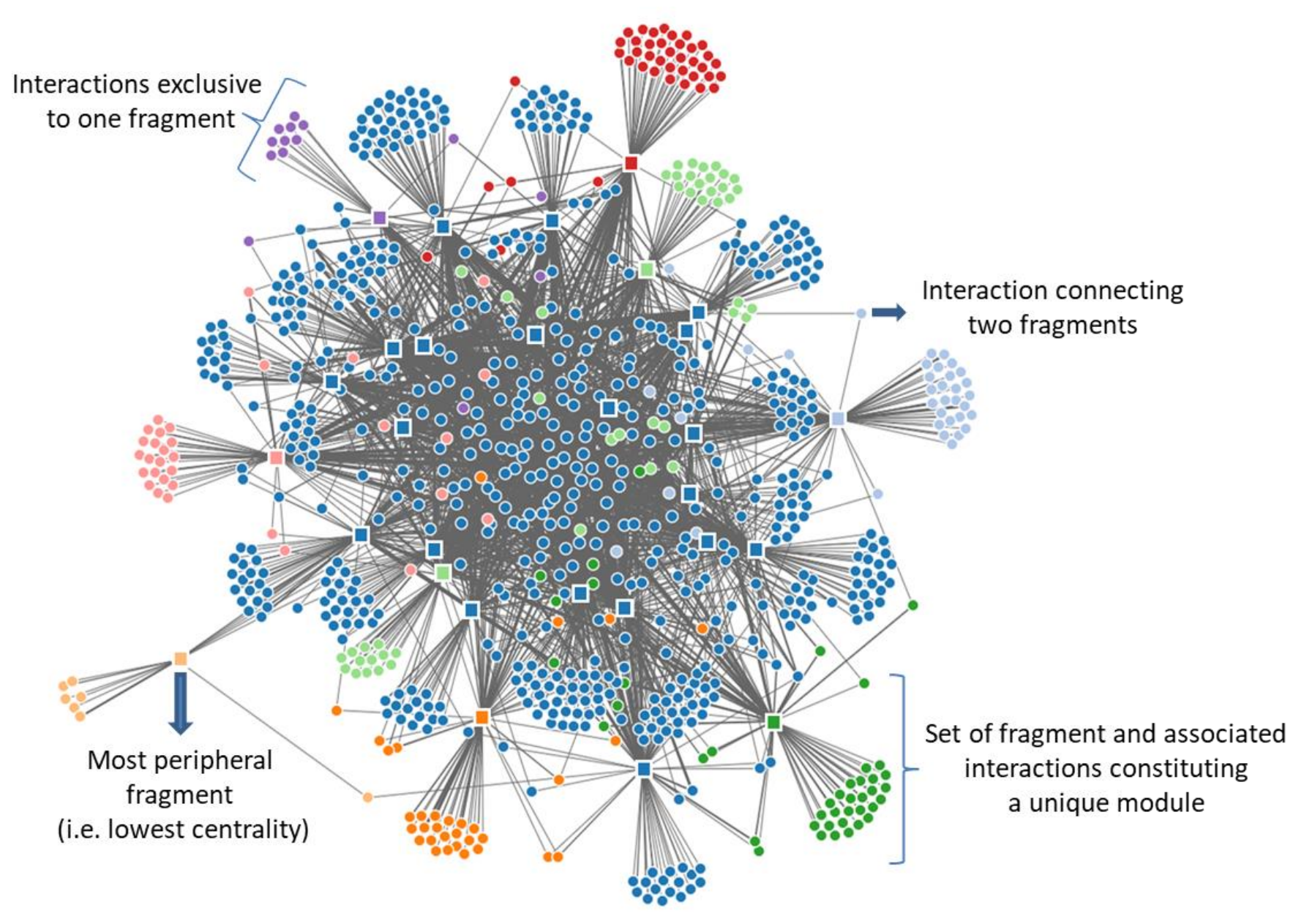


b)

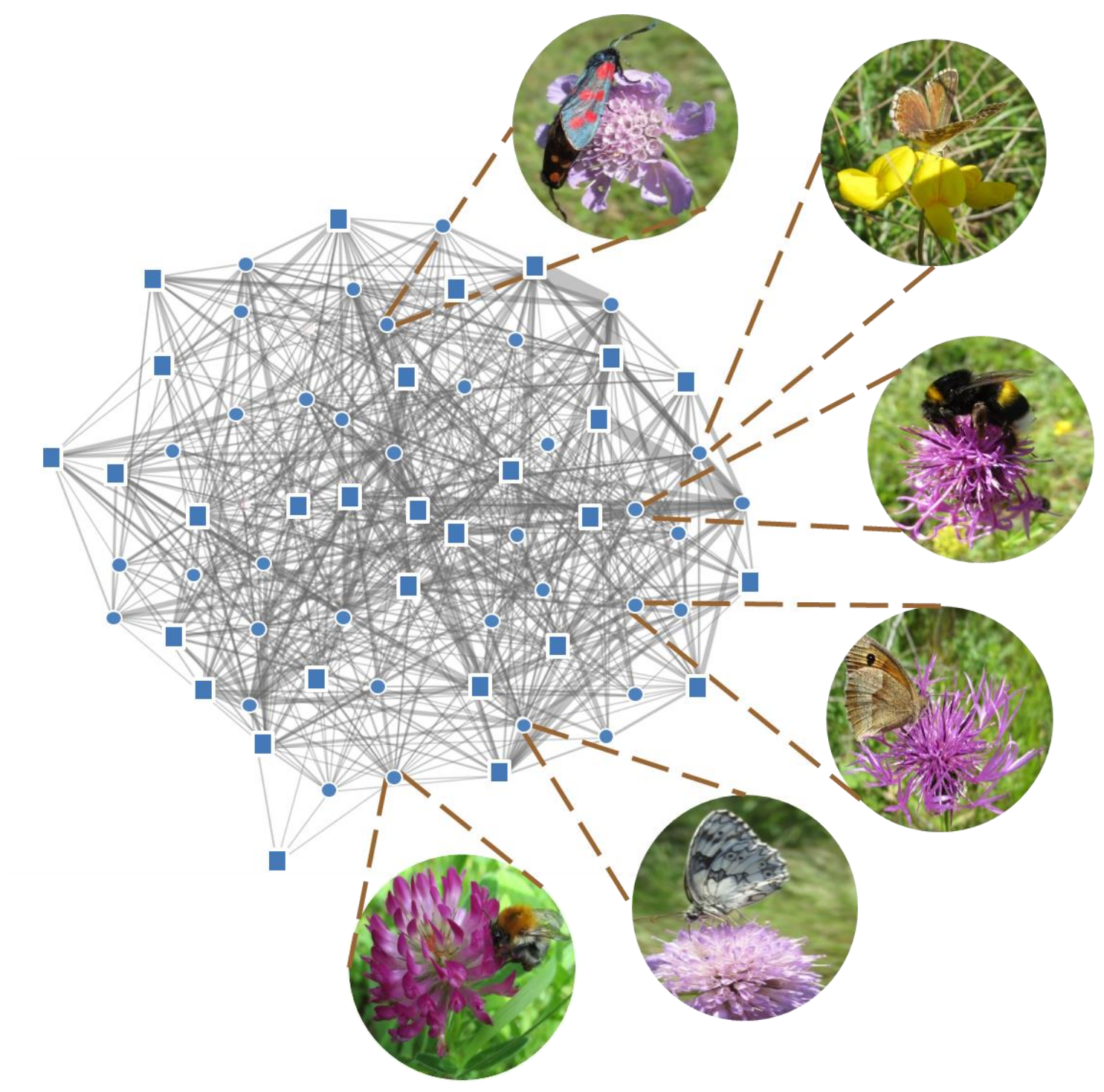

Figure 1. a) The plant-pollinator metanetwork structure of the calcareous grassland fragments. Circles indicate unique pairwise combinations of plant and pollinator species that perform pollination interactions $(\mathrm{n}=842)$ and squares represent the studied sites $(\mathrm{n}=29)$. Interactions occurring in at least two sites form links connecting them. The thickness of links (gray lines) is proportional to interaction frequency (range 1-254). Colors represent metanetwork modules based on the Walktrap community-finding algorithm (igraph package). This algorithm indicates the presence of sub-graphs that constitute a distinctive community. Nodes with greater centrality occur in the central positions of the graph based on the "gravitational force" on degree (Bannister et al., 2013). b) Sub-graph of the metanetwork, zooming on the core plant-pollinator interactions (here those present in more than 10 sites). 


\section{Single-fragment interactions}

Only $305(36.2 \%)$ unique pairwise plant-pollinator interactions occurred in at least two fragments, but these made up for the majority of observed plant-pollinator interactions (6171, or $89 \%$ ). This means that more than half of the unique plant-pollinator combinations were rare and local (i.e., occurred in a single fragment). Landscape diversity had a positive effect on the number of single-fragment plant-pollinator interactions $\left(X^{2}=12.25, P<0.001\right.$, Fig. 2a) and a negative effect on the proportion single-fragment interactions respect to all unique interactions in a certain fragment $(F=8.08, P=0.008$, Fig. $2 b)$. Fragment area and fragment connectivity did not have significant effects on the number of single-fragment interactions or their proportion respect to all interactions (Table S3).

a)

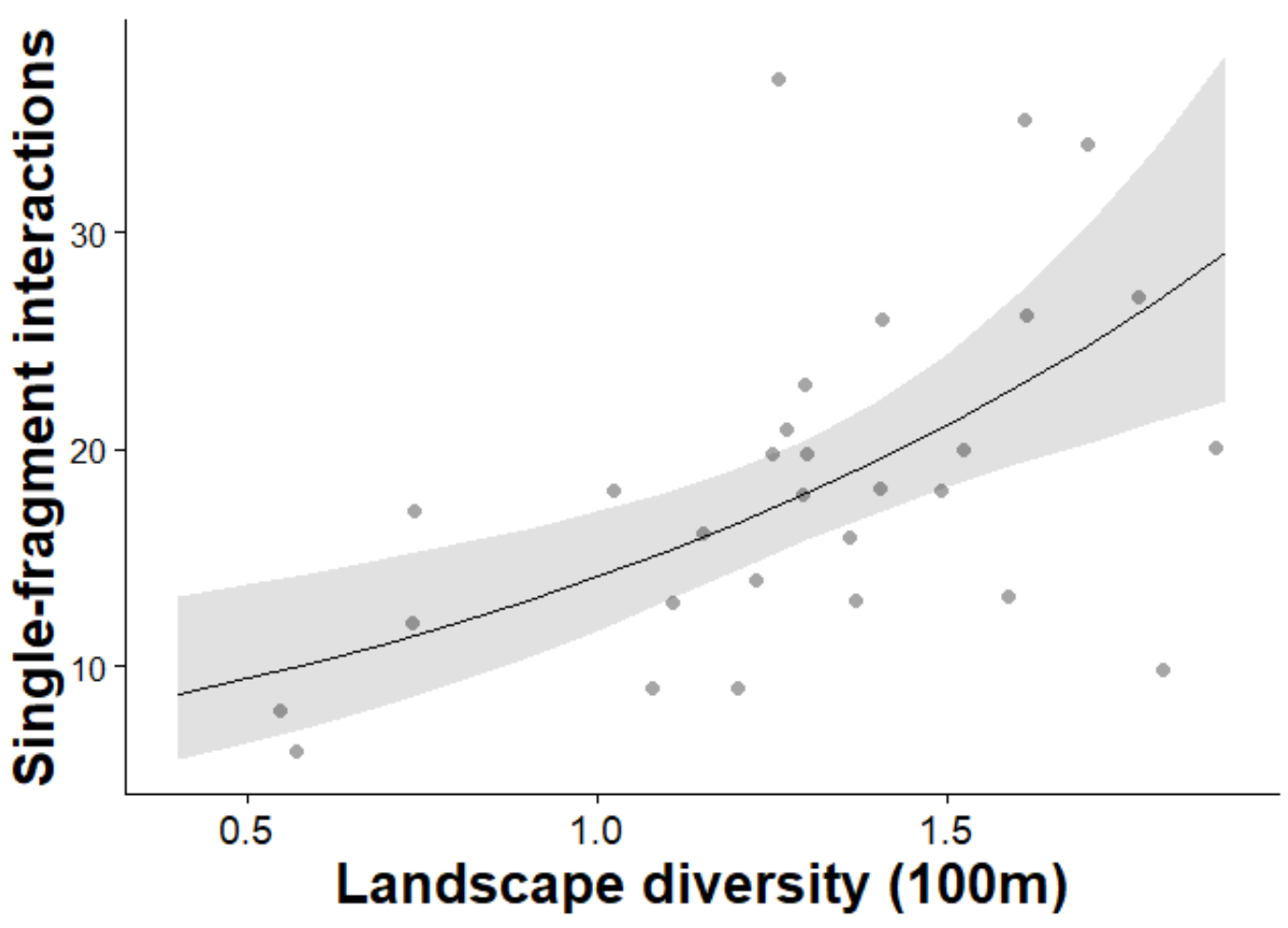


b)

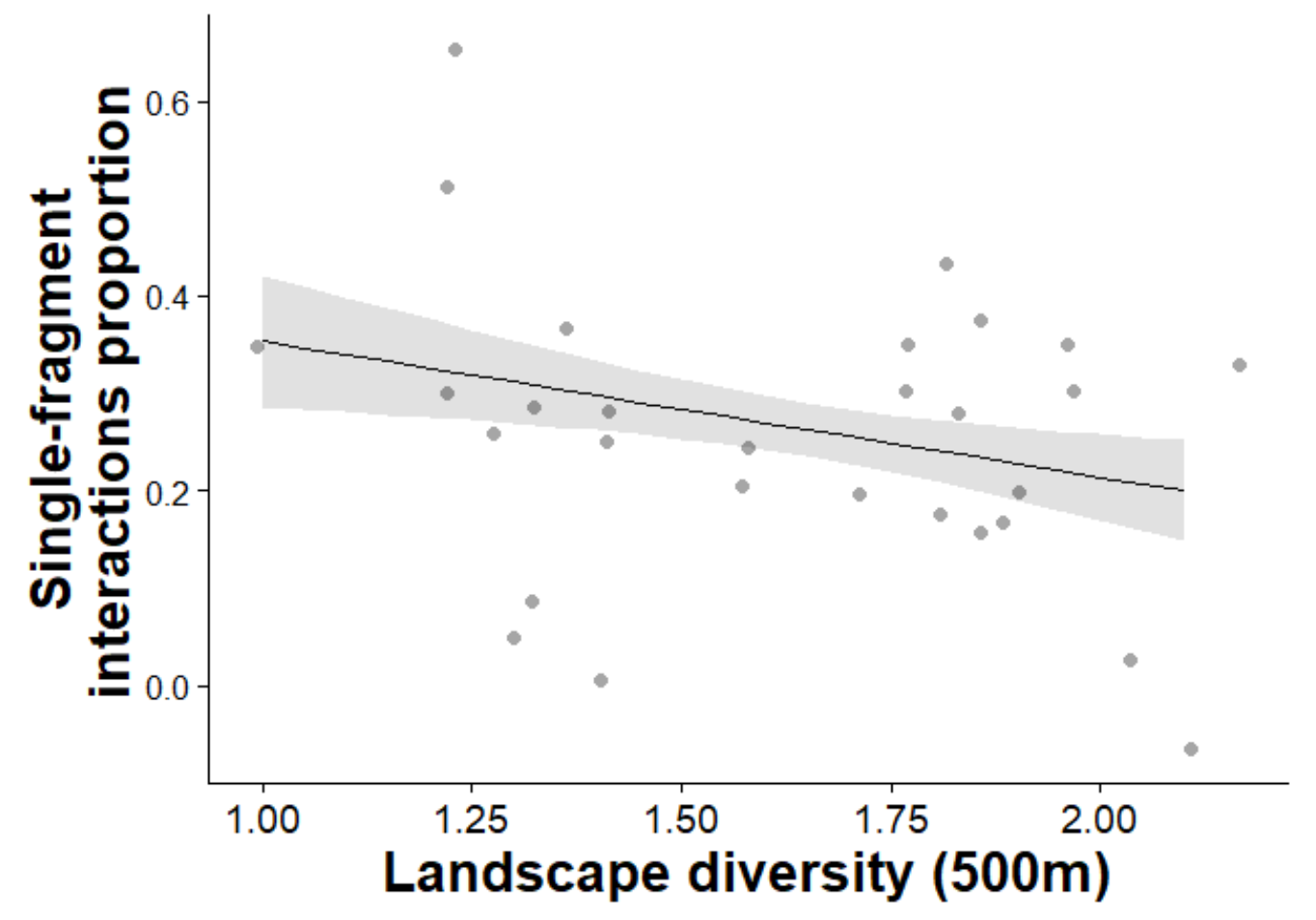

Figure 2. Relationship between a) the number of single-fragment interactions (i.e. those that occur in only one fragment from the 29 fragments studied) and b) the proportion of single-fragment interactions, with landscape diversity. The proportion is the number of single-fragment interactions divided by interaction richness in a specific fragment.

\section{Interaction centrality and biological traits}

Plant habitat specialization was a significant predictor of interaction degree $\left(X^{2}=12.78, P<\right.$ 0.001, Table S2). Specifically, interactions involving habitat specialist plants had significantly higher degree than those involving habitat generalist plants (Fig. 3a). Additionally, pollinator identity and the interaction between plant habitat specialization and pollinator size were found to be significant predictors of interaction weighted degree (Table S2). Specifically, interactions involving habitat specialist plants and large-bodied pollinators had higher weighted degree than those involving habitat generalist plants and small-bodied pollinators $\left(X^{2}=5.28, P=0.021\right.$, Fig. $3 b)$. Moreover, interactions performed by butterflies $(t=-2.50, P=0.034)$ and bumblebees $(t=-$ $2.75, \mathrm{P}=0.016$ ) had higher weighted degree than those performed by solitary bees (Fig. 3b). 


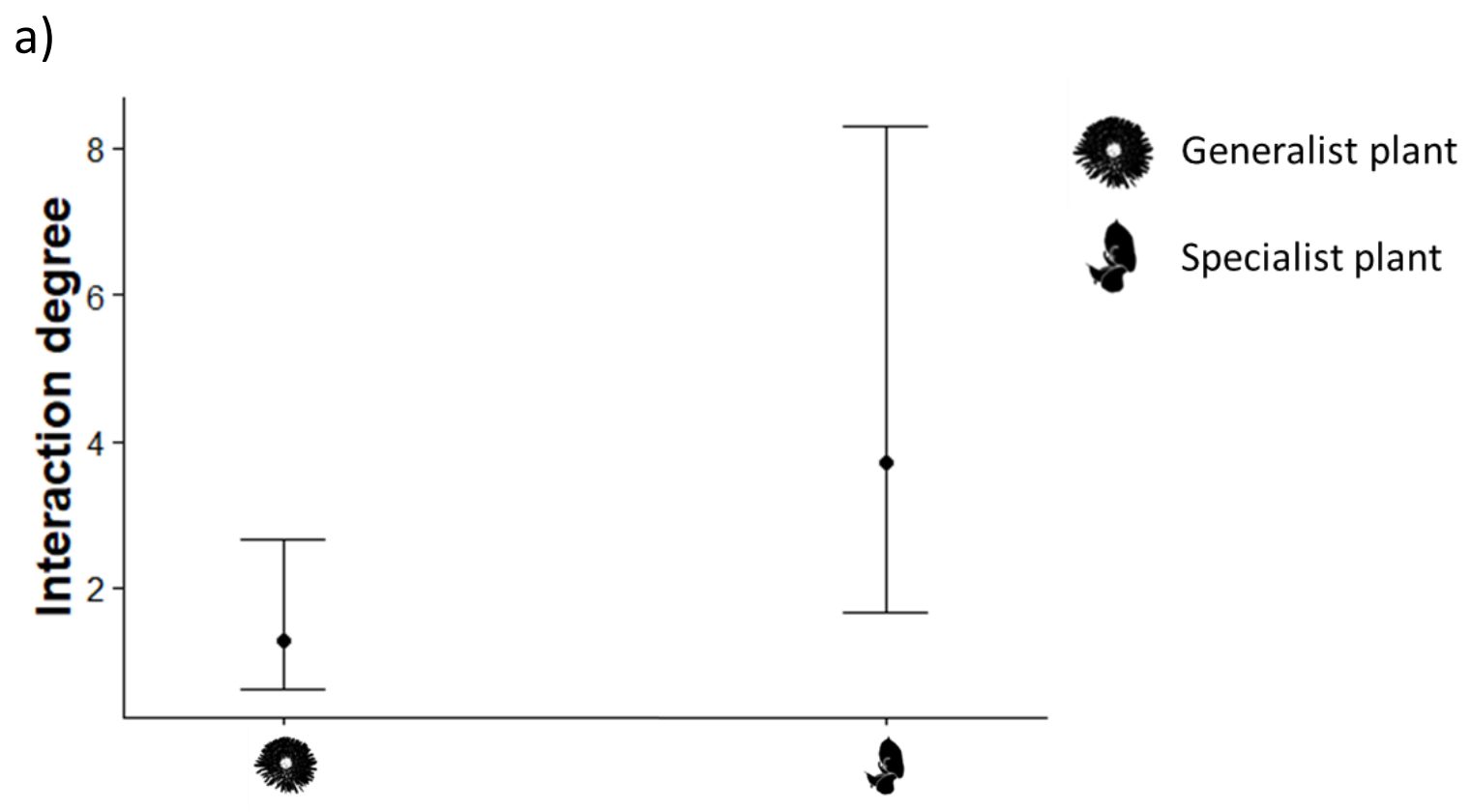

b)

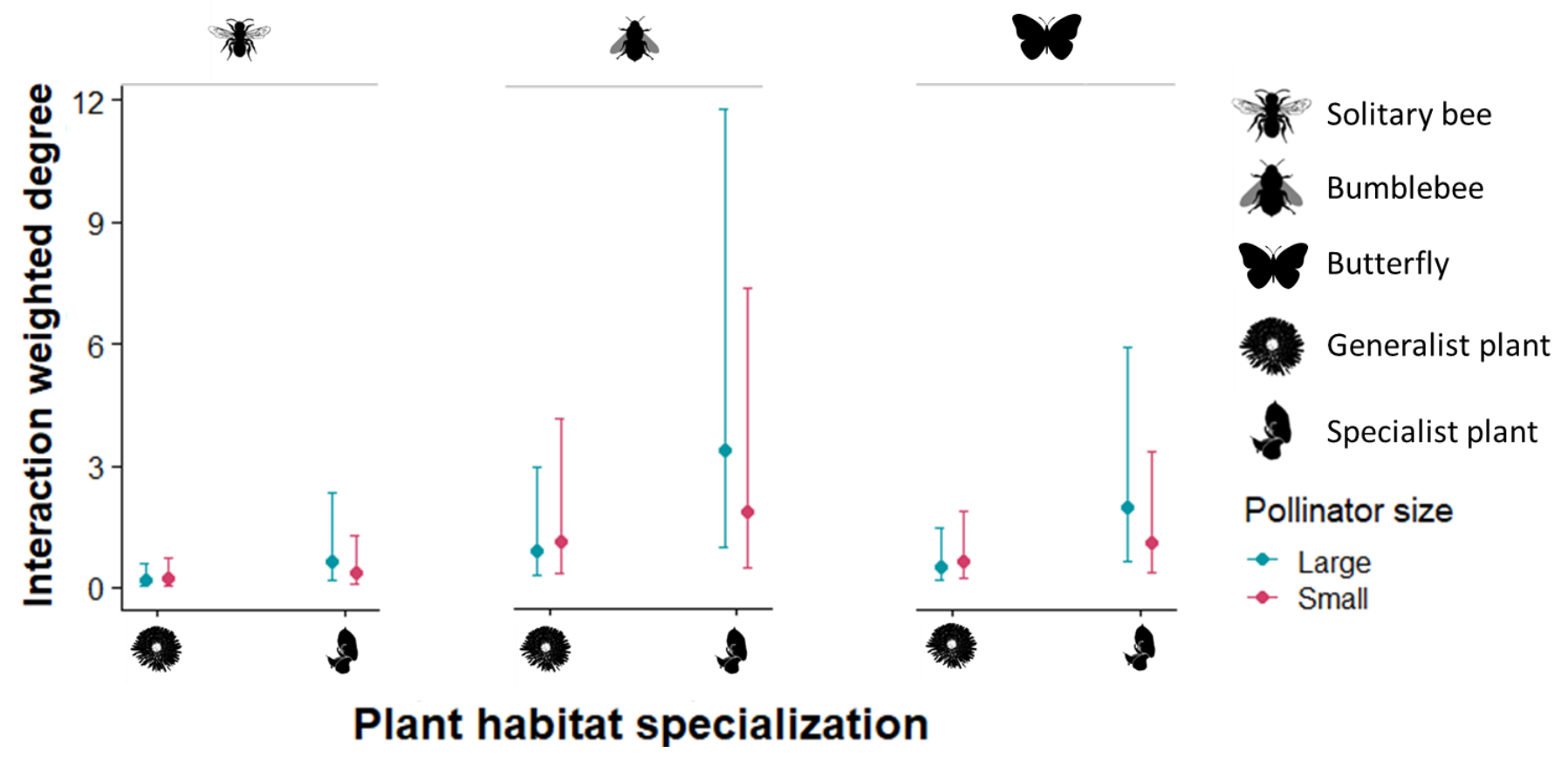

Figure 3. Relationship between a) interaction degree (i.e. number of fragments on which a specific plantpollinator interaction pair occurs) with plant habitat specialization and b) interaction weighted degree (i.e. interaction frequency across all fragments) with plant habitat specialization, pollinator size and pollinator identity. Bars represent $95 \%$ confidence intervals.

Fragment centrality and landscape features 
Larger calcareous grassland fragments were more central in the metanetwork, as indicated by the positive effect of fragment area on fragment degree $\left(\mathrm{X}^{2}=4.24, \mathrm{P}=0.04\right)$ and fragment weighted degree $\left(\mathrm{X}^{2}=11.40, \mathrm{P}<0.001\right.$, Fig. 4). In addition, landscape diversity had also a positive effect on fragment centrality as evidenced by increased fragment degree $\left(\mathrm{X}^{2}=4.67, \mathrm{P}<0.001\right)$ and weighted degree $\left(\mathrm{X}^{2}=12.54, \mathrm{P}<0.001\right)$. Conversely, fragment connectivity and arable land had no significant effects on fragment degree $\left(\mathrm{X}^{2}=0.95, \mathrm{P}=0.33 ; \mathrm{X}^{2}=1.27, \mathrm{P}=0.26\right.$ ) nor on fragment weighted degree $\left(\mathrm{X}^{2}=0.013, \mathrm{P}=0.91 ; \mathrm{X}^{2}=2.37, \mathrm{P}=0.12\right)$.

a)

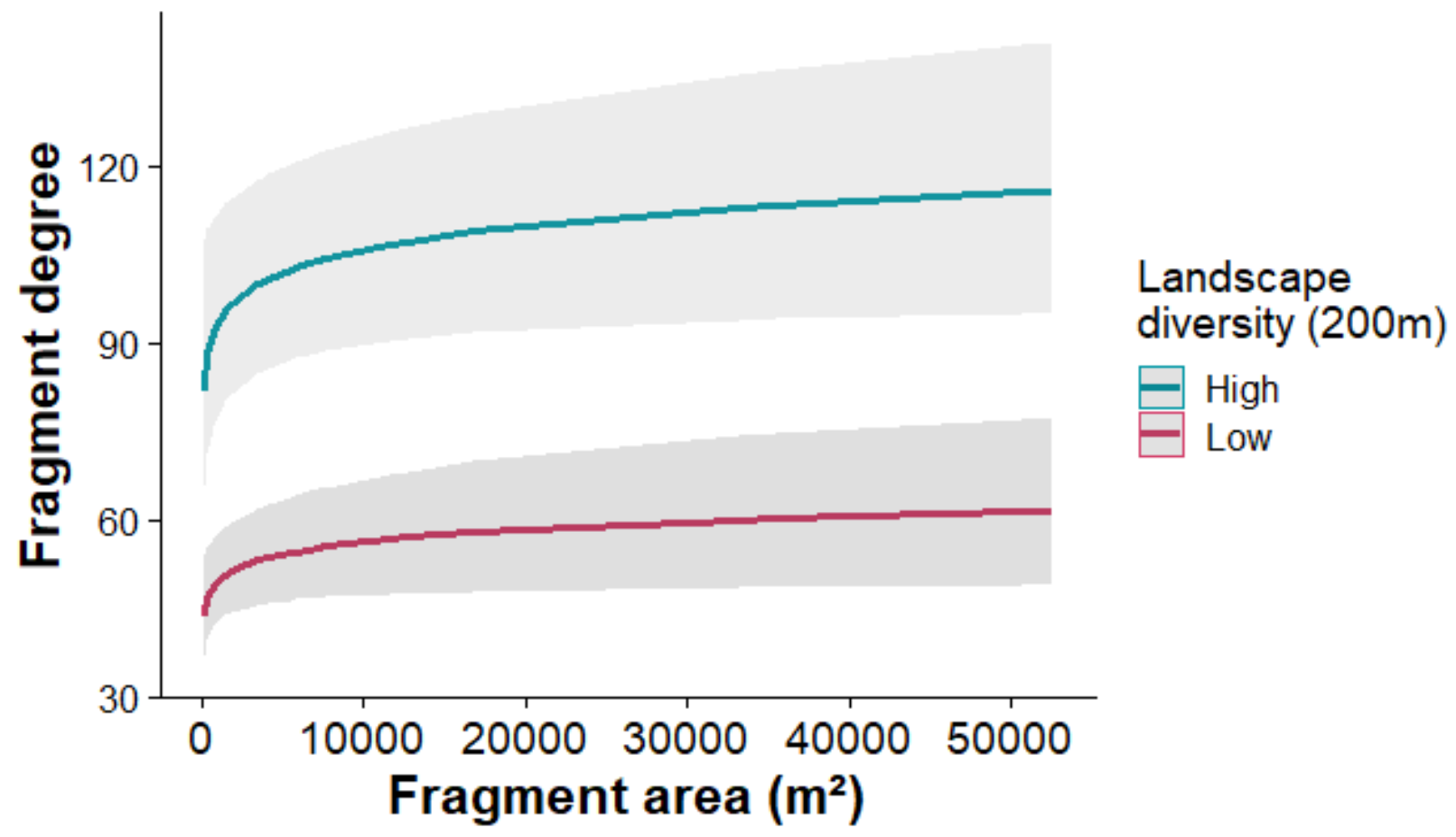


b)

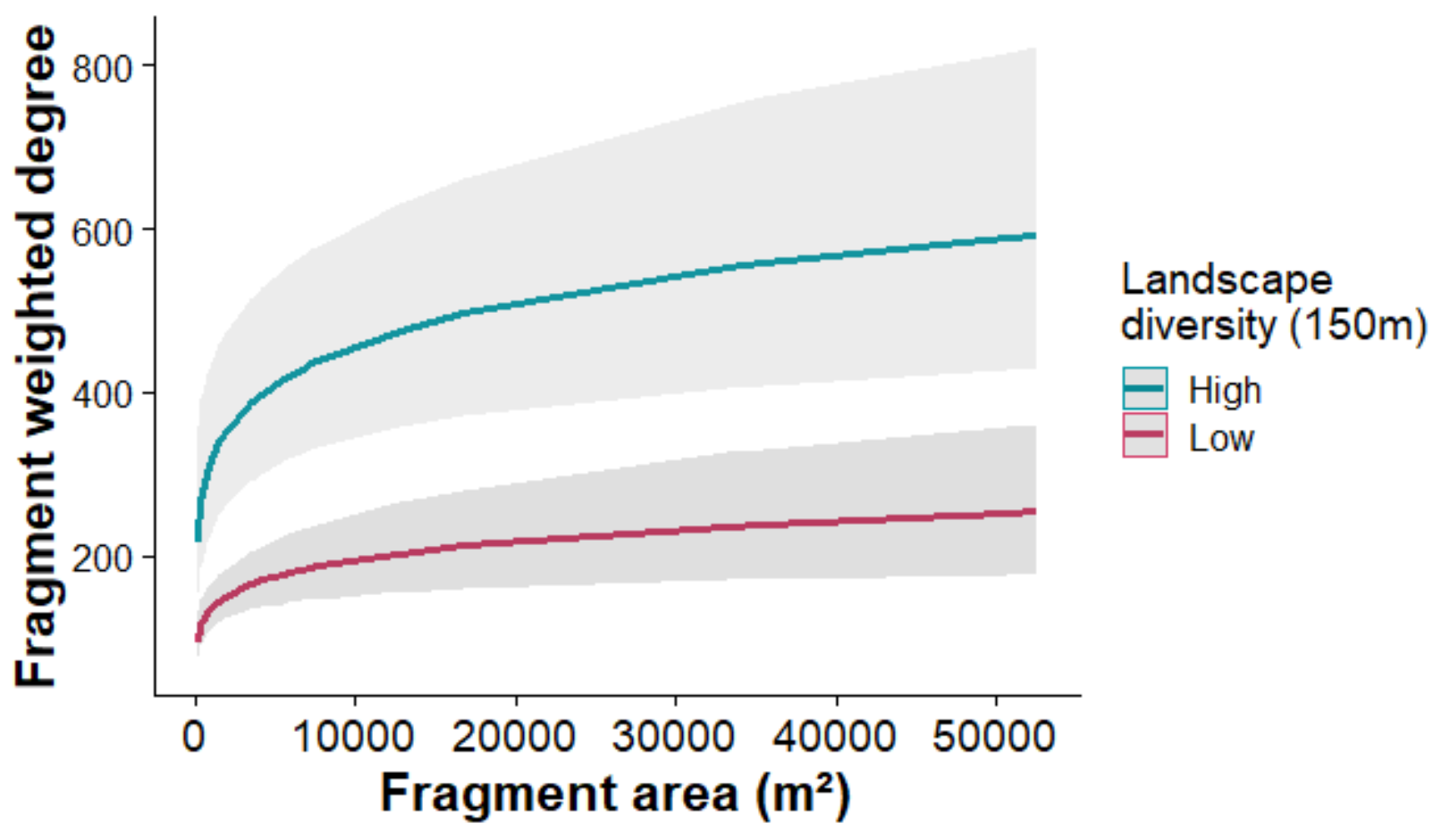

Figure 4. Effects of calcareous grassland fragment size and landscape diversity (here calculated as the Shannon diversity index of cover types) on a) interaction richness and b) interaction frequency. Grey areas represent $95 \%$ confidence intervals.

\section{Discussion}

Here we analyzed a plant-pollinator metanetwork along a habitat fragmentation gradient over a two-years period. We found that plant-pollinator interactions involving habitat specialist plants and large-bodied pollinators were the most central in our system. Bumblebees and butterflies established more central interactions than solitary bees. Moreover, large fragments embedded in landscapes with high land cover diversity exhibited the highest centrality, while small fragments harbored a high share of unique interactions not found on larger fragments.

\section{Plant-pollinator metanetwork structure}

As predicted, the plant-pollinator metanetwork was more modular and less connected than expected by chance. The different modules within the metanetwork appear to reflect the presence of unique pools of interacting species in different fragments of calcareous grassland where local species tend to establish specific associations among each other. Interestingly, compared to the 
only previous study applying the same methodology, a plant-frugivore metanetwork in the Brazilian Atlantic Forest (Emer et al., 2018), our plant-pollinator metanetwork was less modular. This might be explained by two reasons, namely the difference in the biology of the systems and the difference in scale. The extent of the study region and the size of the fragments were smaller in our study. This is related to the larger size of the Brazilian Atlantic Forest fragments compared to the calcareous grasslands fragments in our region (Ribeiro et al., 2009). Considering that some large-bodied pollinator species should be able to actually cross the matrix and reach some of the nearest neighboring grasslands in our system (Steffan-Dewenter and Tscharntke, 1999), the present study constitutes a more applied version of the metanetwork concept than in the case of (Emer et al., 2018), where the chance of a bird reaching a neighboring studied fragment was small (minimum distance among studied fragments was $26 \mathrm{~km}$ ). The pollinators recorded in our study may thus act as mobile links among fragments reducing modularity, which is supported by the strong core of central interactions in our metanetwork (Fig. 1b).

Network theory predicts that modularity can reduce the sensitivity of interconnected systems to perturbations as these will not easily spread to the whole network (Dormann et al., 2017). However, modularity has also been associated to reduced stability in mutualistic networks (Thébault and Fontaine, 2010). A highly modular network depends on the presence of connector species (i.e. species establishing interactions across modules) to maintain its integrity and prevent it from breaking apart into separate modules. Once modules are disconnected, they become smaller independent networks on their own and consequently become more prone to collapse given their smaller size and higher sensitivity to stochastic events (Traveset et al., 2017; Tscharntke et al., 2002).

As established by (Olesen et al., 2007), only a small proportion of species are structurally important to a network, however, when these are lost, cascades of extinctions might occur, leading to a general collapse of the network. In our case, the species involved in the interactions showed in Figure $1 \mathrm{~b}$ are the most important to the metanetwork, as they are the key connections among otherwise segregated modules. Interestingly, all pollinator species involved in the most central interactions of our system were habitat generalists (except for Polyommatus coridon), but most plant species were habitat specialists, i.e. characteristic species of the studied calcareous grasslands. This means that in addition to protecting habitat specialist species of calcareous grasslands by targeted management strategies (Filz et al., 2013), biodiversity-friendly measures 
in the matrix, such as flower strips, hedgerows and crop diversification, could help to protect central pollinators acting as mobile links (Kleijn et al., 2006; Sirami et al., 2019). Protecting habitat generalist pollinators, in turn, maintains the cohesiveness of the metanetwork, thereby also protecting habitat specialist plant species (directly) and habitat specialist pollinator species (indirectly). In other words, conservation measures aiming at this core group of generalist species may indirectly help to conserve also specialist species. Furthermore, protecting Polyommatus coridon might also be possible by including Hippocrepis comosa into seed mixtures of agrienvironmental schemes (Batáry et al., 2015), as it is its solely larval food plant in western Europe (Schmitt, 2015).

\section{Unique pairwise plant-pollinator interactions}

All unique pairwise interactions, including single-fragment interactions, increased with landscape diversity (Fig. 2a and Fig. 4a), but the proportion of single-fragment interactions decreased with it (Fig. 2b), i.e. the rate at which all unique pairwise interactions increase with landscape diversity is higher than that of single-fragment interactions. This result may be related to the high amount of interactions established by large-bodied habitat generalist butterflies. As a consequence of their high mobility, these butterflies are expected to connect the metanetwork by reaching multiple calcareous grassland fragments. Hence, differently from bees, that are spatially attached to their nests, the majority of the interactions established by large-bodied habitat generalist butterflies may not be restricted to a single fragment.

\section{Interaction centrality and species traits}

Our results show that interactions between habitat specialist plants and pollinators are fundamental to the metanetwork (Fig. 3). Despite representing only $17.6 \%$ of the plant species found and despite being involved in only $38.9 \%$ of all unique pairwise interactions, interactions conformed by habitat specialist plants and pollinators were more central than those involving habitat generalist plants. Hence, habitat specialist plants in calcareous grasslands establish interactions that provide cohesiveness and stability to the metanetwork, highlighting the importance of their conservation. Contrastingly, although habitat generalist plants establish numerous interactions, those interactions do not belong to the core interactions of the plantpollinator metacommunity in calcareous grasslands. A notable exception is the habitat generalist plant Knautia arvensis, which established many central interactions particularly with large- 
bodied butterflies. Whether this is a consequence of interaction rewiring due to the absence of the related habitat specialist Scabiosa columbaria remains to be studied.

As expected, large-bodied pollinators established more central interactions than small-bodied ones. Movement capacity is positively correlated to body size (Stevens et al., 2014). Large pollinators have larger foraging ranges (Greenleaf et al., 2007), which may allow them to reach a higher amount of calcareous grassland fragments, increasing the number of plant species available with which they can potentially interact. From the plant species perspective, it is reasonable for habitat specialist plants to specialize more on large-bodied pollinators that are not constrained to the focal fragment and can eventually disperse their pollen at greater distances. This assumption is supported by our finding that the core of the most central interactions is in fact formed by habitat specialist plants and large-bodied pollinators (Fig. 1b and Fig. 3b). Whether this pattern is a consequence of habitat fragmentation or a characteristic feature of calcareous grasslands needs to be further explored, for example, by analyzing plant-pollinator interactions exclusively in large continuous calcareous grasslands.

Solitary bees were found to be involved in interactions of lower centrality than those of butterflies and bumblebees. In comparison to social bees, such as bumblebees, solitary bees typically have much more restricted movement capacity (Gathmann and Tscharntke, 2002; Westphal et al., 2006). Also, bumblebees establish numerous interactions with both specialist and generalist plants given their high abundance favored by their social life in colonies (Hass et al., 2019; Leidenfrost et al., 2020). Nonetheless, all bees are somehow attached to the nest position to which they need to come back regularly, independent of whether they are social or solitary species. Butterflies, on the other hand, are not attached to a nest and therefore can potentially move longer distances than bees throughout their lives. In particular, this may be the case for large-bodied generalist butterflies, as small specialist butterflies have a much smaller capacity and probability to cross the matrix and reach other fragments (Habel et al., 2020).

\section{Fragment centrality and landscape traits}

As expected, habitat fragment size had a positive effect on fragment degree and on fragment weighted degree (Fig. 4). This result is not surprising given that larger fragments tend to harbor larger species populations and consequently have a higher probability of interaction

establishment. Although larger fragments might favor the presence of area-sensitive, 
monophagous and rare specialist species (Rösch et al., 2015; Steffan-Dewenter and Tscharntke, 2002), it has been demonstrated that in a fragmented landscape many small fragments harbor a larger amount of habitat specialist species than a single large fragment of the same area (Rösch et al., 2015; Tscharntke et al., 2002). Given the high amount of unique interactions involving habitat specialist species that were restricted to small fragments, a similar importance of small fragments seems to hold for species interactions. Therefore, it needs to be highlighted that although large fragments are fundamental for the metanetwork stability and cohesiveness, small fragments contribute many unique pairwise interactions that cannot be conserved by only focusing on large fragments.

Interestingly, fragments embedded in landscape with high land cover diversity exhibited higher fragment centrality, meaning that these fragments had higher numbers of unique and total plantpollinator interactions. This finding has important implications for conservation as it highlights the essential role of not only protected habitats, but also the surrounding landscape to protect plant-pollinator interactions. A diverse landscape multiplies the number of resources available for pollinators, such as nectar, pollen and nesting opportunities, and therefore contributes to their persistence in the landscape (Landis et al., 2005). Furthermore, the presence of linear elements such as flower strips and hedgerows can facilitate animal movement through the landscape and between fragments (Davies and Pullin, 2007; Holzschuh et al., 2009; Klaus et al., 2015; van Geert et al., 2010). The ability of large-bodied specialist butterflies, such as Polyommatus coridon, to cross the matrix and reach surrounding calcareous grasslands needs to be further explored. However, some studies have found that a small proportion of individuals of this species can cross matrix gaps of a few hundred meters and exceptionally a few kilometers (Schmitt et al., 2006; Schmitt, 2015). The protection of this particular butterfly species and the interactions it establishes appears fundamental for the integrity of the metanetwork system.

\section{Conclusion}

We analyzed a plant-pollinator metanetwork along a habitat fragmentation gradient over a twoyear period. We identified the most central plant-pollinator interactions and habitat fragments in the metanetwork and traits associated to their centrality. We found that plant-pollinator interactions involving habitat specialist plants and large-bodied pollinators were the most central and thus structurally important in our system. Furthermore, bumblebees and butterflies established more central interactions than solitary bees, highlighting the importance of social bees 
and mobile butterflies for maintaining plant-pollinator interactions in fragmented landscapes. Importantly, large fragments embedded in landscapes with high land cover diversity exhibited the highest centrality. Conserving large grasslands fragments and diversifying the agricultural matrix is thus fundamental for the cohesiveness and stability of plant-pollinator metanetworks. In particular, crop diversification and conservation schemes such as agri-environmental schemes may promote metanetwork stability. However, although large fragments were the most central in our system, small fragments also need protection as they harbor a high proportion of unique interactions not found in large fragments.

\section{Acknowledgments}

This research was supported by the German Research Association (DFG) Research Training Group 1644 "Scaling Problems in Statistics", grant no. 152112243. We thank all friends, student helpers and fieldwork assistants that contributed to data collection.

\section{References}

Bascompte J, Jordano P, Melian CJ, Olesen JM. The nested assembly of plant-animal mutualistic networks. Proceedings of the National Academy of Sciences of the United States of America 2003;100(16):9383-7.

Batáry P, Dicks LV, Kleijn D, Sutherland WJ. The role of agri-environment schemes in conservation and environmental management. Conservation biology the journal of the Society for Conservation Biology 2015;29(4):1006-16.

Beckett SJ. Improved community detection in weighted bipartite networks. Royal Society open science 2016;3(1):140536.

Boesing AL, Nichols E, Metzger JP. Biodiversity extinction thresholds are modulated by matrix type. ECOGRAPHY 2018;41(9):1520-33.

Brückmann SV, Krauss J, Steffan-Dewenter I. Butterfly and plant specialists suffer from reduced connectivity in fragmented landscapes. Journal of Applied Ecology 2010;47(4):799-809.

Burkle LA, Marlin JC, Knight TM. Plant-pollinator interactions over 120 years: loss of species, co-occurrence, and function. Science (New York, N.Y.) 2013;339(6127):1611-5.

Cremene C, Groza G, Rakosy L, Schileyko AA, Baur A, Erhardt A et al. Alterations of steppelike grasslands in Eastern Europe: a threat to regional biodiversity hotspots. Conservation Biology 2005;19(5):1606-18. 
Davies ZG, Pullin AS. Are hedgerows effective corridors between fragments of woodland habitat? An evidence-based approach. Landscape Ecol 2007;22(3):333-51.

Delmas E, Besson M, Brice M-H, Burkle LA, Dalla Riva GV, Fortin M-J et al. Analysing ecological networks of species interactions. Biological Reviews 2019;94(1):16-36.

Dormann CF, Fruend J, Martin Schaefer H. Identifying Causes of Patterns in Ecological Networks: Opportunities and Limitations. Annual Review of Ecology, Evolution and Systematics, VOL 48 2017;48:559-84.

Dormann CF, Fründ J, Blüthgen N, Gruber B. Indices, graphs and null models: analyzing bipartite ecological networks. The Open Ecology Journal 2009;2(1).

Dormann CF, Gruber B, Fründ J. Introducing the bipartite package: analysing ecological networks. interaction 2008;1(0.2413793).

Dunne JA, Williams RJ, Martinez ND. Food-web structure and network theory: The role of connectance and size. Proceedings of the National Academy of Sciences of the United States of America 2002;99(20):12917-22.

Emer C, Galetti M, Pizo MA, Guimarães PR, Moraes S, Piratelli A et al. Seed-dispersal interactions in fragmented landscapes - a metanetwork approach. Ecology letters 2018;21(4):484-93.

Estrada E. Characterization of topological keystone species: local, global and "meso-scale" centralities in food webs. Ecological Complexity 2007;4(1-2):48-57.

Fahrig L. Non-optimal animal movement in human-altered landscapes. Funct Ecol 2007;21(6):1003-15.

Ferreira PA, Boscolo D, Viana BF. What do we know about the effects of landscape changes on plant-pollinator interaction networks? Ecological Indicators 2013;31:35-40.

Filz KJ, Engler JO, Stoffels J, Weitzel M, Schmitt T. Missing the target? A critical view on butterfly conservation efforts on calcareous grasslands in south-western Germany. Biodivers Conserv 2013;22(10):2223-41.

Freeman LC. Centrality in social networks conceptual clarification. Social networks 1978;1(3):215-39.

Galetti M, Guevara R, Côrtes MC, Fadini R, Matter S von, Leite AB et al. Functional extinction of birds drives rapid evolutionary changes in seed size. Science (New York, N.Y.) 2013;340(6136):1086-90.

Gathmann A, Tscharntke T. Foraging ranges of solitary bees. Journal of Animal Ecology 2002;71(5):757-64. 
González AMM, Dalsgaard B, Olesen JM. Centrality measures and the importance of generalist species in pollination networks. Ecological Complexity 2010;7(1):36-43.

Grass I, Jauker B, Steffan-Dewenter I, Tscharntke T, Jauker F. Past and potential future effects of habitat fragmentation on structure and stability of plant-pollinator and host-parasitoid networks. Nature Ecology \& Evolution 2018;2(9):1408-17.

Greenleaf SS, Williams NM, Winfree R, Kremen C. Bee foraging ranges and their relationship to body size. Oecologia 2007;153(3):589-96.

Habel JC, Dengler J, Janisova M, Toeroek P, Wellstein C, Wiezik M. European grassland ecosystems: Threatened hotspots of biodiversity. Biodiversity and Conservation 2013;22(10):2131-8.

Habel JC, Ulrich W, Schmitt T. Butterflies in corridors: quality matters for specialists. Insect Conserv Divers 2020;13(1):91-8.

Hagen M, Kissling WD, Rasmussen C, Am Aguiar M de, Brown LE, Carstensen DW et al. Biodiversity, species interactions and ecological networks in a fragmented world. In: Advances in ecological research: Elsevier; 2012. p. 89-210.

Hanski I, Kuussaari M, Nieminen M. Metapopulation structure and migration in the butterfly Melitaea cinxia. Ecology 1994;75(3):747-62.

Hanski I, Ovaskainen O. The metapopulation capacity of a fragmented landscape. Nature 2000;404(6779):755-8.

Hass AL, Brachmann L, Batáry P, Clough Y, Behling H, Tscharntke T. Maize-dominated landscapes reduce bumblebee colony growth through pollen diversity loss. J Appl Ecol 2019;56(2):294-304.

Hesselbarth MHK, Sciaini M, With KA, Wiegand K, Nowosad J. landscapemetrics an opensource R tool to calculate landscape metrics. Ecography 2019;42(10):1648-57.

Holzschuh A, Steffan-Dewenter I, Tscharntke T. Grass strip corridors in agricultural landscapes enhance nest-site colonization by solitary wasps. Ecological applications a publication of the Ecological Society of America 2009;19(1):123-32.

Hopfenmüller S, Steffan-Dewenter I, Holzschuh A. Trait-specific responses of wild bee communities to landscape composition, configuration and local factors. PloS one 2014;9(8):e104439.

Isaacs R, Tuell J, Fiedler A, Gardiner M, Landis D. Maximizing arthropod-mediated ecosystem services in agricultural landscapes: The role of native plants. Frontiers in Ecology and the Environment 2009;7(4):196-203. 
Jauker B, Krauss J, Jauker F, Steffan-Dewenter I. Linking life history traits to pollinator loss in fragmented calcareous grasslands. Landscape Ecology 2013;28(1):107-20. http://dx.doi.org/10.1007/s10980-012-9820-6.

Jordán F. Keystone species and food webs. Philosophical transactions of the Royal Society of London. Series B, Biological sciences 2009;364(1524):1733-41.

Klaus F, Bass J, Marholt L, Müller B, Klatt B, Kormann U. Hedgerows Have a Barrier Effect and Channel Pollinator Movement in the Agricultural Landscape. Journal of Landscape Ecology 2015;8(1):22-31.

Kleijn D, Baquero RA, Clough Y, Díaz M, Esteban J de, Fernández F et al. Mixed biodiversity benefits of agri-environment schemes in five European countries. Ecology letters 2006;9(3):243-54; discussion 254-7.

Krauss J, Steffan-Dewenter I, Tscharntke T. How does landscape context contribute to effects of habitat fragmentation on diversity and population density of butterflies? J Biogeography 2003a;30(6):889-900.

Krauss J, Steffan-Dewenter I, Tscharntke T. Local species immigration, extinction, and turnover of butterflies in relation to habitat area and habitat isolation. Oecologia 2003b;137(4):591-602.

Landi P, Minoarivelo HO, Brännström Å, Hui C, Dieckmann U. Complexity and stability of ecological networks: a review of the theory. Population ecology 2018;60(4):319-45.

Landis DA, Menalled FD, Costamagna AC, Wilkinson TK. Manipulating plant resources to enhance beneficial arthropods in agricultural landscapes. Weed sci. 2005;53(6):902-8.

Leidenfrost RM, Bänsch S, Prudnikow L, Brenig B, Westphal C, Wünschiers R. Analyzing the Dietary Diary of Bumble Bee. Frontiers in plant science 2020;11:287.

Lenth RV. Using lsmeans. J Stat Softw 2017;69:1-33.

Magnusson A, Skaug H, Nielsen A, Berg C, Kristensen K, Maechler M et al. Package 'glmmTMB'. R Package Version 0.2. 02017.

Memmott J. The structure of a plant-pollinator food web. Ecology letters 1999;2(5):276-80.

Morán-López T, Espíndola WD, Vizzachero BS, Fontanella A, Salinas L, Arana C et al. Can network metrics predict vulnerability and species roles in bird-dispersed plant communities? Not without behaviour. Ecology letters 2020.

Nowicki P, Vrabec V, Binzenhöfer B, Feil J, Zakšek B, Hovestadt T et al. Butterfly dispersal in inhospitable matrix: Rare, risky, but long-distance. Landscape Ecol 2014;29(3):401-12. 
Olesen JM, Bascompte J, Dupont YL, Jordano P. The modularity of pollination networks. Proceedings of the National Academy of Sciences of the United States of America 2007;104(50):19891-6.

Ollerton J, Winfree R, Tarrant S. How many flowering plants are pollinated by animals? OIKOS 2011;120(3):321-6.

Pellissier L, Albouy C, Bascompte J, Farwig N, Graham C, Loreau M et al. Comparing species interaction networks along environmental gradients. Biological Reviews 2018;93(2):785800.

Piqueray J, Bisteau E, Cristofoli S, Palm R, Poschlod P, Mahy G. Plant species extinction debt in a temperate biodiversity hotspot: Community, species and functional traits approaches. Biological Conservation 2011;144(5):1619-29.

Ribeiro MC, Metzger JP, Martensen AC, Ponzoni FJ, Hirota MM. The Brazilian Atlantic Forest: How much is left, and how is the remaining forest distributed? Implications for conservation. Biological Conservation 2009;142(6):1141-53.

Rösch V, Tscharntke T, Scherber C, Batáry P. Biodiversity conservation across taxa and landscapes requires many small as well as single large habitat fragments. Oecologia 2015;179(1):209-22.

Schmitt T. Biology and biogeography of the chalk-hill blue Polyommatus coridon - insect of the year 2015 for Germany, Austria and Switzerland. NL 2015;38(2):107-26.

Schmitt T, Habel JC, Besold J, Becker T, Johnen L, Knolle M et al. The Chalk-hill Blue Polyommatus coridon (Lycaenidae, Lepidoptera) in a highly fragmented landscape: How sedentary is a sedentary butterfly? J Insect Conserv 2006;10(4):311-6.

Segura C, Feriche M, Pleguezuelos JM, Santos X. Specialist and generalist species in habitat use: implications for conservation assessment in snakes. Journal of Natural History 2007;41(41-44):2765-74.

Sirami C, Gross N, Baillod AB, Bertrand C, Carrié R, Hass A et al. Increasing crop heterogeneity enhances multitrophic diversity across agricultural regions. Proceedings of the National Academy of Sciences of the United States of America 2019;116(33):16442-7.

Spiesman BJ, Inouye BD. Habitat loss alters the architecture of plant-pollinator interaction networks. ECOLOGY 2013;94(12):2688-96.

Steffan-Dewenter I, Munzenberg U, Burger C, Thies C, Tscharntke T. Scale-dependent effects of landscape context on three pollinator guilds. Ecology 2002;83(5):1421-32.

Steffan-Dewenter I, Tscharntke T. Effects of habitat isolation on pollinator communities and seed set. Oecologia 1999;121(3):432-40. 
Steffan-Dewenter I, Tscharntke T. Insect communities and biotic interactions on fragmented calcareous grasslands - a mini review. Biological Conservation 2002;104(3):275-84.

Sterry P, Mackay A. Butterflies and moths of Britain and Europe (Pocket Nature Series). London, Dorling Kindersley 2004.

Stevens VM, Trochet A, Blanchet S, Moulherat S, Clobert J, Baguette M. Dispersal syndromes and the use of life-histories to predict dispersal. Evolutionary applications 2013;6(4):63042.

Thébault E, Fontaine C. Stability of ecological communities and the architecture of mutualistic and trophic networks. Science (New York, N.Y.) 2010;329(5993):853-6.

Thomas CD, Thomas JA, Warren MS. Distributions of occupied and vacant butterfly habitats in fragmented landscapes. Oecologia 1992;92(4):563-7.

Traill LW, Lim MLM, Sodhi NS, Bradshaw CJA. Mechanisms driving change: altered species interactions and ecosystem function through global warming. The Journal of animal ecology 2010;79(5):937-47.

Tscharntke T, Steffan-Dewenter I, Kruess A, Thies C. Contribution of small habitat fragments to conservation of insect communities of grassland-cropland landscapes. Ecological applications a publication of the Ecological Society of America 2002;12(2):354-63.

Tylianakis JM, Laliberté E, Nielsen A, Bascompte J. Conservation of species interaction networks. Biological Conservation 2010;143(10):2270-9.

Tylianakis JM, Morris RJ. Ecological Networks Across Environmental Gradients. Annu. Rev. Ecol. Evol. Syst. 2017;48(1):25-48.

Valiente-Banuet A, Aizen MA, Alcántara JM, Arroyo J, Cocucci A, Galetti M et al. Beyond species loss: the extinction of ecological interactions in a changing world. Funct Ecol 2015;29(3):299-307.

van Geert A, van Rossum F, Triest L. Do linear landscape elements in farmland act as biological corridors for pollen dispersal? Journal of Ecology 2010;98(1):178-87.

van Halder I, Thierry M, Villemey A, Ouin A, Archaux F, Barbaro L et al. Trait-driven responses of grassland butterflies to habitat quality and matrix composition in mosaic agricultural landscapes. Insect Conservation and Diversity 2017;10(1):64-77.

van Swaay CAM. The importance of calcareous grasslands for butterflies in Europe. Biological Conservation 2002;104(3):315-8.

van Swaay CAM, Brereton T, Kirkland P, Warren MS. Manual for butterfly monitoring. Report VS2012 2012;10. 
WallisDeVries MF, Poschlod P, Willems JH. Challenges for the conservation of calcareous grasslands in northwestern Europe: Integrating the requirements of flora and fauna. Biological Conservation 2002;104(3):265-73.

Westphal C, Steffan-Dewenter I, Tscharntke T. Bumblebees experience landscapes at different spatial scales: possible implications for coexistence. Oecologia 2006;149(2):289-300.

Westrich P. Die Wildbienen Deutschlands: Verlag Eugen Ulmer; 2018. 


\section{Supplementary material}

Connectivity index based on Hanski et al. 1994

$$
I=\sum e^{-d i j} A_{j}
$$

$\mathrm{Aj}$ is the size in $\mathrm{m}^{2}$ of neighbouring calcareous grasslands and dij is the distance in $\mathrm{km}$ from the neighbouring grassland $\mathrm{j}$ to the study site I (following Krauss et al. 2004). The $2 \mathrm{~km}$ radius was chosen to capture the maximum biologically meaningful distance for the largest pollinators (see also Krauss et al. 2010). Larger values of "I" indicate higher connectivity (Table S1).

Table S1. Landscape metrics for each study site: Area in $\mathrm{m}^{2}$, management, Shannon diversity index of cover types in a $200 \mathrm{~m}$ radius and connectivity index.

\begin{tabular}{|c|c|c|c|c|}
\hline Study site & $\begin{array}{c}\text { Habitat area } \\
\left(\mathrm{m}^{2}\right)\end{array}$ & Management & $\begin{array}{c}\text { Shannon index } \\
(200 \mathrm{~m})\end{array}$ & $\begin{array}{c}\text { Connectivity } \\
\text { index }\end{array}$ \\
\hline Huhnsberg & 52557 & Grazing & 1.50 & 52162 \\
\hline Mühlenberg & 50673 & Grazing & 1.89 & 15805 \\
\hline Aschenburg & 35479 & Grazing & 1.45 & 19917 \\
\hline Ellershagen & 33186 & Grazing & 0.68 & 7145 \\
\hline Lengender Burg & 16804 & Unmanaged & 1.68 & 4914 \\
\hline Dehnerberg & 12724 & Grazing & 1.85 & 3671 \\
\hline Mackenrodt & 11612 & Mowing & 1.71 & 637 \\
\hline Burgbreite & 7641 & Grazing & 1.28 & 7335 \\
\hline Gladeberg & 7288 & Grazing & 1.19 & 3814 \\
\hline Weinberg & 6641 & Grazing & 1.71 & 25941 \\
\hline Hackelberg & 5823 & Mowing & 1.58 & 28463 \\
\hline Am Graben & 5535 & Unmanaged & 1.93 & 1186 \\
\hline Tiefetal & 4132 & Grazing & 1.36 & 4617 \\
\hline Südlicher Riesenberg & 3535 & Unmanaged & 1.76 & 6103 \\
\hline
\end{tabular}




\begin{tabular}{|c|c|c|c|c|}
\hline Ossenfelder Bahndamm & 3504 & Grazing & 1.86 & 1111 \\
\hline Kleiner Knull & 3467 & Grazing & 1.55 & 8083 \\
\hline Kuhberg & 3465 & Grazing & 1.78 & 10797 \\
\hline Eschenberg & 1861 & Unmanaged & 1.36 & 306 \\
\hline Vor dem roten Berge & 1462 & Unmanaged & 1.23 & 21676 \\
\hline Auf dem Klee & 778 & Unmanaged & 1.45 & 25575 \\
\hline Schweineberg & 701 & Mowing & 1.70 & 114 \\
\hline Am Hopfenberge & 693 & Unmanaged & 1.34 & 19917 \\
\hline Unter den Niederwiesen & 406 & Mowing & 0.49 & 5332 \\
\hline Emme & 381 & Unmanaged & 0.85 & 10015 \\
\hline Gieseberg Süd & 353 & Unmanaged & 1.71 & 15953 \\
\hline Mühlenberg 2 & 228 & Mowing & 1.12 & 47366 \\
\hline Zipfel am Lindenberg & 227 & Unmanaged & 1.37 & 10518 \\
\hline Lieseberg & 144 & Unmanaged & 1.24 & 2943 \\
\hline Heikenrott & 82 & Mowing & 1.28 & 6152 \\
\hline
\end{tabular}


Table S2. Minimum adequate models for interaction and fragment degree centrality selected with likelihood ratio tests (via “drop1”). Significance levels: ***p<0.001. **p<0.01, *p<0.05

\begin{tabular}{|c|c|c|c|c|}
\hline $\begin{array}{c}\text { Response } \\
\text { variable }\end{array}$ & Model & Fixed effects & $\begin{array}{c}\text { LRT } \\
\left(\mathrm{Chi}^{2}\right)\end{array}$ & $P$ \\
\hline $\begin{array}{l}\text { Interaction } \\
\text { degree }\end{array}$ & 1 & $\begin{array}{l}\text { Months active plant } \\
\text { Months active pollinator } \\
\text { Plant habitat specialization }\end{array}$ & $\begin{array}{l}42.30 \\
24.80 \\
12.78\end{array}$ & $\begin{array}{l}<0.001 * * * \\
<0.001 * * * \\
<0.001 * * *\end{array}$ \\
\hline $\begin{array}{l}\text { Interaction } \\
\text { weighted } \\
\text { degree }\end{array}$ & 2 & $\begin{array}{l}\text { Pollinator identity } \\
\text { Months active plant } \\
\text { Months active visitor } \\
\text { Plant habitat specialization: Pollinator size }\end{array}$ & $\begin{array}{c}8.74 \\
24.86 \\
6.64 \\
5.28\end{array}$ & $\begin{aligned} & 0.012^{*} \\
< & 0.001 * * * \\
& 0.010^{*} \\
& 0.021^{*}\end{aligned}$ \\
\hline $\begin{array}{l}\text { Fragment } \\
\text { degree }\end{array}$ & 3 & $\begin{array}{l}(\log ) \text { Fragment area } \\
\text { Landscape diversity }(200 \mathrm{~m})\end{array}$ & $\begin{array}{c}4.24 \\
16.04\end{array}$ & $\begin{aligned} & 0.040^{*} \\
< & 0.001 * * *\end{aligned}$ \\
\hline $\begin{array}{l}\text { Fragment } \\
\text { weighted } \\
\text { degree }\end{array}$ & 4 & $\begin{array}{l}\text { (log) Fragment area } \\
\text { Landscape diversity }(150 \mathrm{~m})\end{array}$ & $\begin{array}{l}11.40 \\
12.54\end{array}$ & $\begin{array}{l}<0.001 * * * \\
<0.001 * * *\end{array}$ \\
\hline
\end{tabular}


Table S3. Full and minimum adequate models for unique interactions and unique interactions' proportion. Minimum adequate models were selected with likelihood ratio tests (via "drop1"). Significance levels: $* * * p<0.001 . * * p<0.01, * p<0.05$

\begin{tabular}{|c|c|c|c|c|}
\hline $\begin{array}{c}\text { Response } \\
\text { variable }\end{array}$ & Model & Fixed effects & LRT & $\boldsymbol{P}$ \\
\hline $\begin{array}{l}\text { Unique } \\
\text { interactions }\end{array}$ & Full & $\begin{array}{l}\text { Landscape diversity }(100 \mathrm{~m}) \\
\text { (log) Fragment area } \\
\text { (log) Connectivity Index }\end{array}$ & $\begin{array}{c}9.34 \\
0.092 \\
0.60\end{array}$ & $\begin{array}{l}0.002 * * \\
0.76 \\
0.44\end{array}$ \\
\hline $\begin{array}{l}\text { Unique } \\
\text { interactions }\end{array}$ & Min & Landscape diversity (100 m) & 12.52 & $<0.001 * * *$ \\
\hline $\begin{array}{l}\text { Unique } \\
\text { interactions' } \\
\text { proportion }\end{array}$ & Full & $\begin{array}{l}\text { Landscape diversity }(500 \mathrm{~m}) \\
(\log ) \text { Fragment area } \\
(\log ) \text { Connectivity Index }\end{array}$ & $\begin{array}{l}6.88 \\
0.88 \\
2.30\end{array}$ & $\begin{array}{c}0.014^{*} \\
0.36 \\
0.14\end{array}$ \\
\hline $\begin{array}{l}\text { Unique } \\
\text { interactions' } \\
\text { proportion }\end{array}$ & Min & Landscape diversity $(500 \mathrm{~m})$ & 8.08 & $0.008 * *$ \\
\hline
\end{tabular}




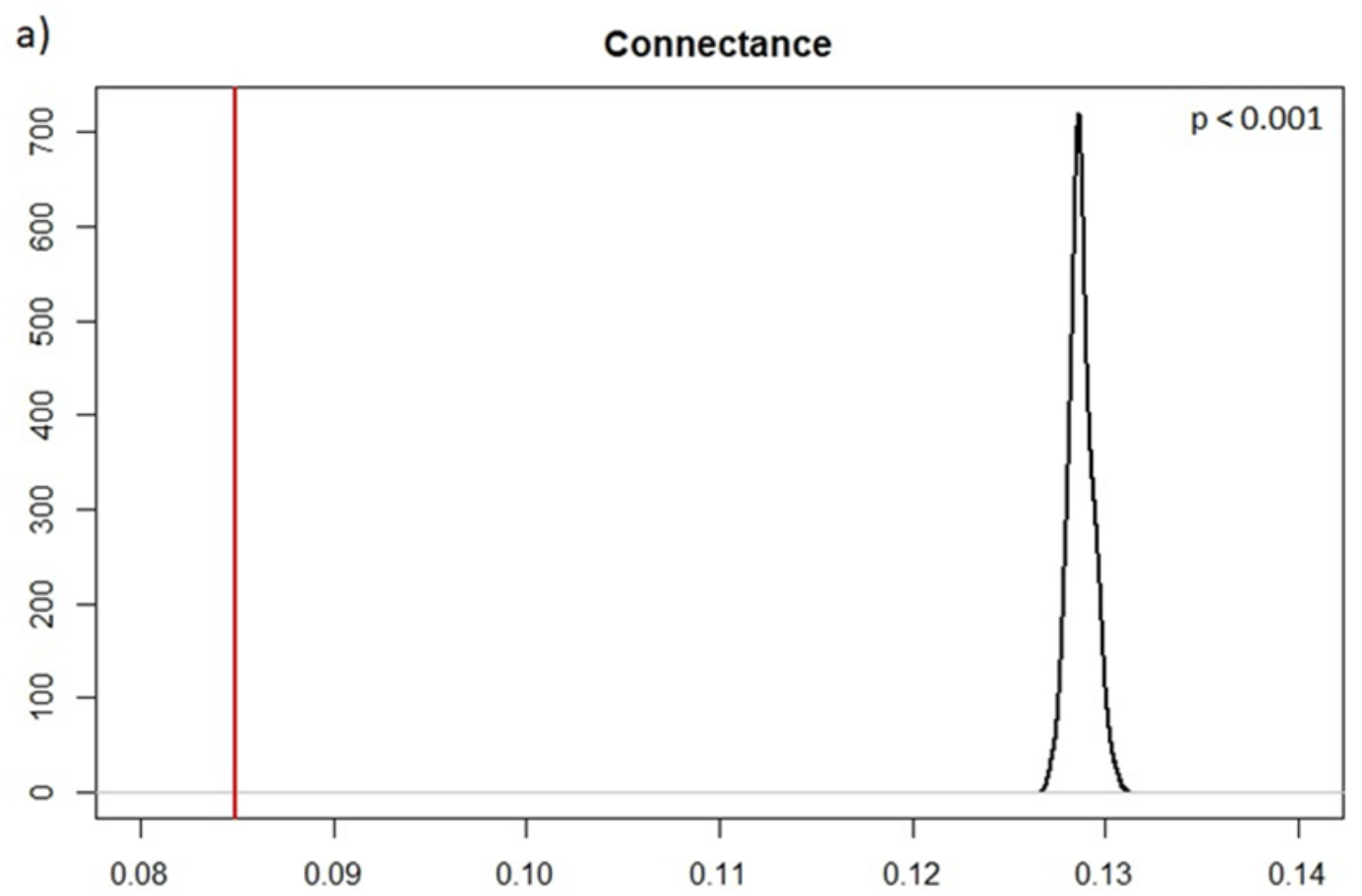

b) Modularity

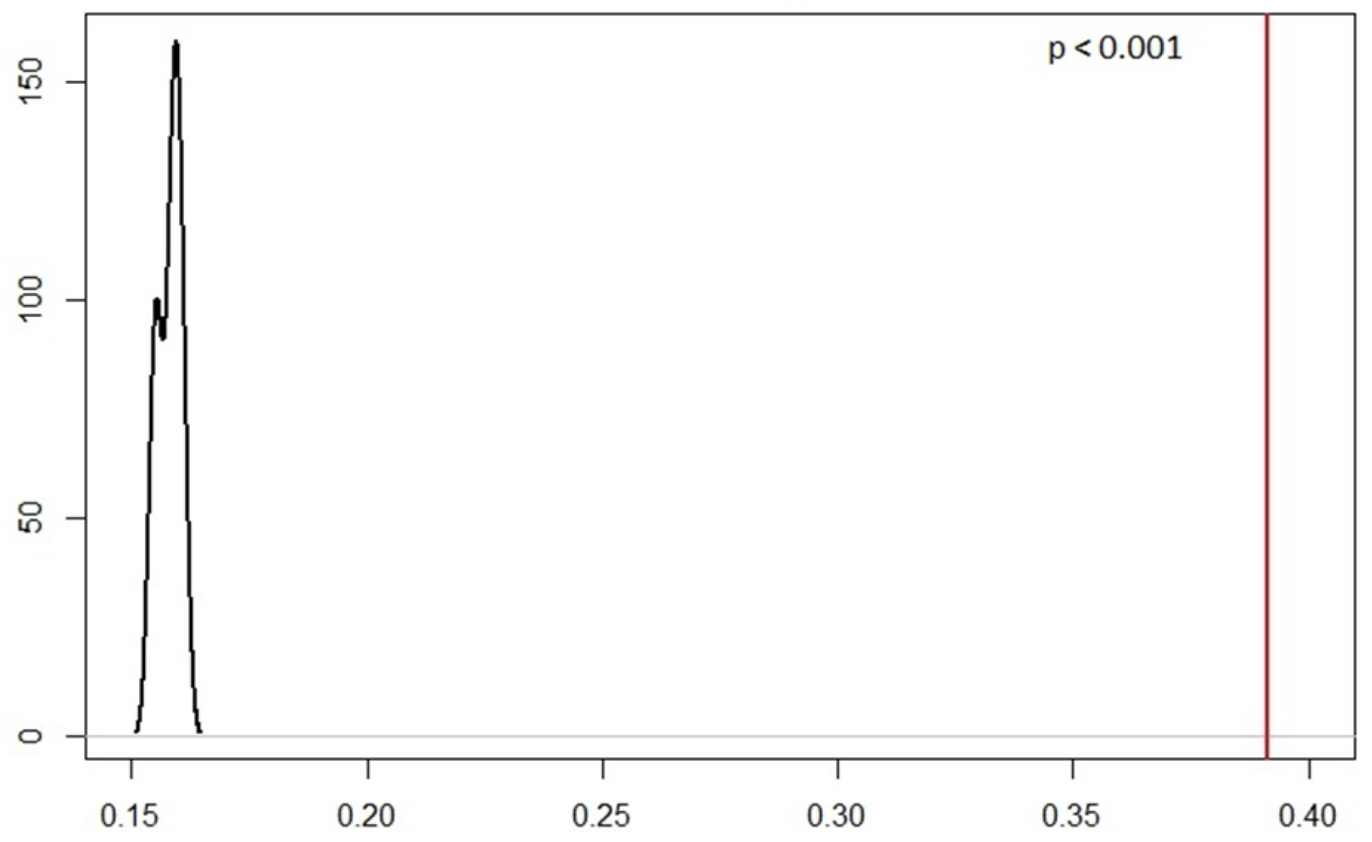

Figure S1. Connectance (a) and modularity (b) of our plant-pollinator metanetwork (red vertical line) compared to null models (grey distribution). 


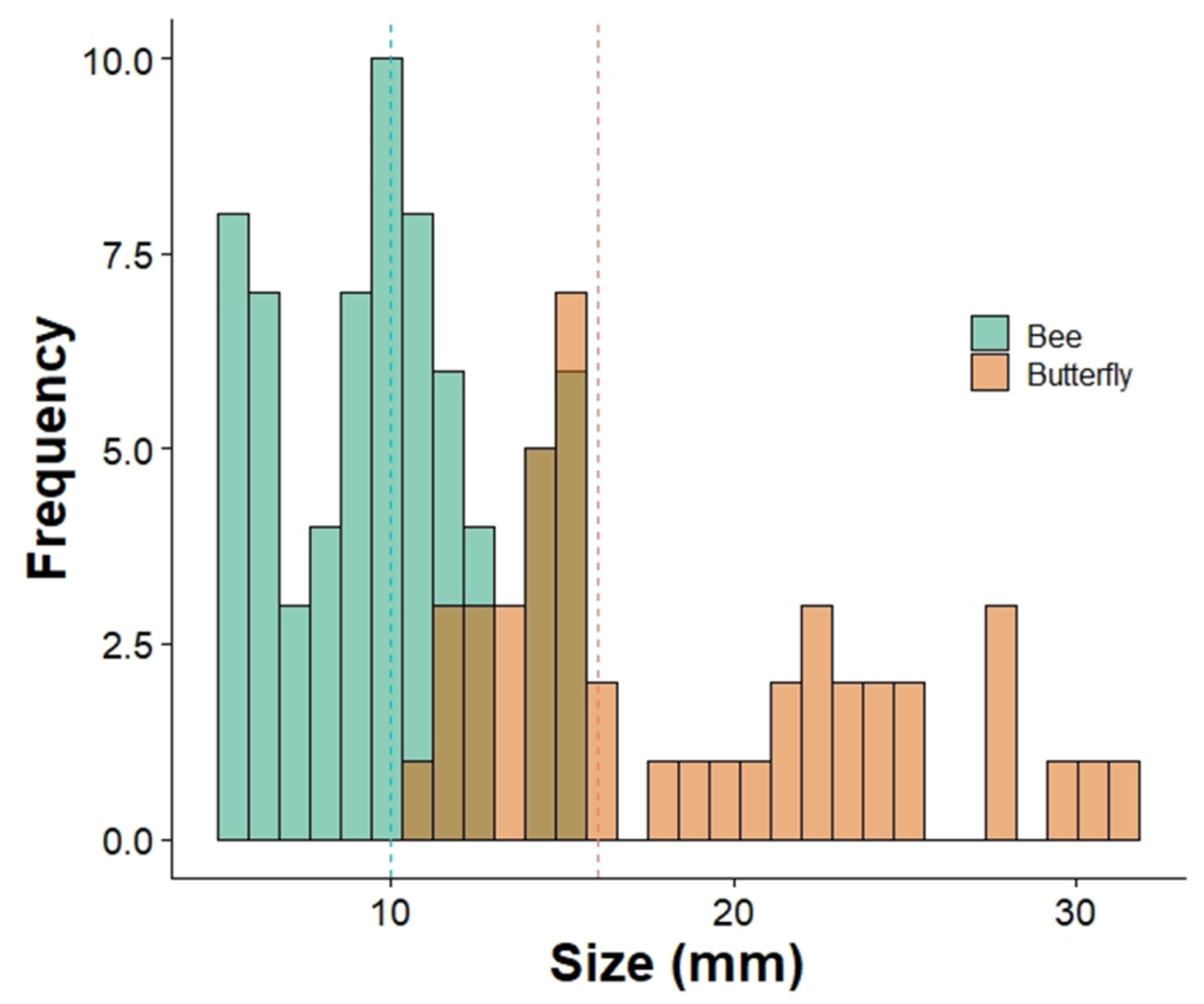

Figure S2. Histogram of bees' and butterflies' sizes (body size and wingspan, respectively. The dashed vertical lines represent the median size for each group. 


\section{Chapter 3}

\section{Pollination networks in fragmented landscapes are more specialized for pollen transport than flower visitation}

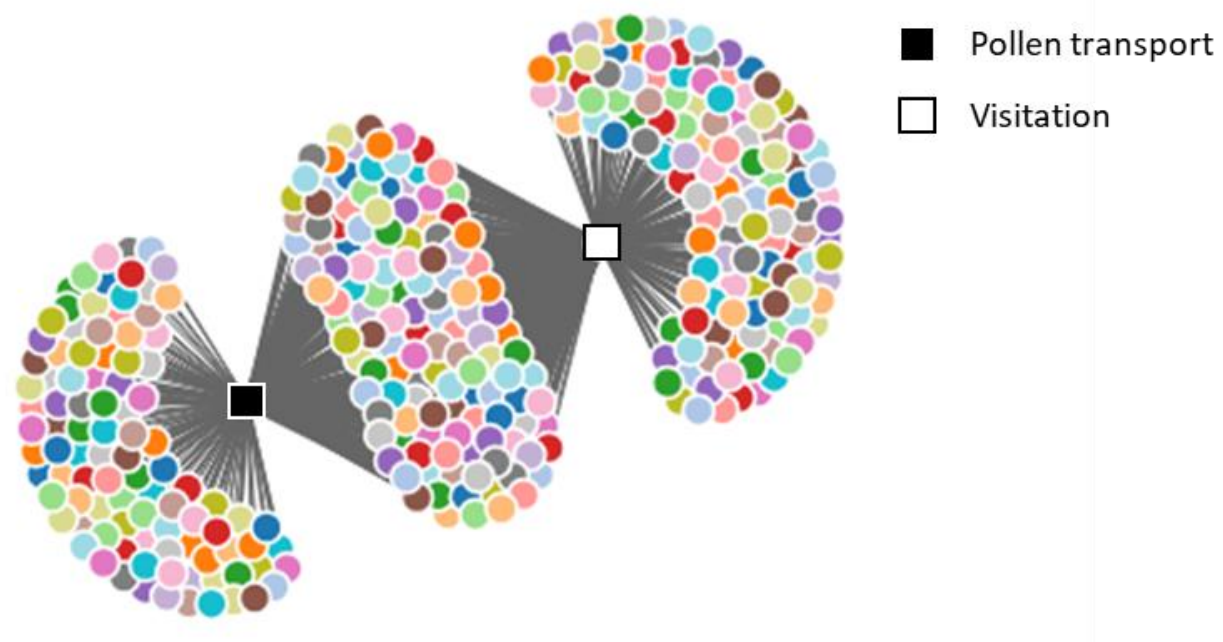

Felipe Librán-Embid, Ingo Grass, Carine Emer, Viviana Alarcón, Hermann Behling, Siria Biagioni, Cristina Ganuza, Celina Herrera-Krings, Christina Ani Setyaningsih \& Teja Tscharntke 


\begin{abstract}
Plant-pollinator networks are key to the functioning of natural and human-modified ecosystems. Habitat fragmentation and landscape simplification effects on mutualistic networks have been studied to some extent, but studies comparing pollination networks based on flower visitation and those based on pollen loads across landscape gradients are missing. Here we contrasted visitation with pollen transport networks in 29 fragments of calcareous grassland, a highly endangered biodiversity hotspot. We found that only $37 \%$ of the total unique pairwise interactions occurred in both types of networks, $28 \%$ of these were only registered through pollen load analyses and $49 \%$ of the observed flower-pollinator interactions did not translate into pollen transport. Network specialization was higher in pollen transport networks and was negatively related to the diversity of land cover types in the surrounding landscapes. The number of single-fragment interactions as well as the proportion of single-fragment interactions increased with landscape diversity in the pollen transport networks. Finally, at the metanetwork level, the most central plant and pollinator species are shared between the visitation and pollen transport metanetworks. In conclusion, our results reveal that flower visitation and pollen transport data give different, but complementary information, while none can be used as a surrogate of the other. Higher specialization of pollen transport networks indicates that network vulnerability could be higher than hitherto expected from visitation networks. Our results also reveal a surprisingly high number of rare pollen transport interactions, particularly in diverse landscapes, which would have been undetected in a classical flower visitation study.
\end{abstract}




\section{Introduction}

Plant-pollinator networks have been traditionally constructed using data on flower visitation (Ballantyne et al., 2015). However, in order for pollination to occur, viable pollen grains need to be transported from the anthers of a flowering plant to a receptive stigma of a conspecific. Therefore, the solely visitation of an animal to a flower is expected to be a poor predictor of its capacity as a pollinator (King et al., 2013). For instance, many flower visitors forage exclusively for nectar (e.g. most butterflies) and do not contact flower anthers; other species lack morphological traits to carry pollen and thus cannot act as pollinators (Genini et al., 2010; Stavert et al., 2016). Two methods have been proposed to overcome this challenge. First, stigmas and styles can be analyzed to identify pollen deposition after an animal visit (Emer et al., 2015). Yet, this method is extremely time-consuming and consequently prohibitive for landscape scale studies. Alternatively, flower visitors' pollen loads can be analyzed to check for their pollen transport capacity (Zhao et al., 2019). Although not as close to pollination as direct pollen deposition measures, this method can also provide valuable information regarding an animal capacity as a pollinator. Furthermore, given its relative simplicity, it is suitable for large scale studies.

Pollen transport networks have been recently constructed at singular sites and local scales (Alarcón, 2010; Gresty et al., 2018; Lopezaraiza-Mikel et al., 2007). However, landscape scale effects, and in particular, habitat fragmentation effects on plant-pollinator networks are essential to understand their dynamics under land use change (Grass et al., 2018; Xiao et al., 2016). In spite of this, to our knowledge, there is no study analyzing landscape scale effects on pollen transport networks over a gradient of habitat size and isolation. Originating from the concept of "multilayer" networks (Pilosof et al., 2017), metanetworks (i.e. a group of scattered local networks connected by species dispersal) are an emerging approach to study the consequences of habitat fragmentation on ecological networks at landscape and regional scales (González et al., 2018; Hagen et al., 2012). The identification of the most important species for metanetwork integrity can guide environmental policy and conservation efforts. A metanetwork can be constructed using habitat fragments and plant or pollinator species as the interacting units (i.e. nodes).

Node importance can be quantified through the concept of node centrality (Domínguez-García and Muñoz, 2015; Jordán, 2009). Central nodes are characterized by having the most detrimental 
effects on the integrity of a metanetwork once removed (e.g. most associated co-extinctions; González et al., 2010). Moreover, species traits can be related to species centrality in ecological networks (Morán-López et al., 2020). In particular, species body size and habitat specialization have been found to affect species' ecological roles and functions (Gathmann and Tscharntke, 2002; Grass et al., 2018; Westphal et al., 2006). Species traits can also determine the probability of an interaction being detected with flower visitation observations, pollen loads analyses or both. For example, given that social bees are usually more effective pollen vectors (sensu Freitas, 2013) and more abundant than solitary bees, interactions established by social bees should have a higher probability of occurrence in visitation and pollen transport networks simultaneously. Furthermore, habitat specialist plants, differently from habitat generalists, can have adaptations to maximize pollen dispersal through pollinators (Miller-Struttmann, 2013) and, hence, should also establish interactions with a higher probability of occurrence in both types of networks.

Here, we constructed pollination networks at the flower visitation and pollen transport levels, over a gradient of habitat fragmentation of European calcareous grasslands, a highly threatened biodiversity hotspot, characterized by a vast number of rare and endangered species (Habel et al., 2013). We compared the structure of local visitation and pollen transport networks in terms of network specialization and connectance. Furthermore, we explored fragmentation effects on them. To this end, we identified the most central species in both metanetworks and studied their functional traits (body size, habitat specialization). In addition, we aimed to analyze the differences and similarities among the observational and pollen loads data for the description of the plant-pollinator networks dynamics and to explore the consequences of the conclusions derived from both methods. Therefore, we analyzed which functional traits of the plant-pollinator interaction pairs relate to the probability of them occurring in the visitation and pollen transport networks. Finally, we studied the effects of landscape structure on the occurrence of singlefragment interactions in local networks.

We hypothesized that: (i) the specialization of local pollen transport networks will be higher than that of local visitation networks given that not all flower visitors are expected to carry pollen on their bodies; (ii) network specialization will decrease in larger and more connected habitats and also with landscape diversity, as the presence of more species should increase the probability of multiple interacting partners; (iii) due to many rare and ineffective interactions (i.e. interactions that contribute little to the plant reproductive success, sensu Freitas, 2013), a high number of 
interactions unique to the visitation and pollen transport metanetworks is expected; (iv) the most central species at the metacommunity level are expected to be the same in the visitation and pollen transport metanetworks, despite projected differences between network types; (v) the probability of interaction occurrence in both network types depends on pollinator identity (i.e. bumblebee or solitary bee) and plant habitat specialization; (vi) finally, we expect that the number and proportion of single-fragment interactions increases with landscape diversity and with habitat size and connectivity in both types of networks.

\section{Methods}

\section{Study area}

Data was collected from April until August 2018 on 29 calcareous grasslands in the surroundings of the city of Göttingen (Germany). These grasslands were selected in a previous study (Krauss et al., 2003a), from a larger regional pool ( 300), to vary along independent gradients of size and isolation from other calcareous grasslands. Arable land and European beech (Fagus sylvatica) forests are the two main land use types in the region with $31 \%$ and $38 \%$ land cover, respectively (Krauss et al., 2003a).

\section{Landscape metrics}

We tested the effects of fragment size, fragment connectivity and landscape diversity of cover types on the structure of local fragment networks in terms of specialization and connectance and also on the number and proportion of single-fragment interactions per fragment. Fragment area was calculated with ArcGis 10.5.1 and ranged from $82 \mathrm{~m}^{2}$ to $52557 \mathrm{~m}^{2}$, excluding zones dominated by shrubs. Fragment spatial connectivity and the Shannon diversity of cover types (as a measure of landscape diversity) were calculated using the "landscapemetrics" package (Hesselbarth et al., 2019). For fragments' spatial connectivity we used a connectivity index developed by Hanski et al. (1994) and considered all calcareous grasslands in a radius of $2 \mathrm{~km}$ around the study grasslands (see SI for details). Larger values of this index indicate higher spatial connectivity (Table S1). The mapped cover types were: oilseed rape, grainfield, maize, other crops, forest open, forest closed, field margin, hedgerow, pasture, calcareous grassland, orchard, settlements, water bodies, streets, grassroads and bare soil. Shapefiles of land use were 
constructed using ArcGis 10.5.1 and all statistics were performed in R (R Development Core Team 2019).

\section{Flower visitation data}

We performed three rounds of sampling throughout the season in each calcareous grassland to capture the succession of flower visitors (hereafter, pollinators) and wildflower species. Seven observation plots of 10 min were established in each site. We followed a protocol established by van Swaay et al. (2012) to carry out our surveys. We collected data from 9:00 to 17:00 on days with a minimum temperature of $15{ }^{\circ} \mathrm{C}$ and at least $50 \%$ clear sky, or with a minimum temperature of $18{ }^{\circ} \mathrm{C}$ in any sky condition. To avoid any confounding effect of daytime sites were surveyed at different times of the day.

Our observational plots were established in flower-rich areas and were circular ( $3 \mathrm{~m}$ radius, 28.3 $\mathrm{m}^{2}$ ). Within these, all interactions between bees (Hymenoptera: Apiformes) and flowering plants were registered. A visit by a bee was considered to be an interaction as soon as the insect touched the plant reproductive organs. Bees not easily recognizable at a distance were captured with a sweep net and photographed or collected for later identification by taxonomists. The timer was paused while handling insects. We excluded interactions involving Apis mellifera as the presence of this species in our region was solely related to the existence of bee keepers in the surroundings. A. mellifera interactions accounted for 334 from a total of 1499 interactions registered and were present in all sites (range 1-75 A. mellifera interactions per site). Bees were classified in solitary bees or bumblebees (hereafter, bee identity). All bumblebees are social and belong to the genus Bombus spp.. Within the group of "solitary bees", seven species present some degree of sociality but were grouped within the solitary bees because of the morphological and genetic similarities with these. The seven species are: Andrena scotica (communal), Halictus confusus, Halictus rubicundus, Halictus tumulorum, Lasioglossum calceatum, Lasioglossum morio and Lasioglossum pauxillum.

\section{Plant-pollinator traits}

Plants and pollinators were classified according to their life-history traits, following Piqueray et al. (2011), Jauker et al. (2013) and Hopfenmüller et al. (2014) for plants' and bees' habitat specialization, respectively. Bees were considered large when having a body length of $10 \mathrm{~mm}$ or more (median body length of bees) and were otherwise considered small. All body length values 
for bees were taken from Westrich (2018). We consider Cirsium sp. (cluster of four species mostly represented by the habitat specialist Cirsium acaule) and Ononis sp. (cluster of two hybridizing species including the specialist Ononis repens) as habitat specialists.

\section{Pollen load data}

Pollen was taken from bees' bodies, head and antennae by bathing bees in Eppendorf tubes filled with distilled water (modified protocol from Dafni, 1992). As some interactions were very abundant, we established a maximum of 6 pollen samples taken from the same interaction in each site and round. Samples were later acetolysed (Jones, 2014) using a protocol lab technique and analyzed using light microscopy at 40x magnification. We also created a reference collection of pollen from the flowering plants of the region to aid sample pollen identification. We did not consider slides with less than 30 pollen grains. From the remaining ones we counted 200 pollen grains in each slide, except five slides which had 50-200 pollen grains. Following Bosch et al. (2009), we considered the presence of at least 10 pollen grains in our samples as proof of true visitation to the corresponding flowering species.

\section{Network and statistical analysis}

Our study involved two levels of complexity: (i) local scale, in which we zoomed-in to compare flower-visitation vs pollen-transport networks types; (ii) regional scale, in which we scaled-up, from local fragment networks, to regional metanetworks. Below, we describe how we analyzed that complexity in the light of our hypotheses.

We constructed local quantitative bipartite networks (one for each fragment) and regional metanetworks using data on flower visitation (hereafter, visitation networks) and pollen loads (hereafter, pollen transport networks), respectively. Local bipartite networks were constructed as $\mathrm{a}_{i j}$ adjacency matrices in which $i$ are the plant species and $j$ the pollinator species. At the landscape level, metanetworks were built by pooling the 29 calcareous grasslands into $\mathrm{a}_{k l}$ adjacency matrices in which $k$ are the studied sites and $l$ the plant or pollinator species. To make visitation and pollen transport networks comparable we did not consider pollen from trees (e.g. Picea spp or Pinus spp), crops (e.g. Vicia faba), grasses (e.g. Poaceae) or ornamental plants (e.g. Astrantia major) as observations were done exclusively on herbaceous plants of calcareous grasslands. 
To test whether pollen transport networks were more specialized than visitation networks at the local level (hypothesis 1), and whether they were affected by habitat fragmentation and landscape diversity (hypothesis 2), we calculated the H2' index which measures the specialization of the network for each fragment (Blüthgen et al., 2006). We used a linear mixed model with fragment identity as random intercept and network type, (log) fragment area, (log) connectivity index and landscape diversity at $350 \mathrm{~m}$ as explanatory variables. To choose the spatial scale at which effects were stronger, we compared models fitted at all scales from $100 \mathrm{~m}$ to $500 \mathrm{~m}$ in $50 \mathrm{~m}$ intervals and compared them using the corrected Akaike information criterion for small samples (AICc). As almost all indices of network structure are more or less affected by network size, we standardized $\mathrm{H} 2$ ' relative to a null model to allow for meaningful comparisons among networks of different fragments (Dormann et al., 2009; Dormann and Strauss, 2014). We followed Grass et al. (2018) by creating null distributions based on 1000 replicates of Patefield's algorithm.

We estimated the centrality of the metanetworks nodes (hypothesis 4) by calculating: (1) species degree, as the number of fragments where a species occurs; (2) species betweenness centrality (hereafter, species betweenness), as the number of shortest paths among fragments going through the focal species; (3) weighted betweenness centrality, same as species betweenness but weighted by species abundance and; (4) proportional generality, as the number of fragments, where the focal species occurs, in relation to the total number of fragments in the metanetwork weighted by the species abundance. Betweenness centrality $>0$ indicates species that have the potential to connect the metanetwork to some extent, $\mathrm{BC}=0$ means that the focal node is exclusive to a single fragment. Network metrics were calculated using the "bipartite" package (Dormann et al., 2008).

We modelled the probability of the presence of interactions in both networks (hypothesis 5) using a generalized linear mixed model with binomial distribution and pollinator and plant species identity as crossed random intercepts. Network type was tested as a single explanatory variable. Finally, to study the relationship between landscape diversity and habitat fragmentation on the number and proportion of single-fragment interactions (hypothesis 6) we used generalized linear models with negative binomial distribution and linear models, respectively. 
The minimum adequate models were found with backwards model selection using likelihood ratio tests. All non-significant explanatory variables $(\mathrm{P}>0.05)$ were sequentially removed. All network and statistical analyses were performed in R (R Development Core Team 2019).

\section{Results}

We observed 1165 interaction events among 67 bee species and 71 plant species resulting in 250 unique pairwise interactions. Further, we analyzed pollen samples of 830 bee individuals and found 474 individuals carrying 0-30 pollen grains, 351 carrying $\geq 200$ pollen grains and 5 carrying 50-200 pollen grains. In total we identified 44 bee species transporting pollen of 64 plant species, resulting in 222 unique plant-bee pairwise interactions. Of those, 31 (43.7\%) plant species were only visited by bumblebees and 19 (26.8\%) plant species were only visited by solitary bees, while $23(32.4 \%)$ plant species were visited by both, totalizing 71 plant species visited (Fig. 1a, Table S2). Some examples include Fragaria vesca, which was only visited by solitary bees, and Trifolium pratense, Salvia pratensis, Prunella grandiflora, Carlina vulgaris and Anthyllis vulneraria, which were only visited by bumblebees (Table S2). Regarding pollen transport, $20(31.3 \%)$ plant species were only pollen-transported by bumblebees and the pollen of $12(18.8 \%)$ plant species was only transported by solitary bees (Fig. 1b, Table S3). The pollen of $32(50 \%)$ plant species was transported by both groups, summing up to 64 plant species that got their pollen transported by flower visitors. For example, pollen of Knautia arvensis was only transported by bumblebees and pollen of Potentilla sp. was only transported by solitary bees (Table S3). 
a) Visitation data

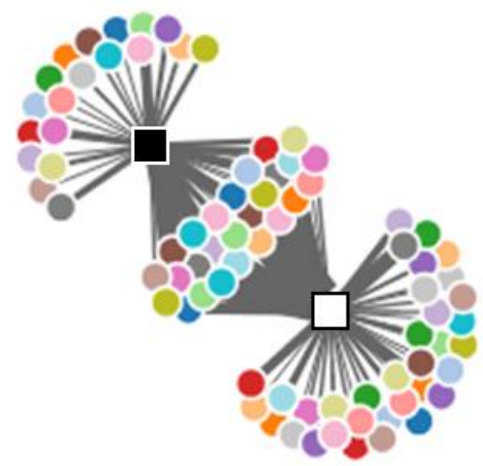

b) Pollen transport data

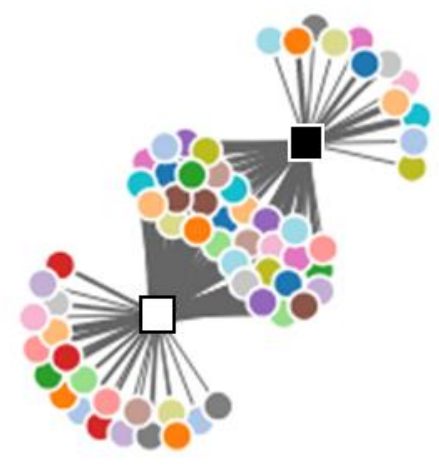

Solitary bee

Bumblebee

Figure 1. Network representation of the established interactions among bumblebees (white squares) and solitary bees (black squares) with plant species (circles) in a) the visitation dataset and b) the pollen transport dataset. Plants visited by both groups occur between the squares.

At the local network level, our results show that pollen transport networks were significantly more specialized than visitation networks $(\mathrm{F}=11.33, \mathrm{P}=0.002$, Fig. 2$)$. We also found a negative effect of landscape diversity at the $350 \mathrm{~m}$ scale on specialization of both visitation and pollen transport networks $(\mathrm{F}=13.56, \mathrm{P}=0.001$, Fig. 2$)$. On the other hand, network connectance did not differ between the visitation and pollen transport networks $(\mathrm{F}=1.03, \mathrm{P}=0.32)$ and was also not affected by landscape diversity $(\mathrm{F}=1.97, \mathrm{P}=0.17)$. Fragment area and fragment connectivity had no significant effects neither on network specialization nor network connectance (Table S4). 


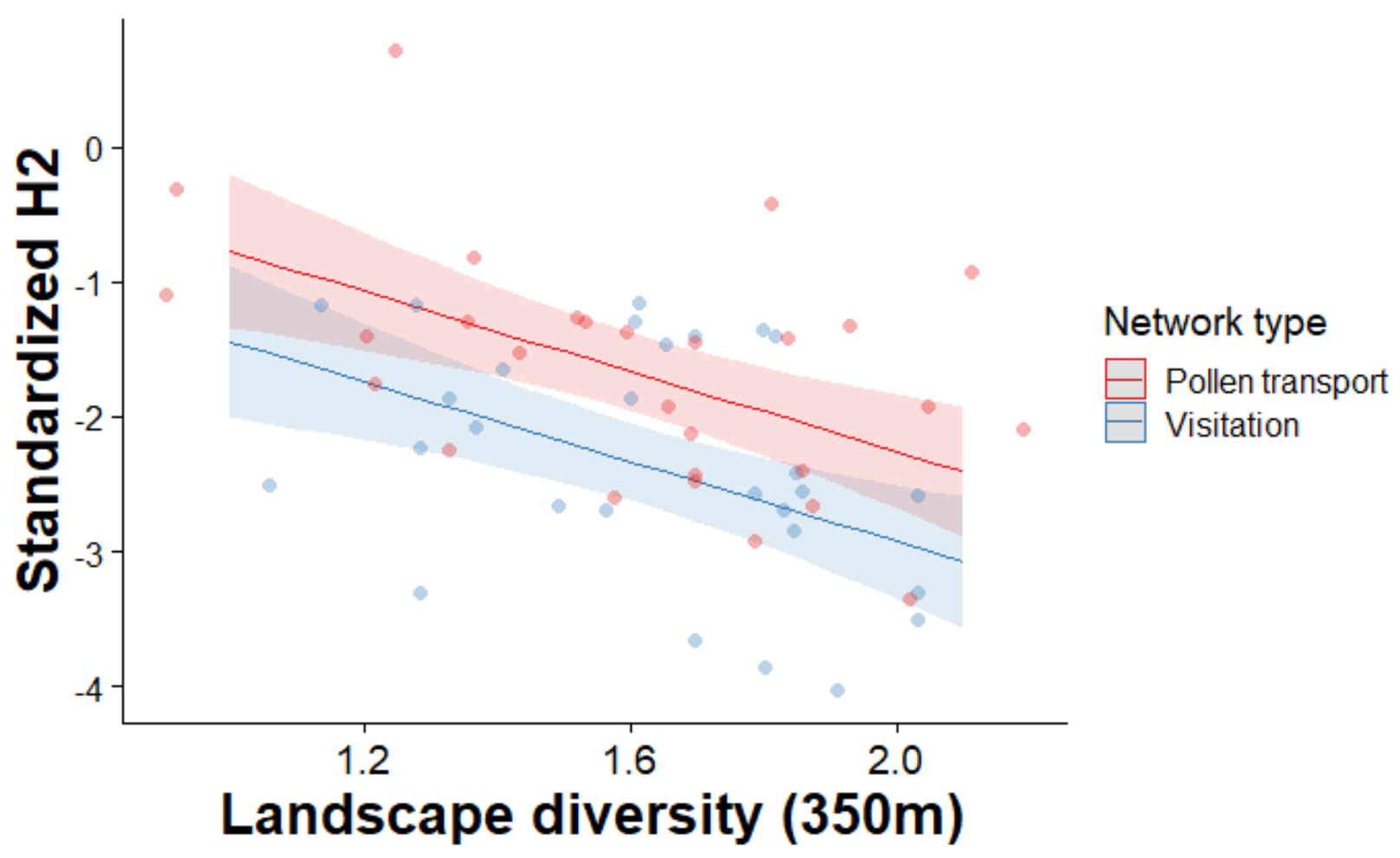

Figure 2. Relationship between standardized network specialization (H2), network type and landscape diversity (i.e. Shannon diversity of land cover types). Each network type includes 28 local networks (fragments) in each dataset (pollen transport and visitation). Bands represent 95\% confidence intervals.

At the metanetwork level, we found a total of 345 unique combinations of plant-pollinator interactions considering both visitation and pollen transport metanetworks, from which 127 $(36.8 \%$ ) were found in both types (Fig. 3, Table S5). From a total of 222 unique pairwise interactions detected in the pollen transport metanetwork, $95(42.8 \%)$ were exclusive to it (i.e. they were not registered in the visitation metanetwork, Table S6) and 123 out of 250 (49.2\%) were recorded only in the visitation metanetwork (Table S7). Furthermore, we identified important differences in the number of interactions established by some plant species in both metanetworks (Table S8 and Table S9). The most outstanding case was Knautia arvensis (Caprifoliaceae), which was visited by 19 different bees but only four of them transported its pollen. 


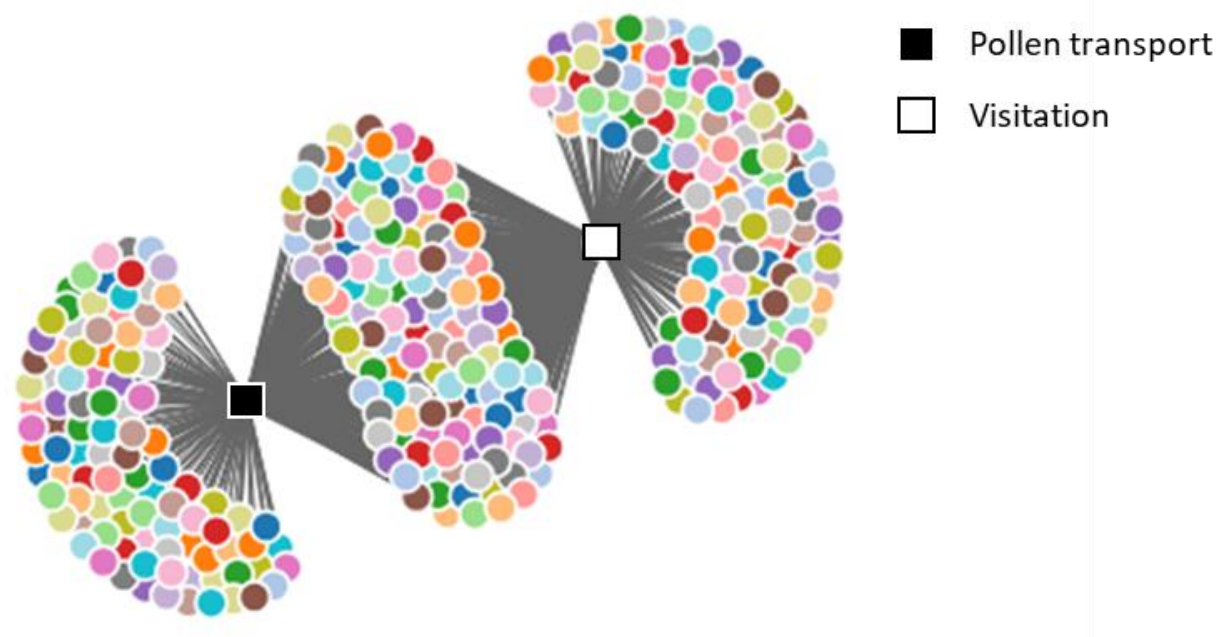

Figure 3. Diagram representation of the plant-pollinator interactions (circles) occurring in the pollen transport (black square) and visitation (white square) metanetworks. Those interactions exclusive to the pollen transport dataset occur to the left side of the black square and those exclusive to the visitation dataset are shown to the right side of the white square. Circles in between squares represent unique pairwise interactions occurring in both datasets.

Eight out of the 10 most central plant species in the visitation and pollen transport metanetworks, based on the proportional generality of the species, coincided (Fig. 4). The most central plant species in the visitation metanetwork, Knautia arvensis, did not fall among the ten most central plant species in the pollen transport metanetwork. On the other hand, Trifolium pratense, the most central plant species in the pollen transport network, only showed up at the sixth place in the visitation metanetwork. Moreover, centrality measures based on weighted betweenness differed from those based on proportional generality in both metanetworks. Centaurea scabiosa and Hippocrepis comosa, two habitat specialist plants, were consistently the two with the highest weighted betweenness in both metanetworks (Fig. 4). 
a)

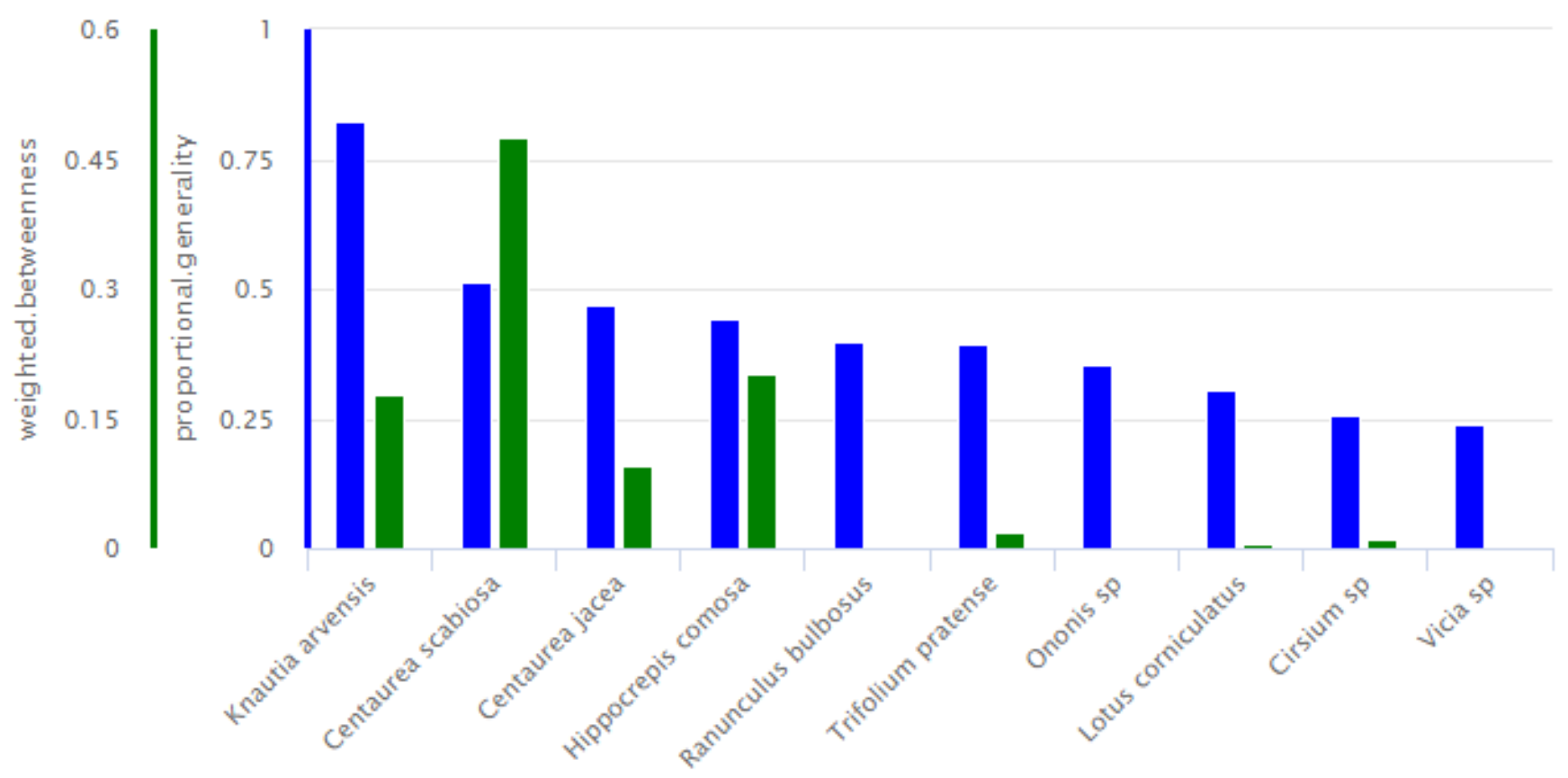

b)

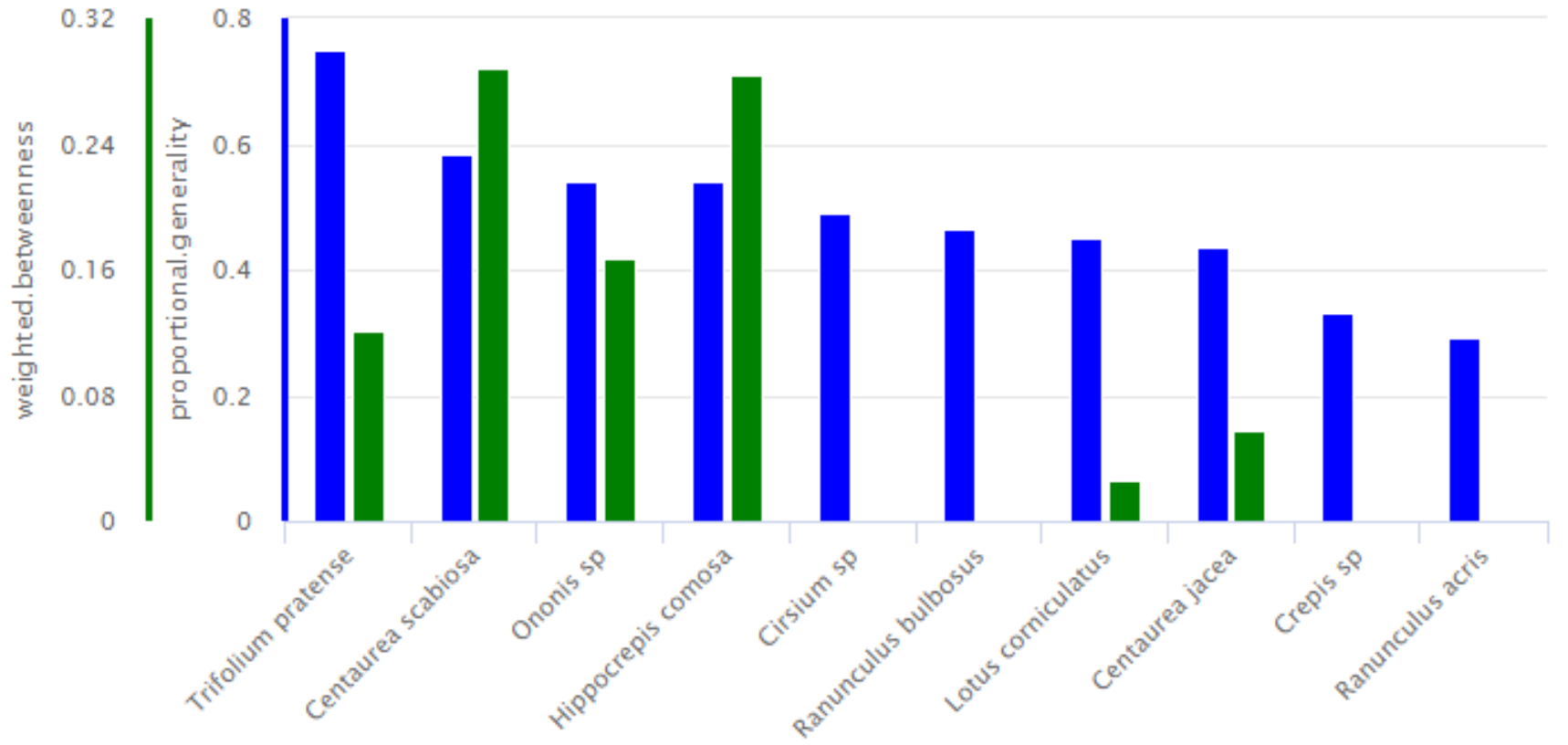

Figure 4. The ten most central plant species based on proportional generality in a) the visitation metanetwork and b) the pollen transport metanetwork.

Further, we found that the probability of the presence of an interaction in both datasets (i.e. visitation and pollen transport) was affected by the plant habitat specialization and the pollinator 
identity. Specifically, interactions involving habitat specialist plants $\left(X^{2}=6.47, P=0.011\right)$ and bumblebees $\left(\mathrm{X}^{2}=17.24, \mathrm{P}=0.0071\right)$, had a significantly higher probability of occurrence in both networks than those involving habitat generalist plants and solitary bees (Fig. 5).

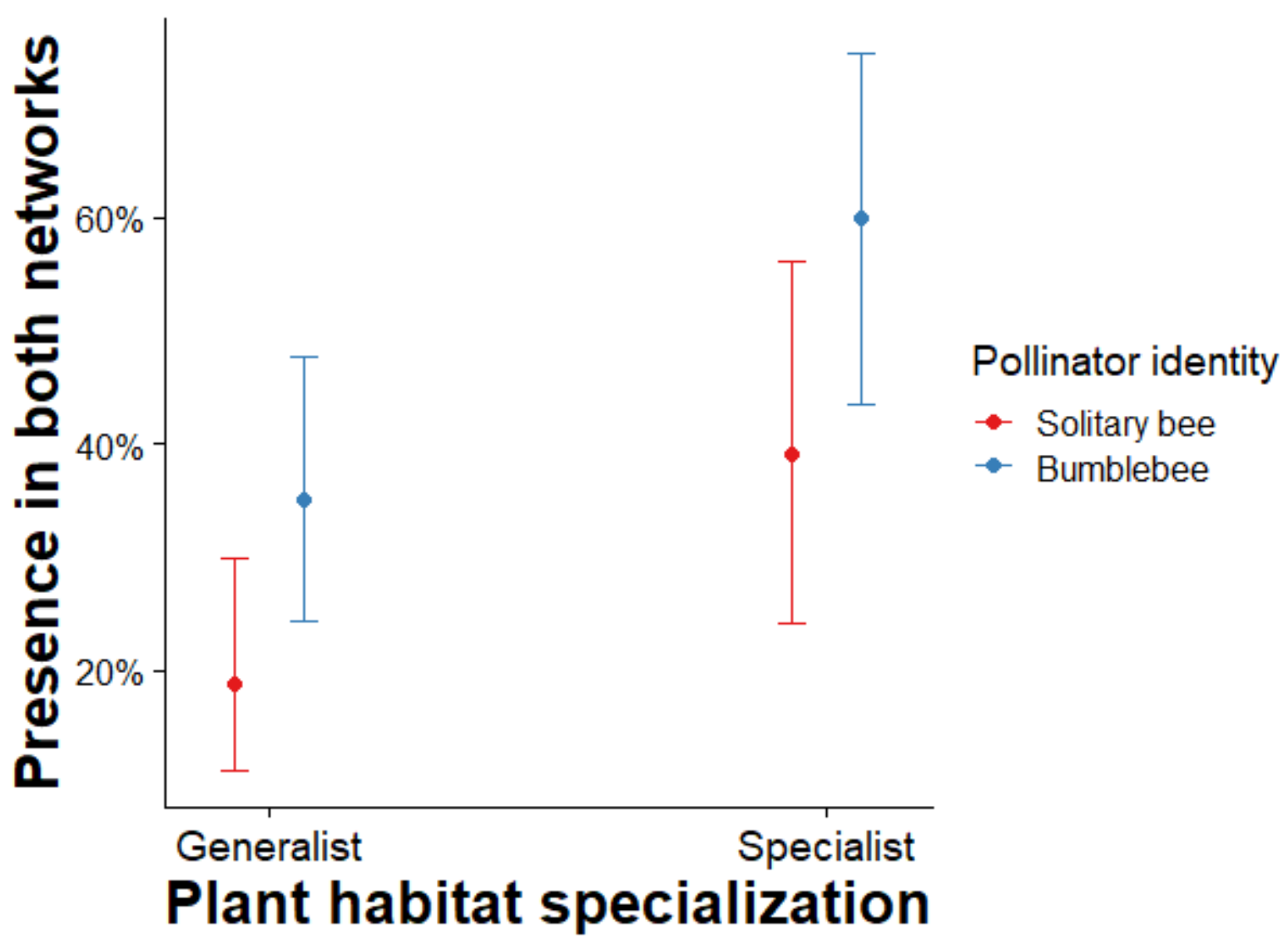

Figure 5. Effects of the plant habitat specialization and the pollinator identity on the probability of presence of an interaction in the visitation and pollen transport datasets simultaneously.

Finally, we found a significant positive effect of landscape diversity on the number of singlefragment interactions (Fig. S2). However, the spatial scale at which this effect was stronger differed for the visitation and pollen transport datasets. Specifically, the number of singlefragment interactions increased with landscape diversity at the $150 \mathrm{~m}$ scale for the visitation data $(\mathrm{X} 2=4.59, \mathrm{P}=0.032$, Fig. S2a) and at the $500 \mathrm{~m}$ scale for the pollen transport data $(\mathrm{X} 2=5.96, \mathrm{P}$ $=0.015$, Fig. S2b). Moreover, landscape diversity at the $500 \mathrm{~m}$ scale was found to significantly increase the proportion of single-fragment interactions $(F=5.26, P=0.030)$. Nonetheless, this effect was only found for the pollen transport data (Fig. 6). Fragment area and fragment 
connectivity had no significant effect on the number of single-fragment interactions or the proportion of single-fragment interactions (Table S10).

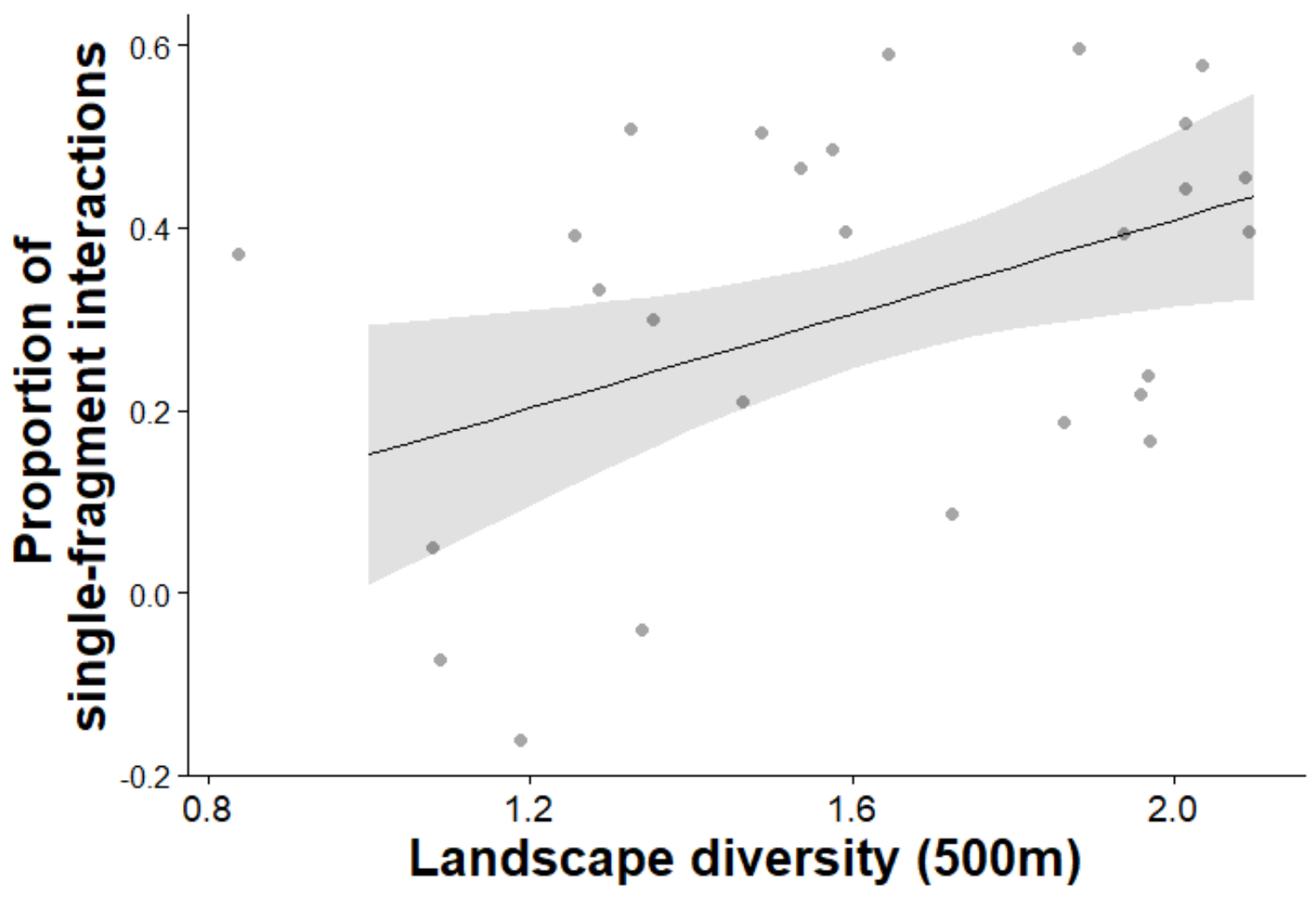

Figure 6. Effect of landscape diversity on the proportion of single-fragment interactions occurring in local networks based on the pollen transport dataset.

\section{Discussion}

In this study, we compared plant-pollinator networks from flower visitation data with those from pollen transport data across a gradient of habitat fragmentation and we identified their similarities and differences. Of all interactions found, $63.2 \%$ were exclusive to either the visitation or pollen transport networks, highlighting the numerous low-frequency interactions that are not captured by observations of flower visits (27.5\%), and also a high number of interactions $(35.7 \%)$ that do not translate into pollen transport. Pollen transport networks were more specialized than visitation networks. Also, the diversity of land cover types in the surroundings of a habitat fragment increased network generalization. The probability of being represented in both network types was larger for interactions involving habitat specialist plants and bumblebees, compared to those involving habitat generalist plants and solitary bees. Lastly, we found a positive effect of 
landscape diversity on the number of single-fragment interactions in the pollen transport and visitation networks as well as on the proportion of single-fragment interactions, which was found exclusively in the pollen transport dataset.

\section{Network type and landscape diversity effects on network specialization}

As expected, pollen transport networks were found to be more specialized than visitation networks (Fig. 2). This pattern supports previous studies (Alarcón, 2010; Zhao et al., 2019) and shows that many flower visits do not translate into pollen transport (King et al., 2013). Importantly, a higher specialization of pollen transport networks indicates that pollination networks might be more vulnerable to collapse following disturbance, as increased specialization can make networks less robust and more prone to co-extinction cascades (Classen et al., 2020; Thébault and Fontaine, 2010; Vanbergen et al., 2017, but see Benadi et al., 2013; Hoiss et al., 2015). The vast majority of plant-pollinator network studies are based on visitation data and conclusions regarding biodiversity conservation and ecosystem services provision are derived mostly from them. In light of our results, we call attention to the risk of an overestimation of plant-pollinator networks stability and robustness in past studies based solely on flower visitation data.

Landscape diversity had a negative effect on network specialization, i.e. plant-pollinator networks from fragments surrounded by a higher diversity of land cover types were more generalized. Plant-pollinator networks specialization has been shown to be affected by many variables, such as species richness and species behavior (Classen et al., 2020; Hoiss et al., 2015; Jauker et al., 2019). Analyzing plant-pollinator interactions in calcareous grasslands, Jauker et al., 2019, found that decreasing fragment size reduced networks generalization through the loss of species and interactions. Similarly to habitat fragmentation, landscape simplification may decrease the availability of interacting partners as a consequence of reduced population sizes or local extinctions. The absence of interacting partners can have opposite effects on species specialization. On the one hand, pollinators may visit more plant species to compensate for missing resources, therefore increasing their generalization (Brosi and Briggs, 2013). However, in case of limited behavioral plasticity or high plant fidelity, specialization could increase after disturbance (i.e. loss of a plant partner) as pollinators would be unable to establish new interactions. For plants, losing a pollinator may directly increase plant specialization by reducing 
the number of interacting partners. Nonetheless, reduced competition for resources among pollinators could facilitate visitation from opportunistic (and usually less effective) pollinators, therefore increasing the plant generalization (Brosi and Briggs, 2013). Our results suggest that pollinators may not compensate for the missing plant partners and that plants do not get extra visits once a specialized pollinator is lost following landscape homogenization.

\section{Visitation and pollen transport exclusive interactions}

We found a high amount of interactions occurring exclusively in the pollen transport (27.5\%) or visitation datasets (35.7\%, Fig. 3). Plant-pollinator networks based on pollen transport and pollen transfer data were recently found to have topological differences compared to traditional networks based on flower visitation (Emer et al., 2015; Zhao et al., 2019). This suggests that conclusions derived from traditional studies may have to be revisited. Our results indicate that the structural differences between visitation and pollen transport networks could be larger than previously believed, based on the surprisingly high amount of interactions found exclusively in the visitation and pollen transport datasets. These results challenge the so far accepted assumption that visitation data is a sufficient surrogate of animal mediated pollen transport.

The large presence of flower visitors with a relatively small capacity for pollen transport raises many questions regarding their importance for pollination (Moquet et al., 2017). In theory, deposition of a single conspecific pollen grain could be enough for pollination to occur, but pollen deposition thresholds are common given that not all pollen deposited by pollinators is viable ( $\mathrm{Li}$ et al., 2019). Therefore, a relatively high amount of conspecific pollen deposition is usually needed for a meaningful pollination success ( $\mathrm{Li}$ et al., 2019). The concomitant deposition of heterospecific pollen is also an important factor considering its negative effects on pollination (Arceo-Gómez and Ashman, 2011; Brown and Mitchell, 2001). Actually, from a plant species perspective, a strategy based on maximizing pollinators' visits might come at the cost of high heterospecific pollen deposition on their stigmas. Contrastingly, a strategy based on the attraction of a small number of specialized pollinators (and therefore larger potential for conspecific pollen deposition) comes at the cost of a higher dependence on a small group of pollinators and a lower probability of visitation. Habitat fragmentation and landscape homogenization may impose a reduced set of pollinator partners to interact with. As a consequence, higher plant specialization 
could arise as an indirect result of the lack of alternative partners and not as part of an ecological strategy to increase reproductive success.

The pollen transport networks revealed a high amount of rare interactions. This implies that plant-pollinator networks based only on flower visitation data are not just biased by the inclusion of interactions with no potential for pollination, but also by missing many rare interactions. Consequently, pollen loads analysis represents a better approach to study pollination systems, as the actual pollen dispersal across the plant community can be quantified. Visitation data, on the other hand, appears fundamental to understand the plant-pollinator interactions from the pollinator perspective, as competition among pollinators and the different foraging strategies that pollinators use to maximize their fitness can be eventually quantified.

The detection of interactions involving rare habitat specialist plants, such as Scabiosa columbaria (Angeloni et al., 2014; Bijlsma et al., 1994), indicates that pollen load analyses can contribute to improve conservation strategies by identifying remaining small populations of these rare species. For example, restoration efforts targeting these small populations could be undertaken in places where the plants were thought to be locally extinct. Then again, the high amount of interactions not translating into pollen transport might suggest a higher vulnerability of plant-pollinator networks to the loss of species.

\section{Plant habitat specialization and pollinator identity on interaction presence probability}

As predicted, interactions involving bumblebees had a higher probability of occurrence in both, the visitation and pollen transport networks (Fig. 5). Bumblebee species are bigger than most solitary bees, have dense hair and also the capacity to vibrate their bodies through thoracic muscle contractions to extract pollen from buzz pollinated plants (Stavert et al., 2016; VallejoMarín, 2019). These morphological and behavioral traits, in addition to their abundance, give bumblebees a high capacity for pollen transport (Velthuis and van Doorn, 2006; Willmer et al., 1994). Our results support this by demonstrating that the probability of a bumblebee carrying pollen after a flower visit is higher than that of solitary bees. However, studies on pollen transfer (i.e. pollen deposition in a conspecific stigma) after flower visits would be necessary to verify whether bumblebees are also able to deposit more pollen on stigmas than solitary bees, since pollen transport does not always translate into pollen deposition (Emer et al., 2015). Furthermore, the ratio between conspecific and heterospecific pollen deposition might also be important to 
analyze, as it is essential for plants' reproductive success (Arceo-Gómez and Ashman, 2011; Morales and Traveset, 2008).

We found a smaller representation of habitat generalist plants on pollen transport networks compared to habitat specialist ones (Fig. 5). The direct consequence of this result is that flower visits to habitat specialist plants have a higher probability to translate into pollen transport than visits to habitat generalist plants. A higher representation of habitat specialist plants in pollen transport networks cannot be solely related to a higher attractiveness of habitat specialist flowers or pollen, as interactions involving habitat specialist plants in the pollen transport dataset were less than half of the total interactions found (46.8\%). This result is rather a consequence of different mechanisms that allow habitat specialist plants to allocate their pollen more frequently on flower visitors than habitat generalists. Habitat specialist plants are expected to have a long history of evolutionary adaptations to the local pollinator pool and, therefore, to have developed mechanisms for efficient pollen transport through those pollinators (Miller-Struttmann, 2013). Conversely, generalist plants should lack such adaptations as they would exhibit more opportunistic strategies to quickly adapt to different environments. The adaptations of plants to increase pollination success can occur at many levels including pollen vector attraction, pollen presentation, pollen transport and pollen germination (Minnaar et al., 2019). At the visitation level, traits such as flower size, flower abundance and the quantity and quality of offered flower rewards (i.e. pollen and nectar), may increase visitation rates (Conner and Rush, 1996). At the pollen transport level, plants may possess mechanisms to place larger amounts of pollen at specific places of the flower visitors' body (Minnaar et al., 2019). At the pollen transfer level, plant traits such as the stigma type (i.e. wet or dry), pollen morphological traits or behavioral characteristics of pollinators may affect the quantity and quality of pollen deposition (Emer et al., 2015; Konzmann et al., 2019; Minnaar et al., 2019). Even after pollen deposition on stigmas, plants may exhibit mechanisms to regulate receptiveness depending on the characteristics of the flower visitor (Betts et al., 2015).

\section{Plant and pollinator metanetwork hubs}

Interestingly, seven out of the 10 most central pollinator species and eight out of the 10 most central plant species were shared between the visitation and pollen transport data, indicating that the most central species tend to be identical in both metanetworks (Fig. 4 and Fig. S1). In 
addition, six out of the 10 most central plant species were habitat specialist in both metaneworks, but only one pollinator species (Andrena subopaca and Halictus scabiosae in the visitation and pollen transport metanetworks, respectively) was a habitat specialist among the most central pollinator species in both metanetworks. These results reveal that the most central species in the metanetworks are asymmetric in terms of habitat specialization, implying that habitat specialists tend to interact with habitat generalist species. This is in agreement with previous findings of pollination networks in grasslands communities (Fantinato et al., 2019). Remarkably, the habitat generalist Knautia arvesis, the most central plant in the visitation metanetwork, was not included among the 10 most central plant species in the pollen transport metanetwork. This highlights how misleading it can be to draw conclusions on pollination dynamics based exclusively on flower visitation data. It is also important to highlight the presence of Osmia bicolor as the only solitary bee species representative in the group of most central pollinators in both metanetwork types. Furthermore, $O$. bicolor exhibited the third highest weighted betweenness in both datasets among all bee species (i.e. including bumblebees). This is an exceptional trait for a solitary bee species, considering that bumblebees are frequently considered the dominant pollinator group given their high abundance and large body size (Gorenflo et al., 2017; Willmer et al., 2017).

\section{Pollinator identity}

Our results support the hypothesis that visitation data is a poor predictor of a pollinator's ability to transport pollen, as the presence of a plant's pollen in transport networks does not necessarily correlate to how frequently visited that plant is (King et al., 2013). The habitat generalist Knautia arvensis, for example, was visited by many species of both bee guilds (bumblebees and solitary bees) being involved in a total of 105 interactions events. As a consequence, this plant exhibited

the highest proportional generality in the visitation metanetwork. However, we found only ten interactions with $K$. arvensis in the pollen transport networks, involving only four bumblebee species and no solitary bees (Table S8 and Table S9). In contrast, the habitat specialist, Onobrychis viciifolia, got its pollen transported by all its seven species of visitors from both guilds (Table S8 and Table S9).

Solitary bees were fundamental for the pollen transport of many plant species. In particular, they transported pollen of 16 habitat specialist plants and were the only pollen vector of at least three of them (Table S3). Considering that many solitary bee species are vulnerable and threatened 
with extinction (Jauker et al., 2013; Nieto et al., 2017), these results signal to the importance of their role in calcareous grasslands and to the potential risk of their absence for habitat specialist plants reproductive success. Our findings reveal that both, bumblebees and solitary bees, are complementary for pollen transport of calcareous grasslands plant species.

\section{Landscape diversity effect on single-fragment interactions}

The number of single-fragment interactions increased consistently with landscape diversity (Fig. S4). This highlights that a diverse group of land cover types benefits the diversity of interactions, most likely by providing suitable conditions for both, habitat specialist and habitat generalist species. Interestingly, the spatial scale at which landscape diversity most strongly affected the number of unique interactions was larger for the pollen transport dataset compared to the visitation dataset. This suggests that landscape-scale conservation measures to protect plantpollinator networks might be undertaken at the wrong spatial scales when solely based on flower visitation data.

When considering not only the number of single-fragment interactions, but the proportion of single-fragment interactions (i.e. number unique interactions divided by interaction richness), we found a significant positive effect of landscape diversity that was, interestingly, not captured in the visitation dataset (Fig. 6). This means that the increased number of single-fragment interactions is not solely related to a general increase in the total number of interactions with landscape diversification. Importantly, this effect was only captured with the pollen transport data and highlights that landscape structure effects can remain undetected in plant-pollinator studies solely based on visitation data. It also implies that landscape diversification has a disproportionally positive effect on the occurrence of single-fragment interactions compared to the total amount of interactions.

\section{Conclusion}

Here we analyzed plant-pollinator networks across a gradient of habitat fragmentation through data on flower visitation and pollen transport by bees. We found that pollen transport networks were more specialized than visitation networks, indicating that plant-pollinator networks could be more vulnerable than previously believed. Only $35.7 \%$ of the total amount of plant-pollinator interactions registered occurred in both, flower visitation and pollen transport networks. This challenges the widely held assumption that visitation networks are a sufficient surrogate of 
pollination systems. It also questions conclusions drawn from these studies, as the actual properties and dynamics of pollination networks can be strikingly different from current pollination paradigms. We found positive effects of landscape diversity on the proportion of single-fragment interactions for pollen transport, but not visitation networks, highlighting the importance of landscape level measures for the conservation of plant-pollinator networks. Interactions involving habitat specialist plants and bumblebees were significantly more represented in the visitation and pollen transport networks than interactions involving habitat generalist plants and solitary bees. Nonetheless, the pollen of several plant species was found to be only transported by solitary bees and we identified solitary bee species with disproportionally high importance for the metacommunity. Our study shows that conservation of pollination systems and related pollination services cannot be conceived without finer data on the biological processes underlying plant-pollinator interaction networks, such as pollen load analyses. Our results have important consequences for the understanding of the responses of plant-pollinator networks to habitat fragmentation and contribute to unveil important processes underpinning the dynamics of these networks.

\section{Acknowledgments}

This research was supported by the German Research Association (DFG) Research Training Group 1644 "Scaling Problems in Statistics", grant no. 152112243. Our gratitude goes also to all assistants that contributed to data collection and pollen analyses with great dedication.

\section{References}

Alarcón R. Congruence between visitation and pollen-transport networks in a California plantpollinator community. Oikos 2010;119(1):35-44.

Angeloni F, Vergeer P, Wagemaker CAM, Ouborg NJ. Within and between population variation in inbreeding depression in the locally threatened perennial Scabiosa columbaria. Conserv Genet 2014;15(2):331-42.

Arceo-Gómez G, Ashman T-L. Heterospecific pollen deposition: does diversity alter the consequences? The New phytologist 2011;192(3):738-46.

Aslan CE. Implications of non-native species for mutualistic network resistance and resilience. PloS one 2019;14(6):0217498. 
Ballantyne G, Baldock KCR, Willmer PG. Constructing more informative plant-pollinator networks: visitation and pollen deposition networks in a heathland plant community. Proceedings. Biological sciences 2015;282(1814).

Benadi G, Blüthgen N, Hovestadt T, Poethke H-J. Contrasting specialization-stability relationships in plant-animal mutualistic systems. Ecological Modelling 2013;258:65-73.

Betts MG, Hadley AS, Kress WJ. Pollinator recognition by a keystone tropical plant. Proceedings of the National Academy of Sciences of the United States of America 2015;112(11):3433-8.

Bijlsma R, Ouborg NJ, Treuren R. On genetic erosion and population extinction in plants: A case study in Scabiosa columbaria and Salvia pratensis. In: Loeschcke V, Jain SK, Tomiuk J, editors. Conservation genetics. [Place of publication not identified]: Springer Basel; 1994. p. 255-271.

Blüthgen N, Menzel F, Blüthgen N. Measuring specialization in species interaction networks. BMC Ecology 2006;6:9.

Bosch J, González AMM, Rodrigo A, Navarro D. Plant-pollinator networks: adding the pollinator's perspective. Ecology letters 2009;12(5):409-19.

Brosi BJ, Briggs HM. Single pollinator species losses reduce floral fidelity and plant reproductive function. Proceedings of the National Academy of Sciences of the United States of America 2013;110(32):13044-8.

Brown BJ, Mitchell RJ. Competition for pollination: effects of pollen of an invasive plant on seed set of a native congener. Oecologia 2001;129(1):43-9.

Classen A, Eardley CD, Hemp A, Peters MK, Peters RS, Ssymank A et al. Specialization of plant-pollinator interactions increases with temperature at Mt. Kilimanjaro. Ecol Evol 2020;10(4):2182-95.

Conner JK, Rush S. Effects of flower size and number on pollinator visitation to wild radish, Raphanus raphanistrum. Oecologia 1996;105(4):509-16.

Dafni A. Pollination ecology: a practical approach: Oxford University Press; 1992.

Domínguez-García V, Muñoz MA. Ranking species in mutualistic networks. Scientific reports 2015;5:8182.

Dormann CF, Fründ J, Blüthgen N, Gruber B. Indices, graphs and null models: analyzing bipartite ecological networks. The Open Ecology Journal 2009;2(1).

Dormann CF, Gruber B, Fründ J. Introducing the bipartite package: analysing ecological networks. interaction 2008;1(0.2413793). 
Dormann CF, Strauss R. Detecting modules in quantitative bipartite networks: The QuaBiMo algorithm. Methods Ecol Evol 2014;5(1):90-8. http://arxiv.org/pdf/1304.3218v1.

Emer C, Memmott J, Vaughan IP, Montoya D, Tylianakis JM. Species roles in plant-pollinator communities are conserved across native and alien ranges. Diversity and Distributions 2016;22(8):841-52.

Emer C, Vaughan IP, Hiscock S, Memmott J. The Impact of the Invasive Alien Plant, Impatiens glandulifera, on Pollen Transfer Networks. PloS ONE 2015;10(12):e0143532.

Fantinato E, Del Vecchio S, Buffa G. The co-occurrence of different grassland communities increases the stability of pollination networks. Flora 2019;255:11-7.

Freitas L. Concepts of pollinator performance: is a simple approach necessary to achieve a standardized terminology? Braz. J. Bot 2013;36(1):3-8.

Gathmann A, Tscharntke T. Foraging ranges of solitary bees. Journal of Animal Ecology 2002;71(5):757-64.

Genini J, Morellato LPC, Guimarães PR, Olesen JM. Cheaters in mutualism networks. Biology Letters 2010;6(4):494-7.

González AMM, Dalsgaard B, Olesen JM. Centrality measures and the importance of generalist species in pollination networks. Ecological Complexity 2010;7(1):36-43.

González AMM, Ornelas JF, Dalsgaard B, Márquez-Luna U, Lara C. Meta-networks for the study of biogeographical traits in ecological networks: the Mexican hummingbird-plant assemblage. The Science of Nature 2018;105(9-10):54.

Gorenflo A, Diekötter T, van Kleunen M, Wolters V, Jauker F. Contrasting pollination efficiency and effectiveness among flower visitors of Malva sylvestris, Borago officinalis and Onobrychis viciifolia. Journal of pollination Ecology 2017;21(1):62-70.

Grass I, Jauker B, Steffan-Dewenter I, Tscharntke T, Jauker F. Past and potential future effects of habitat fragmentation on structure and stability of plant-pollinator and host-parasitoid networks. Nature Ecology \& Evolution 2018;2(9):1408-17.

Gresty CEA, Clare E, Devey DS, Cowan RS, Csiba L, Malakasi P et al. Flower preferences and pollen transport networks for cavity-nesting solitary bees: Implications for the design of agri-environment schemes. Ecology and evolution 2018;8(15):7574-87.

Habel JC, Dengler J, Janisova M, Toeroek P, Wellstein C, Wiezik M. European grassland ecosystems: Threatened hotspots of biodiversity. Biodiversity and Conservation 2013;22(10):2131-8. 
Hagen M, Kissling WD, Rasmussen C, Am Aguiar M de, Brown LE, Carstensen DW et al. Biodiversity, species interactions and ecological networks in a fragmented world. In: Advances in ecological research: Elsevier; 2012. p. 89-210.

Hanski I, Kuussaari M, Nieminen M. Metapopulation structure and migration in the butterfly Melitaea cinxia. Ecology 1994;75(3):747-62.

Hesselbarth MHK, Sciaini M, With KA, Wiegand K, Nowosad J. landscapemetrics an opensource R tool to calculate landscape metrics. Ecography 2019;42(10):1648-57.

Hoiss B, Krauss J, Steffan-Dewenter I. Interactive effects of elevation, species richness and extreme climatic events on plant-pollinator networks. Global change biology 2015;21(11):4086-97.

Hopfenmüller S, Steffan-Dewenter I, Holzschuh A. Trait-specific responses of wild bee communities to landscape composition, configuration and local factors. PloS one 2014;9(8):e104439.

Jauker B, Krauss J, Jauker F, Steffan-Dewenter I. Linking life history traits to pollinator loss in fragmented calcareous grasslands. Landscape Ecol 2013;28(1):107-20.

Jauker F, Jauker B, Grass I, Steffan-Dewenter I, Wolters V. Partitioning wild bee and hoverfly contributions to plant-pollinator network structure in fragmented habitats. Ecology 2019;100(2):e02569.

Jones GD. Pollen analyses for pollination research, acetolysis. Journal of pollination Ecology 2014;13(21):203-17.

Jordán F. Keystone species and food webs. Philosophical transactions of the Royal Society of London. Series B, Biological sciences 2009;364(1524):1733-41.

Kaiser-Bunbury CN, Muff S, Memmott J, Müller CB, Caflisch A. The robustness of pollination networks to the loss of species and interactions: a quantitative approach incorporating pollinator behaviour. Ecology letters 2010;13(4):442-52.

King C, Ballantyne G, Willmer PG. Why flower visitation is a poor proxy for pollination: measuring single-visit pollen deposition, with implications for pollination networks and conservation. Methods Ecol Evol 2013;4(9):811-8.

Konzmann S, Koethe S, Lunau K. Pollen grain morphology is not exclusively responsible for pollen collectability in bumble bees. Scientific reports 2019;9(1):4705.

Krauss J, Steffan-Dewenter I, Tscharntke T. How does landscape context contribute to effects of habitat fragmentation on diversity and population density of butterflies? J Biogeography 2003;30(6):889-900. 
Li K, Tscharntke T, Saintes B, Buchori D, Grass I. Critical factors limiting pollination success in oil palm: A systematic review. Agriculture, Ecosystems \& Environment 2019;280:15260.

Lopezaraiza-Mikel ME, Hayes RB, Whalley MR, Memmott J. The impact of an alien plant on a native plant-pollinator network: an experimental approach. Ecology letters 2007;10(7):539-50.

MacInnis G, Forrest JRK. Pollination by wild bees yields larger strawberries than pollination by honey bees. J Appl Ecol 2019;56(4):824-32.

Miller-Struttmann NE. Rarity and reproductive biology: habitat specialists reveal a complex relationship. Botany 2013;91(6):349-59.

Moquet L, Bruyère L, Pirard B, Jacquemart A-L. Nectar foragers contribute to the pollination of buzz-pollinated plant species. American journal of botany 2017;104(10):1451-63.

Morales CL, Traveset A. Interspecific Pollen Transfer: Magnitude, Prevalence and Consequences for Plant Fitness. Critical Reviews in Plant Sciences 2008;27(4):221-38.

Morán-López T, Espíndola WD, Vizzachero BS, Fontanella A, Salinas L, Arana C et al. Can network metrics predict vulnerability and species roles in bird-dispersed plant communities? Not without behaviour. Ecology letters 2020.

Nieto A, Roberts SPM, Kemp J, Rasmont P, Kuhlmann M, Criado MG et al. European red list of bees 2017.

Pilosof S, Porter MA, Pascual M, Kéfi S. The multilayer nature of ecological networks. Nature Ecology \& Evolution 2017;1(4):101.

Piqueray J, Bisteau E, Cristofoli S, Palm R, Poschlod P, Mahy G. Plant species extinction debt in a temperate biodiversity hotspot: Community, species and functional traits approaches. Biological Conservation 2011;144(5):1619-29.

Stavert JR, Liñán-Cembrano G, Beggs JR, Howlett BG, Pattemore DE, Bartomeus I. Hairiness: the missing link between pollinators and pollination. PeerJ 2016;4:e2779.

Thébault E, Fontaine C. Stability of ecological communities and the architecture of mutualistic and trophic networks. Science (New York, N.Y.) 2010;329(5993):853-6.

van Swaay CAM, Brereton T, Kirkland P, Warren MS. Manual for butterfly monitoring. Report VS2012 2012;10.

Vanbergen AJ, Woodcock BA, Heard MS, Chapman DS. Network size, structure and mutualism dependence affect the propensity for plant-pollinator extinction cascades. Funct Ecol 2017;31(6):1285-93. 
Velthuis HHW, van Doorn A. A century of advances in bumblebee domestication and the economic and environmental aspects of its commercialization for pollination. Apidologie 2006;37(4):421-51.

Vieira MC, Almeida-Neto M. A simple stochastic model for complex coextinctions in mutualistic networks: robustness decreases with connectance. Ecology letters 2015;18(2):144-52.

Westphal C, Steffan-Dewenter I, Tscharntke T. Bumblebees experience landscapes at different spatial scales: possible implications for coexistence. Oecologia 2006;149(2):289-300.

Westrich P. Die Wildbienen Deutschlands: Verlag Eugen Ulmer; 2018.

Willmer PG, BATAW AAM, HUGHES JP. The superiority of bumblebees to honeybees as pollinators: insect visits to raspberry flowers. Ecol Entomol 1994;19(3):271-84.

Willmer PG, Cunnold H, Ballantyne G. Insights from measuring pollen deposition: quantifying the pre-eminence of bees as flower visitors and effective pollinators. Arthropod-Plant Interactions 2017;11(3):411-25.

Xiao Y, Li X, Cao Y, Dong M. The diverse effects of habitat fragmentation on plant-pollinator interactions. Plant Ecology 2016;217(7):857-68.

Zhao Y-H, Lázaro A, Ren Z-X, Zhou W, Li H-D, Tao Z-B et al. The topological differences between visitation and pollen transport networks: a comparison in species rich communities of the Himalaya-Hengduan Mountains. Oikos 2019;128(4):551-62. 


\section{Supplementary material}

Connectivity index based on Hanski et al. 1994

$$
I=\sum e^{-d i j} A_{j}
$$

$\mathrm{Aj}$ is the size in $\mathrm{m}^{2}$ of neighbouring calcareous grasslands and dij is the distance in $\mathrm{km}$ from the neighbouring grassland $\mathrm{j}$ to the study site I (following Krauss et al. 2004). The $2 \mathrm{~km}$ radius was chosen to capture the maximum biologically meaningful distance for the largest pollinators (see also Krauss et al. 2010). Larger values of "I" indicate higher connectivity (Table S1).

Table S1. Landscape metrics for each study site: Area in $\mathrm{m}^{2}$, management, Shannon diversity index of cover types in a $200 \mathrm{~m}$ radius and connectivity index.

\begin{tabular}{|c|c|c|c|c|}
\hline Study site & $\begin{array}{c}\text { Habitat area } \\
\left(\mathrm{m}^{2}\right)\end{array}$ & Management & $\begin{array}{c}\text { Shannon index } \\
(200 \mathrm{~m})\end{array}$ & $\begin{array}{c}\text { Connectivity } \\
\text { index }\end{array}$ \\
\hline Huhnsberg & 52557 & Grazing & 1.50 & 52162 \\
\hline Mühlenberg & 50673 & Grazing & 1.89 & 15805 \\
\hline Aschenburg & 35479 & Grazing & 1.45 & 19917 \\
\hline Ellershagen & 33186 & Grazing & 0.68 & 7145 \\
\hline Lengender Burg & 16804 & Unmanaged & 1.68 & 4914 \\
\hline Dehnerberg & 12724 & Grazing & 1.85 & 3671 \\
\hline Mackenrodt & 11612 & Mowing & 1.71 & 637 \\
\hline Burgbreite & 7641 & Grazing & 1.28 & 7335 \\
\hline Gladeberg & 7288 & Grazing & 1.19 & 3814 \\
\hline Weinberg & 6641 & Grazing & 1.71 & 25941 \\
\hline Hackelberg & 5823 & Mowing & 1.58 & 28463 \\
\hline Am Graben & 5535 & Unmanaged & 1.93 & 1186 \\
\hline Tiefetal & 4132 & Grazing & 1.36 & 4617 \\
\hline Südlicher Riesenberg & 3535 & Unmanaged & 1.76 & 6103 \\
\hline Ossenfelder Bahndamm & 3504 & Grazing & 1.86 & 1111 \\
\hline
\end{tabular}




\begin{tabular}{|c|c|c|c|c|}
\hline Kleiner Knull & 3467 & Grazing & 1.55 & 8083 \\
\hline Kuhberg & 3465 & Grazing & 1.78 & 10797 \\
\hline Eschenberg & 1861 & Unmanaged & 1.36 & 306 \\
\hline Vor dem roten Berge & 1462 & Unmanaged & 1.23 & 21676 \\
\hline Auf dem Klee & 778 & Unmanaged & 1.45 & 25575 \\
\hline Schweineberg & 701 & Mowing & 1.70 & 114 \\
\hline Am Hopfenberge & 693 & Unmanaged & 1.34 & 19917 \\
\hline Unter den Niederwiesen & 406 & Mowing & 0.49 & 5332 \\
\hline Emme & 381 & Unmanaged & 0.85 & 10015 \\
\hline Gieseberg Süd & 353 & Unmanaged & 1.71 & 15953 \\
\hline Mühlenberg 2 & 228 & Mowing & 1.12 & 47366 \\
\hline Zipfel am Lindenberg & 227 & Unmanaged & 1.37 & 10518 \\
\hline Lieseberg & 144 & Unmanaged & 1.24 & 2943 \\
\hline Heikenrott & 82 & Mowing & 1.28 & 6152 \\
\hline
\end{tabular}


Table S2. Number of interactions per pollinator group in the visitation data

\begin{tabular}{|c|c|c|}
\hline Plant & Bumblebee & Solitary bee \\
\hline Ajuga reptans & 5 & 0 \\
\hline Alliaria petiolata & 0 & 1 \\
\hline Anemone sylvestris & 3 & 0 \\
\hline Anthyllis vulneraria & 11 & 0 \\
\hline Aquilegia vulgaris & 10 & 1 \\
\hline Astragalus glycyphyllos & 1 & 0 \\
\hline Campanula sp & 4 & 0 \\
\hline Carduus nutans & 2 & 0 \\
\hline Carlina vulgaris & 21 & 0 \\
\hline Centaurea jacea & 52 & 51 \\
\hline Centaurea scabiosa & 285 & 32 \\
\hline Cerastium arvense & 1 & 0 \\
\hline Cerinthe minor & 2 & 0 \\
\hline Cirsium sp & 22 & 2 \\
\hline Cirsium vulgare & 2 & 0 \\
\hline Clinopodium acinos & 2 & 0 \\
\hline Clinopodium vulgare & 1 & 0 \\
\hline Cotoneaster integerrimus & 17 & 1 \\
\hline Crataegus monogyna & 2 & 1 \\
\hline Crepis sp & 0 & 2 \\
\hline Dactylorhiza fuchsii & 1 & 0 \\
\hline Daucus carota & 5 & 0 \\
\hline Dictamnus albus & 2 & 0 \\
\hline Echium vulgare & 4 & 0 \\
\hline Euphorbia cyparissias & 0 & 3 \\
\hline Filipendula vulgaris & 0 & 1 \\
\hline Fragaria vesca & 0 & 16 \\
\hline Genista tinctoria & 7 & 5 \\
\hline Geum urbanum & 0 & 1 \\
\hline Helianthemum nummularium & 4 & 2 \\
\hline Hieracium cymosum & 1 & 0 \\
\hline Hieracium lachenalii & 0 & 1 \\
\hline
\end{tabular}




\begin{tabular}{|c|c|c|}
\hline Plant & Bumblebee & Solitary bee \\
\hline Hieracium murorum & 1 & 0 \\
\hline Hieracium pilosella & 0 & 4 \\
\hline Hieracium umbellatum & 2 & 0 \\
\hline Hippocrepis comosa & 100 & 37 \\
\hline Hypericum perforatum & 2 & 0 \\
\hline Knautia arvensis & 105 & 25 \\
\hline Lathyrus sylvestris & 0 & 1 \\
\hline Leontodon hispidus & 0 & 2 \\
\hline Leucanthemum vulgare & 1 & 5 \\
\hline Lotus corniculatus & 30 & 6 \\
\hline Medicago falcata & 1 & 0 \\
\hline Medicago lupulina & 0 & 1 \\
\hline Medicago sativa & 1 & 1 \\
\hline Melampyrum arvense & 1 & 0 \\
\hline Myosotis arvensis & 1 & 3 \\
\hline Onobrychis viciifolia & 13 & 2 \\
\hline Ononis sp & 54 & 4 \\
\hline Origanum vulgare & 0 & 8 \\
\hline Orobanche rapum-genistae & 0 & 1 \\
\hline Plantago lanceolata & 1 & 1 \\
\hline Plantago media & 1 & 0 \\
\hline Polygala comosa & 1 & 0 \\
\hline Potentilla sp & 0 & 8 \\
\hline Primula veris & 3 & 19 \\
\hline Prunella grandiflora & 15 & 0 \\
\hline Ranunculus bulbosus & 1 & 16 \\
\hline Ranunculus repens & 0 & 2 \\
\hline Rhinanthus minor & 2 & 0 \\
\hline Salvia pratensis & 10 & 0 \\
\hline Sanguisorba minor & 1 & 0 \\
\hline Senecio sp & 3 & 7 \\
\hline Silene dioica & 1 & 0 \\
\hline Stellaria holostea & 0 & 4 \\
\hline Taraxacum officinale & 0 & 4 \\
\hline
\end{tabular}




\begin{tabular}{lrr}
\hline Plant & Bumblebee & Solitary bee \\
\hline Trifolium pratense & 38 & 0 \\
Trifolium repens & 1 & 0 \\
Veronica austriaca & 4 & 3 \\
Veronica chamaedrys & 1 & 5 \\
Vicia sp & 12 & 2 \\
\hline
\end{tabular}

Table S3. Number of interactions per pollinator group in the pollen transport data

\begin{tabular}{|c|c|c|}
\hline Plant & Bumblebee & Solitary bee \\
\hline Ajuga reptans & 4 & 1 \\
\hline Anthriscus sylvestris & 3 & 0 \\
\hline Anthyllis vulneraria & 2 & 0 \\
\hline Aquilegia vulgaris & 4 & 2 \\
\hline Astragalus glycyphyllos & 7 & 0 \\
\hline Campanula sp & 3 & 2 \\
\hline Carduus nutans & 2 & 0 \\
\hline Carlina vulgaris & 7 & 0 \\
\hline Centaurea jacea & 44 & 11 \\
\hline Centaurea jacobea & 1 & 0 \\
\hline Centaurea scabiosa & 61 & 11 \\
\hline Cerastium arvense & 0 & 1 \\
\hline Cerinthe minor & 4 & 1 \\
\hline Cirsium sp & 20 & 1 \\
\hline Cotoneaster interregimus & 0 & 1 \\
\hline Crepis sp & 4 & 8 \\
\hline Daucus carota & 3 & 0 \\
\hline Echium vulgare & 3 & 0 \\
\hline Filipendula vulgaris & 0 & 1 \\
\hline Fragaria vesca & 2 & 14 \\
\hline Galium $s p$ & 7 & 1 \\
\hline Genista tinctoria & 3 & 2 \\
\hline Geum urbanum & 1 & 1 \\
\hline
\end{tabular}




\begin{tabular}{|c|c|c|}
\hline Plant & Bumblebee & Solitary bee \\
\hline Helianthemum nuтmularium & 3 & 4 \\
\hline Hieracium cymosum & 1 & 0 \\
\hline Hieracium pilosella & 0 & 3 \\
\hline Hippocrepis comosa & 51 & 11 \\
\hline Knautia arvensis & 10 & 0 \\
\hline Leucanthemum vulgare & 0 & 1 \\
\hline Lotus corniculatus & 32 & 2 \\
\hline Medicago falcata & 1 & 0 \\
\hline Melampyrum pratense & 3 & 0 \\
\hline Mentha type & 1 & 0 \\
\hline Myosotis arvensis & 0 & 1 \\
\hline Onobrychis viciifolia & 6 & 3 \\
\hline Ononis sp & 50 & 6 \\
\hline Plantago lanceolata & 4 & 2 \\
\hline Plantago media & 2 & 2 \\
\hline Potentilla sp & 0 & 10 \\
\hline Primula veris & 1 & 6 \\
\hline Prunella grandiflora & 1 & 0 \\
\hline Pulmonaria sp & 1 & 0 \\
\hline Ranunculus acris & 5 & 6 \\
\hline Ranunculus bulbosus & 6 & 13 \\
\hline Ranunculus repens & 0 & 1 \\
\hline Rumex obtusifolius & 1 & 0 \\
\hline Salvia pratensis & 11 & 1 \\
\hline Sanguisorba minor & 0 & 4 \\
\hline Saxifraga sp & 4 & 3 \\
\hline Scabiosa columbaria & 1 & 1 \\
\hline Senecio sp & 7 & 1 \\
\hline Silene dioica & 1 & 0 \\
\hline Silene vulgaris & 0 & 1 \\
\hline Stellaria holostea & 0 & 5 \\
\hline Taraxacum officinale & 0 & 8 \\
\hline Trifolium pratense & 43 & 3 \\
\hline Trifolium repens & 4 & 1 \\
\hline
\end{tabular}




\begin{tabular}{lrr}
\hline Plant & Bumblebee & Solitary bee \\
\hline Trifolium sp & 5 & 1 \\
Valeriana officinalis & 2 & 0 \\
Veronica austriaca & 1 & 1 \\
Veronica chamaedrys & 5 & 2 \\
Veronica sp & 1 & 0 \\
Vicia sp & 14 & 1 \\
Viola $s p$ & 1 & 0 \\
\hline
\end{tabular}


Table S4. Full and minimum adequate models for network specialization (H2) and network connectance selected with likelihood ratio tests (via “drop1”). Significance levels: ***p<0.001. $* * \mathrm{p}<0.01, * \mathrm{p}<0.05$

\begin{tabular}{|c|c|c|c|c|}
\hline $\begin{array}{c}\text { Response } \\
\text { variable }\end{array}$ & Model & Fixed effects & $\begin{array}{c}\text { LRT } \\
(\mathbf{F})\end{array}$ & $P$ \\
\hline $\begin{array}{l}\mathrm{H} 2 \\
\text { standardized }\end{array}$ & Full & $\begin{array}{l}\text { Network type } \\
\text { Landscape diversity }(350 \mathrm{~m}) \\
(\log ) \text { Fragment area } \\
\text { (log) Connectivity Index }\end{array}$ & $\begin{array}{l}11.25 \\
11.96 \\
0.43 \\
0.12\end{array}$ & $\begin{array}{l}0.0024 * * \\
0.0020 * * \\
0.52 \\
0.73\end{array}$ \\
\hline $\begin{array}{l}\mathrm{H} 2 \\
\text { standardized }\end{array}$ & Min & $\begin{array}{l}\text { Network type } \\
\text { Landscape diversity }(350 \mathrm{~m})\end{array}$ & $\begin{array}{l}11.33 \\
13.58\end{array}$ & $\begin{array}{l}0.0023 * * \\
0.0011 * *\end{array}$ \\
\hline $\begin{array}{l}\text { Connectance } \\
\text { standardized }\end{array}$ & Full & $\begin{array}{l}\text { Network type } \\
\text { Landscape diversity }(200 \mathrm{~m}) \\
(\log ) \text { Fragment area } \\
\text { (log) Connectivity Index }\end{array}$ & $\begin{array}{l}0.99 \\
0.63 \\
1.34 \\
0.55\end{array}$ & $\begin{array}{l}0.33 \\
0.44 \\
0.25 \\
0.47\end{array}$ \\
\hline
\end{tabular}


Table S5. Interactions occurring in both, the visitation and pollen transport datasets

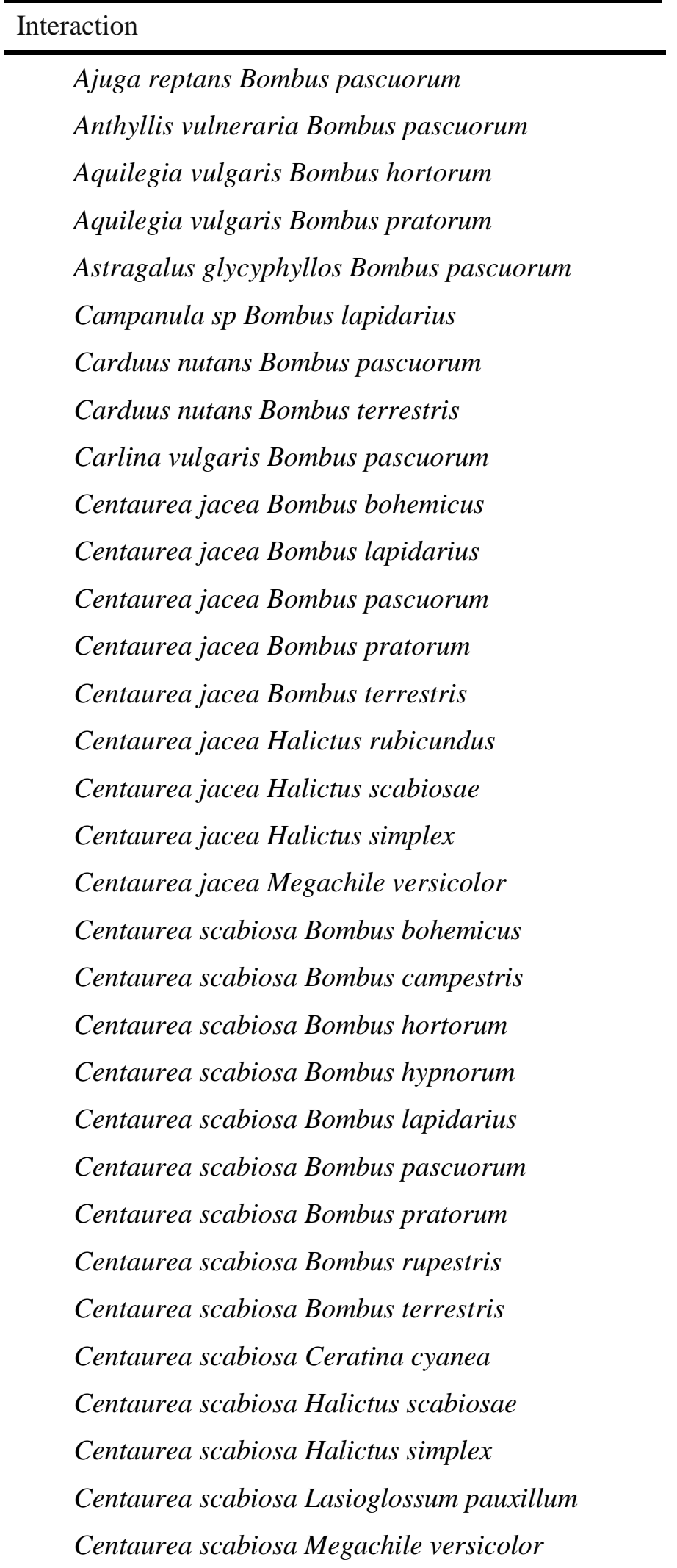


Interaction

Cerinthe minor Bombus pascuorum

Cirsium sp Bombus bohemicus

Cirsium sp Bombus lapidarius

Cirsium sp Bombus pascuorum

Cirsium sp Megachile versicolor

Crepis sp Lasioglossum albipes

Crepis sp Lasioglossum villosulum

Daucus carota Bombus terrestris

Echium vulgare Bombus pascuorum

Fragaria vesca Andrena flavipes

Fragaria vesca Andrena minutuloides

Fragaria vesca Halictus tumulorum

Fragaria vesca Lasioglossum fulvicorne

Fragaria vesca Osmia bicolor

Genista tinctoria Bombus lapidarius

Genista tinctoria Bombus pascuorum

Genista tinctoria Megachile ericetorum

Genista tinctoria Megachile willughbiella

Helianthemum nummularium Bombus pascuorum

Helianthemum nummularium Bombus pratorum

Hieracium cymosum Bombus hortorum

Hieracium pilosella Lasioglossum brevicorne

Hieracium pilosella Lasioglossum leucozonium

Hieracium pilosella Lasioglossum villosulum

Hippocrepis comosa Andrena gravida

Hippocrepis comosa Andrena ovatula

Hippocrepis comosa Andrena similis

Hippocrepis comosa Bombus hortorum

Hippocrepis comosa Bombus lapidarius

Hippocrepis comosa Bombus pascuorum

Hippocrepis comosa Halictus rubicundus

Hippocrepis comosa Megachile ericetorum

Hippocrepis comosa Osmia aurulenta

Hippocrepis comosa Osmia bicolor 
Interaction

Knautia arvensis Bombus bohemicus

Knautia arvensis Bombus campestris

Knautia arvensis Bombus pascuorum

Leucanthemum vulgare Andrena gravida

Lotus corniculatus Bombus lapidarius

Lotus corniculatus Bombus pascuorum

Lotus corniculatus Halictus rubicundus

Medicago falcata Bombus pascuorum

Myosotis arvensis Andrena subopaca

Onobrychis viciifolia Bombus hypnorum

Onobrychis viciifolia Bombus lapidarius

Onobrychis viciifolia Bombus pascuorum

Onobrychis viciifolia Bombus pratorum

Onobrychis viciifolia Bombus terrestris

Onobrychis viciifolia Osmia aurulenta

Onobrychis viciifolia Osmia leucomelana

Ononis sp Anthidium manicatum

Ononis sp Bombus lapidarius

Ononis sp Bombus pascuorum

Ononis sp Bombus terrestris

Ononis sp Megachile versicolor

Plantago lanceolata Bombus terrestris

Plantago lanceolata Lasioglossum pauxillum

Plantago media Bombus pascuorum

Potentilla sp Andrena minutuloides

Potentilla sp Halictus tumulorum

Potentilla sp Osmia bicolor

Primula veris Anthophora plumipes

Primula veris Bombus hortorum

Prunella grandiflora Bombus pascuorum

Ranunculus bulbosus Andrena gravida

Ranunculus bulbosus Andrena strohmella

Ranunculus bulbosus Andrena subopaca

Ranunculus bulbosus Bombus hortorum 
Interaction

Ranunculus bulbosus Chelostoma florisomne

Ranunculus bulbosus Halictus confusus

Ranunculus bulbosus Halictus tumulorum

Ranunculus bulbosus Osmia bicolor

Ranunculus bulbosus Osmia bicornis

Ranunculus repens Osmia bicornis

Salvia pratensis Bombus hortorum

Salvia pratensis Bombus lapidarius

Salvia pratensis Bombus pascuorum

Senecio sp Bombus bohemicus

Silene dioica Bombus bohemicus

Stellaria holostea Nomada flavoguttata

Stellaria holostea Nomada lathburiana

Taraxacum officinale Nomada lathburiana

Taraxacum officinale Osmia bicolor

Trifolium pratense Bombus hortorum

Trifolium pratense Bombus lapidarius

Trifolium pratense Bombus pascuorum

Trifolium repens Bombus pascuorum

Veronica austriaca Bombus hortorum

Veronica austriaca Bombus pratorum

Veronica chamaedrys Andrena labiata

Veronica chamaedrys Andrena subopaca

Veronica chamaedrys Bombus pascuorum

Vicia sp Bombus hortorum

Vicia sp Bombus pascuorum

Vicia sp Bombus pratorum 
Table S6. Interactions exclusive to the pollen transport dataset

Interaction

Ajuga reptans Anthophora plumipes

Anthriscus sylvestris Bombus pascuorum

Anthriscus sylvestris Bombus terrestris

Astragalus glycyphyllos Bombus lapidarius

Campanula sp Bombus terrestris

Campanula sp Megachile ericetorum

Campanula sp Megachile willughbiella

Carlina vulgaris Bombus lapidarius

Centaurea jacea Bombus campestris

Centaurea jacea Lasioglossum costulatum

Centaurea jacobea Bombus bohemicus

Centaurea scabiosa Bombus sylvestris

Cerastium arvense Andrena strohmella

Cerinthe minor Anthophora plumipes

Cirsium sp Bombus campestris

Cotoneaster interregimus Andrena fulva

Crepis sp Andrena flavipes

Crepis sp Bombus lapidarius

Crepis sp Bombus pascuorum

Crepis sp Bombus terrestris

Crepis sp Halictus scabiosae

Crepis sp Halictus simplex

Crepis sp Lasioglossum costulatum

Crepis sp Megachile versicolor

Crepis sp Osmia bicolor

Filipendula vulgaris Megachile willughbiella

Fragaria vesca Andrena strohmella

Fragaria vesca Bombus pascuorum

Galium sp Anthophora plumipes

Galium sp Bombus campestris

Galium sp Bombus pascuorum

Galium sp Bombus terrestris 
Interaction

Geum urbanum Bombus terrestris

Geum urbanum Osmia bicolor

Helianthemum nummularium Bombus hortorum

Helianthemum nummularium Bombus lapidarius

Helianthemum nummularium Osmia aurulenta

Hippocrepis comosa Bombus rupestris

Hippocrepis comosa Osmia leucomelana

Knautia arvensis Bombus hortorum

Lotus corniculatus Bombus rupestris

Melampyrum pratense Bombus pascuorum

Mentha type Bombus lapidarius

Ononis sp Bombus pratorum

Ononis sp Halictus simplex

Plantago lanceolata Bombus campestris

Plantago lanceolata Bombus pascuorum

Plantago lanceolata Bombus rupestris

Plantago lanceolata Megachile willughbiella

Plantago media Bombus pratorum

Plantago media Lasioglossum pauxillum

Potentilla sp Anthophora plumipes

Pulmonaria sp Bombus pascuorum

Ranunculus acris Andrena subopaca

Ranunculus acris Bombus lapidarius

Ranunculus acris Bombus sylvestris

Ranunculus acris Bombus terrestris

Ranunculus acris Halictus tumulorum

Ranunculus acris Osmia bicolor

Ranunculus acris Osmia bicornis

Ranunculus bulbosus Bombus lapidarius

Ranunculus bulbosus Bombus pascuorum

Rumex obtusifolius Bombus hortorum

Salvia pratensis Bombus pratorum

Sanguisorba minor Andrena minutuloides

Sanguisorba minor Anthophora plumipes 
Interaction

Sanguisorba minor Chelostoma florisomne

Sanguisorba minor Osmia bicolor

Saxifraga sp Andrena subopaca

Saxifraga sp Bombus hortorum

Saxifraga sp Bombus pascuorum

Saxifraga sp Bombus pratorum

Saxifraga sp Osmia bicolor

Scabiosa columbaria Andrena gravida

Scabiosa columbaria Bombus rupestris

Senecio sp Bombus campestris

Senecio sp Megachile versicolor

Silene vulgaris Andrena gravida

Stellaria holostea Andrena strohmella

Stellaria holostea Lasioglossum punctatissimum

Taraxacum officinale Anthophora plumipes

Taraxacum officinale Halictus tumulorum

Taraxacum officinale Lasioglossum punctatissimum

Trifolium pratense Andrena gravida

Trifolium pratense Andrena similis

Trifolium pratense Halictus rubicundus

Trifolium repens Bombus lapidarius

Trifolium repens Osmia bicolor

Trifolium sp Andrena ovatula

Trifolium sp Bombus lapidarius

Trifolium sp Bombus pascuorum

Valeriana officinalis Bombus bohemicus

Veronica chamaedrys Bombus hortorum

Veronica sp Bombus terrestris

Viola sp Bombus lapidarius 
Table S7. Interactions exclusive to the visitation dataset

Interaction

Ajuga reptans Bombus hortorum

Alliaria petiolata Lasioglossum calceatum

Anemone sylvestris Bombus pratorum

Anemone sylvestris Bombus terrestris

Anthyllis vulneraria Bombus hortorum

Aquilegia vulgaris Osmia aurulenta

Carlina vulgaris Bombus terrestris

Centaurea jacea Ceratina cyanea

Centaurea jacea Halictus quadricinctus

Centaurea jacea Lasioglossum albipes

Centaurea jacea Lasioglossum calceatum

Centaurea jacea Lasioglossum morio

Centaurea scabiosa Halictus quadricinctus

Centaurea scabiosa Halictus rubicundus

Centaurea scabiosa Hylaeus communis

Centaurea scabiosa Lasioglossum costulatum

Centaurea scabiosa Lasioglossum fulvicorne

Cerastium arvense Bombus pascuorum

Cirsium sp Lasioglossum morio

Cirsium vulgare Bombus bohemicus

Cirsium vulgare Bombus rupestris

Clinopodium acinos Bombus pratorum

Clinopodium vulgare Bombus pascuorum

Cotoneaster integerrimus Andrena fulva

Cotoneaster integerrimus Bombus hypnorum

Cotoneaster integerrimus Bombus pratorum

Crataegus monogyna Andrena chrysosceles

Crataegus monogyna Bombus pratorum

Crataegus monogyna Bombus terrestris

Dactylorhiza fuchsii Bombus pascuorum

Dictamnus albus Bombus pratorum

Euphorbia cyparissias Andrena subopaca 
Interaction

Euphorbia cyparissias Nomada flavoguttata

Filipendula vulgaris Andrena nitida

Fragaria vesca Nomada flavoguttata

Genista tinctoria Bombus terrestris

Genista tinctoria Megachile nigriventris

Geum urbanum Andrena subopaca

Helianthemum nummularium Anthidium punctatum

Hieracium lachenalii Lasioglossum villosulum

Hieracium murorum Bombus bohemicus

Hieracium umbellatum Bombus pascuorum

Hieracium umbellatum Bombus terrestris

Hippocrepis comosa Andrena nigroaenea

Hippocrepis comosa Andrena subopaca

Hippocrepis comosa Anthidium punctatum

Hippocrepis comosa Bombus terrestris

Hippocrepis comosa Lasioglossum punctatissimum

Hippocrepis comosa Megachile nigriventris

Hippocrepis comosa Megachile versicolor

Hippocrepis comosa Megachile willughbiella

Hippocrepis comosa Sphecodes niger

Hypericum perforatum Bombus pascuorum

Hypericum perforatum Bombus terrestris

Knautia arvensis Bombus hypnorum

Knautia arvensis Bombus lapidarius

Knautia arvensis Bombus pratorum

Knautia arvensis Bombus rupestris

Knautia arvensis Bombus sylvestris

Knautia arvensis Bombus terrestris

Knautia arvensis Ceratina cyanea

Knautia arvensis Coelioxys elongata

Knautia arvensis Halictus rubicundus

Knautia arvensis Halictus scabiosae

Knautia arvensis Halictus simplex

Knautia arvensis Lasioglossum albipes 
Interaction

Knautia arvensis Lasioglossum calceatum

Knautia arvensis Lasioglossum morio

Knautia arvensis Lasioglossum pauxillum

Knautia arvensis Megachile versicolor

Lathyrus sylvestris Megachile ericetorum

Leontodon hispidus Anthidium punctatum

Leontodon hispidus Ceratina cyanea

Leucanthemum vulgare Andrena nigroaenea

Leucanthemum vulgare Andrena subopaca

Leucanthemum vulgare Andrena wilkella

Leucanthemum vulgare Bombus hortorum

Leucanthemum vulgare Sphecodes rubicundus

Lotus corniculatus Coelioxys inermis

Lotus corniculatus Halictus tumulorum

Lotus corniculatus Megachile ericetorum

Lotus corniculatus Megachile ligniseca

Medicago lupulina Osmia bicolor

Medicago sativa Bombus pascuorum

Medicago sativa Halictus tumulorum

Melampyrum arvense Bombus hortorum

Myosotis arvensis Bombus pratorum

Ononis sp Anthidium punctatum

Origanum vulgare Halictus rubicundus

Origanum vulgare Halictus tumulorum

Origanum vulgare Lasioglossum morio

Orobanche rapum-genistae Lasioglossum fulvicorne

Polygala comosa Bombus pascuorum

Potentilla sp Lasioglossum pauxillum

Primula veris Andrena nitida

Primula veris Anthophora furcata

Primula veris Bombus pascuorum

Primula veris Lasioglossum pauxillum

Primula veris Osmia bicolor

Prunella grandiflora Bombus hortorum 
Interaction

Ranunculus bulbosus Andrena scotica

Ranunculus bulbosus Lasioglossum pauxillum

Ranunculus bulbosus Nomada flavoguttata

Ranunculus bulbosus Osmia aurulenta

Ranunculus repens Andrena subopaca

Rhinanthus minor Bombus hortorum

Rhinanthus minor Bombus pratorum

Sanguisorba minor Bombus pratorum

Senecio sp Halictus tumulorum

Senecio sp Lasioglossum calceatum

Senecio sp Lasioglossum morio

Taraxacum officinale Eucera nigrescens

Trifolium pratense Bombus bohemicus

Veronica austriaca Andrena labiata

Veronica austriaca Bombus terrestris

Veronica austriaca Hylaeus confusus

Veronica austriaca Osmia bicolor

Veronica chamaedrys Andrena viridescens

Veronica chamaedrys Lasioglossum pauxillum

Veronica chamaedrys Osmia bicolor

Vicia sp Bombus sylvarum

Vicia sp Eucera longicornis

Vicia sp Eucera nigrescens 
Table S8. Richness of flower visitors (Degree) per plant species in the visitation dataset.

\begin{tabular}{|c|c|}
\hline Plant & Degree \\
\hline Ajuga reptans & 2 \\
\hline Alliaria petiolata & 1 \\
\hline Anemone sylvestris & 2 \\
\hline Anthyllis vulneraria & 2 \\
\hline Aquilegia vulgaris & 3 \\
\hline Astragalus glycyphyllos & 1 \\
\hline Campanula sp & 1 \\
\hline Carduus nutans & 2 \\
\hline Carlina vulgaris & 2 \\
\hline Centaurea jacea & 14 \\
\hline Centaurea scabiosa & 19 \\
\hline Cerastium arvense & 1 \\
\hline Cerinthe minor & 1 \\
\hline Cirsium $s p$ & 5 \\
\hline Cirsium vulgare & 2 \\
\hline Clinopodium acinos & 1 \\
\hline Clinopodium vulgare & 1 \\
\hline Cotoneaster integerrimus & 3 \\
\hline Crataegus monogyna & 3 \\
\hline Crepis sp & 2 \\
\hline Dactylorhiza fuchsii & 1 \\
\hline Daucus carota & 1 \\
\hline Dictamnus albus & 1 \\
\hline Echium vulgare & 1 \\
\hline Euphorbia cyparissias & 2 \\
\hline Filipendula vulgaris & 1 \\
\hline Fragaria vesca & 6 \\
\hline Genista tinctoria & 6 \\
\hline Geum urbanum & 1 \\
\hline Helianthemum nummularium & 3 \\
\hline Hieracium cymosum & 1 \\
\hline Hieracium lachenalii & 1 \\
\hline
\end{tabular}




\begin{tabular}{|c|c|}
\hline Plant & Degree \\
\hline Hieracium murorum & 1 \\
\hline Hieracium pilosella & 3 \\
\hline Hieracium umbellatum & 2 \\
\hline Hippocrepis comosa & 19 \\
\hline Hypericum perforatum & 2 \\
\hline Knautia arvensis & 19 \\
\hline Lathyrus sylvestris & 1 \\
\hline Leontodon hispidus & 2 \\
\hline Leucanthemum vulgare & 6 \\
\hline Lotus corniculatus & 7 \\
\hline Medicago falcata & 1 \\
\hline Medicago lupulina & 1 \\
\hline Medicago sativa & 2 \\
\hline Melampyrum arvense & 1 \\
\hline Myosotis arvensis & 2 \\
\hline Onobrychis viciifolia & 7 \\
\hline Ononis sp & 6 \\
\hline Origanum vulgare & 3 \\
\hline Orobanche rapum-genistae & 1 \\
\hline Plantago lanceolata & 2 \\
\hline Plantago media & 1 \\
\hline Polygala comosa & 1 \\
\hline Potentilla sp & 4 \\
\hline Primula veris & 7 \\
\hline Prunella grandiflora & 2 \\
\hline Ranunculus bulbosus & 13 \\
\hline Ranunculus repens & 2 \\
\hline Rhinanthus minor & 2 \\
\hline Salvia pratensis & 3 \\
\hline Sanguisorba minor & 1 \\
\hline Senecio sp & 4 \\
\hline Silene dioica & 1 \\
\hline Stellaria holostea & 2 \\
\hline Taraxacum officinale & 3 \\
\hline
\end{tabular}




\begin{tabular}{lr}
\hline Plant & Degree \\
\hline Trifolium pratense & 4 \\
Trifolium repens & 1 \\
Veronica austriaca & 6 \\
Veronica chamaedrys & 6 \\
Vicia sp & 6 \\
\hline
\end{tabular}


Table S9. Richness of flower visitors (Degree) per plant species in the pollen transport dataset.

\begin{tabular}{|c|c|}
\hline Plant & Degree \\
\hline Ajuga reptans & 2 \\
\hline Anthriscus sylvestris & 2 \\
\hline Anthyllis vulneraria & 1 \\
\hline Aquilegia vulgaris & 2 \\
\hline Astragalus glycyphyllos & 2 \\
\hline Campanula sp & 4 \\
\hline Carduus nutans & 2 \\
\hline Carlina vulgaris & 2 \\
\hline Centaurea jacea & 11 \\
\hline Centaurea jacobea & 1 \\
\hline Centaurea scabiosa & 15 \\
\hline Cerastium arvense & 1 \\
\hline Cerinthe minor & 2 \\
\hline Cirsium sp & 5 \\
\hline Cotoneaster interregimus & 1 \\
\hline Crepis sp & 11 \\
\hline Daucus carota & 1 \\
\hline Echium vulgare & 1 \\
\hline Filipendula vulgaris & 1 \\
\hline Fragaria vesca & 7 \\
\hline Galium sp & 4 \\
\hline Genista tinctoria & 4 \\
\hline Geum urbanum & 2 \\
\hline Helianthemum nummularium & 5 \\
\hline Hieracium cymosum & 1 \\
\hline Hieracium pilosella & 3 \\
\hline Hippocrepis comosa & 12 \\
\hline Knautia arvensis & 4 \\
\hline Leucanthemum vulgare & 1 \\
\hline Lotus corniculatus & 4 \\
\hline Medicago falcata & 1 \\
\hline Melampyrum pratense & 1 \\
\hline
\end{tabular}




\begin{tabular}{|c|c|}
\hline Plant & Degree \\
\hline Mentha type & 1 \\
\hline Myosotis arvensis & 1 \\
\hline Onobrychis viciifolia & 7 \\
\hline Ononis sp & 7 \\
\hline Plantago lanceolata & 6 \\
\hline Plantago media & 3 \\
\hline Potentilla sp & 4 \\
\hline Primula veris & 2 \\
\hline Prunella grandiflora & 1 \\
\hline Pulmonaria sp & 1 \\
\hline Ranunculus acris & 7 \\
\hline Ranunculus bulbosus & 11 \\
\hline Ranunculus repens & 1 \\
\hline Rumex obtusifolius & 1 \\
\hline Salvia pratensis & 4 \\
\hline Sanguisorba minor & 4 \\
\hline Saxifraga sp & 5 \\
\hline Scabiosa columbaria & 2 \\
\hline Senecio $s p$ & 3 \\
\hline Silene dioica & 1 \\
\hline Silene vulgaris & 1 \\
\hline Stellaria holostea & 4 \\
\hline Taraxacum officinale & 5 \\
\hline Trifolium pratense & 6 \\
\hline Trifolium repens & 3 \\
\hline Trifolium $s p$ & 3 \\
\hline Valeriana officinalis & 1 \\
\hline Veronica austriaca & 2 \\
\hline Veronica chamaedrys & 4 \\
\hline Veronica $s p$ & 1 \\
\hline Vicia $s p$ & 3 \\
\hline Viola $s p$ & 1 \\
\hline
\end{tabular}


Table S10. Full and minimum adequate models for unique interactions and unique interactions' proportion in the visitation and pollen transport datasets. Minimum adequate models were selected with likelihood ratio tests (via “drop1”). Significance levels: $* * * p<0.001 . * * \mathrm{p}<0.01$, $* \mathrm{p}<0.05$

\begin{tabular}{|c|c|c|c|c|}
\hline $\begin{array}{c}\text { Response } \\
\text { variable }\end{array}$ & Model & Fixed effects & LRT & $\boldsymbol{P}$ \\
\hline $\begin{array}{l}\text { Unique } \\
\text { interactions }\end{array}$ & $\begin{array}{c}\text { Full } \\
\text { visitation }\end{array}$ & $\begin{array}{l}\text { Landscape diversity }(150 \mathrm{~m}) \\
\text { (log) Fragment area } \\
(\log ) \text { Connectivity Index }\end{array}$ & $\begin{array}{c}4.06 \\
0.11 \\
0.018\end{array}$ & $\begin{array}{l}0.044^{*} \\
0.74 \\
0.89\end{array}$ \\
\hline $\begin{array}{l}\text { Unique } \\
\text { interactions }\end{array}$ & $\begin{array}{c}\text { Min } \\
\text { visitation }\end{array}$ & Landscape diversity (150 m) & 4.59 & $0.032 *$ \\
\hline $\begin{array}{l}\text { Unique } \\
\text { interactions }\end{array}$ & $\begin{array}{c}\text { Full } \\
\text { transport }\end{array}$ & $\begin{array}{l}\text { Landscape diversity }(500 \mathrm{~m}) \\
\text { (log) Fragment area } \\
(\log ) \text { Connectivity Index }\end{array}$ & $\begin{array}{l}4.07 \\
2.35 \\
0.24\end{array}$ & $\begin{array}{c}0.044^{*} \\
0.13 \\
0.62\end{array}$ \\
\hline $\begin{array}{l}\text { Unique } \\
\text { interactions }\end{array}$ & $\begin{array}{c}\text { Min } \\
\text { transport }\end{array}$ & Landscape diversity (500 m) & 5.96 & $0.015^{*}$ \\
\hline $\begin{array}{l}\text { Unique } \\
\text { interactions' } \\
\text { proportion }\end{array}$ & $\begin{array}{c}\text { Full } \\
\text { visitation }\end{array}$ & $\begin{array}{l}\text { Landscape diversity }(150 \mathrm{~m}) \\
(\log ) \text { Fragment area } \\
(\log ) \text { Connectivity Index }\end{array}$ & $\begin{array}{l}0.94 \\
0.38 \\
0.64\end{array}$ & $\begin{array}{l}0.20 \\
0.71 \\
0.53\end{array}$ \\
\hline $\begin{array}{l}\text { Unique } \\
\text { interactions' } \\
\text { proportion }\end{array}$ & $\begin{array}{c}\text { Full } \\
\text { transport }\end{array}$ & $\begin{array}{l}\text { Landscape diversity }(500 \mathrm{~m}) \\
(\log ) \text { Fragment area } \\
(\log ) \text { Connectivity Index }\end{array}$ & $\begin{array}{c}2.79 \\
1.55 \\
0.014\end{array}$ & $\begin{array}{l}0.11 \\
0.22 \\
0.91\end{array}$ \\
\hline $\begin{array}{l}\text { Unique } \\
\text { interactions' } \\
\text { proportion } \\
\end{array}$ & $\begin{array}{c}\text { Min } \\
\text { transport }\end{array}$ & Landscape diversity (500 m) & 5.26 & $0.030^{*}$ \\
\hline
\end{tabular}


a)

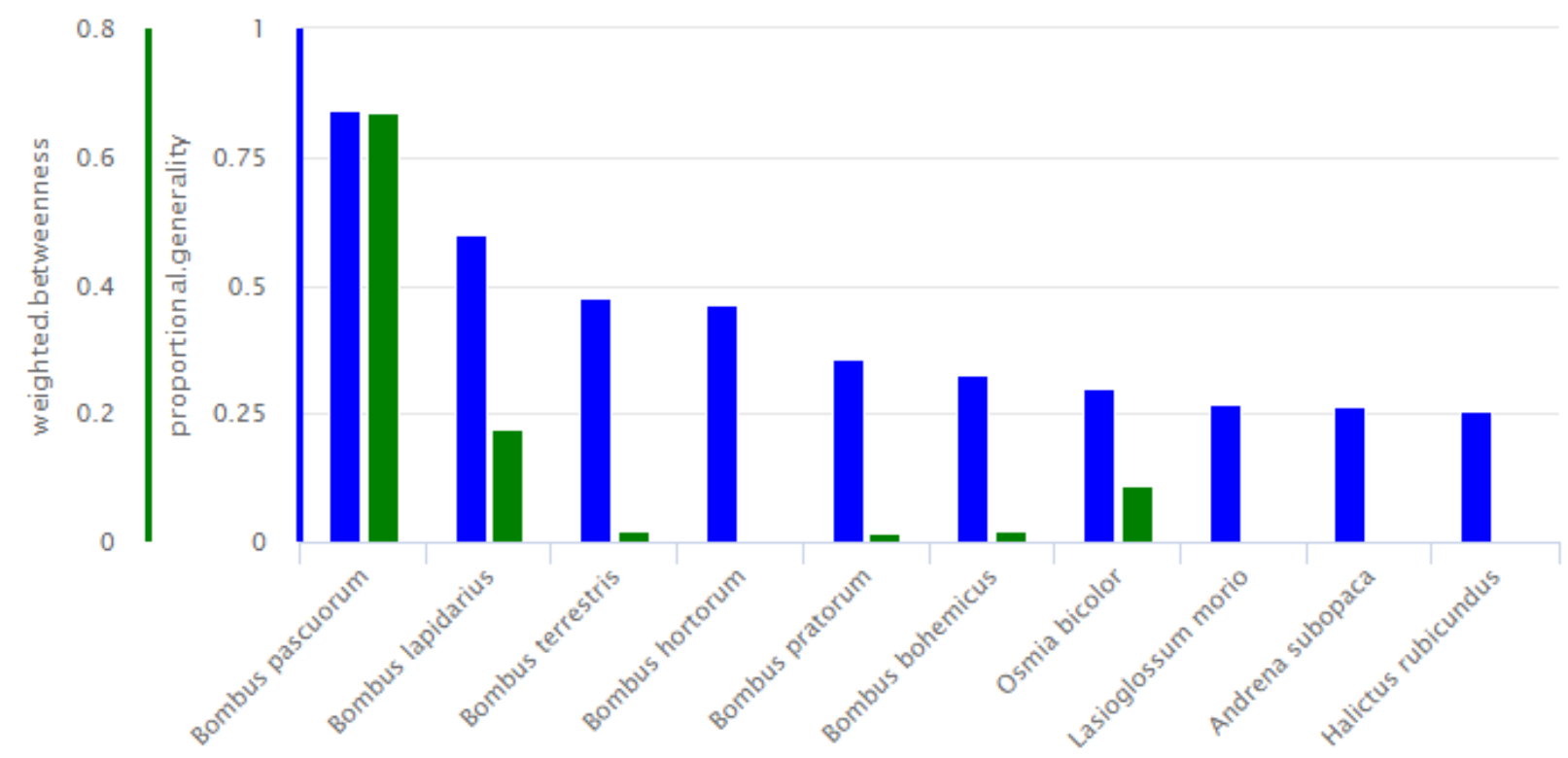

b)

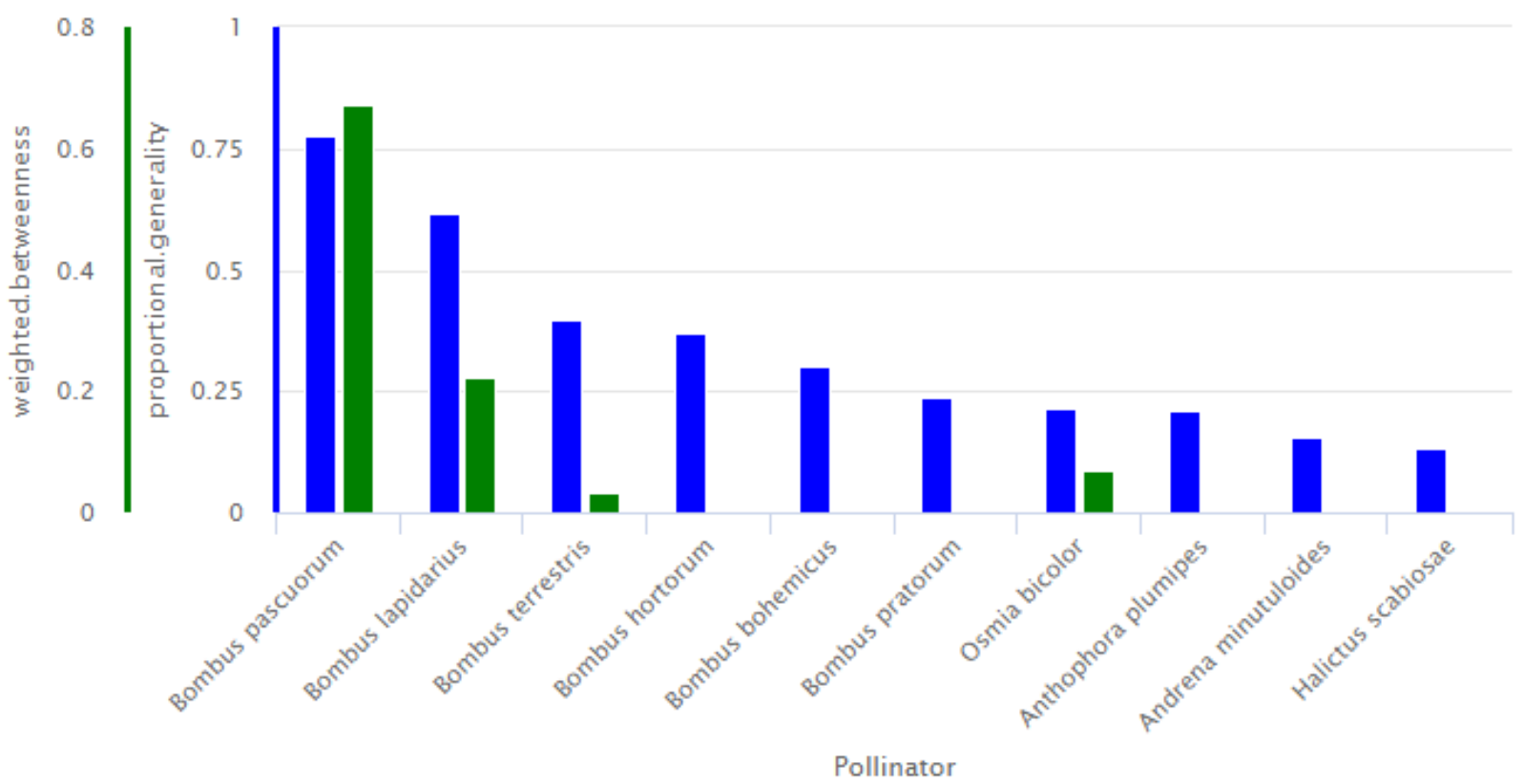

Series 1

Series 2

Figure S1. The 10 most central pollinator species based on proportional generality in a) the visitation metanetwork and $b$ ) the pollen transport metanetwork. 


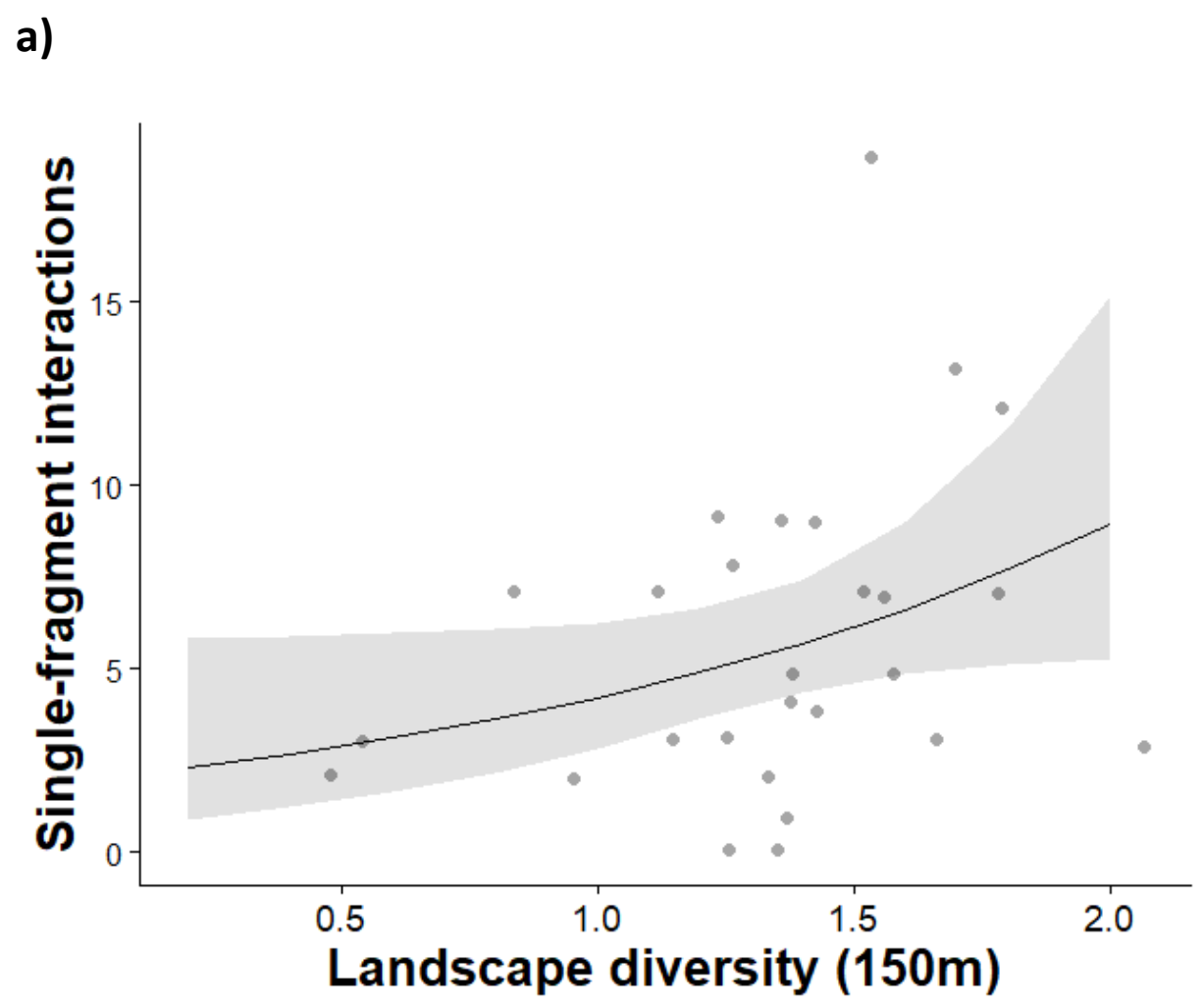

b)

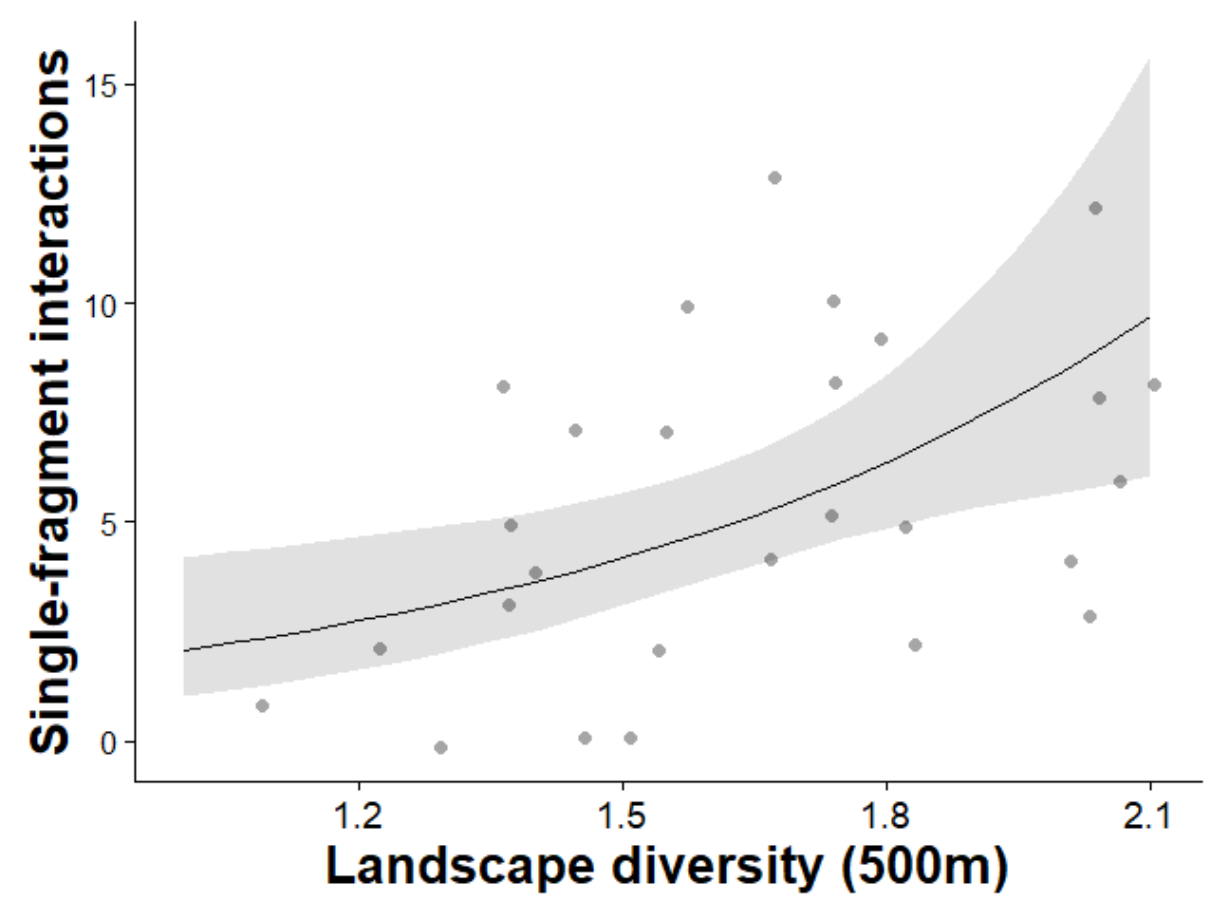

Figure S2. Effect of landscape diversity on the number of single-fragment interactions in local networks in a) the visitation dataset and b) the pollen transport dataset. 


\section{CV}

\section{Felipe Miguel Librán Embid}

\section{Curriculum Vitae}

\section{Personal Details}

Born:

01/03/1989 - Montevideo/ - Uruguay

Nationality: $\quad$ Uruguayan and Spanish

Address: $\quad$ Zoological Biodiversity, Institute of Geobotany, Leibniz University Hannover, Nienburgerstr. 17 30167 Hannover, Germany

E-mail: feliem3@gmail.com

\section{Education}

2016-2020 PhD student in Agricultural Sciences

Georg-August-University Göttingen, Göttingen, Germany

Title: Plant-pollinator networks in fragmented calcareous grasslands.

Supervisor: Prof. Dr. Teja Tscharntke

2013 - $2015 \quad$ Master in Ecology (Mestrado em Ecologia)

Universidade de São Paulo, USP, São Paulo, Brasil

Title: Landscape structure effects on the biological control of the coffee-leaf-miner (Leucoptera coffeella, Lepidoptera: Lyonetiidae) provided by birds and bats.

Supervisor: Prof. Dr. Jean Paul Walter Metzger

2007 - 2011 BSc in Biological Sciences (Licenciatura en Ciencias Biológicas)

Universidad de la República, UdelaR, Montevideo, Uruguay

Title: Reproductive behaviour in Austrolebias affinis, Amato 1986

Supervisor: Dra. Bettina Tassino

\section{Scholarships}

1. Georg-August-University Göttingen

2016-2019 PhD scholarship by the German Science Foundation (DFG)

2. Universidade de São Paulo - USP

2013 - $2015 \quad$ MSc scholarship by the PAEC-OEA-GCUB program

3. Universidad de la República- UdelaR

2010 - $2011 \quad$ Initiation to research scholarship by PEDECIBA (Program for the development of basic sciences)

\section{Field of study}


1. Landscape Ecology/ Ecological networks / Ecosystem Services

\section{Projects}

\section{Research projects}

2016 - $2020 \quad$ Plant-pollinator networks in fragmented calcareous grasslands. Financially supported by the German Research Foundation (DFG) through the RTG 1644-"Scaling problems in statistics".

2013 - $2015 \quad$ Landscape structure effects on the biological control of the coffee-leaf-miner (Leucoptera coffeella) provided by birds and bats.

Financed by the University of São Paulo (USP) and the Foundation for research support of the state of São Paulo (FAPESP)

\section{Personal skills and competences}

Native tongue

\section{1) Spanish / Castilian}

Other languages

European level (*)

2) English

3) Portuguese

4) Italian

5) German

\begin{tabular}{|l|c|c|c|c|c|c|c|c|c|}
\hline \multicolumn{4}{|c|}{ Understanding } & \multicolumn{4}{c|}{ Speaking } & \multicolumn{2}{c|}{ Writing } \\
\hline \multicolumn{2}{|c|}{ Listening } & \multicolumn{2}{|c|}{ Reading } & \multicolumn{2}{c|}{ Spoken interaction } & Spoken production & \multicolumn{2}{c|}{} \\
\hline C2 & Proficient user & C2 & Proficient user & C1 & Proficient user & C2 & Proficient user & C1 & Proficient user \\
\hline C2 & Proficient user & C2 & Proficient user & C2 & Proficient user & C2 & Proficient user & C2 & Proficient user \\
\hline B2 & Independent user & B1 & Independent user & A2 & Basic user & A2 & Basic user & A1 & Basic user \\
\hline B2 & Independent user & B1 & Independent user & B1 & $\begin{array}{c}\text { Independent } \\
\text { user }\end{array}$ & B1 & $\begin{array}{c}\text { Independent } \\
\text { user }\end{array}$ & A2 & Basic user \\
\hline
\end{tabular}

(*) Common European Framework of Reference for Languages - Self-assessment grid

Computer skills $\quad \mathrm{R}$ language, ArcGis, QGis

Other skills Member of the youth $(2006,2007)$ and junior $(2008)$ Uruguayan national handball teams

\section{Relevant graduate courses}

- Ecosystem services and landscape planning - Grade A

- Landscape Ecology, concepts and research methods - Grade A

- Advanced statistical methods in Ecology and Evolution - Score 12/12

\section{Awards}

- $\quad 6^{\text {th }}$ highest GPA of the 2007 biological sciences class (UdelaR, Uruguay).

- Best ecology thesis of 2015 (USP, Brasil).

- "Summa cum laude" grade in PhD dissertation and disputation 


\section{Author Publications}

$\underline{\text { Published in peer reviewed journals }}$

1. LIBRÁN-EMBID, F., DE COSTER, G., METZGER, JP.

Effects of bird and bat exclusion on coffee pest control at multiple spatial scales. Landscape Ecology 32, 1907-1920 (2017). https://doi.org/10.1007/s10980-017-0555-2

2. GRASS, I., LOOS, J., BAENSCH, S., BATÁRY, P., LIBRÁN-EMBID, F., FICICIYAN, A., KLAUS, F., RIECHERS, M., ROSA, J., TIEDE, J., UDY, K., WESTPHAL, C., WURZ, A., TSCHARNTKE, T.

Land-sharing/-sparing connectivity landscapes for ecosystem services and biodiversity conservation. People and Nature 1: 262- 272 (2019). https://doi.org/10.1002/pan3.21

3. METZGER, JP., BUSTAMENTE, M., FERREIRA, J., FERNANDES GW., LIBRÁNEMBID, F., PILLAR, V., PRIST, P., RIBEIRO RODRIGUEZ, R., VIEIRA, IC., OVERBECK, G.

Why Brazil needs its Legal Reserves. Perspectives in Ecology and Conservation, 17(3), 91-103 (2019). https://doi.org/10.1016/j.pecon.2019.07.002

4. LIBRÁN-EMBID, F., KLAUS, F., TSCHARNTKE, T., GRASS, I.

Unmanned aerial vehicles (UAVs) for biodiversity-friendly agricultural landscapes - a systematic review. Science of the total Environment. 732, 139204 (2020). https://doi.org/10.1016/j.scitotenv.2020.139204

\section{$\underline{\text { In preparation }}$}

LIBRÁN-EMBID, F., GRASS, I., GANUZA, C., EMER, C., TSCHARNTKE, T.

A plant-pollinator metanetwork along a habitat fragmentation gradient

LIBRÁN-EMBID, F., GRASS, I., ALARCÓN, V., HERMANN, B., BIAGIONI, S., C., EMER, C., GANUZA, C., HERRERA-KRINGS, C., SETYANINGSIH, CA., TSCHARNTKE, T.

Pollination networks in fragmented landscapes are more specialized for pollen transport than flower visitation 


\section{Acknowledgements}

A $\mathrm{PhD}$ thesis demands years of dedication, perseverance and commitment. Also, as plantpollinator interactions, it makes little sense to be analyzed in isolation. Many people have contributed in this path in direct and indirect ways. Therefore, in the next lines, I will take the liberty of not skimping on words.

My grandmother was a fantastic woman that I had the pleasure to enjoy 19 years of my life. Her name was Esperanza ("hope" in spanish); a name tightly related to what she taught me in life through words and example. One of her most brilliant phrases was "la matemática es la materia más sencilla que hay, el problema es que padece de muy malos profesores... La materia más dificil son las relaciones humanas" (i.e. "math is the easiest subject there is, the problem is that lacks good teachers... The toughest subject are the human relationships"). Coming from one of the first female engineers of Uruguay (graduated in the 1950 class) these words had a special meaning and sticked deeply in my head. As usual, I would confirm the truth behind her words over time.

Indeed, mathematical rules are immutable through space and time and a solid ground to base our hypotheses and knowledge. When these logical rules, patterns and relationships are correctly explained then math becomes easy. Human relationships, on the other hand, are an intrinsic part of the human biology as social beings, that are not possible to solve through mathematical rules. Actually, they involve large amounts of variables, which interact with each other and are abruptly changing in space and time. Furthermore, their solution involves many other areas from the brain not related to mathematical thinking, but to emotion and empathy, among others. Clearly Esperanza was right, differently from the common belief, human relationships are far harder than math.

Human relationships permeate every single aspect of our lives and form complex interaction networks and metanetworks shaping our lives, our happiness and our miseries.

The process of learning and the search of knowledge and understanding has always been the motor os my passion and the main sense of my existence. Learning and knowledge have helped me to overcome challenges from a very young age and to see the beauty in life. 
A very common trait in Latin Americans is our smiling and cheerful mood. In science and in Germany I can see how surprising and misleading that is. A smile and kind treat might be seen as an unnecessary (non-mathematical) trait related to a lack of consciousness on the severity or importance of certain events. Also, it is often unconsciously associated to a low responsibility and seriousness that could impare a person from dealing with tough or complicated situations/problems. All these being very important skills that a scientist and a person should "theoretically" have.

Independently of our cultural differences, humans from all corners of the world need love and support in their lives and most especially during childhood. For many different reasons, love and support are not guaranteed for many Latin American kids. The ghosts of violence, inequality, food scarcity and educational shortages deny a healthy development for most Latin American kids and are abominations that need to be faced and palliated. Those of us who do survive and reach adulthood develop a set of skills that we used to overcome those challenges, namely smiles and kindness. Kindness to the suffering of other human beings and smiles to face the complex and sometimes almost unbearable events in life. Our smiles are the scars of what we have seen and experienced and our choice on how to deal with life in its beauty and misery. Therefore, far from a weakness, is our best skill to face every single challenge no matter how big and complex.

In this huge network of human interactions that we live in, I like to believe that the artificial modularity that has been imposed to us can be overcome. I dream that humanity can be saved by promoting a higher connectance among us and the planet we all share. I hope that through this amazing network, my kindness can spread beyond the limits of my physical frontiers and reach, in remote places, the souls of those in need.

Having said the above I want to give tailored acknowledgements:

My family:

To my grandparents Esperanza and Aurelio for the gifts of love, beauty, intelligence, sensibility and hope that guided me through dark times and were the very reason to keep fighting.

To my mother Eliana for the insipation of math, for being my most loyal fan, for always encouraging me in all my challenges, for believeing in me, for all economic, moral, psicological and logistical support through all my studies. 
To my aunts Alicia and Patricia and to my uncle Rafael for their smiles and kindness. To my brother Josema and my sisters Jamila and Anixe for being amazing and insipiring persons full of love.

To my father, for putting me in contact with sports.

The Agroecology group:

To my dear advisor Prof. Teja Tscharntke. It has been such an inspiration and such an honour to be your student. Only the quality of person that you are surpasses your quality as a researcher. I could not imagine a better place to have done my PhD. I felt outstandingly appreciated, respected and supported through all these almost four years. Thank you so much for all the advice, the teachings, the kindness, the trust and the support you gave me. I really had four of the happiest years of my life here in Germany and you made it possible by not just being who you are but also by forming this amazing human and research group.

To my dear advisor Prof. Ingo Grass. The advice you and Teja gave me was such a perfect balance. Thank you for being always there for me to discuss ideas and answer questions. I felt so much freedom and so much support from you and Teja during this process, I have no words to thank. Also, thanks for selecting me after my interview and to be able to see beyond my smiles, to my potential in research.

To Dr. Carine Emer for all the amazing support, good humor and great discussions. Vc foi um anjo que apareceu do nada para me ajudar! Muuuitíssimo obrigado pelos scripts, as dicas, por me ajudar até final de semana e também me escutar nas horas de dessespero. Não tenho como agradecer!

To Prof. Andreas Schuldt for kindly accepting the invitation to participate in my defense committee. Thank you very much.

To this outstanding research group called Agroecology. It has been so amazing. Still today it is hard for me to believe how lucky I have been to land in this group. Brilliant, inspiring, caring and beautiful people. It has been so much easier with all of you around. You have given me so much help academically and so much joy from our friendships. It has been a true pleasure and honour to come to the office every day to share with you. Thank you! 
Svenja (Bänsch), so kind, helpful and modest. Thanks for helping me from day one (with the sofa $\mathrm{xD})$ until the very last day with the thesis printing. Also for all pollen and bee discussions. Please always keep your extremely kind and lovely personality.

Anoush, also a lovely and sweet person. Thanks for so many phone calls (also Svenja again!) to the doctor and lots of german paperwork. I am so sorry for being such a pain in the... but it was truly helpful. Thanks for the Carnaval experience in Bonn. Great happy memories I will keep forever.

Annika, what a brilliant and low-profile person. Always offering me that big happy smile when knocking your door to ask about bees and other things. Thanks for your kindness in all moments.

Kevin Darras. What a great guy to have around. Smart, always open to help. Fast hands for R. I enjoyed a lot disagreeing with you in stats haha. Thanks for all your help!

Kevin Li. Another great person. So kind and intelligent. You helped me so much in diverse things from English language to GIS stuff. I also enjoyed a lot our philosophical/political discussions. Cheers my friend!

Arne. I mean you three, that office haha. My friend, I really love your personality. Such a chill and funny person. Smart and always cool. Thanks for the super helpful script for landscape metrics in R. Also for the rugby and for coming to our handball games. I hope to keep the friendship for many years.

Felix Klaus. My cool office mate. Junge I had so much fun with you. Great working atmosphere. You are a great person. Funny and relaxed. Those barbecues at your place made a huge difference in the quality of free time here. Great to share the passion for sports with you as well and also for our great discussions in the office. Thanks for never saying "please, just shut up and stop that bullshit" haha.

Nicole, my great salsa and bachata partner. Thank you also a lot for the german language help and for all those moments of joy while dancing.

Caro. Una de mis grandes colegas Latinas! You are such a nice person with such a beautiful smile. Also very intelligent and always there to share a thought and offer your help. Thanks a lot! 
Julia Rosa. What a lovely person you are! Fantastic personality, there is so much love in you. Always taking care of me so nicely. Special thanks for helping me when I locked myself out haha. I still have those great pics!

Manu. Otro de mis capos latinos! What a great personality. Always relaxed and chill and also full of love. Extremely calmed from your voice to your moves. Thanks for inviting us to your place so many times for such great discussions in our informal group meetings. Cheers my friend!

Emmeline. Another lovely and intelligent person. It is so easy to feel good when being around you. You are always kind and nice. Thanks for all the times I asked for your native speaker skills. Fantastic person!

Annemarie. As Julia you always took so much care of me. You are extremely intelligent and take care of everyone. Thanks for all the help you have given me in different issues. Always supportive and kind. Thank you!

Mina. Also a lovely person. Such a nice soul. You also helped me a lot with phonecalls and appoinments. It was great to share with you :;

Felix Kirsch. What a nice shy person you are my friend. Kind, hard worker, always with a smile. You helped me many times with german homework because you were from the "after 5pm" working group together with Nicole haha. Thanks a lot really!

Gabriel. You are obviously a great guy with a great personality and smile. A fantastic last incorporation to the group. I hope you enjoy your $\mathrm{PhD}$ years here as much as I did.

Costanza Geppert. Beautiful person! It was great to have you around and I am very happy about the friendship we built.

Prof. Peter Batáry, thank you for everything Peter! Hajrá ETO!

Hannah and Kristy, you also took good care of me when I arrived. Thank you very much for the bike, the advice and everything.

To Susanne, Brigitte, Mike and Heike also thank you so much! For helping me with paperwork, fieldwork material and all sort of different logistical challenges. So nice with me all the time. My deepest thank. 
To my 2017 fieldwork team and good friends Cristina Ganuza and Guillermo Gallardo Quilacán. I had so much fun with you, it was a great happy experience. Cristina you are such a smart, tenacious, talented young researcher. Also such a nice, funny and kind human being it was a huge pleasure. I learned a lot with you and had a great time! Guillermo you are extremely funny and nice. Such a great fieldmate. Thanks a lot for joining us!

To my 2018 fieldwork team Jessica, Natascha and Svenja. It was great to work with you. Natascha such a responsible and efficient person. Svenja so chill and nice. Jessica also very kind and dedicated. We had great talks about science and more during those lunch breaks. Thanks for all the help you three.

To Celina, Viviana and Julia (Morley) for their great dedication and patience with the pollen analyses. The third chapter would have been impossible without your contributions! Such a nice team. A working environment full of good humor, laughs, smiles and happiness. Great job ladies! And a thousand thanks! Celi also for "los chilaquiles"! Vivi por falar em português comigo e me ajudar a matar a saudade do Brasil!

To Siria Biagioni, Christina Setyaningsih, Prof. Hermann Behling and Lyudmila Shumilovskikh for the help with the pollen analyses and the great tea!

To Leonie and Nadine, hiwis that helped with mapping and pollen analyses. Thank you ladies!

To all my other friends and colleagues in Göttingen and Germany:

To all that came to the fieldwork to help me! Cristina Ganuza, Guillermo Gallardo, Natascha Holube, Jessica Hartinger, Svenja Horstmann, Arne Wenzel, Luigi Saldías, Annika Hass, Ivonne Fabian, Christin Viets, Bettina Donkó, Ashley Lyons, Jacqueline Loos, Emmeline Topp, Costanze Ohlendorf and Julia Morley.

To all the friends and colleagues that read my thesis and gave me valuable feedback. I am extremely thankful to all of you: Carolina, Anoush, Max Hesselbarth, Ben Pelka, Felix, Cristina, Annika, Svenja Bänsch, Kevin Li, Natalia Aristizábal and Annemarie.

To my dear Dörte and Barbara, the secretaries of the RTG 1644. You were so nice and kind all these years. You gave me so much help and advice. Dedicated a lot of time to help me and are so 
nice. I really appreciate all the help from picking me up at the train station to finding me a place to stay. Also with tons of paperwork and answers to so many questions. Infinite thanks!

To Prof. Kerstin Wiegand and Prof. Thomas Kneib for accepting being part of my companion committee and also for being always very nice and polite with me. Also Thomas for the statistical help and teaching and Kerstin for the course on spatial statistics.

To all my good friends in Göttingen. Especially to the Uruguayan (panda) team. Really great people who gave me a feeling of belonging and link to my Uruguayan roots. Thanks to all of you Natalia, Guillermo, Nicolás, Laura, Mattia, Katha, Sofia, Luigi, Virginia and Hernán.

To Luigi Saldías for being there and supporting me in this long path. For all the good moments and food. Gracias Luigin.

Also a special thanks to Christin Viets. My beautiful german teacher. You helped me and taught me so much these years! What a great friendship! I could not express enough how much you helped me. I will be always greatful to you! Gracias profe!

To Liedson Carneiro for encouraging me for this $\mathrm{PhD}$ and for giving me a place to stay when I arrived in Europe. Also for offering me the best he had. Thanks Li! I think you are an awesome person and a great researcher!

To my dear friend Julian Dürk, for hosting me in Frankfurt when I arrived and for the great friendship. To Kevin Darras for also offering me a place to stay in Göttingen when I needed it.

To my RTG friends and colleagues for being a very nice group of people and making every course and activity that we took together an easy and joyful task.

To my tennismates Dr. Torsten Pook and Dr. Max Hesselbarth.

To my handballmates for being so welcoming to the only foreigner in the team. For giving me a place and for so many great sport and beer moments spent together. Also for letting me practice my german. Go Tuspo! 

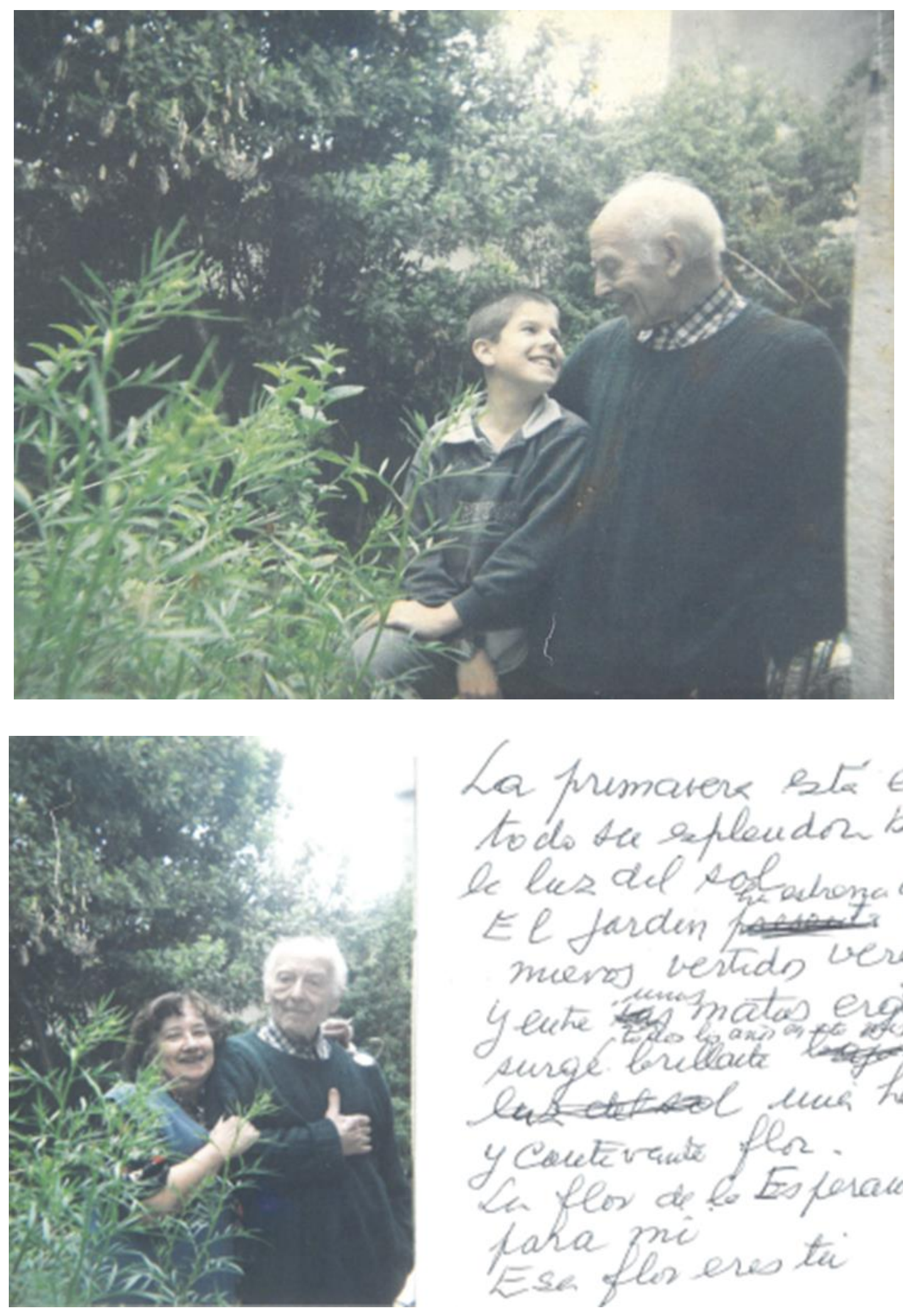

La frumarers está en to do ta sepleudo bullart be lis del Pohtahonado El farden verdas meras vertidn verates Yeute surge loriblacte to lu un hal un hav. y couteraute flor. La flor de Eo Espraurs Eara flor eres tiv 


\section{Declaration}

I hereby declare that I have written this doctoral thesis entitled "Plant-pollinator networks in fragmented calcareous grasslands" independently, that I have not used other sources or facilities other than the ones mentioned, that I have not used unauthorized assistance and that I have not submitted this thesis previously in any form for another degree at any university or institution.

Göttingen, June 2020

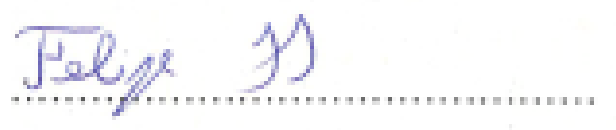

Felipe Librán Embid 